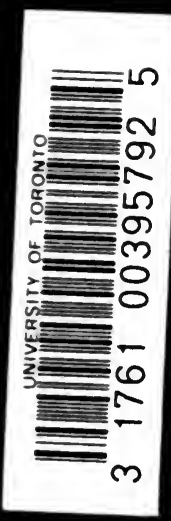




\section{Digitized by the Internet Archive in 2007 with funding from Microsoft Corporation}





\section{JOHN M. WATKINS.}

Publisher

\section{1, Cecil Court, Charing Cross Road, LONDON, W.C.}

The Librarian is respectfully

requested to accept the accompanying volume for the use of the Library in his charge and to kindly acknowledge receipt to the Publisher. 

Pn

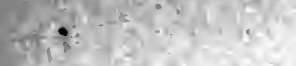

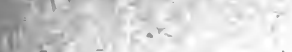

antin?

$=\frac{1}{1}=1$

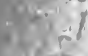

if

1. in.

the

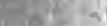

t.te

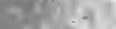

$0+r^{2}=12$

1) 1950.3

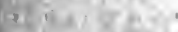

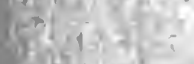

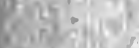

$, x^{2}=0,1,1,03$

dxingy?

Yis

$\operatorname{lin}^{2}, 28 x^{2}$

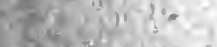

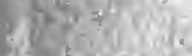

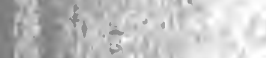

Q

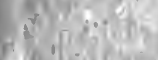

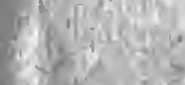

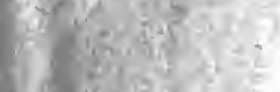

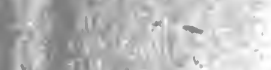

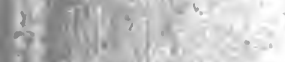

13 (y)

L.T.

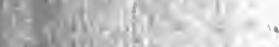

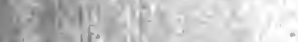

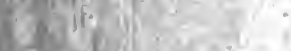

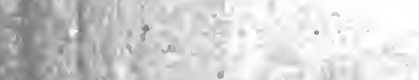

8

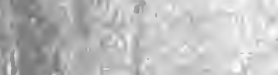

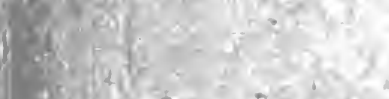

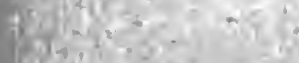

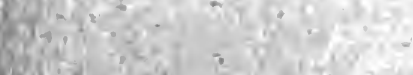

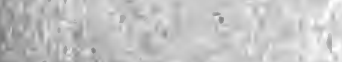

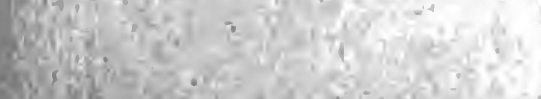

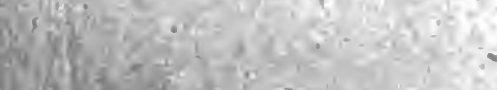

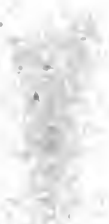

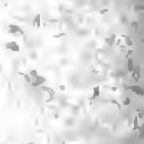

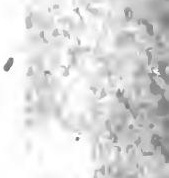

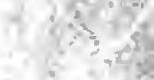

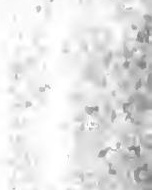

त6 $x^{2}$

$\operatorname{lin}_{10}=$

$-9^{2}-0^{2}$

त्री है

sis. 4

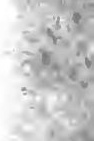

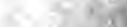

$\because x+4$

,

$-2+2$

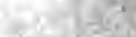

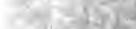

inkas?

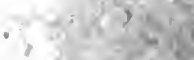

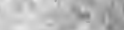

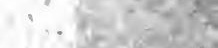

$10=28030 \%$

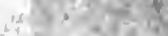

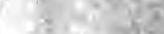

$+i^{2}+4 x^{2}+2$

$(3,-16,010$

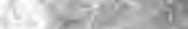

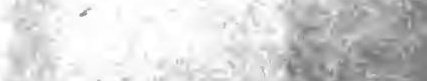

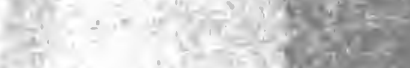

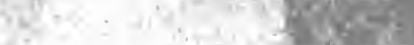

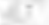

$\frac{4}{4}+x^{2}=$

$\because 4$.

$9-x^{2} a 58$

Axas

ingtis

जो

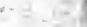

$2 \frac{2}{2} \sin x$

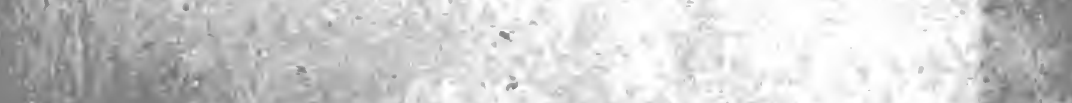





\section{THE PERFECT WAY;}

OR,

THE FINDING OF CHRIST. 



\section{Presuntation, Edition.}

\section{THE PERFECT WAY;}

OR,

\section{THE FINDING OF CHRIST.}

BY

ANNA (BONUS) KINGSFORD

(M.D. OF THE FACULTY OF PARIS)

AND

EDWARD MAITLAND

(B.A. Cantab.).

FOURTH EDITION, WITH ADDITIONS.

With a Preface by SAMUEL HOPGOOD HART.

\&ondorr:

JOHN M. WATKINS,

$2 I$ CECIL COURT, CHARING CROSS ROAD.

ALL RIGHTS RESERVED.

1909.

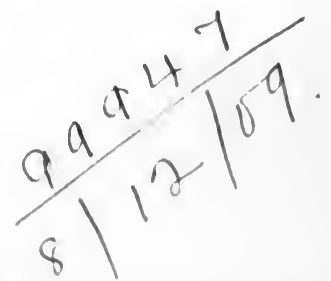




\section{JANE (MILLER) FISHER}

\section{Presentation Edition}




\section{PREFACE TO THE FOURTH EDITION.}

"Make me to know the way wherein I should walk: for to Thee have I lifted up my soul. . . .

"Thy good Spirit shall lead me into the right land."-PSALM cxliii. 8, 10.

"I will give thee understanding, and will instruct thee in the way wherein thou shalt go."-PSALM xxxii. 9.

"He that walketh in a perfect way, he shall serve Me."-PSALM ci. 6 .

"Be ye therefore perfect."-MAтT. v. 48.

THE nine lectures which constituted the First Edition of this book were delivered by Anna Kingsford and Edward Maitland before a private audience, in the months of May, June and July, I88I : and were published anonymously, under the title of The Perfect Way; or, The Finding of Christ, in the following winter.

They represent, as the full title of the book denotes, the doctrine that by "Christ" is designated neither a person merely historical nor one supernatural : but the type of the highest possibilities of humanity, the summit of the ladder of evolution where "the manhood" is taken "unto God," and man melts into, and blends with, and becomes one 
with Divinity, and "God and Man is one Christ ": ${ }^{1}$ for the attainment of the Divine Union-which alone constitutes perfection-is open to all persons. And they represent this supreme point of perfection as attainable through, and only through, the following of a perfect ideal of life in all things appertaining to Man in each department of his fourfold nature, namely, in body, mind, soul and spirit. This great truth is symbolised by the Catholic Church in the Mass, when the Priest mixes a little Water-representing Humanity -with the Wine-representing Divinity -in the Chalice, the Water having been previously sanctified and so made worthy to be taken up and lost in the substance of the Wine about to be consecrated; the Priest at the same time praying on behalf of himself and of the congregation that by the mystery represented by this Water and Wine they may be made partakers of the Divinity of Jesus Christ who vouchsafed to become partaker of our Humanity.

The Perfect Way was "designed to exhibit the process of the interior perfectionment of the individual-the process, that is, whereby 'Christ' becomes 'Christ' - and thereby to interpret the Christ : it did not come within the scope of this book to elaborate the various practical applications of its doctrine, if only for the reason that, when once the spirit of the man is perfected, conduct will order itself accordingly." 2 But two practical applications are emphasised, namely, as regards Vegetarianism and Vivisection. "The former is insisted on as essential to the full apprehension and realisation of

1 Creed of St. Athanasius. See also App. No. III.

2 E. M., letter to Literary Guide, 15th October, 1890. 
the ideal implied by the term 'Christ' - among other reasons for its sensitising influence on the higher planes of the consciousness : and the latter is unsparingly denounced as constituting a total repudiation of that ideal by its suppression of the higher self in favour of the lower as the rule of conduct." 3 For-

"There is a path which no bird of prey knoweth, And which the vulture's eye hath not seen :

The lion's whelps have not trodden it, Nor the fierce lion passed by it." 4

The Perfect Way represents and is the product of a Divine Revelation: a Revelation in the direction of Mysticism : a Revelation which has restored to the World "that famous system of cosmogony which-known to initiates as the Hermetic Gnosis-has from the remotest antiquity been venerated as the one true divine revelation concerning the nature of man and the universe; and which constituted the core and substance of all sacred scriptures, mysteries, and religions - Brahminism and Buddhism, Zoroastrianism, Osirisism, Mithraism, Hellenism, Judaism and Christianity, being in turn designed as vehicles for and expressions of it ; but in each of which its true meaning became perverted, obscured, and finally lost to view behind the forms in which it was presented, and the religion degraded into an idolatry through the substitution, as the objects of worship, of its material symbols for its spiritual realities." And it represents a discovery of "the interpretation of these forms -together with the spiritual facts to which they correspond

${ }^{3}$ E. M., letter to Lilerary Guide, 15 th October, 1890.

- Job xxviii. 7, 8. 
- to the full explication of Christianity, its identification with the Gnosis, and, consequently, its vindication as constituting, when rightly apprehended, a true science of divine things, and therein a perfect system of thought and rule of life." 5 It claims thus to be "both Christian and Catholic in their original and true sense." 6 In fact, the Gnosis finds "its fullest and most perfect formulation by the mouth and in the dogmas of the Catholic Church." 7 "The Initiate has no quarrel with the true Christian religion or with its symbolism, but only with the current orthodox interpretation of that religion and symbolism." 8

"The Gnosis, while in the world, has never" (prior to the publication of The Perfect Way) "really been given to the world, or presented under a form which would render it comprehensible by the world, but has been reserved for initiates pledged to secrecy, and concealed under symbols to the interpretation of which they alone had the key. It is in part because this key has been lost, or so carefully concealed as to be no longer available-even for initiates themselves, as would appear to be the case-and because only by a new illumination could it be restored," that such a Revelation became necessary. ${ }^{9}$

In a recently published book, a well-known writer says

5 E. M.'s MS., preface to an American edition of $P . W$.

'Lect I., 42.

7 A. K.'s MS., "Les Rois Mages Mystiques."

${ }^{8}$ A. K., letter to President of T.S. (Madras), 3ist October, 1883 ; and see C.W.S., p. 198, n. (5).

${ }^{9}$ E. M.'s MS., preface to an American edition of $P . W$. ; and see Lect. II., 12 ; VII., 49. 
that "the great need of to-day" is "a complete reformation in Christian interpretation, a re-casting of popular exegesis, a re-moulding of Christian teaching in pulpit, school, and college." 10 More than twenty years ago, Anna Kingsford expressed a similar opinion; she said: "It is not so much the revelation of a new religious system that is needed here, as a true interpretation of the religion now existing." 11 The revelation contained in the pages of The Perfect Way supplies this great need of a true interpretation of the Christian religion. It was given for the express purpose of rescuing religion from the perversion it had undergone at the hands of a materialising priesthood, by interpreting it, and re-establishing it as a verity purely spiritual and wholly reasonable, and so carrying on the spiritual consciousness of the race to a new and higher stage of its evolution. " "The end in view is not denial, but interpretation; not destruction, but reconstruction, and this with the very materials hitherto in use." 18 No new Gospel of Salvation was necessary or possible, but a new Gospel of Interpretation was indispensable.

In her Presidential Address to the British Theosophical Society, on the I 7 th July, I883, Anna Kingsford said: "We proffer an Eirenicon to all Churches, claiming, that once the veil of symbolism is lifted from the divine face of Truth, all Churches are akin, and the basic doctrine of all is identical

${ }^{10}$ Deep Breathing, by Arthur Lovell, p. 28.

"Letter to President of T.S. (Madras), 31 1 st October, 1883 ; see also App. No. III.

${ }^{12}$ E. M., letter to R., 3rd May, 1891 ; and see Lect. 11., 44.

${ }^{13}$ Lect. I., 56. 
Roc sins. Greek, Hermetic, Buddhist, Vedantist, ${ }^{14}$ Christianall these Lodges of the Mysteries are fundamentally one and identical in doctrine. . . . We hold that no single ecclesiastical creed is comprehensible by itself alone, uninterpreted by its predecessors and its contemporaries. Students, for example, of Christian theology will only learn to understand and to appreciate the true value and significance of the symbols familiar to them, by the study of Eastern Philosophy and Pagan Idealism. For Christianity is the heir of these, and she draws her best blood from their veins. And, forasmuch as all her great ancestors hid beneath their exoteric formulas and rites-themselves mere husks and shells to amuse the simple-minded-the esoteric or concealed verities reserved for the initiate, so also she reserves for earnest seekers and deep thinkers the true interior Mysteries which are one and eternal in all creeds and Churches from the foundation of the world. This true, interior, transcendental meaning is the Real Presence, veiled in the elements of the Divine Sacrament : the mystical Substance and Truth figured beneath the Bread and the Wine of the ancient Bacchic orgies, and now of our own Catholic Church. To the unwise, the unthinking, the superstitious, the gross elements are the objects of the rite; to the initiate, the seer, the son of Hermes, they are but the outward and visible signs of

14 A careful and an erudite student of the Hindu Scriptures said that The Perfect Way contained "passages identical with some which he had rendered from the Upanishads, but of which no translation had ever been published; and he accounted for the coincidence by supposing an identical illumination for both" (Life of $A$. K., vol. ii., p. 287).

$$
\begin{aligned}
& \text { a identicil with scythes, sumerians, } \\
& \text { urs, Parths, Goms, Sormates, Arians "Etroosto } \\
& \text { Achueans, }
\end{aligned}
$$


that which is ever and of necessity, inward, spiritual, and occult." 15

The line of thought introduced by The Perfect Way, therefore, "is not more friendly to the popular presentation of orthodox Church doctrine than to the fashionable agnosticism of the hour. It represents, indeed, a revolt against all conventional forms of belief, whether ecclesiastical or secular, and a conviction that the rehabilitation of religion on reasonable and scientific grounds is not only possible to the human mind, but is essential to human progress and development." 16 "Of one thing," said Anna Kingsford, "I am sure, and that is, that there is not, and cannot be, any half-way house between Atheism and that doctrine which I have." 17

It is necessary to understand what is meant by "Mysticism " and "Mystics." In its true sense, "Mystery" denotes, not something that transcends and contradicts reason and exalts authority in the place of understanding, but that which, being interior, hidden, and spiritual, requires the application of reason to a higher plane than the exterior, phenomenal, and sensible. ${ }^{18}$ Mysticism is Substantialism, and is the opposite to Materialism. The true plane of religious belief is subjective and spiritual, not objective and physical. Mystics speak from within, which implies

${ }^{18}$ Life of $A$. $K$, vol. ii., p. 125.

${ }^{16}$ A. K., letter in Pall Mall Garelte, 1884. See Life of A. K., vol. ii., p. 185 , and Lect. I., 12.

${ }^{17}$ A. K., Diary, 13th November, 1881. See Life of $A$. K., vol. ii., p. 40.

18 E. M., letter in Light, 1892, p. 620. 
experience; not, as do the multitudes, from without, as spectators merely. Mystics are "those who, in virtue of their own spiritual maturity and development, have been enabled to transcend the outer and lower spheres of the consciousness, the material and the astral, and to attain to the inner and upper, the kingdom within of the soul and spirit, and who are able, therefore, to discern the principles of things, where others can discern things only, and thus know the realities of which things are the appearance." 19 "I have heard of Thee by the hearing of the ear; but now mine eye seeth Thee," said pious Job: ${ }^{20}$ and it was as a Mystic that David spoke, when he said: "The uncertain and hidden things of Thy wisdom Thou hast made manifest unto me." 21

From the foregoing, it will be seen that Mysticism has been correctly defined as "experiential Theosophy." While Theosophy, "in its broader signification, represents and includes the entire range of Transcendentalism, the Science of the Mystic is strictly and finely spiritual. It is the science of the Saint rather than of the Adept, and occupies itself immediately and concentratively with the interests of the Soul, and the aspirations of the Heart. It takes scant account of occult physics and dynamics, or of the intellectual ceremonials of la Haute Magie. In intent and scope, it is interpretative rather than exegetic or constructive, and occupies itself with the conversion of the exoteric, material, and general formulæ of faith and doctrine into esoteric,

19 E. M., letter in Light, 1894, p. 477; and see Lect. V., 29.
20 Job xlii. 5 .
${ }^{21}$ Psalm 1. 7. 
spiritual, and particular meanings, enfranchising the concerns and interests of the Soul from the bondage of the Letter and the Form, and lifting the plane of belief from the level of Tradition to that of Revelation. Thus the religion of the Mystic is essentially spiritual, and all its articles relate to interior conditions, principles, and processes. It is based upon experimental knowledge, not on authority, and its central figures are attributes, qualities, and sacraments (mysteries), not persons nor events, however great or remarkable. These latter, with all the material accessories and accidents they imply, are by the Mystic regarded as constituting the Vehicle, not the essential element of religion, since they are not, and cannot be noumenal or absolutes." 22

Just as there were many who saw no necessity for the further unfoldment of the spiritual consciousness represented by Christianity, and resented the introduction of that religion; so there are, and must be, many who similarly object to the further unfoldment of Christianity, represented by a movement in the direction of Mysticism. ${ }^{23}$ It is necessary, therefore, again to emphasise the fact that this book of "the Mysteries of the Kingdom of God" was written for the "educated and developed," rather than for the uninstructed and undeveloped. ${ }^{24}$ It was "not written for those who are so well content with what they already have of divine knowledges, as to desire no more;" but it was "written for those who thirst after such knowledges,

${ }^{2}$ A. K.'s MS., "Les Rois Mages Mystiq̨ues," and A. K., letter to President of T.S. (Madras), 3 ist October, 1883 .

${ }^{2}$ E. M., letter to J. S. C., 28th April, 1890.

24 Pref. R.E., p. lviii. post. 
and desire to obey the injunction-so incessantly enforced in Scripture- 'with all thy getting get Understanding'; for that which this work does, as never before has been done in respect of Christianity, is to relate the things of the Soul to the Mind in such way as to replace and establish religion on its proper 'rock,' the Understanding, instead of resting it on the authority of an Order, such as the Sacerdotal." 25 In her Presidential Address to the British Theosophical Society, before referred to, Anna Kingsford also said: "Ours may be indeed the religion of the poor, but it cannot be that of the ignorant. For we disclaim alike authority and dogma, we appeal to the reason of humanity, and to educated and cultivated thought. Our system of doctrine does not rest upon a remote past ; it is built upon no series of historical events assailable by modern criticism; it deals not with extraneous personalities or with arbitrary statements of dates, facts, and evidence ; but it relates, instead, to the living to-day, and to the ever-present testimony of nature, of science, of thought, and of intuition. That which is exoteric and extraneous is the evanescent type, the historical ideal, the symbol, the form, and these are all in all to the unlearned. But that which is esoteric and interior is the permanent verity, the essential meaning, the thing signified; and to apprehend this, the mind must be reasonable and philosophic, and its method must be scientific and eclectic." 26

"I rarely," said Edward Maitland, "see any question ${ }^{26}$ E. M., letter to J. S. C., 28th April, 1890.

${ }^{26} L$ Life of $A$. $K$., vol. ii., p. 126. See also App. No. III. 
raised which, for those who are spiritually intelligent, has not been adequately treated in The Perfect Way." ${ }^{27}$ It is "especially valuable for the genuine student of things spiritual, because, instead of representing foregone conclusions mechanically adopted or hastily formed, or conclusions rested on a narrow range of observation, or consisting of mere speculations and theories, or being a compilation of the opinions of others, it represents the actual experiences, perceptions, and recollections of its own writers, concerning orders of beings and spheres of activity at once including and transcending those familiar to Spiritualists, while its conclusions have the further advantage of coinciding with and receiving confirmation from those of the most advanced souls known to our planet, whether as formulated in the sacred mysteries of antiquity, or as since discerned by all who have, by 'living the life,' specially qualified themselves to be instruments of spiritual perception." 28

In the Preface to the Second Edition, reference is made to certain "experiences" of which this book is the result. Since the publication of that Edition, Edward Maitland has related (shortly), in The Story of the New Gospel of Interpretation, ${ }^{29}$ and (fully) in his great and final work, The Life of Anna Kingsford, ${ }^{30}$ these experiences, and the following facts are derived mainly from these sources. In telling the tale

2 Letter in Light, 1890, p. 494.

28 Jbid., p. 507.

29 Published in 1893. A third and enlarged Edition was published in 1905, under the title of The Story of Anna Kingsford and Edward Mailland, and of the New Gospel of Interpretation.

so Published, in two large volumes of 880 pages, in 1896 . 
of The Perfect Way, I have endeavoured as far as possible -and even at the risk of some repetition-to tell it in the words of the participants, so as to give to this Preface the additional value that must attach to ipsissima verba.

The collaboration between the late Anna Kingsford and Edward Maitland, of which this book was the chief outcome ${ }^{31}$ may be said to have commenced in February, 1874 , when Edward Maitland first visited Anna Kingsford at her husband's rectory at Pontesbury, Salop (Shropshire), for a fuller interchange of ideas than could otherwise have been had. This memorable visit, which lasted for nearly a fortnight, resulted, said Edward Maitland, "in an intimacy which made me to such extent a member of the family as to remove all obstacles to the collaboration required of us." 32 The purpose of this collaboration proved to be the restoration of the esoteric philosophy or Theosophy of the West, and the interpretation thereby of the Christian and kindred religions. ${ }^{33}$ Both were conscious of a mission, and when the time came for the "unsealing of the World's Bibles," they recognised their "own appointed mission as that of unsealing the Bibles of the West": ${ }^{34}$ a mission derived, not from any Church or a section of any Church visible, terrestrial, and corrupt, but "from the Church invisible, celestial, and incorruptible." 35 Prior to the publication of The Perfect Way, there was not any

${ }^{31}$ Life of $A . K$., vol. i., p. 108.

${ }^{2}$ Story of $A . K$. and $E$. M., pp. I, 2, 37.

${ }^{33}$ Life of $A$. $K$., vol, ii., p. 15 .

${ }^{34}$ Story of $A . K$. and $E . M$., pp. 2, 15, 16, 37; Life of $A . K$., vol. ii., p. 20.

${ }^{35}$ Life of $A . K .$, vol. ii., p. 286. 
satisfactory work in existence enunciatory of the true spiritual interpretation of the allegories of the Bible. ${ }^{36}$

It is a remarkable fact that, precisely at the moment when Anna Kingsford and Edward Maitland were entering upon the collaboration which had for its aim the restoration, interpretation, and vindication of the great mystical system of the West which underlay all its ancient religions and sacred Scriptures, the founders of the Theosophical Society were preparing, on the other side of the Atlantic, to do precisely the same thing for the corresponding system of the East; and it is remarkable that the whole movement comprising these two events, had its rise precisely at the time for which it had been announced in numerous predictions from before the Christian Era to the latter Middle Age, and partook of precisely the characteristics then prescribed. ${ }^{37}$

36 "The difference," said Edward Maitland, " between this book and others kindred to it, is that while they, one and all, whether anterior or posterior to it, content themselves with interpretations which are not purely spiritual and therefore not mystical, The Perfect Way insists on the purely spiritual as alone representing the intention of the allegories in question" (Light, 1888, p. 474); and, he said, "it is only the interpretation that $I$ am giving that will save the Bible and at the same time abolish the supposed antagonism between religion and science" (Letter to R., 3rd May, 1891).

37 Life of $A . K$., vol. ii., pp. 15, 16. See Article of E. M. in Light, 1890, p. 522. While this was so, The Perfect Way is the outcome of a work that was commenced prior to the formation of the Theosophical Society, which was formed towards the close of 1875 , and carried out in complete independence of that Society and its teaching. Any similarity between the teaching must be ascribed to the correspondence originally subsisting between the Christian and Buddhist religions.

On the arrival of The Perfert Way in India, in the Spring of 1852 , the chief of the Theosophical Society invited Anna Kingsford and 
Their method of procedure consisted in "the forcible projection of their mind's perceptive point inwards and upwards to its central and radiant point in search of the informing idea of any phenomenal fact, following meanwhile the mode of life which always has been found essential to such intro-vision, one indispensable condition being the renunciation of flesh as food." 38 The inward and upward direction of the mind, and the knowledges thereby received, constitute the Intuition, which faculty, Edward Maitland said, "consists in such polarisation-by means of intense concentration - of the consciousness to its innermost and highest point, as brings the man into open relations with his central, essential, permanent ego, the Soul, and makes him a participator in the knowledges concerning God and

Edward Maitland to join that Society in the capacity of President and Vice-President respectively of their British Branch, saying that "they recognised in that book knowledges of which the Eastern Adepts had believed themselves to be the exclusive possessors, having been safeguarded by them from the remotest ages " (Letter of E. M. in Light, 1893, p. 104, and see App. No. III.): and in January 1883, Anna Kingsford and Edward Maitland, on the nomination of C. C. Massey, were elected President and Vice-President respectively of the British Theosophical Society; but, in $\mathbf{1 8 8 4}$, owing to the opposition from certain Members of that Society (then known as the London Lodge of the Theosophical Society) to their introduction of Christian Theosophy, they withdrew from the Lodge, and sought an independent platform for their teaching in the Hermetic Society, which they then formed. This Society, owing to the ill-health of Anna Kingsford, after two years fell into abeyance. Happily, owing to the subsequent change of attitude on the part of the Theosophical Society, the causes which forced Anna Kingsford and Edward Maitland to withdraw from the London Lodge have long ceased to exist.

${ }^{88}$ E. M., Letter in Light, 1893, p. 103 ; and see C.W.S., Pref., p. xxii. 
the universe which, in the long ages of its past as an individuated entity, the Soul has acquired by experience. This condition constitutes for the subject of it Spiritual Illumination, and its products are Divine Knowledges." 39

In 1876 , Edward Maitland was writing a book having for its text and title The Finding of Christ, the Completion of the Intuition, and the Restoration of the Ideal. "This Book," Edward Maitland said, "I was allowed neither to complete nor yet to abandon. Through some compulsion, the source and reason of which $I$ was at the time unable to discern, the writing of it was suspended; but only-as the event proved-to be resumed, in another form, after the course of education, experience, and unfoldment necessary for its due accomplishment." 40

Two years later, he had "written enough to make a moderate volume," defining the principles on which, as it appeared to him, the Bible, in order to be a book of the Soul, must be constructed, and on which, therefore, it must be interpreted.41 But, though he had consciously been assisted in his work by light from interior sources, the book was still incomplete, and he had come to a standstill, being " unable to obtain a glimmer of a fresh idea." 42 He had no books to help him, nor the knowledge of any which could help him. He did not speak of the direction of his thought, or of his difficulties to Anna Kingsford (with whom he was then staying in Paris), partly because he wished to exhaust

${ }^{30}$ See further as to this, C.W.S., Pref, , pp. xxi. to xxvi.

to Life of $A$. $K$., vol. i., pp. 100, 101.

1 Ibid., p. 264.

- 1bid., p. 265. E. M., article in Light, 1888, p. 127. 
his own resources first, partly because he did not wish to take her mind off her medical studies in which she was then engrossed, ${ }^{43}$ and partly because he knew that, unaided by illumination, she could not help him; and, at that time, she had not received any special illumination for many months. ${ }^{44}$

In this state of affairs, Edward Maitland said: "It was near midnight on June 4 th, 1878 , when, having retired to my sleeping-room, I stood by the open window gazing on the brilliantly starred sky, and the impulse came upon me to address a mental request for aid to the unseen agents of our past illuminations, whom we were wont to call the Gods. It was without any definite idea of a practical result that I did this, and rather as an expression of impatience and despair than of hope. 'If I really am to carry on this work, I must have help. I have gone as far as I can go of myself, and must stop and give it up unless $I$ receive correction, confirmation, or extension. For my own resources are exhausted.' Having thus silently formulated my needs to the rulers of the starlit expanse, I went to bed." 45 Two mornings after this, Anna Kingsford, not knowing anything of Edward Maitland's request, handed him a manuscript, containing about 860 words, written in pencil, saying it was something she had seen in her sleep during the night and written down immediately on waking, so far as she could recollect it ; and she wanted to know if it was anything that

43 Anna Kingsford was then on the eve of a very important examination.

"t Life of $A . K$., vol. i., p. 265.

45 Ibid., pp. 265, 266. 
he wanted-for she hardly knew what it was about, having written it so rapidly, and not having had time to read it over and think about it. "Eagerly perusing it," Edward Maitland said, "I found it to be a direct answer to my appeal, which for fullness and lucidity surpassed the most sanguine expectations I could have formed, and affording at once precisely the correction, the confirmation, and the amplification I had asked for." 46 They read and re-read it with amazement and delight, and found that it opened the Scriptures from one end to the other, relating Genesis to the Apocalypse, and giving a key to the interpretation of both, but, to their disappointment, the communication was incomplete, leaving off in the middle of a sentence. Anna Kingsford then told Edward Maitland that she had received this communication under the following circumstances: she had dreamt that she was in an old-fashioned library, in which sat an elderly couple, at whose invitation she mounted a ladder and took down a book the appearance of which had attracted her. "On opening it, she found that the leaves consisted of plates of silver, thick and massive, and every page reflected herself, and that which she wrote down on waking was what she had read in this book. At the point where the exposition broke off, the writing had disappeared from the book and its pages became mirrors in which she beheld only her own image." 47 They both longed

t6 Life of $A . K$., vol. i., pp. 266, 267 ; Story of $A$. K. and E. M., pp. 142-147.

87 This was intended to denote the intuitional nature of the teaching. Anna Kingsfurd was subsequently (on 15th March, 1880) told that she 
for the communication to be completed; and, in due course, it was ; for, two mornings afterwards, Anna Kingsford gave to Edward Maitland a further manuscript of a like character, and in continuation of the furmer one, which, she said, she had received also in sleep-it having been "delivered as a lecture by a man in priestly garb to a numerous class of neophytes," of whom she was one, "as they sat in an amphitheatre of white stone." In her dream she had taken notes of this lecture. Her notes, of course, disappeared with her dream; but she was able, on waking, to reproduce the lecture from memory, when she wrote it down, her memory having been "abnormally enhanced"for "the words presented themselves again to her as she wrote, and stood out luminously to view." 48 Speaking of these Illuminations, Edward Maitland said: "We felt that we had indeed been permitted to tap-so to speak-a reservoir of boundless wisdom and knowledge, and were filled with joy and thankfulness accordingly, for we saw that we had obtained access to a sphere where all memories of the world's past were indelibly preserved and stored up, so that no part of its history, however remote and lost so far

had been enabled, under Swedenborg's magnetism, to visit this Library, and had thus "recovered a memory of no small value." Though associated with Swedenborg, and working on the same lines, Anna Kingsford and Edward Maitland were not indebted to him for their teaching, nor restricted by his limitations (Life of $A . K$., vol. i., pp. 268, 359, 360; and see p. xxiii. post).

${ }^{4}$ Life of $A . K$., vol. i., p. 269; Story of $A . K$. and $E$. $M$. , pp. 147-150. For the full text of these two Illuminations "Concerning the Interpretation of the Mystical Scriptures," see C.W.S., part i., No. v., pp. 16-22. 
as men are concerned, is beyond recovery, and where also are the solutions of all problems." 49

Soon after this, Anna Kingsford had "a terrible illness, lasting several weeks, which threatened to break her down altogether, and, for a long time, quite destroyed her psychic memory"; but, in the following September, her faculty began to recover its power, and, for the next year and a half, she continued to receive similar instructions, most of them being so timed as to come when, having exhausted his own power of interpretation, Edward Maitland stood in need of help, and this generally without Anna Kingsford knowing his need, and always without her being able to supply it had she known it-for, Edward Maitland said, "the knowledges were far beyond us both, as also was the language in which they were expressed." 50

In March 1880, Anna Kingsford found herself again in the Library where she had received the Chapter concerning the interpretation of the Mystical Scriptures, and was told by the same old gentleman who had received her on the former occasion, and whom she again saw, that " he desired to communicate with Mr. Maitland on a matter too delicate to be entrusted to a third person," but that he had a difficulty in doing so, as he (Mr. Maitland) had not been able to find his way to his (the old gentleman's) house. Neither Anna Kingsford nor Edward Maitland, at that time, had any idea as to who the old gentleman was. Soon

th Life of $A . K$., vol. i., p. 268; Story of $A . K$. and E. M., pp. 149, 150.

so E. M., letter in Light, 1888, pp. 127, 128. 
after this, Edward Maitland, while sitting at his work, "received a sudden vivid impression" to the effect that the book which he was writing, and which was then nearly complete, "had better be published anonymously, in order to prevent the consideration of it from being impaired by association with the name of any person." Under date of

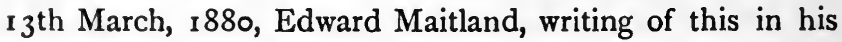
Diary, said: "There was at the time a question about the book which much exercised me, and does so still. It is not that of putting my name to it. I have had no idea of withholding that. It is as to how far I am at liberty to use our chapters on the interpretation of Scripture. I can neither assume the authorship of them, nor can I avow their derivation; and I have been greatly perplexed accordingly. The impression above mentioned was accompanied by another which caused me to exclaim to myself that there was but one person from whom it could justly proceed, this being Emmanuel Swedenborg. For the impression was to the effect that he (Swedenborg) hoped by our means to correct and complete his work." Edward Maitland made no mention to Anna Kingsford of this occurrence, nor had either of them thought of connecting Swedenborg's name with the owner of the Library that Anna Kingsford had visited in sleep. "But" (Edward Maitland's Diary continues) "yesterday evening, having been prompted to sit for some writing, the instrument ${ }^{51}$ wrote the words 'Mr. Maitland.' As this was the first time that I had ever been thus designated by it, or by any of our invisible visitants, and as it

51 A planchette. 
was also the name by which the occupant of the Library had spoken of me, I concluded that it was he who was writing, and, accordingly, inquired whether I was correct in my idea as to what it was that he wanted to say to me. In reply to this, he wrote, 'Not quite,' and presently added, 'It is not considered desirable in our circle that you should produce the book in your name. I will suggest to Mrs. Kingsford what should be done. Good night.-E. S.' These being the initials of Swedenborg, I referred to Carpenter's Life of him, of which I have lately obtained a copy, and found that the specimen there given of his handwriting closely resembled that of our message ; while Mary 52 declared that the portrait of him in the book, which she now saw for the first time, was exactly that of the tenant of the library, showing him as the same placid-looking, smooth-shaven, courtly man, she had described to me. In short, every particular corresponded, even to his formal and measured mode of address, making it impossible to doubt that it was indeed the famous Swedish seer himself who had quitted the earth-life close on a century ago, and that he was now interesting himself in the work of the New Gospel of Interpretation, of which he had been the forerunner" 53

32 "Mary" was the initiation name given to Anna Kingsford.

${ }^{53}$ The doctrine of the communications received by Anna Kingsford concerning the mystical interpretation of Scripture proved to be identical with that of Swedenborg, saving in some particulars which were of such a kind as to show that Swedenborg had advanced to more correct views since his death. The teaching was that of Swedenborg, but without his limitations (E. M., letter in Light, 1885, p. 128). 
Edward Maitland's Diary continues :- "March I4thThis evening Swedenborg came to us again, and, in reference to the change of plans recommended to me, wrote: ${ }^{54}$ 'You may probably have a good deal of recasting to do ; but do not let that discourage you. You will be repaid. In fact, the book should not see the light until the campaign has been opened at Mrs. Kingsford's house by a few parlour addresses from her lips. But do not be too kind to the Christians.' On this we asked what precisely he meant by this caution, when he wrote: 'I use the word in its popular, not in its eclectic sense. You are emphatically Perfectionists. Since I have had my library, I have occupied myself much with pre-Nazarene eclecticism; and I find it much richer and more profound than that of the comparatively uncultivated Nazarite School.' " 55

On the night of 22nd March, 1880, Anna Kingsford dreamt that she and Edward Maitland had a conversation with Swedenborg, who said: "The general plan of your book is good, but you are recommended to avoid identifying the writer with the author of any former work. ${ }^{56}$ Use the first personal pronoun in writing if this facilitates the

${ }^{54}$ Through the planchette, as on the previous occasion. Some few days after the receipt of this message, Anna Kingsford dreamt that Swedenborg told her that he was, in future, forbidden to use the plan chette, since, by its use, deception was courted through the facility with which the lower spirits could use it (Life of $A$. $K$., vol. i., pp. 36o, 361).

${ }^{55}$ Life of $A . K$., vol. i., pp. 357,358 ; Story of $A . K$. and $E . M$., p. 99.

56 Edward Maitland was then well known as the author of several books. 
expression, and as in effect you have used it largely. Let that form stand, but avoid recognition as Edward Maitland. You are recommended to introduce a chapter on the prophetic faculty as the product of Memory, and to cite such passages as occur to you in support of this doctrine. Let this chapter or paragraph introduce the citations you give from the prophetic explanations of the esoteric books of the Bible, and quote them as fragmentary specimens of this recollection occurring to one now a woman, but formerly an Initiate, who is beginning to recover this power by slow degrees." ${ }^{57}$

On the night of the $\mathrm{r} 3^{\text {th }}$ January, $\mathrm{r} 88 \mathrm{r}$, Anna Kingsford, in her sleep, had a conversation with one whom she "recognised as William Lilly, the Astrologer," who had their "Bible of Interpretation," which he refused to communicate to others. On her asking him the reason for his refusal, fixing his eyes upon her intently, he replied, "I will communicate them" (these Scriptures) "when I can find Seven Men who for forty days have tasted no flesh, whose hands have shed no blood, and whose tongues have tasted of none." 58

Shortly after this, Anna Kingsford, speaking under illumination, said: "It seems that we cannot do anything to facilitate the reception of the new Revelation, but my Genius wants me to lecture during the coming season. . . . We may tell all we know, but only to the persons of the

${ }^{87}$ Life of $A . K$., vol. i., p. 361 ; Story of $A$. K. and E. M., p. 98, and see n. (47), p. xvii. ante.

58 Life of $A . K$., vol. i., pp. 435, 441; Slory of A. K. and E. M., pp. $131,132$. 
kind described in my interview with Lilly. If we attempt to speak to others, it will be made impossible for us; we shall be stopped. ${ }^{59}$ This prohibition applies only to the Greater Mysteries. We may speak to others of things historical or interpretative, such as explain or reconcile the religions. He says, I must not lecture under my own name." Subsequently, she said: "My Genius tells me that my addresses are to begin at drawing-room meetings, where, as they will be private, there will be no need to conceal my name. It is otherwise in the case of public assemblies, lectures, and publications. The name must be suppressed for the sake of husband and relatives, and a synonym or an assumed name used. . . My lectures are to begin with the beginning of our work and the earlier truths given to us. The Greater Mysteries are to be reserved until we have a circle of pure livers, in number, if even, of 40,12 , or 10; and, if uneven, of $9,7,5$, or 3 ." 60

Edward Maitland said: "The materials for our coming lectures were in our possession and in abundance, and there was no doubt that more would be forthcoming as we proceeded with the preparation of them; but the task was a vast one, and not only was the time at our disposal short, if we were to take advantage (as we proposed) of the London season-for it was no ordinary quality of

${ }^{39}$ Both Anna Kingsford and Edward Maitland on several occasions had been stopped in a very unpleasant though effectual manner from disclosing certain teachings received by them to people to whom their Illuminators did not wish them to disclose them (Life of $A$. $K$., vol. i., pp. 263, 306 ; Story of $A . K$. and $E . M$., pp. 116, I17).

${ }^{80}$ Life of $A$. $K$., vol. ii., pp. $4,5$. 
workmanship that would serve as the fitting expression for the teaching committed to us-but our own physical condition was still such that, had we only ourselves to trust to, we should have despaired of success. The plan in view comprised the writing and delivery of nine compendious lectures in about as many weeks, and while Mary's health was as variable as ever, comprising rapid alternations from the summits of spiritual insight and power to the lowest depths of disability from pain and weakness, mine-though the 'broken link in the golden chain' had been repaired, as promised, as the Spring advanced and the sun waxed in strength-showed but little abatement of the physical distress, which seemed to have become chronic, and, if curable at all, to require a term of years rather than of weeks or months, and this combined with absolute cessation of mental work. So deep-seated were the effects of the nervous strain and depletion to which I had been subjected during the years passed in Paris.

"The manner of our collaboration in The Perfect Way -for such was the title determined on-was in this wise. Having arranged the order of the exposition and ascertained the number of its main sections, we selected each the subjects which we felt the best able to treat, but not with any intention of confining ourselves exclusively to the subjects thus chosen. It was necessary that our collaboration be particular as well as general, and extend to every sentence and detail, however minute, so that no single word go forth which did not represent the full light of our combined perception. 
Accordingly, whatever was written by either of us was passed to the other to be dealt with freely, and then passed back again to be similarly dealt with anew-a process the result of which was sometimes the complete disappearance of the original draft. Not that there was anything tentative about the doctrine to be expounded. We were both masters of that. The question was of selection, arrangement, and expression, and the restriction of the exposition to the essential and fundamental, the primary and the interior, to the exclusion of the accidental and superficial, the secondary and the exterior. Thus seeking always inwards and upwards to the highest, resolved to be content with nothing short of the highest, it would sometimes happen that what had at first presented itself would vanish in favour of something far superior, of which the former had been the suggestion only, essentially identical, but connoting rather an exterior orbit of the systems of which the latter was the true centre. This was a process which frequently reminded me of the motto of my once favourite pastime, archery-for proficiency in which I had gained the champion's medal in 1878 - the phrase 'Centrum Pete,' and led me to see in that art a training for the lofty work in store for me, while Mary would remark that it was like mounting to a height by climbing alternately on one another's shoulders. And sometimes what we had thus conjointly written would serve as a platform from which she would spring, as it were, into the infinite, so exalted would be the truth suggested, which from such level she was able to discern.

"All that portion of the work which consisted in selecting 
and arranging the teachings received fell to me, Mary desiring rather to reserve herself for the fresh illuminations which might be in store as we proceeded. ${ }^{61}$ And, moreover, I was the more familiar of the two with what had been received, having, as their copyist, committed them largely to memory, while for her they had become somewhat dimmed. Among the sources of my satisfaction, while thus engaged, was the discovery that much of what $I$ had written while in Paris was suitable for use without modification either in substance or in form, many passages fitting in with an exactitude which made them appear as if the context had been contrived expressly to match them." 62

When the time came for the delivery of the lectures, there was no lack of persons who were willing and eager to attend them ; but, owing chiefly to the conditions, to which reference has been made, imposed on them, Anna Kingsford and Edward Maitland were much exercised about the composition of their audience. Finally, an audience of more than average intelligence and culture of the kind required for the appreciation of the message to be delivered was selected. Among those present, there were several whose names are well known as those of persons who have been leaders in the spiritual movement of the age. ${ }^{63}$

The lectures, which were largely written from week to

61 Anna Kingsford received instructions and illuminations while she was preparing, and in connection with the subject matter of her lectures ( $L$ ife of $A$. $K$., vol. ii., pp. 12, 14 ; and see Lects. III., 52 n., and IV., 14).

Life of $A$. K., vol. ii., pp. 10-12.

W Jbid., pp. 14, 16. 
week while in actual course of delivery, were delivered, in the months of May, June, and July, by Anna Kingsford and Edward Maitland in a "little drawing-room" at No. I I Chapel Street, Park Lane, London, ${ }^{64}$ and each lecture was followed by a discussion.

The lectures having been duly delivered, the remainder of the year was spent in preparing them for publication. The revision, first of the text and next of the proofs, was "a task of infinite toil" to them both; but they were "all the time conscious of close supervision." 65 They were anxious to complete the book in time for it to be published during the year I $88 \mathrm{r}$, but, owing partly to the "constant reception of fresh points of light, which required to be added in," 66 they were unable to do it. The other hindering cause was of a very different nature. Edward Maitland said: "We were determined that the printer's part of the work should be as perfect as our own, and it was as if there was a no less resolute endeavour on the other side to baffle us, so persistent were the compositors in making fresh mistakes when in the act of correcting previous ones. Never, probably, was there a book which required so many revises. It seemed to us that a 'printer's devil ' of exceptional malignance had been charged to baffle and spoil our work." 67

64 Life of $A$. K., vol. i., p. 388 ; vol. ii., p. 15 . The name of this street was, in 1886 , changed to, and now is, Aldford Street. The dates on which the lectures were delivered are given in the footnotes to the lectures.

65 All the italicised parts of the book-except where the context shows otherwise-were verbal revelations to Anna Kingsford (Life of $A . K$., vol. ii., p. 33).

${ }^{66}$ Life of $A$. K., vol. ii., pp. 27, 28.

67 lbid., pp. 26, 27. 
The cover of the book was designed by Anna Kingsford. It had "in the centre a figure of the "woman clothed with the sun,' to denote the soul and her full illumination by the spirit; at the corners the symbols of the four evangelists and elemental divinities, which signify the four divisions of existence, both within man and without him; and round the borders the texts, "The Path of the Just is as the shining Light, that shineth more and more unto the Perfect Day!' and 'Arise, shine, for thy Light is come, and the Glory of the Lord is risen upon thee!' Mary was very proud of this design. . . The design on the back cover was the symbol of the double triangle, interlaced, which denotes the interlinking of the worlds unmanifest and manifest; and a monogram composed of the letters $\mathrm{A}, \mathrm{E}$, and $\mathrm{M}$, being the initials of our Christian names and that of Lady Caithness, which was added to our own in token of her part in the enterprise." 68

On the $4^{\text {th November, }}$ 188 I, Anna Kingsford, writing to Lady Caithness, said: "I doubt not that Mr. M. keeps you 'posted up' in the progress of the Book, which we are doing our utmost to get out as a Christmas present to the

${ }^{69}$ Life of $A . K$., vol. ii., pp. 33, 34. Art. in Light, 1895, p. 32. Lady Caithness had undertaken to bear the expense of the publication of The Perfect Way, which was " a costly book to publish," under the conviction that she had been "divinely charged with the duty" (Life of $A . K$., vol. ii., p. 27). It will be noticed that the letters A, E, and $M$, spell the French word AME (Soul). In I889, Lady Caithness published in her magazine L'Aurore a French translation of The Perfect Way, and this was, in $189 \mathrm{I}$, issued in book form, in response to urgent requests from Catholic Priests in France, who recognised in it the interpretation they had long sought of their own religious mysteries. 
world. You can have no idea what a labour it has been, and, I may say, still is : for not only has it been exceedingly difficult to compress into moderate dimensions, and to express clearly in popular language, the enormous mass of truth we have to put forth, but we have also found it necessary to elucidate the text by means of woodcuts, the designing, copying, and perfecting of which, having been exclusively assigned to me, have occupied a considerable amount of time. The Triangle, which occupies so large a part in your own symbolic system of thought, is now newly exemplified in the threefold united effort by means of which our book is to be introduced to the world. And it seems to be somewhat significant that the trio thus chosen represents, respectively, three distinct powers, with none of which we could have dispensed.... I regard the prophecy concerning this year as already fulfilled in the production of our book, which will, for the first time in the world's history, 'make straight the way of the Lord,'-the Perfect Way." 69

The work accomplished in the production of The Perfect Way, was, Edward Maitland said, "accomplished only at that maximum cost, physical, mental, and other, which seemed to be the appointed condition of all our work; and, indeed, it sometimes seemed as if the two things were in inverse ratio to each other, and that the greater the cost and suffering, the greater the results to the work, and the more the sowing had been in tears, the more the reaping was in joy:" 70 but, he said, "Since we had neither sought nor obtained the revelation in it for our own exclusive benefit${ }^{69}$ Life of $A$. $K$., vol. ii., pp. 4I, 42. ${ }^{70}$ Ibid., p. 73. 
but for the world's salvation from the abyss of Materialism and Negation in which it was being rapidly engulfed-we were prepared and ready to undertake it at any sacrifice to ourselves." 71

The Perfect Way was actually published in February, 1882 ; and, in accordance with the directions given to the Writers, it was published anonymously; and it was "bound in the nearest colour to purple that was to be had, namely, a peacock blue," in order-while including the Seven Spirits of God-to combine Anna Kingsford's and Edward Maitland's own colours, the red and the blue. ${ }^{72}$

The book received a reception that its Writers, while not taken by surprise, could hardly have looked for, as the following extracts from two letters, written by Anna Kingsford to Lady Caithness, soon after its publication, show. "Strange indeed it would be," she said, "if our book should find universal acceptation in a world which rejected Christ! But those who do recognise our teachings do so not warmly only, but enthusiastically ;"73 and, in a further letter written to the same lady, after referring to a

${ }^{71}$ E. M., letter in Light, 1895 , p. 38. In the same letter, Edward Maitland said that the cost of keeping The Perfect Way and its com. panion books before the world had so greatly exceeded the return accruing from sales, as to have constituted a drain on his resources such as preventerl him publishing much else that would have been of high value to the world.

${ }^{72}$ Life of $A . K$., vol. ii., p. 33. The Seven Spirits of God are repre. sented in the seven colours of the prism, the first and last of which are red and violet respectively; and the co-operation of all these Divine Potencies was indispensable to their work (Story of $A . K$. and $E . M$., pp. 109, 110).

${ }^{73}$ Life of $A . K$., vol. ii., p. 56 . See also $A$ pp. No. III. 
certain review which had then recently appeared, and which amounted to a misrepresentation "so gross and palpable" that she found it hard to believe that it had been committed innocently, she said: "After all this reviewing and faultfinding on the part of critics having but a third of the knowledge which has been given to us, there is not a line in The Perfect Way, which I would alter were the book to be reprinted. . . . I have no fear that the Immortals will deceive me, nor am $I$ in the least disconcerted by adverse criticism. That others do not see, and cannot understand, proves only how greatly our work is needed in the world, and how far it surpasses all minor labours and teaching. Let no one, dear friend, shake your constant mind from the great doctrines which we have of the Holy Powers themselves. For all other teaching, save that which is based on Justice, shall come to nothing. 'The just Lord loveth justice ; His countenance beholdeth the thing that is just.' Try all the doctrine of The Perfect Way by this supreme test, and see if it does not in all things satisfy and fulfil it as does no other under the sun. All are broken lights,lights indeed, but fragmentary merely; one teaching including some stray beams, and others more. But to us the Gods have given without measure, a perfect and glorious orb of complete glory, and if we be but faithful, there is nothing we may not know." 74

Edward Maitland, writing at a subsequent period, summed up the position as follows. He said: "Had we been sanguine about the reception of this book by the ${ }^{74}$ Life of $A$. K., vol. ii., p. 75 . 
general press, secular or religious, the event would have been a grievous disappointment, but we were spared this by our knowledge of the world's spiritual state. With a press one half of which was inveterately Sadducee, and the other half inveterately Sacerdotal and wedded to traditions which make the Word of God as revealed by the pure intuition of none effect, and with the spiritual consciousness flesheaten out of existence, the audience to which we appealed had yet to be created. In most of the few cases where our book was valued at all, we were taunted with superstition for believing in a spiritual world! As if the real superstition was not the worship of matter, and the crediting of it with being the substance of the universe." 75

On the other hand, The Perfect Way was quickly recognised by many of the profoundest students and most advanced souls of the time, irrespective of creed, nationality, or race, as being a full and faithful exposition of the nature of existence such as had never before been given to the world, and "as representing the recovery, under celestial guidance, of the original revelation which constituted the Gnosis, or Knowledge, which belonged to the sacred mysteries of antiquity, and of which their various Scriptures and religions were expressions, and with the taking away and withholding of the key to which Jesus so bitterly reproached, in the ecclesiasticism of His time, that of all time." i6 To name a few only of those who received the ${ }^{75}$ Life of $A . K$., vol. ii., p. 49 ; and see Story of $A$. K. and E. M., pp. $187,188$.

${ }_{76}$ E. M., letters in Light, 1893, p. 103, and 1894, p. 477 ; and Obituary Notice of A. K. in Light, 1888, p. 116. 
Revelation with gladness. Dr. Ernst Gryzanowsky-who has been described as " a man of the rarest order of intelligence and width of culture"-after reading The Perfect Way, wrote to Edward Maitland: "I fully acknowledge the fundamental truths of your philosophy, which is, without a doubt, the noblest and purest form of spiritualism I have yet met with. It is, at the same time, the most comprehensive form of spiritualism, containing or implying all that is worth having in the so-called mystic lore of ancient and modern times." i7 Lady Caithness, whose name has already been mentioned, after reading the book, wrote of it: "I have got another Bible," and she declared it to be "the most complete Revelation, certainly, that has yet been given to man on this Planet," 78 and she described it as "that most admirable book which embodies the latest, highest, and most important revelations given to humanity, constituting a new Gospel which thousands would thankfully receive could the work in question be brought to their notice; for thousands are at this time literally starving for want of spiritual food adequate to the needs of their present spiritual growth;" and she said, "I have no hesitation whatever in pronouncing it to be the new Gospel of Interpretation of the Mysteries of God kept secret from the beginning." 79 "It is a noble book, breathing inspiration in every word." 80 The late Reverend G. J. R. Ousely, M.A., who, at one time, was a priest in the Catholic Apostolic 
Church, but who afterwards joined the Roman Catholic Church, and who was well known as a Christian Mystic and as having considerable knowledge of occult things, said of The Perfect Way that it was "the brightest and best of all revelations that had ever been given to the world," and that "the Church of the future would be the Church of The Perfect Way;" 81 and, when writing of the book shortly after its publication, he described it as "that most wonderful of all books which have appeared since the beginning of the 'Christian Era,'-a book that no student can be without if he will know the truth on these matters. It furnishes us with a master key to the phenomena which so perplex the minds of inquirers, and it gives a system of which the like has not been for eighteen centuries. Swedenborg was great indeed, but here we find a greater, without the prolixity and voluminousness of the Swedish seer and with a clearness which is wanting in his writings." 82

In May, 1886, Anna Kingsford and Edward Maitland were "very busy getting ready the revised edition of The Perfect Way," which was to contain "a new lecture and many alterations and improvements"; 83 and, in the following October, it was in the press; but, owing to fresh matter which had to be included in it having been imparted to Anna Kingsford at the last moment, the publication was delayed until the following January. ${ }^{84}$ As it was impossible ${ }^{81}$ See article in Light, 1907, p. 4.

82 Letter in Light, 1882, p. 475.

${ }^{83}$ A. K., letter to Lady Caithness; Life of $A . K$., vol. ii., p. 234.

os Light, 1886, p. 310. 
for Anna Kingsford and Edward Maitland to keep their names as the writers of the book secret, the Second (revised) Edition was not, like the First Edition, published anonymously. The new lecture referred to was Lecture V., on "The Nature and Constitution of the Ego," which was written by Edward Maitland-almost entirely from revelations received by Anna Kingsford-in substitution for the corresponding lecture on "The Constitution of Existence : Its Nature and Unity," in the First Edition. ${ }^{85}$

Anna Kingsford did not live to see the publication of the Third Edition of The Perfect Way; but, a few weeks before her death, which took place in her forty-second year, on the 22 nd. February, 1888, she read the book for the last time-for she "gloried in it" to the end, and considered it "the supreme privilege of her life to have been a sharer in its production;" 86 and, on her death-bed, "she received from time to time Illuminations which she described rapturously as being most glorious," "confirming and amplifying" all that she and Edward Maitland had been taught, and "disclosing vista after vista of the divinest truth and beauty beyond." To her great regret, she was too weak then to dictate the particulars or to write them down; but she was able, partly by the light of these Illuminations, to give to Edward Maitland some suggestions for adoption in the

85 This lecture is reprinted in and forms Appendix No. I. of the present Edition.

${ }^{86}$ Shortly before her death, she drew up what might be termed a confession of faith, in which she said: "In the faith and doctrine set forth in that book" (The Perfect Way) "I desire to die" (Life of A. K., vol. ii., p. 305). 
next Edition when the time should come for issuing a new Edition. ${ }^{87}$ The most important of these was with reference to paragraphs 27-4I inclusive (which had been written jointly by her and Edward Maitland) of Lecture VIII., which she considered were "capable of improvement chiefly by means of amplification and extension;" and, being desirous only of leaving the book in the highest state of perfection, she advised that "in order to obtain the space requisite for the new matter-the book being stereotyped - several pages-about eighteen-be omitted. Not that she regarded their contents in any way as erroneous, but she considered the proposed new matter as of superior value." 88 Edward Maitland undertook, and regarded it as "a sacred duty," to carry out Anna Kingsford's last wishes ; 89 and, after her death, he revised The Perfect Way accordingly and finally settled the text of the book ; and the Third Edition, so revised and settled, was published in 1890 . In a short advertisement to that Edition, Edward Maitland expressly stated that the alterations made therein involved "no change or withdrawal of doctrine, but only extension of scope, amplification of statement, or modification of expression," and that "the principal changes," which consisted in "the substitution of new matter for the greater

87 Life of $A . K$., vol. ii., pp. $337,338,365,367$; E. M., letter in Light, 1891 , p. 416.

Life of $A$. K., vol. ii., pp. 33, 367, 371, 382. These paragraphs, 27-41 of Lecture VIII. of the Second Edition, are reprinted in and form Appendix No. II. of the present Edition. The "plates" also are reprinted in the present Edition.

Life of $A$. $K$., vol. ii., p. 375. 
part of paragraphs 27-4I in Lecture VIII., and the omission of the plates," were "made in accordance with Mrs Kingsford's last wishes and suggestions."

I have regarded the text of The Perfect Way, as finally settled by Edward Maitland, as sacred; and the nine lectures which comprise the present Edition are a reprint of the nine lectures which comprised the Third Edition. Nothing has been added to, and nothing has been abstracted from these lectures, or any of them. In the Appendices to the present Edition, I have, as already mentioned, included Lecture No. V. of the First Edition (which was, in the following Editions, superseded by the present Lecture No. V.), and paragraphs 27-4I of Lecture No. VIII. of the Second Edition (which were, in the Third Edition, superseded by the corresponding paragraphs of the present Lecture No. VIII.), and I have included some letters written by Anna Kingsford and Edward Maitland to Light on "The Perfect Way and its Critics," which are of great interest and considerable value. The addition of this new matter has made it impossible to retain in the present Edition the Appendices-which consisted of some of Anna Kingsford's Illuminations or portions thereof - to the former Editions ; but, as these Illuminations are all included in Clothed With the Sun, which was published in $1889,{ }^{90}$ their omission is of no consequence. I have also included in the present Edition the ten illustrations ("plates") that were in the First Edition, some only of which were in the

${ }^{90}$ Clothed With the Sun: being the Book of the Illuminations of Anna (Bonus) Kingsford, Second Edition, 1906. 
Second Edition. There were not any illustrations in the Third Edition. The present Edition, with the above mentioned additions, is thus the first complete edition of The Perfect Way, comprising, as it does, all the lectures that have been published in the former Editions.

Anna Kingsford's share in writing The Perfect Way, alone, and apart from her other writings, has gained for her the reputation of being " a seer and prophet of unsurpassed lucidity and inspiration," 91 for the doctrine of The Perfect Way was not received from any "extraneous or obsessing spirit or control;" nor, indeed, from any outside source whatever, but from "the divine and interior spirit;" and it was discovered only subsequently that the revelation thus made was not new, but, as has been said, was contained and formulated in the Hebrew Kabbala, in Hinda philosophy, and not less clearly in the mysteries of Egypt and Greece : ${ }^{92}$ and these illuminations and inspirations were received by Anna Kingsford chiefly during natural sleep. ${ }^{93}$ The Perfect Way constitutes nothing less than a re-delivery from or through the Soul-the source whence it originally came-of that Divine Gnosis, to which reference has been made, which underlay and controlled all the world's great Religions and Bibles, and by the aid of which alone these can be interpreted. And this was given to Anna Kingsford " not in suggestions and ideas only, but in language clear, precise, and exquisite, wholly beyond her own power of composi-

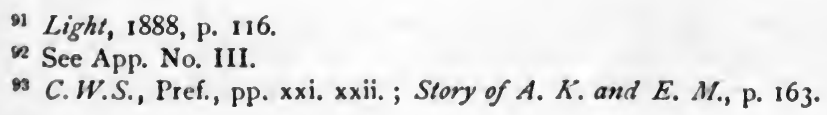


tion, and accompanied by dramatic experiences of the most striking kind." 94 For just as the original and ancient Revelation was derived from or through the divine part of man's nature, so the recovery of it was thence derived, that part of his nature being always accessible to those who lead the requisite life, and direct the force of their minds inwards and upwards in search of it. The method of Divine Revelation is always the same, namely, the intuition operating under spiritual illumination. ${ }^{95}$ And not only was this revelation not due to "guides" in the ordinary sense, it was not-as some have supposed-made solely to or through Anna Kingsford. "It was made," said Edward Maitland, " to us both, and this, not by extraneous spirits, but by our own souls directly and through our own consciousnesses." 96 The Perfect Way, therefore, represents " the attainment of communion with the innermost and highest in man himself, his own Central and Divine Spirit, the God within, than whom there is no higher source accessible of light and life, seeing that the God within is one with the God without, and that only through the God within can the God without be approached." 97

Respecting the nature and range of the marvellous faculty by the possession of which Anna Kingsford was so far removed from the category of ordinary "mediums" and inquirers into esoteric science, the following passage ${ }^{94}$ E. M., Obituary Notice of A. K., Light, 1888, p. $116 ;$ Life of $A$. $K$., vol. ii., pp. 347,348 .

${ }^{95}$ See also C.W.S., Pref, pp. xxiii., xxiv.

${ }^{96}$ E. M., letter to Madame de M., Ioth July, r89r.

97 E. M.'s MS. on "The Perfect Way"; and see App. No. III. 
(written by Edward Maitland) from a letter, dated 18 th March, I884, addressed by her and Edward Maitland to the Fellows of the London Lodge of the Theosophical Society, is of considerable interest and importance. Edward Maitland says: "This, she wishes it to be clearly understood, is not an occult faculty in the common acceptation of the term. It involves no abnormal powers voluntarily directed, or acquaintance with any method requiring to be imparted by initiation of the secondary intellectual principles. Nor, again, does the condition in which it is exercised resemble the trance of ordinary clairvoyance. She is, therefore, neither a 'trained occultist' nor a natural clairvoyante. The faculty she possesses is one with which she was born, and it has been developed by a fourteen years' abstinence from flesh-food, and by a series of experiences and a manner of life not altogether at first the result of choice. Students of the Platonic Philosophy will recognise the condition in question as one illumination affecting the soul rather than the mind. It is believed by her to be the result of psychic reminiscence, through which the gnosis acquired by initiation in a previous birth is revived and unfolded to her perception. She has strong reason for the conviction that the school, in virtue of her initiation into which these illuminations occur, was the Greco-Egyptian. The state during which they present themselves is one of intense and breathless concentration. The whole outer personality appears to be superseded and transcended, and knowledges are vividly borne in on the interior understanding as a vision, often of symbolic character. It has been shown by 
means of these very illuminations that this condition, described as the result of psychic reminiscence, is, in her, exceptionally developed in consequence of the period now reached by her interior selfhood in its planetary evolution. Hers is represented to be an advanced Ego, which, having returned to definite existence more rapidly and persistently than is the normal case, has thus got ahead of the case generally, and thereby developed a faculty which will in time be attainable by all souls who have been really initiated in a former birth. But this reminiscence is possible only in respect of the religious gnosis, dealing with principles and metaphysical truth, not in respect of that which, being intellectual and dealing with the condition and exercise of occult power, affects the physiological memory, and cannot be transferred from one birth to another in the manner described." 98

Edward Maitland died on the and October, 1897 , at the close of his seventy-third year, a little more than nine years after the death of his colleague.

Such is, shortly, the history of The Perfect Way which has restored to the world the long lost system, which is none other than the Esoteric Christianity of the Catholic Church, and which alone has ever been able to grapple with and overcome the "dragon" of Materialism, and has thus afforded a full demonstration of the truth of that system, inasmuch as the knowledges contained in it were recovered, as they alone could be recovered, by means of the Intuition, and in the pages of which, Edward Maitland said, "the very life-

${ }^{98}$ See also C.W.S., Pref., p. xxv., note (3). 
blood of our souls " was " shed for the world's redemption." 99 Without doubt, The Perfect Way, as Edward Maitland has said, "is destined largely to control the faith, worship, and practice of the future." 100 In a letter dated 5 th April, I 882, to Lady Caithness, Anna Kingsford said :-

"Of one thing I am sure; which is, that the Doctrine of which our book is the first Apostle will sooner or later become the headstone of the corner; for it is the only doctrine capable of explaining the otherwise insoluble enigmas of the universe, and embodying a philosophy in which are united all the elements of every divine revelation vouchsafed to mankind. By it Christian and Buddhist, Parsee and Hebrew, Greek and Egyptian, are brought into harmony, and shown to be only so many different dialects of one Catholic language. The Perfect Way is thus an eirenicon, and "the Peace-maker is the Child of God." "101

As the faculty employed by Anna Kingsford and Edward Maitland in the production of The Perfect Way was the Intuition operating under Spiritual Illumination, the doctrine of The Perfect Way cannot be regarded as mere speculation, for "the intuition is not a creative, but a perceptive and recollective faculty; ${ }^{102}$ and, therefore, its results are not surmises or opinions, but knowvledges, inasmuch as they are formulated in actual experience acquired" (by the Soul) "either in the present or in past lives." 103 Edward Maitland

20 Life of $A$. K., vol. ii., p. 356.

101 Ibid., p. 56. See also App. No. III. ${ }^{102}$ See Lect. I., 12.

${ }^{103}$ Letter dated 1oth July, 1882, from "The Writers of The Perfect Way" to The Theosophist. See also letter of E. M. in the Agnostic Journal, 25th August, 1894 
said, the doctrine "is no mere matter of opinion, but truth as clear, as certain, as impossible to be otherwise, as the demonstration of any mathematical proposition: so that any divergency from it must represent false teaching:" 104 for the truths disclosed to Anna Kingsford are "every whit as necessary and self-evident to the spiritual apprehension as those of Geometry to the intellectual." 105 But while Anna Kingsford and Edward Maitland found that the system given to them was "an infallible touchstone" whereby to test all others, ${ }^{106}$ they did not accept it on the strength of their having been told it, for, as Edward Maitland said, "one does not know a thing for being told it ;" nor did they accept it on the strength of the manner of its communication. They accepted it on the strength of their recognising and discerning it as necessary truth, founded in the nature of existence, and incapable of being otherwise, just as two and two are incapable of being anything but four. ${ }^{107}$ And for this reason they did not rest their teaching on authority-whether of Book, Person, Order, Institution, Tradition, or Convention - but relied solely upon the strength of experience, and (as stated in the Preface to the First Edition) appealed to the understanding as the basis of belief. ${ }^{108}$ The Perfect Way is really a record of experiences,

104 E. M., letter to Lady C., 9 th July, I891.

105 E. M., letter, dated 21st March, 1888, to The Tablet.

${ }^{106}$ Life of $A$. $K$., vol. ii., p. 200.

107 E. M., letter to Mad. de M., Ioth July, 1891 ; and see C.W.S., Pref., p. xxii.

108 E. M., letter in Light, I892, p. 620; and see Lect. I., 23-25, 51, 52 ; and $C . W . S .$, Pref., pp. xxii., xxiii. 
although, as a rule, the results only are given: hence the positiveness of the writers.

In conclusion, I ask the readers of this book to consider the following passage, taken from the Christian Scriptures, ${ }^{109}$ in conjunction with the interpretation put upon it by Anna Kingsford :-

"And it came to pass that when the multitudes pressed upon Him to hear the Word of God, He stood by the Lake of Genesareth, and $\mathrm{He}$ saw two ships standing by the Lake; but the fishermen were gone out of them, and were washing their nets. And going into one of the ships that was Simon's, He desired him to draw back a little from the land. And sitting, He taught the multitudes out of the ship. Now when $\mathrm{He}$ had ceased to speak, He said to Simon: Launch out into the deep, and let down your nets for a draught. And Simon answering, said to Him: Master, we have laboured all the night, and have taken nothing; but at Thy word I will let down the net. And when they had done this, they enclosed a very great multitude of fishes, and their net broke. And they beckoned to their partners who were in the other ship, that they should come and help them. And they came, and filled both the ships, so that they were almost sinking. Which, when Simon Peter saw, he fell down at Jesus's knees, saying: Depart from me, for I am a sinful man, O Lord. For he was wholly astonished, and all who were with him, at the draught of the fishes which they had taken. And so were also James and John the sons of Zebedee, who were Simon's ${ }^{109}$ Luke v. $1-10$, 
partners. And Jesus saith to Simon: Fear not: from henceforth thou shalt catch men."

Anna Kingsford, writing as "a Toiler in the Ship of Peter," says :-

"In this Parable the Christ standing up by the water-side is the Logos, the Word of God, and the Lake by which he stands is the Psychic Element, the Soul of the Macrocosm and Microcosm (Genesareth, the Garden of God). Beside these spiritual waters there are two ships, but they are empty; their owners have gone out of them and are washing their nets. These empty ships are the two ancient parent Churches of East and West, the Oriental and the Pagan. At the time of the re-birth of the Mysteries under the Christian dispensation, both these Churches were barren and vacated; the life and vital power which once thundered from their Sinais and Olympuses were dead and gone out of them; the glory of their ancient oracles and hierarchies was no more; the nets with which they once had caught the Gnosis and spiritual graces needed cleansing and renovation; the vivifying Spirits or Angels which had animated these two Churches had forsaken their shrines.

"And the Christ, the Word, entered into one of them, which was Peter's, and desired him to thrust out a little from the land. The ship into which the Christian Logos thus entered at its outset was undoubtedly the Pagan Church which had its headquarters at Rome. It can be proved from monumental evidence and from the writings of the Fathers (see, inter alia, Monumental Christianity by Presbyter Lundy), that the new faith, whose epiphany must 
have been at Alexandria, adopted from its earliest age the symbols, the rites, and the ceremonials of the expiring Pagan system, incorporating them into its own Mysteries, endowing them with new vitality, and thus perpetuating and preserving them almost intact to our own times.

"Peter is the universally accepted representative of the Genius of Rome. Peter's ship is the Roman Church of this day, even as the ship of Janus was in pre-Christian times the appropriate symbol of Pagan Rome. Peter is the opener and shutter of the Gates of the Church, even as Janus was of the portals of heaven. ${ }^{110}$ It is, therefore, into this Pagan Church of Rome that the Logos enters, and prays its Genius to thrust out a little from the land. Now, in sacred allegory, the 'land' or earth is always a figure for the bodily element, as opposed to water, or the soul. It represents Matter, and the material plane and affinities.

"We see, then, that the Word, or "Christ," demanded in this first age of the Christian dispensation the partial spiritualisation of the existing Church,-demanded the basis of doctrine and dogma to be shifted from the mere dry earthy bottom of materialism and hero-worship on which it had become stranded, to the more appropriate element of ethical religion, the province of the soul,- not yet, however, far removed from the shallows of literalism and dogma. This done, the Word abides in the renovated Church and, for a time, teaches the people from its midst.

"Then comes the age which is now upon us, the age in which the Logos ceases to speak in the Christian Church; 
and the injunction is given to the Angel of the Church: Launch out into the deep and let down your net for a draught. Quit the very shores and coasts of materialism; give up the accessories of human tradition which, in this era of science, are both apt to offend and so to narrow your horizon as to prevent you from reaping your due harvest of truth; abandon all appeals to mere historical exegesis, and launch out into the deeps of a purely spiritual and metaphysical element. Recognise this, and this alone henceforward, as the true and proper sphere of the Church.

"And the Apostle of the Church answers, Master, all through the dark ages, the mediæval times in which superstition and sacerdotalism reigned supreme and unquestioned - the night of Christendom, - we toiled in vain; the Church acquired no real light, she gained no solid truth or living knowledges. But now, at last, at Thy word, she shall launch out into the deep of thought, and let down her net for a draught.

"And a mighty success is prophesied to follow this change in the method and system of religious doctrine. The net of the Church encloses a vast multitude of mystic truths and knowledges,-more even than a single Church is able to deal with. Their number and importance are such that the Apostles or Hierarchs of the Christian Church find themselves well-nigh overwhelmed by the wealth of the treasury they have laid open. They call in the aid of the ancient Oriental Church, with its Angels, to bear an equal hand in the labours of spiritualisation, the diffusion of truth, the propaganda of the divine Gnosis, and the triumph 
of esoteric Religion. Henceforth the toilers in the two Churches of East and West are partners; the Vedas and the Tripitakas find their interpretation in the same language and by the same method as the Christian evangel ; Chrishna, Buddha, and Christ are united, and a true Brotherhood-a true Eirenicon-is preached to men.

"From that day forth, the Church Catholic and Christian need have no fear, for she shall indeed 'catch men.'"111

SAMUEL HOPGOOD HART.

Croydon, October, 1908.

${ }^{111}$ A. K., letter to the President of the T.S., 31st October, 1883. 


\section{PREFACE TO THE SECOND (REVISED) EDITION.}

As the writers-rather than the authors-of this book, we propose - on behalf of a more ready apprehension of it, and the satisfaction of much questioning concerning it-to take occasion on the issue of this Edition to give a succinct account of its nature and import.

That which The Perfect Way represents is neither an invention nor a compilation, but first, a discovery, and next, a recovery. It represents a discovery because it is the result of an attempt-proved successful by the issueto ascertain at first hand the nature and method of existence. And it represents a recovery because the system propounded in it has proved to be that which constituted the basic and secret doctrine of all the great religions of antiquity, including Christianity, - the doctrine commonly called the Gnosis, and variously entitled Hermetic and Kabbalistic.

In yet another sense does The Perfect Way represent a recovery, and also-for ourselves - a discovery, seeing that it was independent of any prior knowledge on our part. This is as regards Faculty. For the knowledges concerned. 
although verified by subsequent research in the ordinary manner, were obtained solely by means of the faculty which consists in perception and recollection of the kind called intuitional and psychic, and therefore by the method which in all ages has been recognised as the means of access to knowledges transcendental and divine. Being fully described in the book (e.g., Lect. I., pars. 4-18; C.W.S., part i., No. ii. (r), pp. $5^{-8}$, etc.), this faculty needs no further definition here. It is necessary, however, to state this in relation to it: That the value of the recovery of the knowledges concerned, great as it is for the intrinsic interest and importance of the subject, is indefinitely enhanced by the manner of its accomplishment. For, much as it is to know the conclusions of ancient wisdom concerning the most momentous of topics, and to recognise their logical excellence, it is far more to know their truth, seeing that they involve the nature and destiny of man in all time. It is this supreme question which finds satisfactory solution in the present case. Had the recovery been made in the ordinary manner, namely, through the examination of neglected writings, or the discovery of lost ones,-methods which, however successful, would have been altogether inadequate for the results actually attained,-no step would have been gained towards the verification of the doctrines involved. Whereas as it is, for ourselves, and for all those who with us are cognisant of the genesis of this book, and who are at the same time sufficiently matured in respect of the spiritual consciousness to be able to accept the facts, - that is, for all who know enough to be able to believe, - the book constitutes of itself 
an absolute confirmation of its own teaching, and, therein, of the recovered Gnosis. For, being due to intuitional recollection and perception,-faculties exercised in complete independence of the physical organism,-it demonstrates the essentially spiritual nature of existence; the reality of the soul as the true ego; the multiple rebirths of this ego into material conditions; its persistence through all changes of form and state; and its ability, while yet in the body, to recover and communicate of the knowledges which, in the long ages of its past as an individualised entity, it has acquired concerning God, the universe, and itself. In respect of all these, the experiences of which this book is the result-although themselves rarely referred to in ithave been such, both in kind and quantity, that to regard them and the world to which they relate as delusory, would be to leave ourselves without ground for belief in the genuineness of any experiences, or of any world whatsoever. It is not, however, upon testimony merely personal or extrinsic that the appeal on behalf of this book is rested, but upon that which is intrinsic, and capable of appreciation by all who have intelligent cognition of the subjects concerned.

Especially is this book designed to meet the peculiar circumstances of the times, - so aptly described by $\mathrm{Mr}$. Matthew Arnold when he says that "at the present moment there are two things about the Christian religion which must be obvious to every percipient person; one, that men cannot do without it ; the other, that they cannot do with 
it as it is." In an age distinguished, as is the present, by all-embracing research, exhaustive analysis, and unsparing criticism, no religious system can endure unless it appeals to the intellectual as well as to the devotional side of man's nature. At present the faith of Christendom is languishing on account of a radical defect in the method of its presentation, through which it is brought into perpetual conflict with science; and the harassing and undignified task is imposed on its supporters of an incessant endeavour to keep pace with the advances of scientific discovery or the fluctuations of scientific speculation. The method whereby it is herein endeavoured to obviate the suspense and insecurity thus engendered, consists in the establishment of these three positions:-

(I) That the dogmas and symbols of Christianity are substantially identical with those of other and earlier religious systems. essentizly with the religion

(2) That the true plane of religious belief lies, not where hitherto the Church has placed it,-in the sepulchre of historical tradition, but in man's own mind and heart; it is not, that is to say, the objective and physical, but the subjective and spiritual; and its appeal is not to the senses but to the soul. And,

(3) That thus regarded and duly interpreted, Christian doctrine represents with scientific exactitude the facts of man's spiritual history.

It is true that many men renowned for piety and learning - pillars, accounted, of the faith-have denounced as in the highest degree impious the practice of what they call 
"wresting Scripture from its obvious meaning." But their denunciation of impiety includes not only the chief of those "lesser lights," the Christian Fathers and Jewish Commentators, but also those "two great lights," Jesus and Paul, seeing that each of these affirmed the mystic sense of Scripture, and the duty of subordinating the Letter to the Spirit and seeking within the veil for the meaning. The fact is, that in their use of the term "obvious," the literalists beg the questions involved. Those questions are, - To what faculty is the sense of Scripture obvious,- - to the outer or the inner perception? and,-To which of these two orders of perception does the apprehension of spiritual things rightly belong? Nothing, assuredly, can be more obvious than the "impiety" of setting aside the account which Holy Writ gives of itself, and ascribing to it falsehood, folly, or immorality, on the strength of outward appearance, such as is the letter. ${ }^{1}$ To those whom this volume represents, it is absolutely obvious that the literal sense is not the sense intended; and that they who insist upon that sense incur the reproach cast by Paul when, referring to the veil which Moses put over his face, he says: "For their minds were blinded; for until this very day at the reading of the old covenant the same veil remaineth unlifted. Even unto this day the veil is upon their hearts."

We will endeavour briefly to exhibit the principles of this conclusion. The first lesson to be learnt in the school of philosophy is the truth that the mind can apprehend and

See further as to this The Bible's Own Account of Itself, by Edward Maitland, Second Edition (1905), Preface. 
assimilate that only which presents itself mentally. In other words, the objective must be translated into the subjective before it can become pabulum for the spiritual part of man. Truth is never phenomenal, but always metaphysical. The senses apprehend and are concerned with phenomena. But the senses represent the physical part only of man, and not that selfhood which the philosopher intends when he speaks of Man. This, the true ego, cannot come into relation with, or take account of, events and persons which present themselves phenomenally and objectively only. Thus, they are but vehicles and symbols by which truths, principles, and processes are conveyed to the subjective apprehension,- the hieroglyphs, so to speak, in which these are portrayed. Belonging to time and to matter, persons and events are-in their phenomenal aspect -related only to the exterior and perishable man; while principles and truths, being noumenal and eternal, are cognisable only by that in man which, being also noumenal and eternal, is of like nature with them, namely his subjective and spiritual part. For the apprehender and that which is apprehended must belong to the same category. And as the former is, necessarily, the purely rational principle in man, the latter also must be purely rational. For this reason, therefore, in order to maintain its proper spirituality, religion must always-as Schelling points outpresent itself esoterically, in universals and in mysteries. Otherwise, being dependent for its existence upon the continuance of an environment merely physical and sensible, it becomes as evanescent as is this. From which it follows 
that so long as we regard religious truth as essentially constituted of and dependent upon causes and effects appertaining to the physical plane, we have not yet grasped its real nature, and are spiritually unconscious and unilluminate. That which is true in religion is for spirit alone.

The necessary subjectivity of truth was affirmed also by Kant, who regarded the historical element in Scripture as indifferent, and declared that the transition of the Creed into a purely spiritual faith, would be the coming of the kingdom of God. Similarly the mystic Weigelius (A.D. 1650) says that in order to be efficacious for salvation, that which is divinely written concerning the Christ on the objective plane, must be transferred to the subjective plane and substantialised in the individual, being interiorly enacted by him. And the pious and learned translator of the Hermetic books, Doctor Everard, writes:- "I say there is not one word (of Scripture) true according to the letter. Yet I say that every word, every syllable, every letter, is true. But they are true as $\mathrm{He}$ intended them that spake them ; they are true as God meant them, not as men will have them" (Gospel Treasury Opened, A.D. 1659).

The reason is that matter and its attributes constitute but the middle term in a series the Alpha and Omega of which are spirit. The world of ultimate effects, like that of ultimate causes, is spiritual; and no finality can belong to the plane of their middle term, this being a plane only of transition. The absolute is, first, pure abstract thought. It is, next, a heterisation of that thought by disruption into the atomism of time and space, or projection into nature, a pro. 
cess whereby, from being non-molecular, it becomes molecular. Thirdly, it returns from this condition of self-externalisation and self-alienation back into itself, resolving the heterisation of nature, and becoming again subjective and -as only thus it can become-self-cognisant. Such-as formulated by Hegel-is, under manifestation, the process of universals ; and such is, necessarily, the process also of particulars, which are the product of universals. Wherefore man, as the microcosm, must imitate, and identify himself with, the macrocosm, and subjectivise, or spiritualise, his experience before he can relate it to that ultimate principle of himself which constitutes the ego, or selfhood.

Such a view of religion as this, however, is obviously incomprehensible save by the educated and developed: its terms and its ideas alike being beyond the capacity of the generality. This book, therefore, and the work which it inaugurates, are addressed to the former class;-to persons of culture and thought, who, recognising the defects of the popular belief, have abandoned, as hopeless, the attempt to systematise it and to relate it to their mental needs. There never can be one presentation of religion suited equally to all classes and castes of men; and the attempt of the Church to compass this impossibility has, of necessity, resulted in the alienation of those who are unable to accept the crude, coarse fare dealt out to the multitude. Enacting the part of a Procrustes in respect of things spiritual, she has tried to fit to one measure minds of all kinds and dimensions, in total disregard of the apostolic dictum :- "We speak wisdom among the full-grown. 
. . But not unto you as unto the spiritual, but as unto the carnal, unto babes in Christ, feeding you with milk, not with meat, being not yet able to receive it."

For these, then,- the uninstructed and undeveloped,the Church must continue to speak with veiled face, in parable and symbol. Our appeal is to those who, having attained their intellectual and spiritual majority, have put away childish things, and who, accordingly,-instead of being content with the husk of the letter, and ignoring the spirit for the form, or limiting it by the form,- -are impelled by the very necessity of their nature to seek behind the veil and to read the spirit through the form, that "with unveiled face they may behold the glory of the Lord, and be transformed into the same image." They who are thus ripe will in these pages learn what is the Reality which only Mind can apprehend; and will understand that it belongs not to the objective and phenomenal plane of mundane history, but to the subjective and noumenal plane of their own souls, where seeking they will find enacted the process of Fall, Exile, Incarnation, Redemption, Resurrection, Ascension, the coming of the Holy Spirit, and-as the sequel-the attainment of Nirvâna, the "peace that passeth understanding." For those thus initiated the mind is no longer concerned with history; the phenomenal becomes recognised as the illusory, - a shadow projected by the Real, having no substance in itself, and an accident only of the Real. One thing is and abides,-the Soul in man,-Mother of God, immaculate; descending-as Eve -into matter and generation; assumed-as Mary-beyond 
matter into life eternal. One state, supreme and perfect, epitomises and resolves all others;-the state of Christ, promised in the dawn of evolution; displayed in its process; glorified at its consummation. To realise the assumption of Mary, to attain to the stature of her Son,these ends and aspirations constitute the desire of the illuminate. And it is in order to indicate them anew and the method of seeking them intelligently, that this book is written.

This preface may-it seems to us-fittingly conclude with a token of the estimation The Perfect Way has won from persons specially qualified to judge it. The following is selected from numerous communications to the like effect, coming, not only from various parts of the world, but from members of various nationalities, races and faiths, and showing that our book is already accomplishing far and wide its mission as an Eirenicon.

The veteran student of the "divine science," a reference to whom, as the friend, disciple, and literary heir of the renowned kabalist and magian, the late Abbé Constant ("Eliphas Levi "), will be for all initiates a sufficient indication of his personality, ${ }^{2}$ thus writes to us :-

"As with the corresponding Scriptures of the past, the appeal on behalf of your book is, really, to miracles : but with the difference that in your case the miracles are in-

3 The reference is to Baron Giuseppe Spedalieri, a native of Sicily who resided at Marseilles, and who, Edward Maitland said, was "the ripest living veteran of spiritual science in Christendom" (Life of $A$. $K$., vol. ii., pp. 3 I, I54; Story of $A$. $K$. and E. M., p. 189). 
tellectual ones and incapable of simulation, being miracles of interpretation. And they have the further distinction of doing no violence to common sense by infringing the possibilities of Nature; while they are in complete accord with all mystical traditions, and especially with the great Mother of these,- the Kabbala. The miracles, such as I am describing, are to be found in The Perfect Way, in kind and number unexampled, they who are the best qualified to judge will be the most ready to affirm.

"And here, apropos of these renowned Scriptures, permit me to offer you some remarks on the Kabbala as we have it. It is my opinion,-

"( 1 ) That this tradition is far from being genuine, and such as it was on its original emergence from the sanctuaries.

"(2) That when Guillaume Postel-of excellent memory -and his brother Hermetists of the later middle age-the Abbot Trithemius and others-predicted that these sacred books of the Hebrews should become known and understood at the end of the era, and specified the present time for that event, they did not mean that such knowledge should be limited to the mere divulgement of these particular Scriptures, but that it would have for its base a new illumination, which should eliminate from them all that has been ignorantly or wilfully introduced, and should re-unite that great tradition with its source by restoring it in all its purity.

"(3) That this illumination has just been accomplished, and has been manifested in The Perfect Way. For in this book we find all that there is of truth in the Kabbala, sup- 
plemented by new intuitions, such as present a body of doctrine at once complete, homogeneous, logical, and inexpugnable.

"Since the whole tradition thus finds itself recovered or restored to its original purity, the prophecies of Postel, etc., are accomplished; and I consider that from henceforth the study of the Kabbala will be but an object of curiosity and erudition like that of Hebrew antiquities.

"Humanity has always and everywhere asked itself these three supreme questions:-Whence come we? what are we? whither go we? Now, these questions at length find an answer, complete, satisfactory, and consolatory, in The Perfect Way." 3

As the secrecy originally observed is, even were it still desirable, no longer practicable, we have added our names to the title-page.

Christmas, i 886.

${ }^{3}$ This judgment is irrespective of the mode of presentation, for any defects in which the responsibility rests with ourselves.

He subsequently wrote:--

"If the Scriptures of the future are to be, as I firmly believe they will be, those which best interpret the Scriptures of the past, these writings will assuredly hold the foremost place among them " (Life of $A$. $K$., vol. ii., p. 155 ; Story of $A . K$. and E. M., p. 190). 


\section{PREFACE TO THE FIRST EDITION.}

According to classical legend, the Goddess Athena had once for votary a fair virgin named Medusa, who, becoming vain of her beauty and weary of the pure service of the maiden Goddess, introduced folly and defilement into the very sanctuary of the Temple in which she was wont to worship. Thereupon a terrible fate overtook her. The beautiful face, which had been the cause of her fall, assumed an aspect so terrible as to blight and petrify all who looked upon it ; her tresses, once the chief object of her pride, were changed into vipers; and the hands which had ministered to heaven became as the talons of a bird of prey. Thus transformed into a Gorgon, she brought forth monsters, and for a time devastated the earth. At length the hero Perseus, "Son of God," commissioned by Athena and Hermes, and armed by them with wings and sword and shield, slew the terrible creature, and smote off her venomous head. This exploit-itself fraught with great perils-was followed by the achievement of another not less difficult. Andromeda, daughter of the Athiopian king, being doomed to become the prey of a Dragon which long had ravaged her father's 
coasts, was already chained to a rock on the seashore and on the point of being devoured, when Perseus-divinely guided to the scene of the intended sacrifice-vanquished the Dragon and delivered the princess. And, having won her love and espoused her, the son of Zeus bore her away from her father's kingdom into heaven, to shine for ever beside him, redeemed, immortal, and glorious.

Now, the names Medusa and Andromeda have a common root, and signify respectively "guardian" or "house" of Wisdom, and "the ruler" or " helpmeet" of Man. They are thus typical names, the first, of the Church, the second, of the Soul. And the two myths of which their bearers are the heroines, together constitute a prophecy-or perpetual verity-having special application to the present epoch. Medusa is that system which-originally pure and beautiful, the Church of God and the guardian of the Mysteries-has, through corruption and idolatry, become "the hold of every unclean thing," and the mother of a monstrous brood. And, moreover, like the once lovely face of Medusa, the Doctrine which bore originally the divine impress and reflected the Celestial Wisdom Herself, has-through the fall of the Church-become converted into Dogma so pernicious and so deadly as to blight and destroy the reason of all who come under its control. And the Perseus of the myth is the true Humanity - earth-born indeed, but heaven-begotten-which, endowed by Wisdom and Understanding with the wings of Courage, the shield of Intuition, and the sword of Science, is gone forth to smite and destroy the corrupt Church and 
to deliver the world from its blighting influence. But it is not enough that the Gorgon be slain. A task yet greater and more glorious awaits achievement. Andromeda, the Soul, the better part of Man, is on the point of being devoured outright by the baleful dragon of Negation, the agent of the lower nature, and the ravager of all the hopes of mankind. Her name-identical with the terms in which is described the first Woman of Hebrew story-indicates her as the helpmeet and ruler of man; her parentage denotes the origin of the Soul from the astral Fire or Æther, signified by the land of $\mathbb{E}$ thopis $;^{1}$ the brazen fetters with which she is bound to the rock, typify the present bondage of the Divine in man to his material part ; and her redemption, espousal, and exaltation by the hero Perseus, prefigure the final and crowning achievement of the Son of God, who is no other than the Spiritual Manhood, fortified and sustained by Wisdom and Thought. Of no avail against the monster which threatens to annihilate the Soul, are the old devices of terrorism, persecution, and thraldom by which the corrupt Church sought to subjugate mankind to her creed. The Deliverer of the Soul must be free as air, borne on the wings of a Thought that knows no fear and no restraint, and armed with the blade, two-edged and facing every way, of a will omnipotent alike for attack and defence, and with the rod of a perfect Science. He must be bent, not on destruction merely, but on salvation likewise; and his sword must be as apt to smite the fetters from the limbs of Andromeda, as to deal the stroke of death to the Gorgon. It is not enough 
that he carry to Olympus the dead Medusa's head; he must bear thither also a living Bride. His mission is not only to satisfy the Mind but to content the Heart. The Intellect - the "Man"-it is, who handles the sword of the liberator; and the Intuition-the "Woman"-it is, who weaves and constructs. But for her labour his prowess would be vain, and his deeds without goal or reward. The hero brings home his spoils to the tent, and hangs up his shield and spear by the hearth-fire. All honour to the warrior, alike as iconoclast, as scientist, as purifier of the earth. His work, however, is but initiatory, preparing the way and making the path straight for Her who carries neither torch nor weapon of war. By her is the intellect crowned; by her is humanity completed; in her the Son of Zeus finds his eternal and supreme reward; for she is the shrine at once of divinest Wisdom and of perfect Love.

It is thus evident that classical story, identical in substance with the allegorical prophecies of Hebrew and Christian scripture, exhibits the work of the Saviour or Liberator, as having a twofold character. Like Zeus the Father of Spirits, whose son he is, the Reason is at once Purifier and Redeemer. The task of Destruction accomplished, that of Reconstruction must begin. Already the first is well-nigh complete, but as yet no one seems to have dreamed of the last as possible. The present age has witnessed the decline and fall of a system which, after having successfully maintained itself for some eighteen centuries against innumerable perils of assault from without 
and of faction from within, has at length succumbed to the combined arms of scientific and moral criticism. But this very overthrow, this very demolition, creates a new void, to the existence of which the present condition of the world and the apprehensions and cravings everywhere expressed, bear ample testimony. On all sides men are asking themselves, "Who will show us any good?" To whom or to what, if the old system be fallen, shall we turn for counsel and salvation from Doom? Under what roof shall we shelter ourselves if the whole Temple be demolished, and "not one stone be left upon another that shall not be thrown down?" What way shall we take to Sion, if the old road be buried beneath the avalanche? Agnosticism and Pessimism have seized upon the best intellects of the age. Conscience has become eclipsed by self-interest, mind obscured by matter, and man's percipience of his higher nature and needs suppressed in favour of his lower. The rule of conduct among men is fast becoming that of the beast of prey:-self before all, and that the earthly, brutish, and ignoble self. Everywhere are the meaning and uses even of life seriously called in question; everywhere is it sought to sustain humanity by means which are in themselves subversive of humanity; everywhere are the fountains of the great deep of human society breaking up, and a deluge is seen to be impending, the height, extent, and duration of which no one can forecast. And nowhere yet is discernible the Ark, by taking refuge in which mankind may surmount and survive the flood.

Nevertheless this Ark so anxiously looked for, this Way 
so painfully sought, this work of Reconstruction so sorely needed, are all attainable by man. The certainty of their attainment is involved in the nature itself of existence, and ratified in every expression given to the mysteries of that nature from the beginning of the world.

The prime object of the present work is, then, not to demolish but to reconstruct. Already the needful service of destruction has been widely and amply rendered. The old temple has been thrown down and despoiled, and the "children of Israel" have been carried away captive to "Babylon,"-the mystic name of the stronghold of Materialism. As it is written; "The vessels of the House of the Lord"- that is, the doctrines of the Church-"great and small, and the treasures of the Temple and of the King and of the princes, were carried away to Babylon. And the enemies set fire to the House of God, and broke down the wall of Jerusalem,"-that is, the Soul,- "and burnt all her towers, and whatsoever was precious they destroyed."

Time it is now for the fulfilment of the second and last act of the prophetical drama;-

"Thus saith Cyrus,"-that is, Kúpios, the Lord, the Christ ; - "All the Kingdoms of the earth hath the God of heaven given me, and $\mathrm{He}$ hath charged me to build Him again a House in Jerusalem." "Who is there of you, who will go up and build again the Temple of the Lord God of Israel?"

In these words is expressed the intention of the writers of this book. And if they have preferred to withhold their 
names, it is neither because they distrust the genuineness of their commission or the soundness of their work, nor because they shrink from the responsibility incurred; but in order that their work may rest upon its own merits and not upon theirs, real or supposed;-in order, that is, that it may be judged, and not pre-judged one way or the other. Such reservation is in accordance with its whole tenour. For the criterion alone to which appeal is made on its behalf is the Understanding, and this on the ground that it is contrary to the nature of Truth to prevail by force of authority, or of aught other than the understanding; since Truth-how transcendent soever it be-has its witness in the Mind, and no other testimuny can avail it. If truth be not demonstrable to mind, it is obvious that man, who is essentially mind, and the product of mind, cannot recognise or appropriate it. What is indispensable is, that appeal be made to the whole mind, and not to one department of it only.

In this bouk no new thing is told; but that which is ancient-so ancient that either it or its meaning has been lost - is restored and explained. But, while accepting neither the presentations of a conservative orthodoxy, nor the conclusions of a destructive criticism, its writers acknowledge the services rendered by both to the cause of Truth. For, like the Puritans who coated with plaster and otherwise covered and hid from view the sacred images and decorations which were obnoxious to them, orthodoxy has at least preserved through the ages the symbols which contain the Truth, beneath the errors with which it has 
overlaid them. And criticism, however fiercely infidel, has, by the very act of destruction, cleared the way for rebuilding. It has fulfilled the man's function,-that of analysis, and made possible the woman's, - that of synthesis. And this is according to the Divine order.

In both nature and method, therefore, this book is mainly interpretative, and, consequently, reconciliatory. And it is this, not only in respect of the Hebrew, Christian, Oriental, and Classic systems in particular, but in respect also of modern thought and human experience in general. It aims at making at-one-ment between Mind and Heart by bringing together Mercy-that is, Religion-and Truththat is, Science. It seeks to assure man that his best and most powerful friends on every plane are Liberty and Reason, as his worst enemies are Ignorance and Fear; and that until his thought is free enougl $\_$and strong enough to bear him aloft to "heaven," as well as to "the lowermost parts of the earth," he is no true Son of Hermes, whose typical name is Thought, and who yet is, in his supremest vocation, the Messenger and Minister of God "the Father."

AdVent, 188I. 


\section{ABSTRACT OF ARGUMENT AND CONTENTS.}

PREFACE TO THE FOURTH EDITION pp. $i-x$ - $l i x$

PREFACE TO THE SECOND (REVISED)

EDITION . . . . . . pp. l-lxii

PREFACE TO THE FIRST EDITION pp. lxiii-lxx

LECTURE THE FIRST.

INTRODUCTORY.

Part I. Purpose of this book, to supply the existing need of a perfect system of thought and life by one founded in the nature of existence. This not a new invention, but a recovery of the original system which was the basis of all religions. Its recovery due to the same means by which it was originally received, namely, the Intuition, which represents the knowledges acquired by the Soul in its past existences, and complements the intellect, being itself quickened and enhanced 
by illumination of the Spirit. Revelation a proper prerogative of man, belonging to him in virtue of his nature and constitution, and crowning the reason. God the supreme Reason. The Understanding, the "Rock" of the true Church. Illustrations of Method, classic and rabbinical. Sketch of Doctrine. Spirit and Matter : their nature, relations, and essential identity. Existence and Being. The Kalpa, Sabbath, and Nirvâna. Divinity of Substance : its unity and trinity, and mode of individuation and development. The true doctrine of creation by evolution; found in all religions, as also that of the progression and migration of Souls; personal and historical testimony to its truth; recognised in Old and New Testaments. Rudimentary man. The Sphinx . . . . . pp. 1-25

PART II. Relation of the system recovered to that in possession. The true heir. Religion, being founded in the nature of existence, is necessarily non-historical, independent of times, places, and persons, and appeals perpetually to the mind and conscience. Objections anticipated. Persistency of religious ideas due to their reality. The apparently new not necessarily really new. Christianity not exempt from the influences which caused 
the deterioration of Judaism. Its future development by means of new revelation foretold by its Founder. Need of such new revelation to preserve, not only religion, but humanity from extinction. The "man of sin" and "abomination that maketh desolate." Substitution of Gospel of Force for Gospel of Love. One name whereby is salvation, but many bearers. The Christs . pp 25-37

\section{LECTURE THE SECOND.}

THE SOUL; AND THE SUBSTANCE OF EXISTENCE

Part I. The Soul, universal or individual, the supreme subject and object of culture : the essential self, to know which is the only wisdom, involving the knowledge of God. Mysticism or Spiritualism, and Materialism, the doctrines respectively of Substance or Spirit, and of Phenomenon. Matter a mode or condition of Spirit, and indispensable to its manifestation. The object of all religion and subject of all revelation the redemption of Spirit from Matter. Necessity to creation of the idea of a no-God. The ascent from Nature's Seeming to God's Being. The recovered system and Materialism respectively as Phoibos and Python . . . . pp. $3^{8-44}$ 
PART II. The Soul as individual, its genesis and nature : as the divine idea, eternal in its nature, yet perishable if uninformed of the Spirit. The "Fire of the hearth:" the Divine breath. Convergence and divergence: the celestial Nirvâna, and that of annihilation. The end of the persistently evil. The planet and its offspring. The fourfold nature of existence, alike in macrocosm and microcosm, due to differentialities of polarisation of original substance

. pp. $44-50$

Part III. The Soul as individual, its history and progress: commencing in the simplest organisms, it works upwards, moulding itself according to the tendencies encouraged by it; its final object to escape the need of a body and return to the condition of pure Spirit. Souls various in quality. The parable of the Talents .

PART IV. Of the nature of God; as Living Substance, One; as Life and Substance, Twain; the Potentiality of all things; the absolute Good, through the limitation of whom by Matter comes evil. Subsists prior to creation as Invisible Light. As Life, God is $\mathrm{He}$; as Substance, She; respectively the Spirit and Soul universal and individual; the Soul the 
ABSTRACT OF ARGUMENT AND CONTENTS. IXxv

feminine element in man, having its representative in woman. God the original, abstract Humanity. The Seven Spirits of God. "Nature." The heavenly Maria, her characteristics and symbols. As Soul or Intuition, she is the "woman" by whom man attains his true manhood. The defect of the age in this respect. No intuition, no organon of knowledge. The Soul alone such an organon - pp. $5^{2-5^{8}}$

PART V. Divine Names, denotive of characteristics. Function of religion to enable man to manifest the Divine Spirit within him. Man as an expression of God. The Christs, why called Sungods. The Zodiacal planisphere a Bible or hieroglyph of the Soul's history. Bibles, by whom written. The "Gift of God" . . . . . . pp. $5^{8-63}$

\section{LECTURE THE THIRD.}

THE VARIOUS ORDERS OF SPIRITS; AND HOW TO DISCERN THEM.

Part I. The sphere of the astral, its four circuli and their respective occupants. The Shades; purgatory ; "hell"; "devils"; "the Devil"; possession by devils; "souls in prison"; 
"under the elements"; spirits of the elements, subject to the human will; souls of the dead; the anima bruta and anima divina. Metempsychosis and reincarnation; conditions of the latter ; descent to lower grades ; cause of the Soul's loss . . . . . . pp. 64-75

PART II. The astral or magnetic spirits by which, ordinarily, "mediums" are "controlled"; reflects rather than spirits; difficulty of distinguishing them from Souls; elements of error and deception; delusive character of astral influences ; their characteristics ; danger of a negative attitude of mind; necessity of a positive attitude for Divine communication; spirits elemental and elementary; genii loci; cherubim

PART III. The sphere of the celestial ; the procession of Spirit; the triangle of life; the Genius or guardian angel, his genesis, nature, and functions ; the Gods, or Archangels . pp. 85-93

\section{LECTURE THE FOURTH.}

THE ATONEMENT.

PART I. This the central doctrine of religion, and, like the Kosmos, fourfold in its nature. 
What the doctrine is not; its corruption by materialism ; priestly degradation of the character of Deity. The Bible represents the conflict between prophet and priest, the former as the minister of the intuition, and the latter as the minister of sense . . pp. 94-99

PART II. The occult side of the sacrificial system. Effusion of blood efficacious in the evocation of sub-human spirits, as shown by various examples. These spirits visible in the fumes of the sacrifices. Astral spirits personate the celestials. Abhorrence of the true prophet for bloodshed, illustrated in Buddha's rebuke to the priests. The orthodox doctrine of vicarious atonement, a travesty, due to astral spirits, of the true doctrine. Pernicious effects of the use of blood (or flesh) for food; impossibility, on such diet, of attaining full perception of divine truth . . . pp. 99-105

PART III. Antiquity and universality of the Cross as the symbol of Life physical and spiritual. Its application to the doctrine of the Atonement fourfold, having a separate meaning for each sphere of man's nature. Of these meanings the first is of the physical and outer, denoting the crucifixion or rejection of the Man of God by the world. The 
second is intellectual, and denotes the crucifixion or conquest in man of his lower nature. The third, which refers to the Soul, implies the passion and oblation of himself, whereby the man regenerate obtains the power-by the demonstration of the supremacy of Spirit over matter-to become a Redeemer to others. The Fourth appertains to the Celestial and innermost, and denotes the perpetual sacrifice of God's Life and Substance for the creation and salvation of His creatures. The pantheistic nature of the true doctrine . pp. 105-117

\section{LECTURE THE FIFTH.}

THE NATURE AND CONSTITUTION OF THE EGO.

PART I. Psyche as the Soul and true Ego the result of Evolution, being individualised through Matter . . . . . pp. II8-123

PART II. Man's two personalities. Karma, or the results of past conduct and consequent destiny. The soul essentially immaculate . . pp. 123-124

PART III. The Ego more than the sum total of the consciousnesses composing the system, as representing these combined and polarised to a higher plane. The Psyche alone subjective and capable of knowledge . . . pp. 125-135 
Part IV. The Shade, the Ghost, and the Soul, their respective natures and destinies . pp. I35-139

Part V. The Anima Mundi, or Picture-World. The soul of the planet, like that of the individual, transmigrates and passes on . pp. 139-141

PART VI. The Evolution of the Ego, and therein of the Church of Christ, implied in the dogmas of the Immaculate Conception and the Assumption of the B.V.M. .

- pp. 141-144

\section{LECTURE THE SIXTH.}

\section{THE FALL (No. I.).}

PART I. The first Church; its type the Kaabeh, or cube, denoting sixfoldness; dates from "Paradise." The Merkaba, or vehicle of God, drawn by the four elements. The four rivers of Eden. Allegorical character of the Mystic Scriptures; how recovered by Esdras ; their origin and corruption . . . pp. 145-153

PART II. The Parable of the Fall: its signification fourfold, being one for each sphere of existence ; the first, physical and social pp. 154-161

PART III. The second signification rational and philosophical; the third, psychic and personal . . . . . . . pp. 161-166 
Part IV. The fourth signification spiritual and kosmical. The Restoration implied in the Sabbath, and prophesied in the Zodiac, and in the arms of Pope Leo XIII. . . pp. 166-I 7 I

Part V. A new Annunciation . . . pp. 172-175

\section{LECTURE THE SEVENTH.}

THE FALL (No. II.).

PART I. Interpretation of Scripture dual, intellectual and intuitional, or exterior and interior; the Soul as the Woman, through whose aspiration to God man becomes Man in the mystic sense, and made in the image of God; and through whose inclination to Matter he falls from that image. As the Fall is through loss of purity, so the Redemption is through restoration of purity . . pp. 176-187

PART II. The Soul's history as allegorised in the books of Genesis and Revelation . pp. 187-194

PART III. Source of errors of Biblical interpretation. The historical basis of the Fall. The Church as the Woman. Rise and Fall of original Church. A primitive mystic community. The source of doctrine, interior and superior to priesthoods . . . pp. 194-204 
PART IV. Nature and method of historical Fall. The three steps by retracing which the Restoration will come. Tokens of its approach . . . . . . pp. 204-209

\section{LECTURE THE EIGHTH.}

THE REDEMPTION.

PART I. The "great work" the Redemption of Spirit from Matter: first in the individual, next in the universal. Definition of mystic terms used to denote the process : "Passion," "Crucifixion," "Death," "Burial," "Resurrection," "Ascension" . . . . pp. 210-217

PART II. The Man perfected and having power: the "philosopher's stone," and kindred terms; the Adept and the Christ; sense in which the latter may be called a medium for the Highest; not as ordinarily understood: the Hierarch or Magian, his qualifications and conditions . . . . . . . pp. 217-224

Part III. Design of the Gospels to present perfect character of Man Regenerate; selection of Jesus as subject ; Church's failure of comprehension through loss of spiritual vision, due to Materialism. Answer to objection. 
Jesus as Liberator necessarily spiritual ; Paul's view. Method of Gospel symbolism; the miracles ; kosmic order of Gospels . pp. 225-232

PART IV. Parentage of the Man Regenerate. Joseph and V. Mary as representatives of Mind and Soul. The two Josephs. Catholic tradition and hagiology. Mary Magdalen as type of Soul; also the Seven Apocalyptic Churches. Identification of the Magi; the Stable and Cave of the Nativity. The John Baptist within. The Acts of the B.V.M. Ascension and Assumption. Final State of Soul . . . . . . . pp. 232-244

Part V. The Twelve Gates of the Heavenly Salem; the Tabernacle; the Round Table and its "bright Lord;" the Number of Perfection; the genealogy of the Man Regenerate; "Christ" no incarnate God or angel, but the highest human. The world's present condition due to sacerdotal degradation of truth. Christian Gospels represent later stages only of regeneration, the earlier ones having been exemplified in the systems of Pythagoras and Buddha. Christianity framed with direct reference to these, not to supersede but to complete them; Buddha 
and Jesus being necessary to each other, as head and heart of same system. Of these combined will be produced the Religion and Humanity of the future; hence the import of the connection between England and the East. The Transfiguration, a prophecy. "Abraham, Isaac, and Jacob," their relation to the mysteries of Brahma, Isis and Iacchos. The "Kings of the East." The "Eastern Question "; its interior significance ; the destiny of Islamism . . . . . . pp. 244-257

\section{LECTURE THE NINTH.}

GOD AS THE LORD; OR, THE DIVINE IMAGE.

PART I. The two modes of Deity; God as the Lord, in the Bible, the Kabbala, and the Bhagavad Gîtâ. Swedenborg and his doctrine : his limitations and their cause. The Hermetic doctrine. The "Mount of the Lord." True meanings of "Mystery"; sacerdotal degradation of the term, and its evil results . . . . . . . pp. 258-264

PART II. Function of the Understanding in regard to things spiritual. Its place in the systems human and divine. The "Spirit of Understanding," his various names and 
symbols, and relation to the Christ. Cognate myths in illustration. Hermes as regarded by the Neoplatonists and by modern Materialists. Mystic and Materialist, the feud between them. The School of Torturers. The "Mystery of Godliness," according to the Kabbala and Paul. The Pauline doctrine concerning Woman; its contrast with the doctrine of Jesus. Woman according to Plato, Aristotle, Philo, the Fathers, the Church, the Reformation, Milton, Islamism, and Mormonism . . . . . pp. 264-282

PART III. Charges whereby it is sought to discredit the system of the Mystics; Plagiarism and Enthusiasm : the signification and value of the latter. Ecstasy: its nature and function. Mystics and Materialists, their respective standpoints. Conspiracy of modern science against the Soul. Materialists, ancient and modern, contrasted . . . pp. 282-291

PART IV. Man's perception of God sensible as well as mental. The divine Unity, Duality, Trinity, and Plurality. The Logos, or Manifestor. The mystery of the human Face pp. 29I-295

Part V. The Vision of Adonai . pp. 296-299 
ABSTRACT OF ARGUMENT AND CONTENTS. lxxxv

PART VI. "Christ" as the culmination of

Humanity and point of junction with Deity.

The Credo of the Elect . . . pp. 299-302

\section{APPENDICES.}

I. The Constitution of Existence: Its Nature

PAGE AND UNITY

(Being Lecture V. of the First Edition).

II. ParagraphS 27 TO 41 OF Lecture Vili. of the SECOND Edition . . . . . . . 327

I11. "The Perfect Way" and Its Critics - 340 INDEX . . . . . . . . . . 359 



\section{ILLUSTRATIONS.}

LECTURES.

Fig. I. The Cherubim of Ezekiel and the Apocalypse $\begin{array}{r}\text { PAGE } \\ \text { I } 47\end{array}$

FIG. 2. The Tabernacle in the Wilderness . . . . 246

\section{APPENDICES.}

FIG. 3. Schematic Section of the Typical Organic Cell . 3II

Fig. 4. Schematic Section of the Typical Wandering Cell 316

FIG. 5. Break-up of Fixed Cell . . . . . . 316

Figs. 6, 7, 8. Schemata showing the Magnetic Molecular

Poles in Health and in Disease (Sections). $\quad 325$

FIG. 9. Section of the Great Pyramid of Gizeh . . 334

FIG. 10. The Marriage of the Hierophant . . . 337 


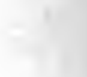

in
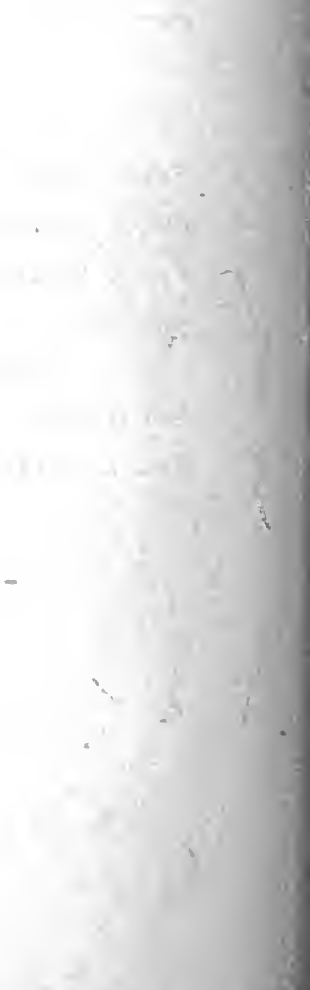
"And the Lord God said unto the serpent . . I I will put enmities between thee and the woman, and between thy seed and her seed : she shall crush thy head, and thou shalt lie in wait for her heel."-Gen. iii. 14, 15.

"And a great sign appeared in heaven: a woman clothed with the sun, and the moon under her feet, and on her head a crown of twelve stars." $-A p o c$. xii. I. 

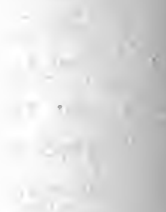

$1+2+2$
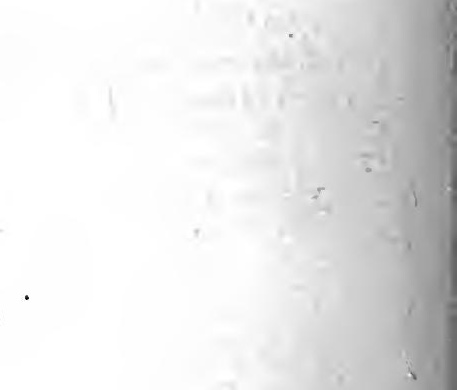

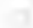
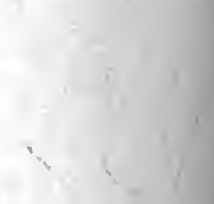

n

and
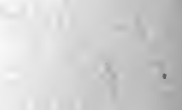


\section{THE PERFECT WAY; \\ or, \\ THE FINDING OF CHRIST.}

LECTURE THE FIRST. ${ }^{1}$

INTRODUCTORY.

PART I.

I. The purpose of the Lectures, of which this is the first, is the exposition of a system of Doctrine and Life, at once scientific, philosophic, and religious, and adapted to all the needs and aspirations of mankind. This system is offered in substitution, on the one hand, for that traditional and dogmatic Conventionalism which, by its failure to meet the tests of science and to respond to the moral instincts, is now by thoughtful persons nearly or wholly discarded; and, on the other hand, for that agnostic Materialism which is rapidly overspreading the world to the destruction of all that is excellent in the nature of man.

2. But although offered in substitution both for that which experience has shown to be defective, and that which

1 This lecture was delivered by Anna Kingsford on Monday the 16th May, 1881. Paragraphs $1-6 ; 14-18 ; 22-24 ; 30-32 ; 52,53$ and 55 were written by Edward Maitland: and paragraphs $7-13 ; 19-21 ; 26-$ $29 ; 43-51 ; 54$ and 56 were written by Anna Kingsford (Life of $A$. K., vol. ii., pp. 16, 17, 32). 
is so recent as to be only now in course of reception, the system to be proposed is not itself new; and its present exposition represents, not an Invention as ordinarily understood, but a Restoration. For, as will be shown indubitably, there has been in the world from the earliest ages a system which fulfils all the conditions requisite for endurance; a system which, being founded in the nature of Existence itself, is eternal in its truth and application, and needs but due understanding and observance to enable man by means of it to attain to the highest perfection and satisfaction he can by any possibility imagine or desire. And, as also will be shown, this system is no other than that which all the great religions of the world have, under various guises and with varying degrees of success, striven to express.

3. Our object, therefore, is to restore and rehabilitate the Truth, by divesting it of all the many limitations, degenerations, perversions, and distortions to which throughout the ages it has been subjected; and by explaining the real meaning of the formulas and symbols which thus far have served rather to conceal than to reveal it. That which we shall propound, therefore, will be no new doctrine or practice; but that only which is either so old as to have become forgotten, or so profound as to have escaped the superficial gaze of modern eyes.

4. Now, in order to be entitled to a hearing in respect of a subject thus momentous and recondite, it is obviously necessary that the claimant should be able to plead some special qualification in the shape of the possession either of an exclusive source of information, or of an unusual faculty. Hence it becomes necessary to include in these introductory remarks an account of the qualification relied on in the present instance.

5. That which is thus claimed is at once a faculty and 
a source of information, and is, in these days, of rare though not novel occurrence. It is that mode of the mind whereby, after exercising itself in an outward direction as Intellect, in order to obtain cognition of phenomena, it returns towards its centre as Intuition, and by ascertaining the essential idea of the fact apprehended through the senses, completes the process of its thought. And just as only by the combined and equal operation of the modes termed centrifugal and centripetal, of force, the solar system is sustained; so only by the equilibrium of the modes, intellectual and intuitional, of the mind, can man complete the system of his thought and attain to certitude of truth. And as well might we attempt to construct the solar system by means of an exercise of force in one direction, the human system by means of one sex, or the nervous system by means of one kind of roots only, as to attain to knowledge by means of one mode only of mind. It is, however, precisely in this manner that the materialistic hypothesis errs; and by its error it has forfeited all claim to be accounted a system.

6. The Intuition, then, is that operation of the mind whereby we are enabled to gain access to the interior and permanent region of our nature, and there to possess ourselves of the knowledge which in the long ages of her past existences the Soul has made her own. For that in us which perceives and permanently remembers is the Soul. And inasmuch as, in order to obtain her full development, she remains for thousands of years in connection, more or less close, with Matter, until, perfected by experience of all the lessons afforded by the body, she passes on to higher conditions of being; it follows that no knowledge which the race has once acquired in the past can be regarded as hopelessly lost to the present. 
7. But the memory of the soul is not the only factor in spiritual evolution. The faculty which we have named the Intuition, is completed and crowned by the operation of Divine Illumination. Theologically, this illumination is spoken of as the Descent of the Holy Spirit, or outpouring of the heavenly efflux, which kindles into a flame in the soul, as the sun's rays in a lens. Thus, to the fruits of the soul's experience in the past, is added the "grace" or luminance of the Spirit;-the baptism of Fire which, falling from on high, sanctifies and consummates the results of the baptism of Water springing from the earth. 'To be illumined by this inward Light, to be united with this abiding divinity, was ever the ardent aspiration of the seeker after God in all times and of all lands, whether Egyptian Epopt, Hindû Yogee, Greek Neoplatonist, Arab Sufi, or Christian Gnostic. By the last named it was styled the Paraclete and Revealer, by whom man is led into all truth. With the Hind 0 it was Atman, the All-seeing, not subject to rebirths like the soul, and redeeming from the vicissitudes of destiny. By the combined operation of this Light, and the enhancement it effects in the intuitions of the soul,enabling her to convert her knowledge into wisdom,- - the human race has been from age to age perpetually carried up to higher levels of its evolution, and will in due course be enabled to substantialise in itself and to be all that in the past it has known and desired of perfection.

8. These Lectures, then, represent the result of intuitional memory, quickened and enhanced, we believe, by some measure of the divine influx, and developed by the only mode of life ever found compatible with sound philosophic aspirations. And of the doctrine we seek to restore, the basis is the Pre-existence and Perfectibility of the Soul. The former, because, but for her persistence, progressive 
genesis, or gradual becoming, would be impossible. For development depends upon memory, and is the result of the intelligent application of knowledge gained by experience, in satisfaction of the needs of the individual; the sense of need being complemented by a sense of power.

And the Perfectibility; because, as a portion of the Divine Being-which is God-constituted of the Divine Substance and illumined by the Divine Spirit, she, the Soul, is necessarily capable of all that her nature implies; and competent to realise for the individuality animated by her, the injunction of the great Master of mystical science; "Be ye perfect, as your Father in heaven is perfect."

9. It is necessary for the elucidation of our system to speak yet further of the constitution of man. Concerning this, our doctrine is that which has prevailed from the earliest times, and in all philosophical religions. According to this doctrine, man is possessed of a fourfold nature, a speciality which differentiates him from all other creatures. The four elements which constitute him are, counting from without inwards, the material body, the fluidic perisoul or astral body, the soul or individual, and the spirit, or divine Father and life of his system. This last it is whose kingdom is described as the leaven taken by the woman-the divine Sophia or Wisdom-and hidden in three measures of meal, namely, the soul, the perisoul, and the body, until the whole is leavened; until, that is, the whole man is so permeated and lightened by it that he is finally transmuted into Spirit, and becomes "one with God."

10. This dectrine of the fourfold nature of man, finds expression also in the Hebrew Scriptures, being symbolised by the four rivers of Eden-or human nature-flowing from one source, which is God; and by the four elemental living 
beings of Ezekiel, and their four wheels or circles, each of which denotes a region and a principality or power. It has its correspondence also in the four interpretations of all mystical Scriptures, which are the natural, the intellectual, the ethical, and the spiritual; and also in the unit of all organic existence, the physiologic cell. For this, as the student of Histology knows, is composed, from without inwards, first of cell-membrane or capsule, which is not a separable envelope, but a mere coagulative sheathing of its fluidic part ; secondly, of the protoplasmic medium; thirdly, of the nucleus, itself a mode of protoplasmic substance; and, lastly, of an element not present in all cells, and often when present difficult to perceive, namely, the nucleolus, or inmost and perfectly transparent element. Thus does man, as the Microcosm of the Macrocosm, exemplify in every detail of his system the fundamental doctrine of the famous Hermetic philosophy by which the expression of every true Bible is controlled, the doctrine, namely, of Correspondence.

"As is the outer, so is the inner; as is the small, so is the great: there is but one law; and He that worketh is One. Nothing is small, nothing is great in the Divine Economy."

II. In these words are contained at once the principle of the universe and the secret of the Intuition. She it is, the Divine woman of man's mental system, that opens to him the "perfect way," the "way of the Lord," that "path of the just which, as a shining light, shineth more and more unto the perfect day." And her complete restoration, crowning, and exaltation, is the one condition essential to that realisation of the ideal perfection of man's nature, which, mystically, is called the "Finding of Christ."

12. Now, the modes whereby the Intuition operates are 
two, namely, Perception and Memory. By the former, man understands and interprets; by the latter he retains and utilises. Perceiving, recollecting, and applying, the mind enacts for itself a process analogous to that which occurs in the physical organism. For its operations correspond to the three physiological processes of Nutrition,-prehension, digestion, and absorption.

13. When the uninitiate person, or materialist, denies positively, as, with curious inconsistency, such persons do deny, the possibility of positive knowledge, and declares that "all we know is, nothing can be known," he speaks truly so far as concerns himself and his fellowes. "The natural man," as the apostle declares, "perceiveth not the things that are of the Spirit, for they are foolishness unto him; and he cannot know them because they are spiritually discerned. But the spiritual man judgeth all things, and he himself is judged of no man." While the two orders here indicated refer to the inner and outer, or soul and body, of each individual, they refer also to the two great divisions of mankind,- - they who as yet recognise the body only, and they who are so far unfolded in their interior nature as to recognise the soul also. Of these last is the initiate of sacred mysteries. Following his intuition, such a one directs the force of his mind inwards, and-provided his will is subordinated to and made one with the Divine will-passes within the veil, and knows even as he is known. For, as the apostle says again, "What man knoweth the things of a man, save the man himself? So likewise, the things of God no man knoweth, save the Spirit of God within the man. And the Spirit knoweth all things and revealeth them unto the man." As thus by means of our Divine part we apprehend the Divine, no such apprehension is possible to him who does not, in some degree, reflect the Divine 
image. "For if thine eye be evil, thy whole body is full of darkness. If then the very means of light in thee be darkness, how great is that darkness!"

14. Matter is the antithetical ultimate of Spirit. Wherefore the enemy of spiritual vision is always Materiality. It is therefore by the dematerialisation of himself that man obtains the seeing eye and hearing ear in respect of Divine things. Dematerialisation consists, not in the separation of the soul from the body, but in the purification of both soul and body from engrossment by the things of sense. It is but another example of the doctrine of correspondence. As with the vision of things physical, so with that of things spiritual. Purity alike of instrument and medium is indispensable to perception.

15. This then is the nature and function of the Intuition. By living so purely in thought and deed as to prevent the interposition of any barrier between his exterior and his interior, his phenomenal and his substantial self; and by steadfastly cultivating harmonious relations between these two,-by subordinating the whole of his system to the Divine central Will whose seat is in the soul,-the man gains full access to the stores of knowledge laid up in his soul, and attains to the cognition alike of God and of the universe. And for him, as is said, "there is nothing hid which shall not be revealed."

16. And it is not his own memory alone that, thus endowed, he reads. The very planet of which he is the offspring, is like himself, a Person, and is possessed of a medium of memory. And he to whom the soul lends her ears and eyes, may have knowledge not only of his own past history, but of the past history of the planet, as beheld in the pictures imprinted in the magnetic light whereof the planet's memory consists. For there are actually ghosts of 
events, manes of past circumstances, shadows on the protoplasmic mirror, which can be evoked.

17. But beyond and above the power to read the memory of himself or of the planet, is the power to penetrate to that innermost sphere wherein the soul obtains and treasures up her knowledge of God. This is the faculty whereby true revelation occurs. And revelation, even in this its highest sense, is, no less than reason, a proper prerogative of man, and belongs of right to him in his highest and completest measure of development.

18. For, placed as is the soul between the outer and the inner, mediator between the material and the spiritual, she looks inwards as well as outwards, and by experience learns the nature and method of God; and according to the degree of her elevation, purity, and desire, sees, reflects, and transmits God. It is in virtue of the soul's position between the worlds of substance and of phenomenon, and her consequent ability to refer things to their essential ideas, that in her, and her alone, resides an instrument of knowledge competent for the comprehension of Truth even the highest, which she only is able to behold face to face. It is no hyperbole that is involved in the saying, "The pure in heart see God." True, the man cannot søe God. But the Divine in man sees God. And this occurs when, by means of his soul's union with God, the man becomes "one with the Father," and beholds God with the eyes of God.

19. That is not really knowledge which is without understanding. And the knowledge acquired by man through the soul, involves the understanding of all the things apprehended. Now, to understand a thing, is to get intellectually into, beyond, and around it; to know the reason of and for it ; and to perceive clearly that it, and it only under the circumstances, is and could by any possi- 
bility be true. Apart from such knowledge and understanding, belief is impossible. For that is not belief, in any sense worthy of the term, which is not of knowledge. And only that belief saves which is conjoined with understanding. For the Rock on which the true Church is built is the Understanding.

20. Such is the meaning of the words of Jesus on the memorable occasion of Peter's confession of him. It was not to the man Simon that was applied the apostrophe,"Thou art Peter, the rock, and upon this rock will I build my Church;" but to the eternal and immutable Spirit of Understanding, by means of which the disciple had "found Christ." Thus the utterance of Jesus had reference, not to the man, but to the Spirit who informed the man, and whom with his spiritual eyes the Master discerned.

2I. We have said that the soul, with the eyes of understanding, looks two ways, inwards as well as outwards. It is interesting to remember that this characteristic of the soul was typified under the image of the two-faced divinity, Janus Bifrons, or, as called by Plutarch, Iannos. Now Janus is the same as Jonas. Wherefore it is said that Simon, the expositor of the true doctrine, is the son of Jonas, meaning the Understanding. Janus is also the door-keeper, as is Peter in Catholic tradition. And for this reason a door is called janua, and the first month or entrance of the year, January. Janus thus came to be regarded, like Peter, as the elder, the renewer of time, and the guardian of the outermost circle of the system, and one therefore with Saturn. And as the former was called Pater Janus, so the latter was called Peter Jonas, the Rock of Understanding. And he is represented, as also is Peter, standing in a ship, and holding in one hand a staff, and in the other a key. By this is signified, that to the Under- 
standing, born of the experiences of Time, belong the Rod of the Diviner-or the power of the Will-and the Keys of the Kingdom of Heaven. Wherefore the real chief of the apostles in the true Church-that which, by its knowledge of the mysteries of existence, alone can open the gates of eternal life-is the Understanding.

22. The priesthoods, materialising, as is their wont, divine things, have applied the utterance of Jesus to the man Simon and his successors in office; but with the most disastrous consequences. For, ignoring the understanding, and putting asunder that which God has joined together,-Faith and Reason,-they have made something other than Mind the criterion of truth.

To this divorce between the elements masculine and feminine of man's intellectual system, is due the prevailing unbelief. For, converted thereby into superstition, religion has been rendered ridiculous; and instead of being exhibited as the Supreme Reason, God has been depicted as the Supreme Unreason. Against religion, as thus presented, mankind has done well to revolt. To have remained subject, had been intellectual suicide. Wherefore the last person entitled to reproach the world for its want of faith, is the Priest; since it is his degradation of the character of God that has ministered to unbelief. Suppressing the "woman," who is the intuition, by putting themselves in her place, the priests have suppressed also the man, who is the intellect. And so the whole of humanity is extinguished. Of the influences under which Sacerdotalism has acquired its evil repute, a full account will appear as we proceed.

23. In these lectures, then, the practice denounced will be exchanged for the original method of all true Churches; and appeal will be made to that consensus of all the facul- 
ties, sensible, intellectual, moral, and spiritual, comprised in the constitution of man, wherein consists Common Sense. It is not upon any authority of book, person, tradition, or order, that we ourselves rely, or that we invite the attention of others. Reference will indeed be made, as already, to various sacred and other sources, but only for illustration, interpretation, or confirmation. For, confident in the knowledge that all things have their procession from Mind, and that consequently Mind is competent for the comprehension of all things; and also that Mind is eternally one and the same;-we have no fear of antagonism between the perceptions of the present and those of the past, however remote that past be. Only, let it be remembered, the appeal is, in all cases, to perception, and in no case to prejudice or convention. In proceeding from God, all things proceed from pure Reason; and only by Reason which, in being unwarped by prejudice and unobscured by Matter, is pure, can anything be rightly apprehended.

24. Hence it is that the disposition which refers everything, for instance, to a book, and this perhaps one arbitrarily selected from among many similar books; or that refuses to accept truth save on the authority of miracle, is a superstitious disposition, and one that opposes as insuperable a barrier to knowledge as does the materialismno less superstitious-which, constructing an hypothesis independently of facts, rejects all evidence which conflicts with its hypothesis. It is precisely a materialism such as this which, in the recoil from superstition of one kind, has plunged the age headlong into superstition of another kind. For the cultus of the present day - that of Matter-is the most stupendous example of Fetish-worship the world has ever seen. But of this we shall have more to say further 
on. It is necessary here but to remind those who worship a book, that things are not true because they are in a Bible; but that they are in a Bible because previously recognised as true. And miracles-which are natural effects of exceptional causes-may indeed be proofs of occult power and skill, but are no evidences of the truth of any doctrine.

25. The following story from the Talmud will serve both to lighten our lecture and to illustrate our position in this respect.

"On a certain day, Rabbi Eliezer ben Orcanaz replied to the questions proposed to him concerning his teaching; but his arguments being found to be inferior to his pretensions, the doctors present refused to admit his conclusions. Then Rabbi Eliezer said: 'My doctrine is true, and this karoub-tree which is near us shall demonstrate the infallibility of my teaching.' Immediately the karoub-tree, obeying the voice of Eliezer, arose out of the ground and planted itself a hundred cubits farther off. But the Rabbis shook their heads and answered, 'The karoub-tree proves nothing.' 'What,' cried Eliezer, 'you resist so great a miracle? Then let this rivulet flow backwards, and attest the truth of my doctrine.' Immediately the rivulet, obeying the command of Eliezer, flowed backwards towards its source. But again the Rabbis shook their heads and said, 'The rivulet proves nothing. We must understand before we can believe.' 'Will you believe me,' said Rabbi Eliezer, 'if the walls of this house wherein we sit should fall down?' And the walls, obeying him, began to fall, until Rabbi Joshua exclaimed, 'By what right do the walls interfere in our debates?' 'Then the walls stopped in their fall out of respect to Rabbi Joshua, but remained leaning out of respect for Rabbi Eliezer, and remain leaning until this day. But 
Eliezer, mad with rage, cried out: "Then in order to confound you, and since you compel me to it, let a voice from heaven be heard!' And immediately the Bath-Kol, or Voice from heaven, was heard at a great height in the air, and it said, "What are all the opinions of the Rabbis compared to the opinion of Rabbi Eliezer? When he has spoken, his opinion ought to prevail.' Hereupon Rabbi Joshua rose and said, 'It is written, "The law is not in heaven; it is in your mouth and in your heart." It is in your reason; for again it is written, "I have left you free to choose between life and death and good and evil." And it is in your conscience; for "if ye love the Lord and obey His voice within you, you will find happiness and truth." Wherefore then does Rabbi Eliezer bring in a karoub-tree, a rivulet, a wall, and a voice to settle questions of doctrine? And what is the only conclusion that can be drawn from such miracles, but that they who have expounded the laws of nature have not wholly understood them, and that we must now admit that in certain cases a tree can unroot itself, a rivulet flow backwards, walls obey instructions, and voices sound in the air? But what connection is there between these observations and the teaching of Rabbi Eliezer? No doubt these miracles were very extraordinary, and they have filled us with astonishment; but to amaze is not to argue, and it is argument, not phenomena, that we require. When, therefore, Rabbi Eliezer shall have proved to us that karoub-trees, rivulets, walls, and unknown voices afford us, by unusual manifestations, reasonings equal in value and weight to that reason which God has placed within us to guide our judgment, then alone will we make use of such testimonies and estimate them as Eliezer requires." "

To the same purport the famous commentator, Maimon- 
ides, says, "When thy senses affirm that which thy reason denies, reject the testimony of thy senses, and listen only to thy reason."

26. Having spoken of the Soul's functions, and of her relation to man, we come now to speak of her nature and history. Whether of the individual or of the universal, Soul is Substance, that which sub-stands all phenomena. This substance is original protoplasm; at once that which makes and that which becomes. The first manifestation of substance is in the interplanetary ether, called by Homer the "Middle Air," and known in the terminology of Occultism as the Astral Fluid. This, be it observed, is not soul, but that whereby soul is manifest, and in which it potentially subsists. Matter is the ultimate expression of substance, and represents that condition in which it is furthest removed from its original state, as the membranous capsule which forms the circumference of the physiologic cell represents the ultimate expression of the fluidic contents.

27. The Soul may be likened to the nucleus of the cell. The protoplasmic medium which is found within the capsular envelope and in which the nucleus floats, may be likened to the astral fluid, whether inter-planetary or inter-cellular. But the nucleus, the fluidic body surrounding it, and the exterior membrane, are all equally protoplasmic in nature, and the potentiality of one is in all; the difference actually observable among them being due only to difference of condition.

28. All the elements of the cell, however,-the nucleus included,-are material; whereas Matter itself is, whatever its kind, a mode of Substance, of which the nature is spiritual. But though Substance is, by its nature, Spirit, there is a sense in which Spirit is not Substance. This is 
the sense in which Spirit denotes will or energy, as distinguished from the Substance in which this inheres. Under impulsion of the Spirit as thus defined, Substance exchanges its static for a dynamic condition, repose for activity, becoming molecularised, and therefore materialised, in the process. It does not, however, cease to be Substance by becoming Matter ; but Matter ceases to be Matter by cessation of motion. Matter may thus be defined as Substance in a state of incessant, intense activity, which is the condition of every particle in the universe. From the microscopic molecule to the planet everything revolves, impelled by one force, and obeying one law.

29. The truth that Matter is Substance in its dynamic condition was well known to the hierophants of ancient India and Egypt, and finds expression in the Hebrew sacred books-which are Egyptian in origin-in the phrase,- - And on the seventh day, God rested from all His works, which God created and made."

This "resting"-which is not annihilation but reposeinvolves the return of Matter to its static condition of Substance. The idea presented is that of the cessation of active creative force, and the consequent return of phenomenal existence into essential being. This stage it is which constitutes the termination of the creative period, and the perfection of every creative work. It is at once the "rest which remains for the people of God;" the attainment of perfection by the individual, system, or race ; and the return of the universe into the bosom of God, by re-absorption into the original substance. The Buddhist terms it Nirvâna; and the period of which it is the termination is called by the Hindûs Kalpa, a word signifying Form. And they hold that the universe undergoes a succession of Kalpas, being at the end of each re-absorbed into Deity, Who then rests 
awhile prior to the next manifestation, reposing upon Sesha, the celestial "serpent," or living circle of Eternity, the symbol of essential Being, as opposed to ex-istence in its strict sense of manifested Being.

30. For, as will by and by be more fully shown, the substance of the soul, and therein of all things, and the substance of Deity, are one and the same; since there is but one Substance. And of this substance, the life is also called God, Who, as Living Substance, is at once Life and Substance, one and yet twain, or two in one. And that which is begotten of these two, and is, theologically, called the Son, and the Word, is necessarily the expression of both, and is, potentially, the Universe, for $\mathrm{He}$ creates it after His own Divine image by means of the Spirit $\mathrm{He}$ has received. Now the Divine Substance is, in its original condition, homogeneous. Every monad of it, therefore, possesses the potentialities of the whole. Of such a monad, in its original condition, every individual soul consists. And of the same substance, projected into lower conditions, the material universe consists. It undergoes, however, no radical change of nature through such projection; but its manifestation-on whatever plane occurring-is always as a Trinity in Unity, since that whereby substance becomes manifest, is the evolution of its Trinity. Thus-to reckon from without inwards, and below upwards-on the plane physical it is Force, universal Ether, and their offspring the material World. On the plane intellectual it is Life, Substance, and Formulation. On the plane spiritual-its original point of radiation-it is Will, Wisdom, and the Word. And on all planes whatsoever, it is, in some mode, Father, Mother, and Child. For "there are Three which bear record in 'heaven,' or the invisible, and these Three are One. And there are three which bear record on 'earth,' or 
the visible, and these three agree in one, being Spirit, Soul and Body." 2

31. The soul's entrance into Matter, and primal manifestation as an individual, occurs in the lowest modes of organic life, and is due to the convergence of the magnetic poles of the constituent molecules of some protoplasmic entity, an action due to the working of the Spirit in the Matter concerned. For all Matter, it must be remembered, has, and is, Spirit. The focussing of these poles gives rise to a circular magnetic current, of which the result is as an electric combustion, which is the vital spark, organic life, Soul. It is, however, no new creation in the ordinary sense of the term. For nothing can be either added to or withdrawn from the universe. It is but a new condition of the one substance already existing, a condition which constitutes a fresh act of individuation on the part of that substance. It has become, by self-generation, a soul or nucleus to the cell in which it has manifested itself. Such is the mode of operation of Substance, whether as manifested in the human soul or in the physiologic cell.

32. The doctrine of creation by development or evolution is a true doctrine, and is in no way inconsistent with the idea of divine operation; but the development is not of the original substance. Being infinite and eternal, that is perfect always. Development is of the manifestation of the qualities of that substance in the individual.

Development is intelligible only by the recognition of the inherent consciousness of the substance of existence. Of the qualities of that substance as manifested in the individual, Form is the expression. And it is because development is directed by conscious, experienced, and continually experiencing intelligence, which is ever seeking to eliminate 2 See App. No. III. 
the rudimentary and imperfect, that progression occurs in respect of Form. The highest product, man, is the result of the Spirit working intelligently within. But man attains his highest, and becomes perfect only through his own voluntary co-operation with the Spirit.

There is no mode of Matter in which the potentiality of personality, and therein of man, does not subsist. For every molecule is a mode of the universal consciousness. Without consciousness is no being. For consciousness is being.

33. The earliest manifestation of consciousness appears in the obedience paid to the laws of gravitation and chemical affinity, which constitute the basis of the later evolved organic laws of nutritive assimilation. And the perception, memory, and experience represented in man, are the accumulations of long ages of toil and thought, gradually advancing, through the development of the consciousness, from inorganic combinations upward to God. Such is the secret meaning of the old mystery-story which relates how Deucalion and Pyrrha, under the direction of Themis (Law), produced men and women from stones, and so peopled the renewed earth. These words of John the Baptist bear a similar signification:- "Verily I say unto you, that even of these stones God is able to raise up children unto Abraham." And by children of Abraham, are denoted that "spiritual Israel," the pure seekers after God, who finally attain and become one with the object of their quest.

34. As between Spirit and Matter, so between the organic and the inorganic there is no real barrier. Nature works in spirals, and works intelligently. In all that modern science has of truth, in respect of the doctrine of Evolution, it was anticipated thousands of years ago. But the scientists of old, using a faculty of the very existence of which those of the present day hear but to jeer at it, discerned in Soul 
the agent, and in Mind the efficient cause, of all progress. They perceived, as all now perceive who only allow themselves to think, that were Matter, as ordinarily regarded, all that is, and blind force its impelling agent, no explanation would be possible of the obviously intelligent adaptation, everywhere apparent, of means to ends; the strong set of the current of life in the direction of beauty and goodness; and the differentiation of uses, functions, and kinds, not only in cellular tissues, but even in crystalline inorganic elements. Why should Matter, if only what ordinarily it is supposed, - unconscious, aimless, purposeless, - differentiate, diversify, develop? This is the question the ancients asked themselves; and they were keen enough to see that in their very ability to ask it, lay the solution of the problem. For the question was prompted by Mind, and the presence of Mind in the product man, involves its presence in the substance whereof man consists, seeing that an extract cannot contain that which is not in its original source.

35. The reasonableness of this proposition is, however, at length beginning once again to be recognised even in the prevailing school, by some of the more intelligent of its members; one of these having recently declared it necessary, in order to account for the facts of existence, to credit Matter with a "little feeling." 3 This is an admission, which, carried to its legitimate issue, involves the recognition of the system now under exposition. For it involves the recognition of God and the Soul. Thus is modern science, painfully and against its will, working back towards the great doctrine taught long ages ago in the lodges of the Indian and Egyptian Mysteries, and verified by the spiritual experience of every epopt who lived the life prescribed as the condition of illumination.

${ }^{3}$ The late Professor Clifford. 
36. This is the doctrine known as that of the Transmigration of Souls. Of this doctrine the following concise description is taken from a translation dated $165^{\circ}$ of one of the so-called Hermetic books, which, emanating from Alexandria, and dating from pre-Christian or early Christian times, represent-at least in a measure-the esoteric doctrine of the Egyptian and other ancient religious systems. Of this body of writings only a few fragments survive. The passage cited is from book iv. of the work called The Divine Pymander, or Shepherd, of Hermes 'Trismegistus.

"From one Soul of the Universe are all those Souls which in all the World are tossed up and down as it were, and severally divided. Of these Souls there are many Changes, some into a more fortunate Estate, and some quite contrary. And they which are of Creeping Things are changed into those of Watery Things, and those of Things Living in the Water to those of Things living on the Land; and Airy ones into Men; and Human Souls that lay hold of Immortality are changed into (holy) Demons. And so they go on into the Sphere of the Gods. . . . And this is the most perfect Glory of the Soul. But the Soul entering into the Body of a Man, if it continue evil, shall neither taste of Immortality nor be Partaker of the Good; but being drawn back the same Way, it returneth into Creeping Things. And this is the Condemnation of an evil Soul."

37. The doctrine of the Progression and Migration of Souls, and of the power of man, while still in the body, to recover the recollections of his soul, constituted the foundation of all those ancient religions out of which Christianity had its birth; and was therefore universally communicated to all initiates of the sacred mysteries. And, indeed, one of the special objects of the curriculum of these institutions, was to enable the candidate to recover the memory of his 
previous incarnations, with a view to his total emancipation from the body. For the attainment of this power was regarded as a token that the final regeneration of the individual - when he would no'longer have need of the body and its lessons-was well-nigh accomplished. Thus the prime object of the ancient lodges which constituted the pre-Christian Churches, was the culture of the soul as the divine and permanent element of the individual.

38. Various eminent sages are said to have remembered some at least of their previous incarnations; and notably Krishna, Pythagoras, Plato, Apollonius, and the Buddha Gautama. This last-the "Messenger" who fulfilled for the mystics of the East the part which six hundred years later was, for the mystics of the West, fulfilled by Jesus-is stated to have recovered the recollection of five hundred and fifty of his own incarnations. And the chief end of his doctrine is to induce men so to live as to shorten the number and duration of their earth-lives. "He," say the Hindu Scriptures, "who in his lifetime recovers the memory of all that his soul has learnt, is already a god."

Socrates also is represented as distinctly asserting the doctrine of re-incarnation; and it was implied, if not expressed, in the system formulated by the superb modern thinker and scientist, Leibnitz.

39. Following the Rabbins, and especially the Pharisees, Josephus asserted the return of Souls into new bodies. Nor are recognitions of the doctrine wanting in the Old and New Testaments. Thus the writer of the Book of Wisdom says of himself: "Being good, I came into a body undefiled." The prophets Daniel and John are told by their inspiring angels that they shall stand again on the earth in the last days of the Dispensation. And of John it was also intimated by Jesus that he should tarry within reach of the 
earth-life, either for re-incarnation or metempsychosis when the appointed time should come. And of that great school which, apparently because it approached too near the truth to be safely tolerated by a materialising sacerdotalism, was denounced as the most dangerously heretical, - the school of the Gnostics, - the leader, Carpocrates, taught that the Founder of Christianity also was simply a person who, having a soul of great age and high degree of purity, had been enabled, through his mode of life, to recover the memory of its past. And Paul's description of him as a "Captain of Salvation made perfect through suffering," obviously implies a course of experience far in excess of any that is predicable of a single brief career.

To these instances must be added that of the question put to Jesus by his disciples respecting the blind man whom he had cured: "Did this. man sin, or his parents, that he was born blind?" For it shows either that the belief in transmigration was a popular one among the Jews, or that Jesus had inculcated it in his disciples. His refusal to satisfy their curiosity is readily intelligible on the supposition that he was unwilling to disclose the affairs of other souls.

40. The opening chapters of the Book of Genesis imply the like doctrine. For they present creation as occurring through a gradual evolution from the lowest types upwards, -from gaseous elemental combinations to the crowning manifestation of humanity in woman,- and thus indicate the animal as ministering to the human in a sense widely differing from that ordinarily supposed; for they represent the animal as the younger self of the man, namely, as man rudimentary. All this is involved in the fact that the term applied to the genesis of living things below man, signifies soul, 4 and is so translated when applied to man; whereas

- Heb., Nophesh ; i.e., the lowest mode of soul. 
when applied to beasts it is rendered "living creature." Thus, had the Bible been accurately translated, the doctrine that all creatures whatsoever represent incarnations, though in different conditions, of one and the same universal soul, would not now need to be re-declared, or when re-declared, would not be received with repugnance. That it does produce such a feeling, is a sign how far man has receded from a level once attained, at least in respect of his affectional nature. For the doctrine of a universal soul is the doctrine of love, in that it implies the recognition of the larger self. It represents, moreover, Humanity as the one universal creation of which all living things are but different steps either of development or of degradation, progression or retrogression, ascent or descent; that which determines the present condition and ultimate destiny of each individual entity, being its own will and affections. Animals appeared first on earth, not, as is vainly supposed, to minister to man's physical wants, but as an essential preliminary to humanity itself. On no other hypothesis is their existence intelligible for the long ages which elapsed before the appearance of man.

4I. Thus, not only is the doctrine respectable for its antiquity, universality, and the quality and character of those who, on the strength of their own experience, have borne testimony to it ; it is indispensable to any system of thought which postulates Justice as an essential element of Being. For it, and it alone of all methods ever suggested, solves the problem of the universe by resolving the otherwise insuperable difficulties which confront us in regard to the inequalities of earthly circumstance and relation.

The importance attached to it by the Egyptians is shown by the fact that they chose for their chief religious symbol an embodiment of it. For in representing the owest as 
linked to the highest, - the loins of the creature of prey to the head and breast of the Woman,- the Sphinx denoted at once the unity, and the method of development, under individuation, of the soul of the universal humanity.

\section{PART II.}

42. We will now define more precisely the nature of the system we seek to restore, and its relation towards that so long in possession in the West. Although neither Christian nor Catholic in the accepted sense of these terms, it claims to be both Christian and Catholic in their original and true sense, and to be itself the lawful heir, whose inheritance has been usurped by a presentment altogether corrupt, false, superstitious, idolatrous.

According to the system recovered, the Christ Jesus, Redeemer, and Saviour, while equally its beginning, middle, and end, is not a mere historical personage, but, above and beyond this, a Spiritual Ideal and an Eternal Verity. Recognising fully that which Jesus was and did, it sets forth salvation as depending, not on what any man has said or done, but on what God perpetually reveals. For, according to it, Religion is not a thing of the past, or of any one age, but is an ever-present, ever-occurring actuality; for every man one and the same; a process complete in itself for each man; and for him subsisting irrespective of any other man whatsoever. It thus recognises as the actors in the momentous drama of the soul two persons only, the individual himself and God. And whereas in it alone is to be found a complete and reasonable exposition of the parts assigned to both in the work of salvation, all competing systems must be regarded as but an aspiration towards or a degeneration from it, and as true only in so far as they accord with it. 
43. And here it may be remarked, that the doctrine of religion as a present reality, needing no historic basis, is one which in this age ought to find special welcome. For, what now is the condition of men's minds in respect to the historical element of the existing religion? None but those who through lack of education stand necessarily upon the old ways, have any reliance upon it. Critical analysis-that function of the mind which, in its nature destructive, is, nevertheless, really harmful only to that which, in being untrue, has not in itself the element of perpetuity-has laid an unsparing axe to the forest of ancient tradition. The science of Biblical exegesis has made it obvious to every percipient mind that sacred books, so far from being infallible records of actual events, abound with inaccuracies, contradictions, and interpolations; that sacred persons, if they existed at all, had histories differing widely from those narrated of them; that sacred events could not have occurred in the manner stated; and that sacred doctrines are, for the most part, either intrinsically absurd, or common to systems yet more ancient, whose claims to sanctity are denied.

44. Thus, to take the leading items of Christian belief, - the whole story of the Incarnation, the expectation of the Messiah, the announcement by the angel, the conception by the Virgin, the birth at midnight in a cave, the name of the immaculate mother, the appearance to shepherds of the celestial host, the visit of the Magi, the flight from the persecuting Herod, the slaughter of the innocents, the finding of the divine boy in the temple, the baptism, the fasting and trial in the wilderness, the conversion of the water into wine, and other like marvels, the triumphal entry into the holy city, the passion, the crucifixion, the resurrection, and the ascension, and much of the teach- 
ing ascribed to the Saviour,-all these are variously attributed also to Osiris, Mithras, Iacchos, Zoroaster, Krishna, Buddha, and others, at dates long antecedent to the Christian era. And monuments and sculptures still exist, showing that the entire story of the Divine Man of the Gospels was, long before Moses, taught to communicants and celebrated in sacraments in numberless colleges of sacred mysteries. ${ }^{5}$

45. The Fathers of the Church-who were well aware of these facts-dealt with them variously according to the tone and resources of their individual minds. Many of the most notable, including St. Augustine, saw the truth in its proper light; but the explanation accepted was, that the Devil, foreknowing the counsel and intention of God, had maliciously forestalled the career of the true Messiah by false semblances, causing it to be enacted in anticipation by a number of spurious messiahs, so that when the world's true redeemer should appear, he might be lost, as it were, in the crowd of his predecessors, and shorn of all particular glory.

46. And what, it may be asked, of the personage just mentioned, who plays so enormous a part in the orthodox presentment? He, too, is a perversion of a truth, the real meaning of which will by and by be exhibited. It is suffcient to remark here, that, in being founded-as by the current corrupt orthodoxy - on the conception of a personal and, virtually, a divine principle of evil, Christianity is made to rest upon an hypothesis altogether monstrous and impossible.

47. There is neither space nor need to particularise the

"For a comparative list of some "pre-Christian data" which were "Christianised in the Canonical Gospels and the Book of Revelation," see Ancient Egypt, by Gerald Massey (1907), vol. ii., pp. 907-914. 
strictures to which the Bible, throughout, is fairly open alike on grounds historical, moral, and scientific; or to speak of the many ecclesiastical Councils which, from century to century, have dealt with its component books, variously affirming or denying their canonicity; or to point out the innumerable contradictions and inconsistencies, of doctrine and of narrative, with which it abounds. These things, already familiar to many, are readily verifiable by all. This only must be insisted on; - to be a student of religion, to be a theologian in the true sense, it is necessary to have knowledge, not of one religion only, but of all religions, not of one sacred book only, but of all sacred books; and to deal with all as with the one, and with the one as with all; to handle the Vedas, the Bhagavad-Gitâ, the Lalita-Vistara, the Zend-Avesta, and the Kabbala with the same reverence as the Old and New Testaments; and to apply to these the same critical touch-stone as to those. It is truth alone which is valuable, and this fears nothing. The crucible does not hurt the gold. The dross alone falls away under the test; and of the dross we are surely well rid.

48. And when all this has been done; when the mind, purified from prejudice and disciplined by experience, has become an instrument of knowledge competent for the discernment of truth, what, it will be asked, remains to man of his faith and hope, his God and his soul? We know the reply of the Materialist. $\mathrm{He}$, as has been wittily said, throws away the child with the water in which it has been washed. Because he finds impurity obstructing the truth, he rejects the truth together with the impurity. That which remains is the real, ever-living religion; a Divine and operating Word, and not a testament of the dead; a God and a Soul who, as Parent and Offspring, are able to 
come into direct and palpable relations with each other. And the Creation, the Fall, the Redemption, and the Ascension-rescued from the tomb of the past-become living and eternal verities, enacted by every child of God in his own soul; and Inspiration once more lifts its voice and is heard among us as truly as of old.

49. For those, then, who, being indeed of Christ, as well as calied by his name, know by personal experience that "the kingdom of heaven is within," there is no cause for anxiety as to the issue of any investigation, critical, scientific, or historical, how keen and unsparing soever. For they know that Religion-which is the Science of Life Eternalappeals, not to the bodily senses, but to the soul, since no mere physical phenomena can have any relation to spiritual needs. They know, too, that in representing absolute, eternal verities, religious ideas are beyond the reach of any power of earth to erase or destroy them. But they who, on the contrary, have staked their all of faith in God and hope in heaven upon the special events of a particular period and place, have indeed ground for dismay and despair when they behold in the sculptured remains of other places and remoter times, the effigies of the like events, - the crucifixion of Mithras, the infant Horus or Krishna in the arms of an immaculate mother, the resurrection of Osiris, and the ascension of Heracles. For they see in these, the invalidation, or at least the perplexing multiplication, of events which, on their hypothesis, ought to have happened but once in the world's-nay, in the universe's-whole history, and on the correct reporting of which their eternal welfare depends. The actual value of these facts will appear as we proceed. They are cited here in demonstration of the fallacy involved in the conception of religion as a thing dependent on history. Rightly interpreted, they 
will show that the Soul has no relation to phenomena, and that "the kingdom of Christ is not of this world."

50. The Gospels bear evidence of being compiled or adapted in great measure from older Oriental Scriptures. But whether or not the events related happened only in part or not at all ; whether they were put into their present form by Alexandrian Epopts some hundred years after the date assigned in them to the events they record; or whether their central figure, being himself an Initiate and Adept in the religious science of Egypt and India, actually rehearsed in his own person the greater part of the sacred mysteries, -is, happily, but of secondary importance. And even were it otherwise, it is obvious that the further we get away from the period of the events relied on, and the more years multiply upon us, thrusting that past into still remoter times and ever deepening shades of antiquity, the more difficult must the task of verification become, and the weaker the influences thence exerted upon man's moral and intellectual nature. Alas for the hopes of the generations yet to be born, if an historical Christianity be indeed essential to salvation! Nor can we be blind to the injustice and cruelty of making salvation dependent upon belief in occurrences concerning which only a learned few can at any time be in a position to judge whether or not they ever took place; and these, moreover, occurrences of a nature to be $a$ priori incredible save to an elect few. Assuredly, if any demonstration be needed of the necessary unsoundness of a system which rests upon history, it is to be found in the present condition of Christianity. Declining to entrust its doctrine to Reason, the Church has taken its stand upon historical evidence, only to find this give way under it; and it is now without any basis save that of Custom. The time has come in which Christians are Christians, only 
because they are accustomed to be Christians. Habit has superseded conviction.

5I. Very different is the relation between the human mind and the system under exposition. Appealing to the understanding, and condemning as superstition the faith which is not also knowledge, this system meets unshaken the tests alike of time and of reason; and, so far from looking coldly on science, hails it as an indispensable ally, stipulating only that it be science, and not that which is "falsely so called." Hoping everything and fearing nothing from the light of reason, it welcomes the searching ray into every recess, and greets with eager hands the philosopher, the historian, the critic, the philologist, the mathematician, the classic, the physicist, and the occultist. For its appeal is to intelligence as developed by knowledge, in the absolute assurance that where these exist in the greatest plenitude, there it will gain the fullest recognition.

52. And the intelligence appealed to is not of the head only, but is also of the heart ; of the moral conscience as well as of the intellect. Insisting upon the essential unity of all being, it admits of no antagonism between the human and the Divine. But holding that the human is the Divine, and that that which is not Divine is sub-human, it seeks, by the demonstration of the perfection of God, to enable man to perfect himself after the image of God. And it claims, moreover, to be the one philosophy wherein that image finds intelligent exposition, and whereby it obtains practical recognition. To the question why, being in all respects so admirable, it has become lost or perverted, the answer involves the history of man's original Fall, and will in due course appear.

53. There are two or three classes of objectors, to whom 
reply will now be made in anticipation. Of these classes one is that which, under the influence of the prevailing Materialism, holds, that so far from the phrase just employed, "Image of God," having any basis in reality, modern science has practically demonstrated the nonexistence of God. If the following reply to this class involves a reference to regions of being as yet unrecognised in their own science, it is not upon us that the responsibility for the limitation rests. We speak of that which we know, having learned it by experience.

$54 .{ }^{6} \mathrm{~A}$ true Idea is the reflect of a true Substance. It is because religious ideas are true ideas that they are common to all ages and peoples; the differences being of expression merely, and due to the variation of density and character of the magnetic atmosphere through which the image passes. The fact that every nation in every age has conceived, in some shape, of the Gods, constitutes of itself a proof that the Gods really are. For Nothing projects no image upon the magnetic light; and where an image is universally perceived, there is certainly an object which projects it. An Idea, inborn, ineradicable, constant, which sophism, ridicule, or false science has power to break only, but not to dispel:- -an image which, however disturbed, invariably returns on itself and reforms as does the image of the sky or the stars in a lake, however the reflecting water may be momentarily shaken by a stone or a passing vessel:- - such an image as this is necessarily the reflection of a real and true thing, and no illusion begotten of the water itself.

In the same manner the constant Idea of the Gods, persistent in all minds in all ages, is a true image; for it

6 This paragraph was taken down by Edward Maitland as spoken by Anna Kingsford under Illumination (Life of $A$. $K$., vol. ii., p. 32). 
is verily, and in no metaphoric sense, the projection upon the human perception of the Eidola of the Divine persons. The Eidolon is the reflection of a true object in the magnetic atmosphere; and the magnetic atmosphere is a transparent medium, through which the soul receives sensations. For sensation is the only means of knowledge, whether for the body or for the reason. The body perceives by means of the five avenues of touch. The soul perceives in like manner by the same sense, but of a finer sort and put into action by subtler agents. The soul can know nothing not perceptible; and nothing.not perceptible is real. For that which is not can give no image. Only that which is can be reflected.

55. To the other classes of objectors, who are chiefly of the religious and orthodox order, the following considerations are addressed.

$a$. The apparently new is not necessarily the rcally new ; but may be a recovery-providential, timely, and precious - of the old and original which has been forgotten, perverted, or suppressed.

b. So far from it being incumbent on Christians to accept the established in religion as necessarily the true and the right, the condemnation by the later Hebrew prophets of the established form of Judaism, as no longer in their time representing the religion divinely given through Moses, imposes on Christians the duty of exercising, at the least, hesitation before accepting the established form of Christianity as faithfully representing the religion divinely given through Jesus. Christendom has been exposed for a far longer period than was Israel, to influences identical with those which caused the deterioration denounced by the prophets, namely, the abandonment of religion, without prophetic guidance or correction, to a control exclusively 
sacerdotal, and therein to Tradition uninterpreted by Intuition. And not only so, but on the first formal definition and establishment of Christianity under Constantine,himself an ardent votary of a sun-worship become grossly materialistic, - the dominant conception was far more in accordance with the principles of sacerdotalism than with those of its Founder. There remains, also, the strong $a$ priori improbability that a system identical with that which, in consequence of the efforts of Jesus to purify it, became his destroyer, -a system exclusively sacerdotal and traditional,- should, even though calling itself Christian, prove a trusty guardian and faithful expositor of his doctrine.

c. The belief that Christianity was indeed divinely intended and adapted to effect the redemption of the world from engrossment by the elements merely material of existence, to the recognition and appreciation of its spiritual and true substance; and the fact that thus far Christianity has signally failed to accomplish that object,-make it in the highest degree obligatory on Christians, both to seek diligently the cause of such failure, and to seek it elsewhere than in an original defect of the religion itself.

$d$. According to numerous indications-including the express declarations of Jesus himself - much that is essential to the proper comprehension and practical application of Christian doctrine, was reserved for future disclosure. History has yet to record the full manifestation of that "Spirit of Truth," who was to testify of Jesus, and lead his followers into all truth. And the world has still to see the Christ-ideal so "lifted up" and exhibited as, by force of its perfection as a system of life and thought, irresistibly to "draw all men" to it.

$e$. In point alike of character and of time, the present period coincides with that indicated in numerous pro- 
phecies, as appointed for the close of the old and the commencement of a new era. This is necessarily an event which can come about only through some radical change in the course of the world's thought. For, in being, however unconsciously to itself, a product of Mind, the world always follows its thought. The world has now followed its thought in the direction of Matter and blind force, until, for the first time in man's history, its recognised intellect has, almost with one consent, pronounced decidedly against the idea of God. This, therefore, is no other than that "time of the end" whereof the token should be the exaltation of Matter instead of Spirit, and the obtrusion into the "holy place" of God and the soul, of the "abomination that maketh desolate," to the utter extinction of the world's spiritual life and of the idea of a divine Humanity. Now is "that wicked one" and "man of sin"-that is, humanity deliberately self-made in the image of the Not-God-definitively revealed; and the gospel of Love is confessedly replaced by the gospel of Force. $^{7}$ Of the prophecies, moreover, which referred to the period in question, it was declared that the words should be "closed up and sealed till the time of the end." The very discovery of the true interpretation of the mystical Scriptures, would therefore constitute an indication that the "end is at hand."

$f$. If it be, indeed, that man is not to "go down quick into the pit" that he has dug for himself, the emergency is one with which religion alone can grapple. But, so far from the religion already in the world being competent for the task, it has, by reason of its own degeneracy, ministered

7 It is not a little remarkable, that the foremost symbol of this new gospel should have for name the Greek term for force; dynamile being simply sivvauis. 
to the evil. Wherefore only by a religion which is not that now in vogue, can man be saved. Time alone, of course, can determine if, or by what means, the needed redemption will be wrought. Enough has been said to show that, from the religious point of view, there is ample reason in favour of according a serious hearing even to doctrines and claims so strange and unfamiliar to most persons as those herein advanced.

56. Finally, to close this Introductory Lecture, and to reassure those who, desirous to know more, are yet apprehensive of finding themselves in the issue, like the patriarch of old, robbed of their gods, we add this final reflection:The end in view is not denial, but interpretation; not destruction, but reconstruction, and this with the very materials hitherto in use. No names, personages, or doctrines now regarded as divine will be rejected or defamed. And even though the indubitable fact be recognised, that the "one name given under heaven whereby men can be saved" has been shared by many, that name will still be the name of salvation, and the symbol of its triumph will still be the cross of Jesus, even though borne before him by, or in the name of, an Osiris, a Mithras, a Krishna, a Dionysos, or a Buddha, or any others who, overcoming by love the limita. tions of Matter, have been faithful to the death mystically called the death of the cross, and, attaining thereby the crown of eternal life for themselves, have shown to men the way of salvation.

Instead, then, of indulging apprehension on the score indicated, let heed rather be given to the true moral of the story of all the Christs, how many soever they be, by whom is enacted in its fulness, while yet in the body, the divine drama of the soul. For, with Christ, all may, in their degree, be redeemers alike of themselves and of others ; and 
with him, to redeem, they must themselves first love and suffer and die. For, as said the German mystic, Scheffler, two centuries ago, -

"Though Christ a thousand times in Bethlehem be born, But not within thyself, thy soul will be forlorn:

The cross of Golgotha thou lookest to in vain, Unless within thyself it be set up again." 


\section{LECTURE THE SECOND.1}

THE SOUL; AND THE SUBSTANCE OF EXISTENCE.

\section{PART I.}

I. OUR theme is that which is at once the supreme subject and object of culture, and the necessary basis of all real religion and science. For it is the substance of existence, the Soul, universal and individual, of humanity. Only when we know the nature of this, can we know what we ourselves are, and what we have it in us to become. For our potentialities necessarily depend upon the substance whereof we are made.

2. This is not Matter. Wherefore a science which, in being restricted to the cognition of phenomena, is a materialistic science, cannot help us to an understanding of ourselves. But, on the contrary, to such understanding such science is, in its issues, the greatest enemy. Matter is not God; and in order to understand ourselves, it is necessary to understand God. God is the Substance of existence. Be that substance what it may, it still is God; and of God no other definition is possible or desirable, but all conditions are satisfied by it. To know God, then, is to know this substance ; and to know this, is to know ourselves, and only by knowing this can we know ourselves.

1 This lecture was written by Edward Maitland mainly from Illuminations received by Anna Kingsford: and was delivered by him on Monday the 23rd May, I881 (Life of $A$. $K$., vol. ii., pp. 16, 17, 32). 
3. Such, and no other or less, was the meaning of the famous mystic utterance inscribed on the temple porch at Delphi,-Know thyself,-a sentence which, notwithstanding its brevity, comprehends all wisdom. An attempt, it is true, has been made to improve upon it in the saying,Ignore thyself, and learn to know thy God. But that which is intended in the latter, is, albeit unsuspected by its framer, comprised in the former. For, as is known to the Mystic -or student of Substance-such is the constitution of the universe, that man cannot know himself without knowing God, and cannot know God without knowing himself. And as, moreover, only through the knowledge of the one can the knowledge of the other be attained, so the knowledge of the one implies and involves that of the other. For, as the Mystic knows, there is but one substance alike of man and of God.

4. This substance, we repeat, is not Matter; and a science which recognises Matter only, so far from ministering towards the desired comprehension of ourselves, is the deadly foe of such comprehension. For, as Matter is, in the sense already described, the antithesis of Spirit, so is Materialism the antithesis of the system under exposition, namely, of Mysticism, or, as we propose to call it, Spiritualism. And here it must be understood that we use this latter term, not in its modern debased and limited sense, but in its ancient proper purity and plenitude, that wherein it signifies the science, not of spirits merely, but of Spirit, that is, of God, and therein of all Being. Thus adopting and rehabilitating the term Spiritualism, we define as follows:-first, the system we have recovered and seek to establish; and, next, the system we condemn and seek to destroy.

5. Dealing with both substance and phenomenon, Spirit 
and Matter, the eternal and the temporal, the universal and the individual ; constituting respecting existence a complete system of positive doctrine beyond which neither mind nor heart can aspire ; providing a rule of knowledge, of understanding, of faith, and of conduct ; derived from God's own Self; transmitted and declared by the loftiest intelligences in the worlds human and celestial; and in every respect confirmed by the reason, the intuition, and the experience of the earth's representative men, its sages, saints, seers, prophets, redeemers, and Christs, and by none in any respect confuted;-the system comprised under the term Spiritualism is not only at once a science, a philosophy, a morality, and a religion, but is the science, the philosophy, the morality, and the religion of which all others are, either by aspiration or by degeneration, limitations merely. And according to the degree of its acceptance by man, it ministers to his perfection and satisfaction here and hereafter.

6. But its antithesis:-Springing from the bottomless pit of man's lower nature; having for its criterion, not the conclusions of the mind or the experiences of the soul, but only the sensations of the body; and being, therefore, not a science, nor a philosophy, nor a morality, nor a religion, but the opposite of each and all of these,-the system comprised under the term Materialism is not a limitation of Spiritualism but is the negation of it, and is to it what darkness is to light, nonentity to existence, the "devil" to God. And in proportion to the degree of its acceptance by man, it ministers to his deterioration and destruction here and hereafter.

7. Between the two extremes thus presented, having liberty to choose, and power to determine his own destination, man, according to mystical doctrine, is placed, in pursuance of the Divine Idea, of which creation is the mani- 
festation. And whereas, in implying the culture of the substantial, Spiritualism, as we use the term, represents Reality; and in implying the culture of the phenomenal only, Materialism represents Illusion, the choice between them is the choice between the Perfection and the Negation of Being.

8. But whatever the quarrel of the Spiritualist with Materialism for its exclusive recognition of Matter, and consequent idolatry of form and appearance, with Matter itself he has no quarrel. For, although, by reason of its limitations, the cause of evil, Matter is not in itself evil. On the contrary, it comes forth from God, and consists of that whereof God's Self consists, namely, Spirit. It is Spirit, by the force of the Divine will subjected to conditions and limitations, and made exteriorly cognisable.

9. Matter is thus a manifestation of that which in its original condition is unmanifest, namely, Spirit. And Spirit does not become evil by becoming manifest. Evil is the result of the limitation of Spirit by Matter. For Spirit is God, and God is good. Wherefore, in being the limitation of God, Matter is the limitation of good. Such limitation is essential to creation. For without a projection of Divine Substance, that is, of God's Self, into conditions and limitations, - of Being, which is absolute, into Existence, which is relative,-God would remain inoperative, solitary, unmanifest, and consequently unknown, unhonoured, and unloved, with all God's power and goodness potential merely and unexercised. For aught else to exist than God, there must be that which is, by limitation, inferior to God. And for this to exist in plenitude corresponding to God's infinitude, it must involve the idea of the opposite and negation of God. This is to say:-Creation, to be worthy of God, must involve the idea of a No-God. God's absolute plenitude in 
respect of all the qualities and properties which constitute Being, must be contrasted by that utter deprivation of all such properties and qualities, which constitutes Not-being. Between no narrower extremes can a Divine creation be contained. By no lesser contrast can God be fully manifested. The darkness of God's shadow must correspond in intensity with the brightness of God's light. And only through the full knowledge of the one, can the other be duly apprehended and appreciated. $\mathrm{He}$ only can thoroughly appreciate good who has ample knowledge of evil. It is a profound truth, that "the greater the sinner, the greater the saint." That exquisite epitome of the Soul's history, the parable of the Prodigal Son, is based upon the same text. Only they who have gone out from God, returning, know God. At once consequence and cause of the going out from God, Matter is an indispensable minister to Creation, without which and its limitations Creation were not.

Io. But mere Creation does not represent the totality of the Divine purpose. And a creation restricted to the actualities of Matter would be the reverse of a boon to itself or a credit to God. For by a creation thus limited, Deity would have shown Itself to be that only which the Materialist imagines It, namely, Force. Whereas "God is Love." And Love is that, not which merely creates and after brief caress repudiates and discards; but which sustains, redeems, perfects, and perpetuates. And to these ends Matter ministers indispensably, and therein contributes towards that second creation which is the supplement and complement of the first. This second creation is called Redemption, and in it the Creator finds His recognition and glorification, and man his perfection and perpetuation. For Redemption is the full compensation, both to God and to the universe, for 
all that is undergone and suffered by and through Creation. And it is brought about by the return from Matter of Spirit, to its original condition of purity, but individuated and enriched by the results of all that has been gained through the processes to which it has been subjected;results which, but for Matter, could not have been. Matter is thus indispensable to the processes both of creation and of perfection. For that through which we are made perfect is experience, or suffering; and we are only really alive and exist in so far as we have felt. Now, of this divine and indispensable ministry of experience, Matter is the agent.

11. Such being for the Spiritualist, who also is Mystic and not Phenomenalist merely, the origin, nature, and final cause of Matter, he has with it no ground of quarrel. But recognising it as intended not to conceal but to reveal God, and to minister to man's creation in the image of God, he regards the material universe as a divine revelation, and seeks, by humble, reverent, and loving analysis of it, to learn both it and God, and thus to make it minister to his own perfection. "Imitation," it has been said, and truly, "is the sincerest flattery." And man best honours God when he seeks to be like God. In this pursuit it is that, following his intuition of Spirit, he ascends from the exterior sphere of Matter and appearance-that sphere which, as the outermost of man's system, constitutes the border-land between him and negation, and is therefore next neighbour to that which, mystically, is called the devil - to the interior sphere of Spirit and Reality, where God subsists in His plenitude. And so, from Nature's Seeming he attains to the cognition at once of God's and his own Being.

12. The system by the knowledge and observance of 
which these supreme ends are attained, and which is now for the first time in the world's history openly disclosed, has constituted the hidden basis of all the world's divine revelations and religions. For from the beginning there has been one divine Revelation, constantly re-revealed in whole or in part, and representing the actual eternal nature of existence; and this in such measure as to enable those who receive it to make of their own existence the highest and best that can possibly be imagined or desired. Known by various names, delivered at various places and periods, and finding expression under various symbols, this revelation has constituted a Gospel of Salvation for all who have accepted it, enabling them to escape the limitations of Matter and return to the condition of pure Spirit, and therein to attain immunity, not merely, as is ordinarily desired, from the consequences of sin, but from the liability to $\sin$. And, as history shows, wherever it has succeeded in obtaining full manifestation, Materialism, with all its foul brood, has fled discomfited, like Python, the mighty Serpent of Darkness, before the darts of Phoibos, to make its dwelling in the caverns and secret places of earth.

PART II.

13. Coming, then, to the proper subject of this Lecture, we will now treat of the Soul, universal and individual, commencing with the latter.

The soul, or permanent element in man, is first engendered in the lowest forms of organic life, from which it works upwards, through plants and animals, to man. Its earliest manifestation is in the ethereal or fluidic material called the astral body; and it is not something added to that body, but is generated in it by the polarisation of the elements. Once generated, it enters into and passes 
through many bodies, and continues to do so until finally perfected or finally dissipated and lost. The process of its generation is gradual. The magnetic forces of innumerable elements are directed and focused to one centre; and streams of electric power pass along all their convergent poles to that centre, until they create there a fire, a kind of crystallisation of magnetic force. This is the Soul, the sacred fire of the hearth, called by the Greeks Hestia, or Vesta, which must be kept burning continually. The astral and fluidic body, its immediate matrix, - called also the perisoul,--and the material or fixed body put forth by this, may fall away and disappear; but the soul, once begotten and made an individual, is immortal, until its own perverse will extinguishes it. For the fire of the soul must be kept alive by the Divine Breath, if it is to endure for ever. It must converge, not diverge. If it diverge, it will be dissipated. The end of progress is unity; the end of degradation is division. The soul, therefore, which ascends, tends more and more to union with and absorption into the Divine.

14. The clearest understanding may be obtained of the soul by defining it as the Divine Idea. Before anything can exist outwardly and materially, the idea of it must subsist in the Divine Mind. The soul, therefore, may be understood to be divine and everlasting in its nature. But it does not act directly upon Matter. It is put forth by the Divine Mind ; but the body is put forth by the astral, or "fiery," body. As Spirit, on the celestial plane, is the parent of the soul, so Fire, on the material plane, begets the body. The plane on which the celestials and creatures touch each other, is the astral plane.

15. The soul, being in its nature eternal, passes from one form to another until, in its highest stage, it polarises suf- 
ficiently to receive the spirit. It is in all organised things. Nothing of an organic nature exists without a soul. It is the individual, and perishes finally if uninformed of the spirit.

16. This becomes readily intelligible if we conceive of God as of a vast spiritual body constituted of many individual elements, all having but one will and therefore being one. This condition of oneness with the Divine Will and Being, constitutes what, in Hinda mysticism, is called the celestial Nirvâna. But though becoming pure Spirit, or God, the individual retains his individuality. So that, instead of all being finally merged in the One, the One becomes Many. Thus does God become millions. "God is multitudes, and nations, and kingdoms, and tongues; and the sound of God is as the sound of many waters."

17. The Celestial Substance is continually individualising Itself, that It may build Itself up into One perfect Individual. Thus is the Circle of Life accomplished, and thus its ends meet the one with the other. But the degraded soul, on the other hand, must be conceived of as dividing more and more, until, at length, it is scattered into many, and ceases to be as an individual, becoming, as it were, split, and broken up, and dispersed into many pieces. This is the Nirvâna of annihilation.'

18. The Planet must not be looked upon as something apart from its offspring. It, also, is a Person, fourfold in nature, and having four orders of offspring, of which orders man alone comprises the whole. Of its offspring some lie in the astral region only, and are but twofold; some in the watery region, and are threefold; and some in the human region, who are fourfold. The metallic and magnetic envelopes of the planet are its body and perisoul. The ${ }^{2}$ See C.W.S., part ii., No. iv., p. 22 I. 
organic region comprises its soul; and the human region its spirit, or divine part. When it was but metallic it had no individualised soul. When it was but organic it had no divine spirit. But when man was made in the image of God, then was its spirit breathed into its soul. In the metallic region soul is diffused and unpolarised; and the metals, therefore, are not individual; and not being individual, their transmutation does not involve transmigration. But the plants and animals are individual, and their essential element transmigrates and progresses. And man has also a divine spirit; and so long as he is man-that is, truly human-he cannot redescend into the body of an animal or any creature in the sphere beneath him, since that would be an indignity to the spirit. But if he lose his spirit, and become again animal, he may descend, and -disintegrating - become altogether gross and horrible. This is the end of persistently evil men. For God is not the God of creeping things ; but Impurity-personified by the Hebrews as Baalzebub-is their god. And there were none of these in the Age of Gold, neither shall there be any when the earth is fully purged. Man's own wickedness is the creator of his evil beasts. ${ }^{3}$

19. The soul is not astral fluid, but is manifest by astral fluid. For the soul itself is, like the idea, invisible and intangible. This may be best seen by following out the genesis of any particular action. For instance, the stroke of the pen on paper is the phenomenon, that is, the outer body. 'The action which produces the stroke, is the astral body; and, though physical, it is not a thing, but a transition or medium between the result and its cause, - between, that is, the stroke and the idea. The idea, manifested in the act, is not physical, but mental, and is the soul of the ' Comp. Bhagavad-Gina, I. xvi. 
act. But even this is not the first cause. For the idea is put forth by the will, and this is the spirit. Thus, we will an idea, as God wills the Macrocosm. The potential body, its immediate result, is the astral body ; and the phenomenal body, or ultimate form, is the effect of motion and heat. If we could arrest motion, we should have as the result, fire. But fire itself also is material, since, like the earth or body, it is visible to the outer sense. It has, however, many degrees of subtlety. The astral, or odic, substance, therefore, is not the soul itself, but is the medium or manifestor of the soul, as the act is of the idea.

20. To pursue this explanation a little further. The act is a condition of the idea, in the same way as fire, or incandescence, is the condition of any given object. Fire is, then, the representative of that transitional medium termed the Astral body; as Water-the result of the combined interaction of Wisdom the Mother, or Oxygen, and Justice the Father, or Hydrogen-is of the Soul. Air, which is produced by the mixture-not combination-of Wisdom and Force (Azoth), represents the Spirit-One in operation, but ever Twain in constitution. Earth is not, properly speaking, an element at all. She is the result of the Water and the Air, fused and crystallised by the action of the Fire; and her rocks and strata are either aqueous or igneous. Fire, the real maker of the body, is, as we have seen, a mode and condition, and not a true element. The only real, true, and permanent elements, therefore, are Air and Water, which are respectively, as Spirit and Soul, Will and Idea, Father and Mother. And out of these are made all the elements of earth by the aid of the condition of Matter, which is, interchangeably, Heat and Motion. Wisdom, Justice, and Force, or Oxygen, Hydrogen, and Azoth, are the three out of which the two true elements are produced. 
21. Material body, astral fluid or sideral body, soul, and spirit, all these are one in their essence. And the first three are differentialities of polarisation. The fourth is God's Self. When the Gods-the Elohim or Powers of the Hebrews-put forth the world, they put forth substance with its three potentialities, but all in the condition of "odic" light. This substantial light is called sometimes the sideral or astral body, sometimes the perisoul, and this because it is both. It is that which makes, and that which becomes. It is fire, or the anima bruta (as distinguished from the Divine), out of and by means of which body and soul are generated. It is the fiery manifestation of the soul, the magnetic factor of the body. It is space, it is substance, it is foundation; so that from it proceed the gases and the minerals, which are unindividuated, and from it also the organic world which is individuated. But man it could not make; for man is fourfold, and of the divine ether, the province assigned by the Greeks to Zeus, the father of Gods and men.

22. The outer envelope of the macrocosm and the microcosm alike, the Earth or body, is thus in reality not elemental at all, but is a compound of the other three elements. Its fertility is due to the water, and its transmutory or chemical power to the fire. The water corresponds to the soul,-the "best principle" of Pindar, - while fire is to the body what spirit is to the soul. As the soul is without divinity and life until vivified by the spirit, so the bodyearth or Matter-is without physical life in the absence of fire. No Matter is really dead Matter, for the fire element is in all Matter. But Matter would be dead, would cease, that is, to exist as Matter, if motion were suspended, which is, if there were no fire. For, as wherever there is motion there is heat, and consequently fire, and motion is the 
condition of Matter; so without fire would be no Matter. In other words, Matter is a mode of life.

\section{Part III.}

23. We come now to the history and progress of the soul. Souls, we have said, work upwards from plants and animals to man. In man they attain their perfection and the power to dispense altogether with material bodies. Their ability to do this is the cause and consequence of their perfection. And it is the attainment of this that is the object of the culture of the soul-the object, that is, of religion. Spirit alone is good, is God. Matter is that whereby spirit is limited, and is, therein, the cause of evil ; for evil is the limitation of good. Wherefore to escape from Matter and its limitations, and return to the condition of spirit, is to be superior to the liability to evil.

24. Formerly the way of "escape for human souls was more open than now, and the path clearer. Because, although ignorance of intellectual things abounded, especially among the poorer folk; yet the knowledge of divine things, and the light of faith, were stronger and purer. The anima bruta, or earthly mind, was less strongly defined and fixed, so that the anima divina, or heavenly mind, subsisted in more open conditions. Wherefore the souls of those ages of the world, not being enchained to earth as they now are, were enabled to pass more quickly through their avatârs; and but few incarnations sufficed where now many are necessary. For in these days the mind's ignorance is weighted by materialism, instead of being lightened by faith ; and the soul is sunk to earth by love of the body, by atheism, and by excessive care for the things of sense. And being crushed thereby, it lingers long in the atmosphere of earth, seeking many fresh lodgments, and so multiplies 
bodies, the circumstances of each of which are influenced by the use made of the previous one.

25. For every man makes his own fate, and nothing is truer than that Character is Destiny. It is by their own hands that the lines of some are cast in pleasant places, of some in vicious, and of some in virtuous ones, so that there is nothing arbitrary or unjust. But in what manner soever a soul conduct itself in one incarnation, by that conduct, by that order of thought and habit, it builds for itself its destiny in a future incarnation. For the soul is enchained by these pre-natal influences, which irresistibly force it into a new nativity at the time of such conjunction of planets and signs as oblige it into certain courses and incline it strongly thereto. But if the soul oppose itself to these influences and adopt some other course, - as it well may to its own real advantage, -it brings itself under a "curse" for such period as the planets and ruling signs of that incarnation have power. But though this means misfortune in a worldly sense, it is true fortune for the soul in a spiritual sense. For the soul is therein striving to atone and make restitution for the evil done in its own past ; and thus striving, it advances towards higher and happier conditions. Wherefore man is, strictly, his own creator, in that he makes himself and his conditions, according to the tendencies he encourages. The process of such reformation, however, may be a long one. For, tendencies encouraged for ages cannot be cured in a single life-time, but may require ages for their cure. And herein is a reflection to make us as patient towards the faults of others, as it ought to make us impatient of our own.

26. The doctrine of the soul is embodied in the parable of the Talents. Into the soul of the individual is breathed the Spirit of God, divine, pure, and without blemish. It is God. And the individual has, in his earth-life, to nourish 
that Spirit and feed it as a flame with oil. When we put oil into a lamp, the essence passes into and becomes flame. So is it with the soul of him who nourishes the Spirit. It grows gradually pure and becomes Spirit. By this spirit the body is enlightened as a lamp by the flame within it. Now, the flame is not the oil, for the oil may be there without the light; yet the flame cannot be there without the oil. The body, then, is the lamp-case, into which the oil is poured; and this, the oil, is the soul, a fine and combustible fluid; and the flame is the Divine Spirit, which is not born of the oil, but is communicated by the hand of God. We may quench this Spirit utterly, and thenceforward we shall have no immortality; but when the lamp-case breaks, the oil will be spilt on the earth, and a few fumes will for a time arise from it, and then it will expend itself, leaving at last no trace. Thus, as in the parable of the Talents, where God has given five talents, man pays back ten; or he pays hack nothing, and perishes.

27. Some oils are finer and more combustible than others. The finest is that of the soul of the poet; and in such a medium the flame of God's Spirit burns more clearly and powerfully and brightly, so that sometimes mortal eyes can hardly endure its lustre. Of such a one the soul is filled with holy rapture. He sees as no other man sees; and the atmosphere about him is enkindled. His soul becomes transmuted into flame; and when the lamp of his body is shattered, his flame mounts and soars, and is united to the Divine Fire. ${ }^{4}$

\section{PART IV.}

28. We come to treat of that from which the soul of the individual proceeds, and of which it consists. For, ${ }^{4}$ See C.W.S., part. i., No. xliv., at p. 178. 
as already observed, it is upon the nature of this that our potentialities depend. Let us, then, for a while, ignoring the universe of things, cast our minds backward to the point wherein, prior to Existence, substance necessarily subsists alone and undifferentiate, and pure Being is all.

29. That which subsists before the beginning of things, is necessarily the potentiality of things. This necessarily is homogeneous. As the Substance of things, and pervaded by Life, it is Living Substance ; and being homogeneous, it is One. But, consisting of Life and Substance, it is Twain. Constituting the life and substance of Persons, it is necessarily personal; and being self-subsistent, infinite, eternal and personal, it is God; and God is Twain in One. By virtue of the potency of this duality, God subsists and operates. And every monad of God's substance possesses the potency of Twain. Wherever are Life and Substance, there is God. Wherever God is, there is Being; and wherever Being is, there is God; for God is Being. The universe is Existence, that is, God manifested. Prior to the universe, God subsisted unmanifest. Subsistence and Existence, these are the two terms which denote respec. tively God in God's Self, and God in Creation.

30. Before the beginning of things, the great and invisible God alone subsisted. There was no motion, nor darkness, nor space, nor matter. There was no other than God, the One, the Uncreate, the Self-subsistent, Who subsisted as invisible Light.

3r. God is Spirit, God is Life, God is Mind, God is the Subject and Object of mind: at once the thought, the thinker, and that which is thought of. God is positive and personal Being; the potential Essence of all that is or can be ; the one and only Self; that alone in the universe which 
has the right to say " $\mathrm{I}$. " Wherever a Presence is, there is God; and where God is not, is no Being.

32. In God subsist, in absolute plenitude and perfect equilibrium, all qualities and properties which, opposed to and yet corresponding with each other, constitute the elements masculine and feminine of existence. God is perfect will and perfect love, perfect knowledge and perfect wisdom, perfect intelligence and perfect sympathy, perfect justice and perfect mercy, perfect power and perfect goodness. And from God, as original and abstract humanity, proceeds the derived and concrete humanity which, when perfected, manifests God. God is light, truth, order, harmony, reason; and God's works are illumination, knowledge, understanding, love, and sanity. And inasmuch as anything is absolute, strong, perfect, true, insomuch it resembles God and is God. Perfect and complete from eternity, God is beyond possibility of change or development. Development pertains only to the manifestation of God in creation. As God is one, so is God's method one, and without variation or shadow of turning. God works from within outwards; for God's kingdom is within, being interior, invisible, mystic, spiritual. And God's Spirits, the Spirits of the Invisible Light, are Seven:- the spirit of wisdom, the spirit of understanding, the spirit of counsel, the spirit of power, the spirit of knowledge, the spirit of righteousness, and the spirit of divine awfulness. These are the Powers, or Elohim, of God. They are co-equal and co-eternal. Each has in itself the nature of the whole. Each is a perfect entity. Of them all is the whole of God's substance pervaded. And in their individual manifestations they are the Gods.

33. In God, before the beginning, all things visible and invisible were potential; and of God's fulness have we all 
received. Before the beginning negation was not. There was no other than God.

34. As Living Substance, God is One. As Life and Substance, God is Twain. HE is the Life, and SHE is the Substance. And to speak of Her, is to speak of Woman in her supremest mode. She is not "Nature"; Nature is the manifestation of the qualities and properties with which, under suffusion of the Life and Spirits of God, Substance is endowed. She is not Matter; but is the potential essence of Matter. She is not Space; but is the within of space, its fourth and original dimension, that from which all proceed, the containing elenent of Deity, and of which space is the manifestation. As original Substance, the substance of all other substances, She underlies that whereof all things are made; and, like life and mind, is interior, mystical, spiritual, and discernible only when manifested in operation. In the Unmanifest, She is the Great Deep, or Ocean, of Infinitude, the Principium or Archë, the heavenly Sophia, or Wisdom, Who encircles and embraces all things; of Whom are dimension and form and appearance; Whose veil is the astral fluid, and Who is, Herself, the substance of all souls.

35. On the plane of manifestation, as the Soul macrocosmic and microcosmic, She appears as the Daughter, Mother, and Spouse of God. Exhibiting in a perfect Humanity the fulness of the life she has received of God, she is mystically styled the Blessed Virgin Mary, and in token of her Divine Motherhood and heavenly derivation and attributes, is represented as clad in celestial azure, and bearing in Her arms the infant Man, in whom, regenerate and reborn of Her own immaculate substance, the universe is redeemed. In Her subsist inherently all the feminine qualities of the Godhead. As Venus, the brightest of the 
mystic Seven who represent the Elohim of God, She corresponds to the third, the spirit of counsel, in that counsel is wisdom, and love and wisdom are one. Thus, in mystical art She is portrayed as Aphrodite the Sea-Queen, and Mary the Star of the Sea, and as the soul from whose pure intuition of God proceeds the perfected man. Correspondingly, in mystical science She appears as Sodium, or salt, whose ray in the spectrum, as the place of Venus among the planets, is the third, whose light is the brightest, and whose colour is the yellow. Among the metals, copper is dedicated to Venus. For of copper the crystals are the deep sea-blue. And, inasmuch as She, as love, is the enlightener, and as salt the purifier, and the pure in heart see God, so is its sulphate a balm for ailing eyes. As Pallas or Minerva, She is "Our Lady of Victories," adversary of demons and dragons, wearing the panoply of heaven, and the insignia of wisdom and righteous war. As Isis or Artemis, She is preeminently the Initiator, and the Virgin clothed in white, standing on the Moon, and ruling the waters.

36. Also is She "Mother of Sorrows," whose bitterness pervades all things below; and only by her salting with affliction, purification by trial, and purchase of wisdom by dear-bought experience, is the perfection that is of Her attained. Nevertheless She is also "Mother of Joys," since Her light is gilded by the solar rays; and of Her pain and travail as the soul in the individual, comes the regeneration of Her children. And She is for them no more a sea of bitterness when once their warfare with evil has been accomplished; for then is She "our Lady, Glory of the Church triumphant." Thus in the Microcosm.

37. In the Macrocosm She is that Beginning or Wisdom wherein God makes the heavens and the earth; the substantial waters upon whose face $\mathrm{He}$, the Energising Will, 
moves at every fresh act of creation, and the ark or womb from which all creatures proceed. And it is through the "gathering together," or coagulation, of Her " waters," that the "dry land" of the earth or body, which is Matter, appears. For She is that spiritual substance which, polarising interiorly, is-in the innermost-God; and coagulating exteriorly, becomes - in the outermost-Matter. And She, again, it is, who as the soul of humanity, regaining full intuition of God, overwhelms the earth with a flood of Her waters, destroying the evil and renewing the good, and bearing unharmed on Her bosom the elect few who have suffered Her to build them up in the true image of God. Thus to these is She "Mother of the Living."

38. And as, on the plane physical, man is not Manbut only Boy, rude, froward, and solicitous only to exert and exhibit his strength-until the time comes for him to recognise, appreciate, and appropriate Her as the woman; so on the plane spiritual, man is not Man-but only Materialist, having all the deficiencies, intellectual and moral, the term implies-until the time comes for him to recognise, appreciate, and appropriate Her as the Soul, and, counting Her as his better half, to renounce his own exclusively centrifugal impulsions, and yield to Her centripetal attractions. Doing this with all his heart, he finds that She makes him, in the highest sense, Man. For, adding to his intellect Her intuition, She endows him with that true manhood, the manhood of Mind. Thus, by Her aid obtaining cognition of substance, and from the phenomenal fact ascending to the essential idea, he weds understanding to knowledge, and attains to certitude of truth, completing thereby the system of his thought.

39. Rejecting, as this age has done, the soul and her intuition, man excludes from the system of his humanity the 
very idea of the woman, and renounces his proper manhood. An Esau, he sells, and for a mess of pottage, his birthright, the faculty of intellectual comprehension. Cut off by his own act from the intuition of Spirit, he takes Matter for Substance; and sharing the limitations of Matter, loses the capacity for knowledge. Calling the creature thus self-mutilated, Man, the age declares by the unanimous voice of its exponents, that Man has no instrument of knowledge, and can know nothing with certainty, excepting -for it is not consistent even in this-that he can know nothing. Of this the age is quite sure, and accordinglycomplacent in its discovery-styles itself Agnostic. And, as if expressly to demonstrate the completeness of its deprivation in respect of all that goes to the making of Man, it has recourse to devices the most nefarious and inhuman on the pretext of thereby obtaining knowledge.

40. Whereas, had but the soul received the recognition and honour her due, no pretext had remained for the abominations of a science become wholly materialistic. For, as the substance and framer of all things, she necessarily is competent for the interpretation of all things. All that she requires of man, is that she be duly tended and heeded. No summit then will be too lofty of goodness or truth, for man to reach by her aid. For, recognised in her plenitude, she reveals herself in her plenitude; and her fulness is the fulness of God.

\section{PART V.}

4I. The wise of old, who, exalting the Woman in themselves, attained to full intuition of God, failed not to make recognition of Her in the symbols whereby they denoted Deity. Hence the significance of the combination, universal from the first, of the symbols $\mathrm{I}, \mathrm{O}$, the unit and the 
cipher, in the names designative of Deity. For, as the Line of force, and the Circle of comprehension and multiplication, these two represent at once Energy and Space, Will and Love, Life and Substance, Father and Mother. And though two, they are one, inasmuch as the circle is but the line turning round and following upon itself, instead of continuing into the abyss to expend its force in vain. Thus Love is self-completion by the union of corresponding opposites in the same substance, and Sex has its origin in the very nature of Deity. The principle of duality is for the Kabbalists - the heirs and interpreters of Hebrew transcendentalism - the true God of Hosts. Hence the universal use of its emblems in religious worship, wherein nations gave the preference to the one or to the other, according to their own characteristics.

42. While these symbols conjoined find expression in the terms Jehovah or Yahveh, Jove, Jao, and numerous similar appellations of Deity, the names Zeus, Dyaus, Theos, and Deus represent but the forceful and masculine element in the feminine azure sphere of the sky, the electric flash from the bosom of the heavens. That name of Deity which, occurring in the Old Testament, is translated the Almighty, namely, El Shaddai, signifies the Breasted God, and is used when the mode of the Divine nature implied is of a feminine character. The arbitrary and harsh aspect under which Jehovah is chiefly presented in the Hebrew Scriptures, is due, not to any lack of the feminine element either in His name or in His nature, or to any failure on the part of the inspired leaders of Israel to recognise this quality ; but to the rudimentary condition of the people at large, and their consequent amenability to a delineation of the sterner side only of the Divine character. It is according to the Divine order that this, 
the masculine element of existence, should be the first to find exercise. In the initiation of any system, the centrifugal, or repellent, mode of force must precede the centripetal, or attractive, mode; since only when the former has accomplished its part, is there opportunity for the exercise of the latter. True, the Love Who prompts to creation is present from the beginning; but She reserves the manifestation of Herself until the subject of Her creative impulsion is able to bear its part in the recognition of Her. First Will, therefore, then Love; first Projection, then Recall ; first Expansion, then Contraction ; first Centrifugal, then Centripetal ; first Motor, then Sensory; first Intellectual, then Intuitional ; first Sensible, then Spiritual ; in short, first Man and then Woman,-such invariably is the order by which the Universal Heart of existence manifests its essential dualism of nature and operation. And in the sequence set forth in the Bible-the sequence of Law and Gospel, of Old Testament and New-the same rule prevails. To the masculine function is accorded precedence in point of time; to the feminine, in point of dignity. And it is thus that the manifestation of the Divine will and power in Creation is followed by the manifestation of the Divine love and wisdom in Redemption, and that the agent of this last is always the "woman." She it is who, by Her Intuition of God, bruises the head of the Serpent of Matter, and Her sons they are who get the victory over him.

43. Even where not yet recognised by men in general, there were always some by whom the true character of Deity in this respect could be discerned. And to these are due all those utterances in which the mystical Scriptures express the justice, mercy, long-suffering, and other qualities of the Divine nature, which, in being moral and of the soul, are feminine, and when manifested of the Spirit 
as persons, take form, not as "Gods," but as "Goddesses." They to whom this truth was known were prophets; and they spoke, not of that which appertains to any one period, but of that which is eternal, though finding expression more or less palpable at various periods. And that whereby they knew so much, was not the outer sense and reason, but the inner perception and recollection-the knowledge, that is, which the soul of the individual has of her own larger self, the Soul of the Universal. For only Soul can read Soul. And only he is a prophet who has acquired the knowledge of his own soul. And that which above all else the Soul tells him, is that God is, first and foremost, Love ; and that, inasmuch as God is the Substance of humanity, whatever subsists in the Divine nature must, in due course, first in the individual and next in the race, find full expression and recognition.

44. If it be asked whether God can indeed find such expression in man, and, if so, how so great a marvel comes about, we reply that it is precisely the purpose of these lectures to afford demonstration on both points. For the object of the system under exposition is this, and no more, no less. For that object is-as was the object of all sacred mysteries, whether of our Bible or other-to enable man anew so to develop the Soul, or Essential Woman, within him, as to become, through Her, a perfect reflection of the universal Soul, and made, therefore, in what, mystically, is called the image of God.

45. An illustration will conduce to the comprehension of this. We are, let us suppose, in a meadow covered with grass and flowers. It is early morning, and everything is bespangled with dew. And in each dew-drop is everything reflected, from the sun itself down to the minutest object. All reflect God. All is in every dew-drop. And 
God is in each individual according to his capacity for reflecting God. Each in his degree reflects God's image. And the capacity of each, and the degree of each, depend upon the development and purity of his soul. The soul that fully reflects the sun, becomes itself a sun, the brightness of the Divine glory and the express image of the Divine person.

46. Such, in all mystical Scriptures, has ever been the mode in which perfected souls have been regarded. For, in being the redeeming element in man, that whereby he escapes from the dominion of spiritual darkness and death,-from the limitations, that is, of an existence merely material,-the soul is as a spiritual sun, corresponding in all things with the solar orb. Wherefore all they who, by virtue of their constituting for men a full manifestation of the powers of the soul, have been to them as a redeeming sun,- have been designated sungods, and invested with careers corresponding to the apparent annual course of the sun Between the phenomena of this course and the actual history of the perfected soul is an exact correspondence, requiring for its recognition but due knowledge of both. And it is because the soul's history is one, and this is a history corresponding with the sun's, that all those who have earned of their fellows the supreme title of Saviour of men, have been invested with it, and represented as having exhibited the same phenomena in their own lives. Thus the history ascribed alike to Osiris, Zoroaster, Krishna, Mithras, Pythagoras, Buddha, and Jesus, has not, as sciolists vainly imagine, been plagiarised in one case from another, or borrowed from some common source in itself unreal; but it has been lived, spiritually, by the men themselves indicated by those names. And, being the history of the soul of the Man Regenerate, it corresponds 
to that of the sun,-the vitalising centre of the physical system,-and has accordingly been described in terms derived from the solar phenomena as indicated in the zodiacal planisphere. Thus the soul's history is written in the stars ; and the heavens are her chroniclers, and tell the glory at once of her and of God. A Bible is always a hieroglyph of the soul. And the Zodiac is simply the first and most stupendous of Bibles,-a Bible which, like all other Bibles, was written by men who, attaining to the knowledge of their own souls, attained to that of all souls, and of God, Who is the Life and Substance of souls.

47. And these were men who followed steadfastly that Perfect Way, which is in the power of each, according to his degree, to follow, until, by the development of their own natural potentialities, they attained to that which, mystically, is called the Finding of Christ. And this is the perfection which, in that it is God, is its own exceeding great reward. For the "gift of God is eternal life." As God is One, so is the soul one; and these are One also both in nature and method. All that is in God as universal subsists also in God as individual. Wherefore God is nothing that man is not. And what man is, that God is likewise. God withholds nothing of God from man. For "God is Love," and "Love hath nothing of her own."

48. This is the doctrine of the Soul, mystically called the Woman. It is a doctrine which, by showing men that of which they are made, and therefore that which they have it in them to be, makes them, when they receive it, heartily ashamed of being what, for the most part, they are. 


\section{LECTURE THE THIRD. ${ }^{1}$}

\section{THE VARIOUS ORDERS OF SPIRITS; AND HOW TO DISCERN THEM.}

\section{PART I.}

I. WE have spoken of the Soul and of Spirit. We come now to speak of Spirits; for the understanding of these also is necessary to a true doctrine concerning Existence. But though speaking especially of Spirits, it will be necessary to refer also to Souls; for though Spirits, properly so called, have not souls, Souls have spirits. In either case, however, we shall treat mainly of the Unembodied, or the Disembodied. And as the region or sphere which is immediately contiguous to the Material, and which we ourselves enter upon quitting the Material, is the Astral, it is this, and its occupants, which will first engage our attention.

2. To understand fully the place and value of this sphere, it is necessary to have in the mind a clear conception of the places and values of all the spheres which are comprised in and which constitute that manifestation of Being which is termed Existence. To this end we will commence with the following succinct recapitulation. The Spirit and Soul, which are original life and substance, are Divine and

1 This lecture was written by Edward Maitland mainly from Illuminations received by Anna Kingsford; and was delivered by him on Wednesday the Ist June, I88I (Life of $A$. $K$., vol. ii., pp. 16, 17, 32). 
uncreated. The astral and material bodies are the "created"-that is, the manifested-part. The astralwhich is called also the sideral, the odic, the magnetic, the fiery-is fluidic, and constitutes the bond between the soul and the material body. It is the original body, being that which makes and that which becomes. The original, permanent individual consists of soul and spirit; and when manifested it is by means of the astral or fluidic body, of which the material or fixed body is the outer manifestation -the manifestation, as it is called, in ultimates.

3. Every creation, or complete manifested entity, whether it be macrocosmic or microcosmic, is a compound of two dualisms, which are respectively celestial and terrestrial, or spiritual and material. The celestial, or kingdom of heaven, which consists of soul and spirit, is within. And the terrestrial, or kingdom of this world, which consists of astral body-the seat of the anima bruta-and of phenomenal body, is without. Of these two dualisms, each is to the other the Beyond. And between them, saving only where one and the same Divine Will-the will which has its seat in, and which is, the Spirit-pervades the whole being, is antagonism. They are respectively the spiritual man and the natural man. But in the suffusion of the entire personality thus constituted, by one and the same Divine Will, consists what mystically is termed the At-one-ment, or reconciliation between man and God, but which is commonly called the Atonement.

4. As the whole is, thus, fourfold, so, with the exception of the spirit, are the parts. The external, material body, whether of planet or of man, is fourfold in that it is gaseous, mineral, vegetable, animal. The astral body, or perisoul, is fourfold, being magnetic, purgatorial, limbic, cherubic,-terms presently to be explained. The soul is 
fourfold, namely, elemental, instinctive, vital, rational. And the spirit is threefold, or triune, because there is no external to spirit. Being threefold, it is the Essence, the Father, the Word ; and is desirous, willing, obedient. And being God, it is one, because God is one. And thus the magical number, mystically called the number of Perfection and of the Woman, the number Thirteen, derives its sanctity from the constitution of the perfected individual.

5. The astral sphere, zone, or circulus, - variously called the perisoul, the magnetic, sideral, and odic fluid or body, is the same with the "wheel" of Ezekiel, of which the four living creatures are the four elemental spirits. It contains four orders of entities, which are represented by four magnetic circuli or wheels encircling the earth, and full of lives. The highest and uppermost of these circuli is that of the elemental spirits or "winged creatures"; the second is that of the souls; the third is that of the shades; and the fourth and lowest is that of the magnetic spirits commonly called astrals.

6. These circuli correspond to Air, Water, Earth, and Fire, beginning at the outer and uppermost and going inwards and downwards. The magnetic emanations, or astrals, are under the dominion of the Fire. They are not souls, or divine personalities; they are simply emanations or phantasms, and have no real being.

7. Every event or circumstance which has taken place upon the planet, has an astral counterpart or picture in the magnetic light; so that, as already said, there are actually ghosts of events as well as of persons. The magnetic existences of this circle are the shades, or manes, of past times, circumstances, thoughts, and acts of which the planet has been the scene; and they can be evoked and conjured. The appearances on such occasions are but shadows left 
on the protoplasmic mirror. This order, then, corresponds to that of Fire, and is the fourth and lowest.

8. The next circulus, the third, with its spirits, corresponds to Earth, and contains the shades, Lares and Penates, of the dead. These are of many different kinds. Some are mere shades, spiritual corpses, which will soon be absorbed by the fourth circulus just described and become mere magnetic phantoms. Some are "ghosts," or astral souls not containing the divine particle, but representing merely the "earthly minds" of the departed. These are in Limbo or the "Lower Eden." Others are really Souls, and of the celestial order, or anima divina, who are in Purgatory, being bound to the astral envelope, and unable to quit it. They are sometimes called "earth-bound spirits," and they often suffer horrible torments in their prison ; not because this circulus is itself a place of torment, but because to the anima divina the unredeemed body, whether material or astral, is a "house of bondage" and chamber of ordeal. The strong wills, love, and charity of those on earth may relieve these souls and lessen the time of their purgatorial penance. Of some of them the retention is due to wilful ignorance, of others to sensuality, and of others to crimes of violence, injustice, and cruelty.

9. This sphere is also inhabited by a terrible class, that of the "devils," some of whom are of great power and malice. Of these the souls are never set free; they are in what is called "Hell." But they are not immortal. For, after a period corresponding to their personal vitality and the strength of their rebellious wills, they are consumed, and perish for ever. For a soul may be utterly gross at last, and deprived of all spirit of the Divine order, and yet may have so strong a vitality or mortal spirit of its own, that it may last hundreds of years in low atmospheres. 
But this occurs only with souls of very strong will, and generally of indomitable wickedness. The strength of their evil will, and the determination to be wicked, keep them alive. But, though devils, they are mortal, and must go out at last. Their end is utter darkness. They cease to exist. Meanwhile they can be evoked by incantation. But the practice is of the most dangerous and wicked kind; for the endeavour of these lost spirits is to ruin every soul to which they have access.

I0. In the sense ordinarily understood, there is no personal Devil. That which, mystically, is called the Devil, is the negation and opposite of God. And whereas God is I AM, or positive Being, the Devil is NOT. He is not positive, not self-subsistent, not formulate. God is all these ; and the Devil, in being the opposite of these, is none of them. God, as has been said, is Light, Truth, Order, Harmony, Reason; and God's works are illumination, knowledge, understanding, love, and sanity. The Devil, therefore, is darkness, falsehood, discord, and ignorance; and his works are confusion, folly, division, hatred, and delirium. He has no individuality and no being. For he represents the Not-being. Whatever God is, that the Devil is Not. Wherever God's kingdom is not, the Devil reigns.

Ir. It is the principle of Not-being which, taking personality in man, becomes to him the Devil. For by divest. ing him of his divine qualities, actual or potential, it makes him in the image of God's opposite, that is, a devil. And of such a one the end is destruction, or, as the Scriptures call it, eternal death. And this of necessity from the nature of the case. For evil has not in itself the element of selfperpetuation. God alone is Life or the principle of eternal generation. And, as Life, God comprises all things neces- 
sary to life, to its production, that is, to its perfection, and to its perpetuation. And God is Spirit, whereof the antithetical ultimate is Matter. The Devil is that which gives to Matter the pre-eminence over Spirit. That is, since there is nothing but God's creation to be set in opposition to God, the Devil exalts the mere material of creation in the place of God. Of such preference for Matter over Spirit, for appearance over reality, for Seeming over Being, the end is the forfeiture of reality, and therein, of Being. In representing, therefore, the contest between good and evil,-a contest corresponding to that between light and darkness,-creation represents the contest between Being and Not-being. To "give place to the Devil," is thus, in its ultimate result, to renounce Being. And, as a free agent, man is able to do this. God, while giving to all the opportunity and choice, compels no one to remain in Being. God accepts only willing service; and there is no such thing as compulsory salvation. God-that is Good, - must be loved and followed for the sake of God and Good, not through fear of possible penalties, or hope of possible rewards.

1 2. Now the sign, above all others, whereby to distinguish the Devil, is this:-God is, first and foremost, Love. The Devil, therefore, is, before all else, Hate. He is to be known, then, first by the limitation, and next by the negation of Love.

13. The Devil is not to be confounded with "Satan," though they are sometimes spoken of in Scripture as if they were identical. The truth concerning "Satan" belongs to those greater mysteries which have always been reserved from general cognition. ${ }^{2}$

14. Notwithstanding that the Devil is the Non-entity ${ }^{2}$ See C.W.S., part ii., No. xv., p. 275. 
above described, he is the most potent, and, indeed, sole power of evil. And no one is in so great danger from him, as he who does not believe in him. The whole function of the Christ is to oppose, and rescue men from him. And therefore it is written, "For this cause is Christ manifest, that he might destroy the works of the devil."

15. But, be it remembered, though there is no self-subsistent, positive evil being, - such as the Devil is ordinarily presented,-but only the negation of God,-which is to God what darkness is to light, and the outermost void to the solar system, - there are evil spirits, the souls of bad men on their downward way to final extinction. And these are wont to associate themselves with persons in the flesh for whom they have affinity. And they do this partly in order to gratify their own evil propensities by inciting to wickedness and mischief, and partly to obtain from them the vitality necessary to prolong their own existence. For, as their career approaches its end, they become so low in vitality that a sentence of expulsion from the person in whom they have taken refuge may involve their immediate extinction, unless they can find other location, - a contingency obviously contemplated in the case of the Gadarene demoniacs. The ailments, physical or mental, of men are sometimes caused or aggravated by extraneous malignant entities of this order. And occultists hold that they even share with the elementals the power of inducing the conditions under which sudden storms and other elemental disturbances occur. Evil spirits have no chief, no organisation or solidarity; nothing that corresponds to God. The worse they are, the lower and the nearer to extinction. The conditions which attract them are due to men themselves, and may be the result of prenatal misconduct.

16. The next and second circulus of the planet-that 
which corresponds to the Water-is the kingdom of the souls which are mystically described as being in "Brahma's bosom." These are the purified who are at rest before seeking re-incarnation. This circulus is not confined to human souls. Therein are all creatures, both great and small, but without "fiery" envelope. Between these and the kingdom of the earth-bound souls in prison to their own astral bodies, a great gulf is fixed; and they cannot pass from one to the other save on accomplishing their purgation. "Thou comest not out thence until thou hast paid the last mite." The souls in the second circulus, however, though purified, are still "under the elements." For purification is not regeneration, though a necessary step towards it. And not being ready for transmutation into spirit, they must, sooner or later, seek fresh incarnations. They are, therefore, still in the sphere of the planet. Whereas the regenerated or transmuted souls have passed beyond the astral zone altogether, and it contains no trace of them. This second circulus was placed under the dominion of the sea-god Poseidon, because, first, being protoplasmic and devoid of any limiting principle, water corresponds to the substance of the Soul. Next, it is the baptismal symbol of purification from materiality. And, thirdly, it is the source of life and the contrary of fire. "Let Lazarus dip the tip of his finger in water, and cool my tongue," cries the soul in the prison of the "fiery" body to the soul in the zone of the water.

17. To the first and highest circulus belong the spirits of the elements, which pervade all things, not only of the Macrocosmic planet, but of the Microcosm man. Of these elementals, the air-spirits preside over the function of respiration, and the organs which accomplish it. The waterspirits preside over the humours and secretions of the body, 
and in particular the blood. The earth-spirits have for their domain the various tissues of the body. And animal heat, assimilation, and nutrition are dependent on the fire-spirits.

18. An initiate of the highest grade, one who has power to hush the storm and still the waves, can, through the same agency, heal the disorders and regenerate the functions of the body. And he does this by an impulsion of will acting on the magnetic atmosphere, every particle of which has a spirit capable of responding to the human will.

19. The common phrase, "Spirits of the dead," is incorrect. There are only shades of the dead and souls of the dead. But these last are of two kinds, the earthly, or anima bruta, and the heavenly, or anima divina. The shade, larva, or spectre-which is the outer element of the ghost-is always dumb. The true "ghost" consists of the exterior and earthly portion of the soul, that portion which, being weighted with cares, attachments and memories merely mundane, is detached by the soul and remains in the astral sphere, an existence more or less definite and personal, and capable of holding, through a Sensitive, converse with the living. It is, however, but as a cast-off vestment of the soul, and is incapable of endurance as ghost. The true soul and real person, the anima divina, parts at death with all those lower affections which would have retained it near its earthly haunts, and either passes on at once to higher conditions, attaining its perfection by post-mortem evolution, or continues its peregrinations in a new body. This, the true soul, may, by Divine permission, and on special occasions, communicate with the living, returning for that purpose from the purgatorial world; but such an event is of the rarest and most solemn kind. Reincarnation pertains only to the true soul. The astral soul or fluidic envelope, does not again become incarnate; so 
that they are not in error who assert that a person is never twice incarnate. That which transmigrates is the essential germ of the individual, the seat of all his divine potencies. In some this exists as a mere dim spark, and in others as a luminous sun.

20. Metempsychosis, in its strict sense, consists in the overshadowing of a soul already incarnate, by one which has completed its transmigrations, and become freed from Matter and all planetary bonds. This divine overshadowing differs both in kind and in degree from those astral visitations which are familiar to so many under the names of "guides," and "controls," and which, as will presently be shown, are often not even "ghosts," but mere astral mirages of the seer or the invoker. When not of this kind, the control is either of the spirits known as Elementals, or of the shades or larva of the recently dead, the Manes, Lares, and Penates of the Latins. The river Lethe, of which the dead are said to drink in order to obtain oblivion of their past before returning to new earth-bodies, represents the process of separation between the anima divina and anima bruta, whereby the former doffs for a time the garment of its memory. Souls may, according to circumstances, either become re-incarnate immediately after such divestment of their astral part, or proceed to accomplish their purification in the purgatorial world. ${ }^{3}$

$2 \mathrm{I}$. It is as penance or expiation that souls re-descend from the human into the animal form. This return occurs through the forfeiture of the divine-human spirit, so that the spirit itself does not incur dishonour. True, the penance involves disgrace; but the disgrace is not in the penance, but in the sin through which the need for the penance is incurred. 'The man who sullies his humanity

${ }^{3}$ See C.W.S., part i., No. xl., p. 156. 
by cruelty or impurity, is already below the grade of humanity; and the form which his soul assumes is the mere natural consequence of that degradation. Form is the expression of qualities. These are dependent upon the condition of substance, so that the sou takes necessarily its form according to its condition. And this is dependent upon the will or affections of the individual. Wherefore it is an error to hold "Nature" responsible for fierce and horrible creatures. All that "Nature" does, is to enable creatures to take form according to the image in which they have made themselves by the tendencies they have voluntarily encouraged. She allows that which is interior to the individual to manifest itself exteriorly. Were this not so, no character of any creature could be known by its appearance. The "mark set upon Cain" has its counterpart in the stripe of the tiger; and the crustacea denote selfish spirits, who are hard exteriorly to all the world, and soft only interiorly to themselves. The adept in Psychology can tell whether the soul of an animal is on its upward or its downward path. He can discern also the animal beneath the human form, when the progressing soul has not yet wholly shed the animal nature; for the exterior form of humanity is reached in full while its interior reality is reached in part only. Thus, for the adept there are more animals than men to be seen in the streets of a city, despite the humanity of their forms. The individual is already partly human before it has ceased to wear the form of a rudimentary man, that is, of an animal. The matrix can bring forth only its own kind, in the semblance of the generators; and as soon as the human is attained, even in the least degree, the soul has power to put on the body of humanity. Thus, too, the adept can see the human shape in creatures under torture in the physiological 
laboratory. He can discern the potential form of a man, with limbs and lineaments resembling those of his tormentors, hidden within the outward form as a child in its mother's womb, and writhing and moaning under the lacerations of the knife. And he sees also the tiger and the devil rapidly developing within the still human forms of the torturers, and knows certainly that to such grades they will descend on quitting the human. For he knows, having learned it by the long experiences of his own soul, that God, who is before all else Love, is also before all else Justice, and this because God is Love; for Justice is Sympathy. Wherefore, by the inexorable law of Justice, he who makes existence a hell for others, prepares, inevitably, a hell for himself, wherein he will be his own devil, the inflictor of his own torments. His victims will, indeed, find compensation at the Divine hands; but for him will be no escape, no alleviation, until "he has paid the last mite." For the pitiless, and for the pitiless alone, there is no pity. Such, the adept of spiritual science knows absolutely, is the doom that awaits both the tormentor himself, and, in their degree, those who, by accepting the results of his practice, consent to his method.

22. That which leads to the loss of the soul, is not isolated crime, however heinous, or even a repetition of this; but a continued condition of the heart, in which the will of the individual is in persistent opposition to the Divine Will; for this is a state in which repentance is impossible. The condition most favourable to salvation, and speedy emancipation from successive incarnations, is the attitude of willing obedience,-freedom and submission. The great object to be attained is emancipation from the body, - the redemption, that is, of Spirit from Matter. 


\section{PART II.}

23. We will now speak particularly of that order of spirits by which, ordinarily, "mediums" are "controlled"; or, more correctly, sensitives are influenced, since these spirits, which are called astrals, have no force, and cannot exercise the least control. Born of the emanations of the body, they occupy the perisoul, or fluidic astral and magnetic bond which unites the soul to the body.

24. In this fluid, which is the magnetism of the earth, - the lowest circulus of the Fire,-and which may be more clearly denoted by the term latent light,-analogous to latent heat,- take place those changes, currents, and modifications which result and are expressed in the phenomena - of late days familiar to numbers-produced by astral spirits. Through this fluidic element are passed two currents, one refracted from above, and the other reflected from below, - one being celestial, as coming direct from the spirit, and the other terrestrial, as coming from the earth or body ; and the adept must know how to distinguish the ray from the reflection. When a medium, or sensitive, passes into the negative, and thence into the somnambulic state, the mind of such sensitive is controlled by the will of the magnetiser. The will of this second person directs and controls the procession and expression of the image perceived. But the magnetiser, unless an adept, will not be able to discern the true origin of the images evoked.

25. Now, in this magnetic sphere are two orders of existences. Of these orders, one is that-already mentioned-of the shades of the dead; the other consists of reflects of the living; and the difficulty of distinguishing between these two orders is, to the uninitiated, a source of error. Error of a most serious kind arises through the 
complex character of the astral region itself, and the variety of the grades of spirits by which every division is tenanted. Spirits of the sub-human order, moreover, are wont, under control of the wish of their invokers, to personate spirits of a higher grade.

26. It will thus be seen that the elements of deception are, broadly, twofold. In the first place, to enter the astral region, is not to enter the celestial; and the ray reflected from below, and which bears the imprint of the body, may easily be mistaken for the ray refracted from above, and which alone is pure and divine. In the second place, the astral region itself contains various orders of spirits, of which some only bear relation to actual souls, and the others consist of phantasmal and illusory reflects. These latter-the astral spirits properly so called-are in no cases entities, or intelligent personalities ; but are reflections, traces, echoes, or footprints of a soul which is passing, or which has passed, through the astral medium; or else they are reflections of the individual himself who beholds or who evokes them, and may thus represent an equal compound of both sensitive and magnetiser.

27. Now, the atmosphere with which a man surrounds himself-his soul's respiration-affects the astral fluid. Reverberations of his own ideas come back to him. His soul's breath colours and savours what a sensitive conveys to him. But he may also meet with contradictions, with a systematic presentation of doctrine or of counsels at variance with his own personal views, through his mind not being sufficiently positive to control all the manifestations of the electric agent. The influence of the medium, moreover, through which the words come, interposes. Or, as is often the case, a magnetic battery of thought has overcharged the element and imparted to it a certain current. 
Thus, new doctrines are "in the air," and spread like wildfire. One or two strongly positive minds give the initiative, and the impulse flies through the whole mass of latent light, correspondingly influencing all who are in relation with it.

28. The merely magnetic spirits are like mists which rise from the damp earth of low-lying lands, or vapours in high altitudes upon which if a man's shadow falls he beholds himself as a giant. For these spirits invariably flatter and magnify a man to himself, telling one that he is, or shall be, a king, a Christ, or the wisest and most famous of mortals ; and that if he will be wholly negative, and give himself up entirely to them, suppressing his own intelligence and moral sense, they will enable him to realise his utmost ambition. Being born of the fluids of the body, they are unspiritual and live of the body. And not only have they no aspirations beyond the body, but they ignore, and even deny, the existence of any sphere above their own. They speak, indeed, of God, especially under the name of Jehovah, but with complete ignorance of its meaning; and they insist on material renderings and applications of any doctrine of which they may catch the terms. They are profuse alike of promises and of menaces, and indulge freely in prophecies. But when informed of their failures they declare that even God cannot surely foresee the future, but can judge only according to apparent probabilities. Of contradictions in their own statements they are altogether unconscious; and be these gross and palpable as they may, they remain wholly unabashed by the disclosure of them. Especially are they bitter against the "Woman." For, in her intuition of Spirit, they recognise their chief enemy. And whenever they attach themselves either to a man or to a woman, they make it their endeavour to exalt the masculine 
or force element, of mind or body, at the expense of the feminine element. And these, generally, are their signs. Is there anything strong? they make it weak. Is there anything wise? they make it foolish. Is there anything sublime? they distort and travesty it. And where suffered to expatiate unchecked, they descend to blasphemy and obscenity without measure, and incite to courses in turn sensuous, vicious, malicious, or cruel, encouraging to gross and luxurious living, - the flesh of animals, and stimulants being especially favourable to their production and nurture. They are the forms beheld in delirium, and are frequent agents in producing the phenomena of hysteria. They are the authors, too, of those hasty impulses by yielding to which people do in a moment mischief which a life-time cannot efface or repair. And, as they live upon the vital spirits of the blood, they deplete the vital energy, and are as vampires to those upon whom they fasten. They are able, moreover, to carry elsewhere the knowledge they get from any one ;being the "powers of the air" spoken of in Scripture, and the "bird that carries the voice and tells the matter." For the term rendered "bird" signifies a winged creature, and implies an astral. Hence one of the reasons for observing secrecy concerning Sacred Mysteries. For, by seeming to have knowledge of these, the astrals are able to persuade and mislead people, mixing up a little truth with dangerous error, and getting the error accepted on the strength of the truth, or of some Divine name or phrase with which they associate it, themselves being ignorant of its import. Being impersonal, they have no organon of knowledge, for this is of Soul, and the astrals have no positive existence, but subsist subjectively in human beings. Having no souls, they are not individuals, and have no idea of right and wrong, true and false, but, like a mirror, reflect what comes 
before them, and, in reflecting, reverse it. Catching any prominent quality in a person's mind, they make the most of it by reflecting and magnifying it. Hence they are not to be heeded. We must heed only the God within. Of the enormous ladder within us, at the apex of which is the Absolute, these magnetic phantasmagoria are at the base.

29. Unable to grasp or conceive of anything beyond the atmosphere of their own circle, the astral phantomsunless under the influence of a strongly positive minddeny altogether the existence of the upper dualism, which, with the lower, constitutes man a fourfold being. They assert, indeed, that man consists of body and soul ; but they mean thereby the material body and earthly mind, and represent these as constituting the man. The soul and spirit, which are really the man, have for them no existence; and they usually refuse, in consequence, to admit the doctrine of Transmigration or Re-incarnation. For, as they are aware, the body and perisoul perish, and the anima bruta cannot transmigrate or become re-incarnate. Their inability to recognise the soul and spirit, leads them to deny the existence of any source of knowledge superior to themselves, and to assert that they themselves are man's true and only inspiring spirits and guardian angels. And one of their favourite devices consists in building up, out of the magnetic emanations of the individual, a form which they present as his own "counterpartal angel" and divine spirit, from whom, say they, he was separated in what -affecting Scripture phraseology-they call the Adamic period of his being, and by reunion with which he attains his final perfection. In this they travesty at once the doctrine of that divine marriage between soul and spirit, which, occurring in the individual, constitutes his final perfection, or Nirvâna ; and the relations of the genius, or 
true guardian angel, with his client. For, being unintelligent, they fail to perceive that perfection is to be attained, not by accretion or addition from without, but only by development or unfoldment from within. Thus the process itself of regeneration, becomes altogether an absurdity in their hands. And in this, as in all other matters, the object of the astrals is to obtain all credit and support for their own order, by substituting for the Spirit $a$ spirit, and this one of themselves.

30. It is to astral instigation, generally, that are due the various communities and sects which have for their basis some peculiar relation between the sexes. That modern form of the cultus of what is called "Free Love," which sets forth, not the human, but the female, body as the temple of God, and with this couples the doctrine of "counterpartal angels," is entirely of astral contrivance. And so also is the notion, far from uncommon, that by abjuring the ordinary marriage relation, and devoting herself wholly to her astral associate, a woman may, in the most literal sense, become an immaculate mother of Christs. It is to their materialisation of this and other doctrines, which properly are spiritual only,-and, notably, as will by and by be shown, of the doctrine of Vicarious Atonement,-that is due the degradation of Christianity from a spiritual to a materialistic, and therein to an idolatrous religion, and its consequent failure, thus far, to accomplish its intended end. But of this more on a future occasion. It is sufficient to add here in this connection, that, not in doctrine only, but also in practice, - as in the formation of habits of life, astral influence is always exerted in the direction of the gross, the selfish, and the cruel. It is always the influence under which men, whether they be conscious of it or not, lower the standard of their conduct, and seek their own 
gratification at the cost of others. Of those hideous blots upon modern life, the frequent sins of violence, greed, and intemperance, the astrals are active promoters. And to them is due in no small degree that extension of the doctrine of vicarious sacrifice-originally their own invention-from the sacerdotal to the social and scientific planes, which has made of Christendom little else than a vast slaughter-house and chamber of torture. No less than the priest of a sacrificial religion, are the butcher, the sportsman, and the vivisector, ministers to the astral in man. Nevertheless, though thus indictable, these spirits are not in themselves evil. They do but reflect and magnify the evil which men harbour and encourage in themselves.

$3 \mathrm{r}$. It is characteristic of the astrals, that they always strenuously insist on the most absolute passivity on the part of those whom they influence or address. This condition of unintelligent passivity must be carefully distinguished from the reasonable reflective state favourable to divine communion, and called the "Night-time of the Soul." Such is the unsubstantiality of the astrals, that the smallest exercise of an adverse will throws them into confusion and deprives them of the power of utterance. They shun a person in whom the flame of the spirit burns up straightly and ardently; but where it spreads out and is diffused, they flock round him like moths. The more negative the mind and weak the will of the person, the more apt and ready he is to receive them. And the more positive his mind and pronounced his will, - in the right direction,- the more open he is to Divine communication. The kingdom of the Within yields, not to indifference and inaction, but to enthusiasm and concentration. Wherefore it is said, "To labour is to pray; to ask is to receive ; to 
knock is to have the door opened." When we think inwardly, pray intensely, and imagine centrally, then we converse with God. When we allow ourselves to be inert and mechanically reflective, then we are at the mercy of the astrals, and ready to accept any absurdity as divine truth.

32. The astrals, it will be useful to many to be assured, not only cannot confer the Divine life, they cannot rise to be partakers of it themselves. In describing them, the exigencies of language compel the use of terms implying personality. But it must be clearly understood that these "spirits" are mere vehicles, and are no more possessed of independent volition or motive than is the electric current by which telegraphic messages are conveyed, and which, like them, is a medium of thought ; or than the air, which, according to circumstances, transmits the germs of health or of disease. Thus, although they are not intelligent personalities, they are often the media of intelligent ideas, and operate as means of communication between intelligent personalities. Ideas, words, sentences, whole systems of philosophy, may be borne in on the consciousness by means of the currents of magnetic force, as solid bodies are conveyed on a stream, though water is no intelligent agent. The minutest cell is an entity, for it has the power of self-propagation, which the astral has not.

33. Few are they, even of the highest orders of mind, who have not at times fallen under astral influence, and with disastrous results. And herein we have the key, not only to the anomalies of various systems, otherwise admirable, of philosophy and religion, but also to those discordant utterances of the most pious mystics, which have so sorely perplexed and distressed their followers. When we have named a Plato, a Philo, a Paul, a Milton, and a Boehme, as conspicuous instances in point, enough will have been 
said to indicate the vastness of the field to which the suggestion applies. Few, indeed, are they who can always find the force to penetrate through the astral and dwell solely in the celestial. Hence, for the true ray refracted from above, men mistake and substitute the false ray reflected from below, foul with the taint of earth, and savouring of the limitations of the lower nature, and, like the image in the glass, exactly reversing the truth. Wherever we find a systematic depreciation of woman, advocacy of bloodshed, and materialisation of things spiritual, there, we may be confident, does astral influence prevail. The profound Boehme frankly admits his own liability in this respect.

34. Though inhabiting the astral region, the spirits called elemental or nature-spirits, and presiding spirits or genii loci, are of very different orders from those just described. Of this last class are the spirits known to all early nations as haunting forests, mountains, cataracts, rivers, and all unfrequented places. They are the dryads, naiads, kelpis, elves, fairies, and so forth. The elementals are often mysterious, terrifying, and dangerous. They are the spirits invoked by the Rosicrucians and mediæval magicians, and also by some in the present day. They respond to pentagrams and other symbols, and it is dangerous even to name them at certain times and places. The most powerful of them are the salamanders, or firespirits. The ability of the elementals to produce physical phenomena, and their lack of any moral sense, render them dangerous. In this they differ from the celestial spirits, for to these no physical demonstration is possible, as they do not come into contact with Matter.

35. The marvels of the adept are performed chiefly through the agency of the elementals. And it was the knowledge of and belief in them, on the part of the cen- 
turion in the Gospels, that elicited from Jesus his expression of surprise, "I have not found such faith even in Israel." For the centurion's reply had indicated his recognition of the fact that, just as he himself had soldiers under him to do his bidding, so Jesus had spirits under him. Others than adepts may be, and are, thus associated with the elementals; but only for one who, like an adept, has first purified and perfected himself in mind and spirit, is the association free from danger to himself or to others. Where not mastered, they become masters, and exact absolute subservience, showing themselves pitiless in the infliction of vengeance for disobedience to their behests.

36. To this order and sphere belong the class called by the Hebrews cherubim. They inhabit the "upper astral" immediately outside and below the celestial; and are the "covering angels," who encompass and guard the sanctuary of the innermost of man's system, the "holy of holies" of his own soul and spirit. Passing, by their permission, within the sacred precincts, we enter the presence of the celestials, of whom now we will speak.

\section{PART III.}

37. But first, in order the better to comprehend the procession of Spirit, it should be explained that Life may be represented by a triangle, at the apex of which is God. Of this triangle the two sides are formed by two streams, the one flowing outwards, the other upwards. The base may be taken to represent the material plane. Thus, from God proceed the Gods, the Elohim, or divine powers, who are the active agents of creation. From the Gods proceed all the hierarchy of heaven, with the various orders from the highest to the lowest. And the lowest are the orders of 
the genii, or guardian angels. These rest on the astral plane, but do not enter it. The other side of the triangle is a continuation of the base. And herein is the significance alike of the pyramid and of the obelisk. The pyramid represents the triangle of Life, fourfold, and resting on the earth. The obelisk, the summit only of which is pyramidal, represents a continuation of the base, and is covered with sculptured forms of animal life. For, of this base of the triangle of life, the continuation contains the lowest expressions of life, the first expressions of incarnation, and of the stream which, unlike the first, flows inwards and upwards. The side of the triangle represented by this stream, culminates in the Christ, and empties itself into pure Spirit, which is God. There are, consequently, spirits which by their natures never have been and never can be incarnate; and there are others which reach their perfection through incarnation. And the genii, dæmons, or guardian angels, have nothing in common with the astrals, but are altogether different and superior in kind. Standing, as they do, within the celestial sphere, their function is to lift man from below to their own high region, which, properly, is also his.

38. The day and night of the Microcosm, man, are its projective and reflective states. In the projective state we seek actively outwards; we aspire and will forcibly; we hold active communion with the God without.

39. In the reflective state we look inwards, we commune with our own heart; we indraw and concentrate ourselves secretly and interiorly. During this condition the "Moon" enlightens our hidden chamber with her torch, and shows us ourselves in our interior recess.

40. Who or what, then, is this Moon? It is part of ourselves, and revolves with us. It is our celestial affinity, - of 
whose order it is said, "Their angels do always behold the face of My Father."

4I. Every human soul has a celestial affinity, which is part of his system and a type of his spiritual nature. This angelic counterpart is the bond of union between the man and God; and it is in virtue of his spiritual nature that this angel is attached to him. Rudimentary creatures have no celestial affinity; but from the moment that the soul quickens, the cord of union is established.

42. The Genius of a man is this satellite. Man is a planet. God-the God of the man-is its sun. And the moon of this planet is Isis, its initiator, angel, or genius. The genius ministers to the man, and gives him light. But the light he gives is from God, and not of himself. $\mathrm{He}$ is not a planet, but a moon; and his function is to light up the dark places of his planet.

43. It is in virtue of man's being a planet that he has a moon. If he were not fourfold, as is the planet, he could not have one. Rudimentary men are not fourfold. They have not the Spirit.

44. Every human spirit-soul has attached to him a genius, variously called, by Socrates, a dæmon ; by Jesus, an angel; by the apostles, a ministering spirit. All these are but different names for the same thing.

45. The genius is linked to his client by a bond of soulsubstance. Persistent ill-living weakens this bond; and after several incarnations-even to the mystical seventy times seven - thus ill-spent, the genius is freed, and the soul definitively lost.

46. The genius knows well only the things relating to the person to whom he ministers. About other things he has opinions only. The relation of the ministering spirit to his client, is very well represented by that of the Catholic 
confessor to his penitent. $\mathrm{He}$ is bound to keep towards every penitent profound secrecy as regards the affairs of other souls. If this were not the case, there would be no order, and no secret would be safe. The genius of each one knows about another person only so much as that other's genius chooses to reveal.

47. The genius is the moon to the planet man, reflecting to him the sun, or God, within him. For the divine Spirit which animates and eternises the man, is the God of the man, the sun that enlightens him. And this sun it is, and not the outer and planetary man, that his genius, as satellite, reflects to him. Thus attached to the planet, the genius is the complement of the man; and his "sex" is always the converse of the planet's. And because he reflects, not the planet, but the sun, not the man (as do the astrals), but the God, his light is always to be trusted.

48. The genius never "controls" his client, never suffers the soul to step aside from the body to allow the entrance of another spirit. The person "controlled" by an astral or elementary, on the contrary, speaks not in his own person, but in that of the spirit operating. And the gestures, expression, intonation, and pitch of voice, change with the obsessing spirit. A person prophesying speaks always in the first person, and says, either, "Thus saith the Lord," or, "So says some one else," never losing his own personality.

49. The genii are not fighting spirits, and cannot prevent evils. They were allowed to minister to Jesus only after his exhaustion in combat with the lower spirits. Only they are attacked by these, who are worth attacking. No man ever got to the promised land without going through the desert. The best weapon against them is prayer. Prayer means the intense direction of the will and desire towards 
the Highest, an unchanging intent to know nothing but the Highest. So long as Moses held his hands up towards heaven, the Israelites prevailed; when he dropped them, then the Amalekites.

50. Now, there are two kinds of memory, the memory of the organism and the memory of the soul. The first is possessed by all creatures. The second, which is obtained by Recovery, belongs to the fully regenerate man. For the Divine Spirit of a man is not one with his soul until regeneration, which is the intimate union constituting what, mystically, is called the "marriage" of the hierophant, an event in the life of the initiate, one of the stages of which is set forth in the parable of the Marriage in Cana of Galilee.

$5 \mathrm{I}$. When this union takes place, there is no longer need of an initiator; for then the office of the genius is ended. For, as the moon, or Isis, of the planet man, the genius reflects to the Soul the Divine Spirit, with which she is not yet fully united. In all things is order. Wherefore, as with the planets, so with the Microcosm. They who are nearest Divinity, need no moon. But so long as they have night,-so long, that is, as any part of the soul remains unilluminated, and her memory or perception obscure,-so long the mirror of the angel continues to reflect the sun to the soul.

$52 .{ }^{4}$ For the memory of the soul is recovered by a threefold operation - that of the soul herself, of the moon, and of the sun. The genius is not an informing spirit. He can tell nothing to the soul. All that she receives is already hers. But in the darkness of the night, it would remain

- Paragraphs 52 to $5^{8}$ were received by Anna Kingsford in sleep on the 2Sth May, 1881, "while she was writing the lecture on the Atonement" (Life of $A$. $K$., vol. ii., pp. 12-14; C.W.S., part i., No. xiv., p. 64). 
undiscovered, but for the torch of the angel who enlightens. "Yea," says the angel genius to his client, "I illuminate thee, but I instruct thee not. I warn thee, but I fight not. I attend, but I lead not. Thy treasure is within thyself. My light showeth where it lieth." 5

53. When regeneration is fully attained, the divine Spirit alone instructs the hierophant. "For the gates of his city shall never be shut; there shall be no night there; the night shall be no more. And they shall not need the light of the lamp, because the Lord God shall enlighten them." The prophet is a man illumined by his angel. The Christ is a man married to the Spirit. And he returns out of pure love to redeem, needing no more to return to the flesh for his own sake. Wherefore he is said to come down from heaven. For he has attained, and is a Medium for the Highest. He baptises with the Holy Ghost, and with the Divine Fire itself. $\mathrm{He}$ is always " in Heaven." And in that he ascends, it is because the Spirit uplifts him, even the Spirit who descends upon him. "And in that he descends, it is because he has first ascended beyond all spheres into the highest Presence. For he that ascends, ascends because he also descended first into the lower parts of the earth. He that descended is the same also who ascended above all the heavens, to fill all things." Such a one returns, therefore, from a higher world; he belongs no more to the domain of Earth. But he comes from the sun itself, or from some nearer sphere to the sun than ours, having passed from the lowest upwards.

54. And what, it will be asked, of the genius himself? Is he sorry when his client attains Perfection, and needs him no more?

${ }^{5}$ Respecting the complete, final recovery of memory, see C.W.S., part i., No. xl., p. 156. 
" He that hath the bride is the bridegroom. And he that standeth by rejoiceth greatly because of the bridegroom's voice." The genius, therefore, returns to his source, for his mission is ended, and his Sabbath is come. $\mathrm{He}$ is one with the Twain.

55. The genius, then, remains with his client so long as the man is fourfold. A beast has no genius. A Christ has none. For first, all is latent light. That is one. And this one becomes two; that is, body and astral body. And these two become three; that is, a rational soul is born in the midst of the astral body. This rational soul is the person; itself dual, in virtue of its earthly and its divine parts. And from that moment this personality is an individual existence, as a plant or as an animal. These three become four; that is, human. And the fourth is the Nous, not yet one with the soul, but overshadowing it, and transmitting light as it were through a glass, that is, through the initiator. But when the four become three,-that is, when the "nıarriage" takes place, and the soul and the spirit are indissolubly united,-there is no longer need either of migration or of genius. For the Nous has become one with the soul, and the cord of union is dissolved. And yet again, the three become twain at the dissolution of the body; and again, the twain become one, that is, the Christ-spirit-soul. " The Divine Spirit and the genius, therefore, are not to be regarded as diverse, nor yet as identical. The genius is flame, and is celestial ; that is, he is Spirit, and one in nature with the Divine; for his light is the Divine Light. $\mathrm{He}$ is as a glass, as a cord, as a bond between the soul and her divine part. He is the clear atmosphere through which the divine ray passes, making a path for it in the astral medium.

56. In the celestial plane, all things are personal. And therefore the bond between the soul and spirit is a person. 
But when a man is what is mystically called "born again," he no longer needs the bond which unites him to his Divine Source. The genius, or flame, therefore, returns to that Source; and this being itself united to the soul, the genius also becomes one with the Twain. For the genius is the Divine Light in the sense that he is but a divided tongue of it, having no isolating vehicle. But the tincture of this flame differs according to the celestial atmosphere of the particular soul. The Divine Light, indeed, is white, being Seven in One. But the genius is a flame of a single colour only. And this colour he takes from the soul, and by that ray transmits to her the light of the Nous, her Divine Spouse. The angel-genii are of all the tinctures of all the colours.

57. While in the celestial plane all things are persons, in the astral plane they are reflects, or at most impersonal. The genius is a person because he is a celestial, and of soulspirit, or substantial nature. But the astrals are of fluidic nature, having no personal part. In the celestial plane, spirit and substance are one, dual in unity; and thus are all celestials constituted. But in the astral plane they have no individual, and no divine part. They are protoplasmic only, without either nucleus or nucleolus.

58. The voice of the angel-genius is the voice of God; for God speaks through him as a man through the horn of a trumpet. He may not be adored; for he is the instrument of God, and man's minister. But he must be obeyed; for he has no voice of his own, but shows the will of the Spirit.

59. They, therefore, who desire the Highest, will not seek to "controls"; but will keep their temple-which is their body-for the Lord God of Hosts; and will turn out of it the money-changers and the dove-sellers and the 
dealers in curious arts, yea, with a scourge of cords, if need be.

60. Of the superior orders in the celestial hierarchy-of those, that is, who, being Gods and Archangels, are to the Supreme Spirit as the seven rays of the prism are to light, and the seven notes of the scale are to sound-the knowledge appertains to the Greater Mysteries, and is reserved for those who have fulfilled the conditions requisite for initiation therein. Of those conditions the first is the complete renunciation of a diet of flesh, the reason being fourfold, - spiritual, moral, intellectual, and physical, - according to the fourfold constitution of man. This is imperative. Man cannot receive, the Gods will not impart, the mysteries of the Kingdom of Heaven on other terms. The conditions are God's ; the will is with man. ${ }^{6}$

- See C.W.S., part i., No. ii., pp. 5-8. 


\section{LECTURE THE FOURTH. ${ }^{1}$}

\section{THE ATONEMENT.}

\section{PART I.}

I. WE have chosen to speak thus early in our series of the doctrine of the Atonement, because it is that around which all religious teaching, ancient and modern, pure and corrupt, is alike grouped, and in which it all centres. Constituting thus the pivot and point of radiation of Religion itself, this doctrine, expounded in its pure and ancient sense, is at once the glory of the saint and the hope of the fallen ; expounded in its modern and corrupt sense, it is to the latter a licence, and to the former a shame and perplexity.

2. As will by and by be fully shown, sacred Mysteries are, like all things kosmic, fourfold, in that they contain, like the whorls of a flower, or the elements of an organic cell, four mutually related and yet distinct Modes and Ideas. And these four are-from without inwards-the Physical, the Intellectual, the Ethical, and the Spiritual. We propose in this lecture to explain the doctrine of the Atonement from each of these points of view, in order to do which with clearness and without fear of misapprehension, we shall first expose the common errors in regard to it.

1 This lecture was written by Anna Kingsford, entirely, Edward Maitland's part in it being little more than that of literary revision; and was delivered by her on Monday the $13^{\text {th June, }}$ 188I ( Life of $A$. $K$., vol. ii., pp. 16, 17, 32). 
3. The popular and corrupt view of the doctrine of the Atonement presents us with one of the most salient examples extant of that materialism in things religious, which constitutes Idolatry. To commit the sin of Idolatry is to materialise spiritual Truth, by concealing under gross images the real substantial Ideas implied, and setting up the images for worship in place of the celestial verities. Now, the current doctrine of Christ's Atonement starts with the irrational, and therefore false, hypothesis, that between physical blood and moral guilt there is a direct and congruous relation, in virtue of which the opening of veins and laceration of muscular tissue constitute a medium of exchange by which may be ransomed an indefinite number of otherwise forfeited souls.

4. In opposition to this and other kindred conceptions, it is necessary to insist on the principle which, being, so to speak, the corner-stone and centre of gravitation of Religion, was in our Introductory Lecture prominently placed before the reader,- the principle that sacred Mysteries relate only to the Soul, and have no concern with phenomena or any physical appearances or transactions. The key-note of Religion is sounded in the words, "My kingdom is not of this world." All her mysteries, all her oracles, are conceived in this spirit, and similarly are all sacred scriptures to be interpreted. For anything in Religion to be true and strong, it must be true and strong for the Soul. The Soul is the true and only person concerned; and any relation which Religion may have to the body or phenomenal man, is indirect, and by correspondence only. It is for the Soul that the Divine Word is written ; and it is her nature, her history, her functions, her conflicts, her redemption, which are ever the theme of sacred narrative, prophecy, and doctrine.

5. But a priesthood fallen from the apprehension of 
spiritual things, and only competent, therefore, to discern the things of sense,-a priesthood become, in a word, idolatrous, - is necessarily incapable of attaining to the level of the original framers of the Mysteries appertaining to the Soul; and therefore it is that invariably in the hands of such priesthood, the Soul has been ignored in favour of the body, and a signification grossly materialistic substituted for that which had been addressed only to the spiritual man.

6. To the thoughtful mind there is nothing more perplexing than the doctrine and practice of bloody sacrifice, commonly believed to be inculcated in that portion of the Hebrew scriptures which is known as the Pentateuch. And the perplexity is increased by a comparison of this with the prophetical books in which occur such utterances as the following :-

"Sacrifice and oblation Thou dost not desire: but Thou hast opened ears for me.

"Burnt-offering and sin-offering Thou wouldest not; but that I should come to do Thy Will.

"The sacrifices of God are a broken spirit, a lowly and contrite heart, O God."

And, yet more emphatically and indignantly, the prophet Isaias :-

"Hear the word of the Lord, ye rulers of Sodom; give ear to the law of our God, ye people of Gomorrha.

"To what purpose do you offer me the multitude of your victims? saith the Lord. I desire not holocausts of rams and fatlings, the blood of calves, and sheep, and goats.

"When you come to appear before Me, who hath required these things at your hands?

"Offer sacrifice no more; your new moons and festivals I cannot abide; your assemblies are wicked.

"My soul hateth your solemnities; when you stretch forth 
your hands I turn away Mine eyes, for your hands are full of blood."

And again, in Jeremias :-

"I, the Lord, spake not to your fathers, and I commanded them not in the day that $I$ brought them out of the land of Egypt, concerning the inatter of burnt-offerings and sacrifices.

"But this one thing I commanded them, saying, Hearken to $\mathrm{My}$ voice, and walk in My way.

"But they have set their abominations in the house that is called by My Name, to pollute it."

7. In the presence of these truly Divine words, what must be our verdict upon certain contrary declarations and prescriptions in the Pentateuch? We must say, as indeed all sound criticism and inference based on careful examination of internal evidence justify us in saying, that the greater part of the Five Books, and especially the chapters prescriptive of ritual and oblations, are of far later date than that usually assigned to them, and are not in any sense the work of the inspired Moses, or of his initiates and immediate successors, but of a corrupted priesthood, in the age of the kings - a priesthood greedy of gifts, tithes, and perquisites; ever replacing the spirit by the letter, and the idea by the symbol; ignorant of the nature of Man, and therefore ever trampling under foot his true and better self, the Soul, whose type is Woman; "taking away the key of knowledge, entering not themselves into the Kingdom, and hindering those who would have entered." But for these bloody and idolatrous sacrifices, there would have been neither occupation nor maintenance for the numerous ecclesiastics who subsisted by means of them ; and but for the false and corrupt conception of a God whose just anger was capable of being appeased by slaughter, - and this of the innocent,- 
and whose favour could be bought by material gifts, the whole colossal scheme of ceremonial rites and incantations which gave the priesthood power and dominion over the people, would never have found place in a system originally addressed wholly to the needs of the soul. ${ }^{2}$

Thus, even with the Old Testament alone as evidence, our verdict must be given to the Prophet as against the Priest, seeing that while the former, as the true Man of God, directed his appeal to the soul, the latter, as the minister of sense, cared only to exalt his own Order, no matter at what cost to the principles of religion.

8. Turning to the New Testament, a significant fact confronts us. It is, that Jesus appears never to have sanctioned by his presence any of the Temple services; an abstention which cannot but be regarded as a tacit protest against the sacrificial rites then in vogue. Nor in all the utterances ascribed to him is there any reference to these rites even in connection with the common belief that they were designed as types of the death supposed to be ordained for the Messiah in his character of Redeemer and Victim.

9. And truly, it is inconceivable that if the special object and end of his incarnation had been, as is currently held, to be immolated on the Cross, a spotless sin-offering for men, in propitiation of the wrath of God against the guilty, no word implying a doctrine so essential and tremendous should have been uttered by the Divine Victim himself, or that it should have been left to later statements of uncertain authorship and interpretation, and chiefly to men who never were disciples of Jesus-Paul and Apollos-to formulate and expound it. Nor can we regard as other than fatuous the conduct of a priesthood, which, while throwing upon the Cross of Calvary the burden of the salvation of the ${ }^{2}$ See C.W.S., part i., No. v., pp. $20-22$. 
whole world in all ages, and teaching mankind that to the innocent sacrifice thereon offered is alone due their rescue from eternal damnation, yet sees fit to execrate and brand with infamy the very men who procured the consummation of that sacrifice,-and to whom, therefore, next to Jesus himself, the world is indebted for ransom from hell, and for the opening of the gates of heaven,-Caiaphas, Pontius Pilate, and-most important of all-Judas the traitor!

ro. The truth is, that so far from depicting Priest and Prophet as co-operating for the welfare of man, the sacred scriptures exhibit them in constant conflict; - the Priest, as the minister of Sense, perpetually undoing the work performed by the Prophet as the minister of the Intuition. And so it is seen that when, at length, the greatest of all the prophetical race appears, the priesthood does not fail to compass his death also, and subsequently to exalt the crime into a sacrifice, and that of such a nature as to render it the apotheosis of the whole sacerdotal system, and to advance the sacerdotal order to the position which, throughout Christendom, it has ever since maintained !

\section{PART II.}

II. At this point another aspect of our subject claims attention. It relates, not to any particular sacrifice, but to the whole question of the origin and nature of bloody sacrifices generally. And it involves reference to influences and motives yet darker and more potent than any mere human desire of gain or power, in exposing which it will be necessary to speak of occult subjects, unfamiliar save to those who, being acquainted with the science of magic, understand at least something of the nature and conditions of "spiritual" apparitions.

12. The effusion of physical blood has, in all ages, been 
a means whereby magicians have evoked astral phantoms or phantasmagoric reflects in the magnetic light. These efflorescences of the lower atmosphere immediately related to the body, have a direct affinity for the essential element, called by the old physiologists the "vital spirits," of the blood, and are enabled by means of its effusion to manifest themselves materially. Thus, as one recent writer says, "Blood begets phantoms, and its emanations furnish certain spirits with the materials requisite to fashion their temporary appearances." 3 Another speaks of blood as "the first incarnation of the universal fluid, materialised vital light, the arcanum of physical life." " The famous Paracelsus also asserts that by the fumes of blood one is able to call forth any spirit desired, for by its emanations the spirit can build for itself a visible body. This, he says, is Sorcery, a term always of ill-repute. The hierophants of Baal made incisions all over their bodies, in order to produce visible objective phantoms. There are sects in the East, especially in Persia, whose devotees celebrate religious orgies in which, whirling frantically round in a ring, they wound themselves and each other with knives, until their garments and the ground are soaked with blood. Before the end of the orgy, every man has evoked a spectral companion which whirls round with him, and which may sometimes be distinguished from the devotee by having hair on its head, the devotees being closely shorn. The Yakuts of Eastern Siberia still maintain the practice of the once famed witches of Thessaly, offering nocturnal sacrifices and evoking evil spectres to work mischief for them. Without the fumes of blood these beings could not become visible; and were they deprived of it, they would, the Yakuts believe, suck 
it from the veins of the living. It is further held by these people that good spirits do not thus manifest themselves to view, but merely make their presence felt, and require no preparatory ceremonial. The Yezidis, inhabiting Armenia and Syria, hold intercourse with certain aërial spirits which they call Jakshas, - probably mere astral phantoms, and evoke them by means of whirling dances, accompanied, as in the case of the sect already mentioned, by selfinflicted wounds. Among the manifestations thus obtained is the apparition of enormous globes of fire, which gradually assume grotesque and uncouth animal forms. ${ }^{5}$

13. Reverting to earlier times, we find in the writings of Epiphanius, a passage concerning the death of Zacharias, which bears directly on the Levitical practice in regard to this subject. He says that Zacharias, having seen a vision in the Temple, and being, through surprise, about to disclose it, was suddenly and mysteriously deprived of the power of speech. He had seen at the time of offering incense after the evening sacrifice, a figure in the form of an ass, standing by the altar. Going out to the people, he exclaimed,- "Woe unto you / whom do ye worship?" and immediately "he who had appeared to him in the Temple struck him with dumbness." Afterwards, however, he recovered his speech and related the vision, in consequence of which indiscretion the priests slew him. It was asserted by the Gnostics that the use of the little bells attached to the garments of the high-priest was enjoined by the Jewish ordinance-makers with special reference to these apparitions, in order that on his entry into the sanctuary at the time of sacrifice, the goblins might have warning of his approach in time to avoid being caught in their natural hideous shapes.

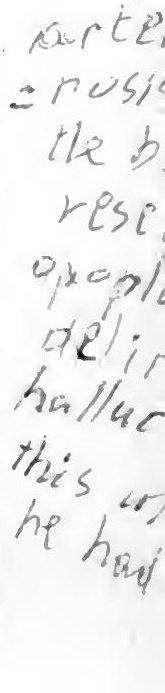

s Lady Hester Stanhope. 
14. An experience of the writer's received ${ }^{6}$ while preparing this lecture well illustrates the foregoing citations. Conducted in magnetic sleep by her guardian Genius into a large hall of temple-like structure, she beheld a number of persons grouped in adoration around four altars upon which were laid as many slaughtered bullocks. And above the altars, in the fume of the spirits of the blood arising from the slain beasts, were misty colossal figures, half-formed only, from the waist upwards, and resembling the Gods. One of them in particular attracted the writer's attention. It was the head and bust of a woman of enormous proportions and wearing the insignia of Diana. And the Genius said: "These are the Astral Spirits, and thus will they do until the end of the world."

Such were the spurious phantom-images, which, with emaciated forms and pallid countenances, presented themselves to the Emperor Julian, and, claiming to be the veritable Immortals, commanded him to renew the sacrifices, for the fumes of which, since the establishment of Christianity, they had been pining. And he, able only to see, but not to discern, spirits, took these spectres-as so many still do-for what they pretended to be, and, seeking to fulfil their behests, earned for himself the title of "Apostate." To the impulsion of spirits of this order are to be ascribed those horrible human sacrifices of which in ancient times Canaan was the chief scene and Moloch the chief recipient. In these sacrifices the Jews themselves largely indulged, the crowning example being that of which the high priest Caiaphas was the prompter.

15. But idolatry and bloody sacrifice have ever been held in abhorrence by the true prophet and the true redeemer.

${ }^{6}$ Received on the 28th May, $188 \mathrm{I}$, by Anna Kingsford in sleep ( $L$ ife of $A . K$., vol. ii., pp. 13, 14 ; C.W.S., part i., No. xiv., at p. 66). 
The aspect under which these things present themselves to the eyes of such men is epitomised in the divine and beautiful rebuke addressed by Gautama Buddha to the priests of his day, for an exquisite rendering of which the reader is referred to Sir Edwin Arnold's recent poem, "The Light of Asia." 7 Buddha, it will be observed, classed with the practice of bloody sacrifice the habit of flesheating, and included both in his unsparing denunciation. The reason is not far to seek. Man, as the Microcosm, resembles in all things the Macrocosm, and like the latter, therefore, he comprises within his own system an astral plane or circulus. In eating flesh, and thereby ingesting the blood principle,-flesh and blood being inseparable,-he sacrifices to the astral emanations of his own magnetic atmosphere, and so doing, ministers to the terrene and corruptible. This it is to "eat of things offered to idols," for blood is the food of the astral eidola, and the eater of blood is infested by them.

16. It should be observed that this astral medium and its emanations are incapable of originating ideas, for these are positive entities and come from the celestial or spiritual "heaven." The astral, being reflective merely and unsubstantial, receives divine ideas but to reverse and travesty them. Thus, the doctrine of sacrifice and of atonement are true doctrines, and of celestial origin; but the sacrifice must be of the lower human self to the higher divine self, and of personal extraneous affections to the love of God and of principles. But the astral mind, reversing the truth, converts these aspirations into the sacrifice of the higher to the lower nature, of the soul to the body, and of others to oneself. Again, the truth that man is saved by the

7 P. $139,1.22$. The appearance of this remarkable book constitutes a sign of the times of no small importance. 
perpetual sacrifice of God's own Life and Spirit to be his life and spirit, finds a like distortion in the notion that man is saved by taking the life of a God and appropriating his merits. The true meaning of the word "atonement" is reconciliation, rather than "propitiation." For "Heaven" cannot be "propitiated" save by at-one-ment.

I7. As, moreover, the astral and the physical planes are intimately united, and both are ephemeral and evanescent, of Time and of Matter, that which feeds and ministers to the astral stimulates the physical, to its own detriment and that of the inner and permanent Twain,-soul and spirit, the true man and his Divine Particle,_-since these, being celestial, have neither part nor communion with the merely phenomenal and phantasmal. For the astral emanations resemble clouds which occupy the earthy atmosphere between us and heaven, and which, filmy and incorporeal though they be, are nevertheless material, and are born of the exhalations of earth. To perpetuate and do sacrifice to these phantoms, is to thicken the atmosphere, to obscure the sky, to gather fog and darkness and tempest about us, as did the old storm-witches of the North.

Such is that worship which is spoken of as the worship of the Serpent of the Dust; and thus does he who ingests blood; for he makes thereby oblation to the infernal gods of his own system, as does the sacrificing priest to the powers of the same sphere of the Macrocosm.

I8. And this occult reason for abstaining from the ingestion of flesh, is that which in all ages and under all creeds has ever powerfully and universally influenced the Recluse, the Saint, and the Adept in Religion. As is well known, the use of flesh was in former times invariably abjured by the hermit-fathers, by the ascetics of both East and West, and in short by all religious persons, male and female, who, 
aspiring after complete detachment from the things of sense, sought interior vision and intimate union with the Divine; and it is now similarly abjured by the higher devotional orders of the Catholic Church and of Oriental adepts.

Let us say boldly, and without fear of contradiction from those who really knozv, that the Interior Life and the clear Heaven are not attainable by men who are partakers of blood;-men whose mental atmosphere is thick with the fumes of daily sacrifices to idols. For so long as these shadows infest the Man, obscuring the expanse of the higher and divine Ether beyond, he remains unable to detach himself from the love for Matter and from the attractions of Sense, and can at best but dimly discern the Light of the Spiritual Sun.

19. Abstinence from bloody oblations on all planes is therefore the gate of the Perfect Way, the test of illumination, the touchstone and criterion of sincere desire for the fulness of Beatific Vision.

The Holy Grail, the New Wine of God's Kingdom, of which all souls must drink if they would live for ever, and in whose cleansing tide their garments must be made white, is, most assuredly, not that plasmic humour of the physical body, common to all grades of matcrial life, which is known to us under the name of blood. But, as this physical humour is the life of the phenomenal body, so is the blood of Christ the Life of the Soul, and it is in this interior sense, which is alone related to the Soul, that the word is used by those who framed the expression of the Mysteries.

PART III.

20. This brings us to speak of what the Atonement is, and of the sense in which we are to understand it, in its fourfold interpretation. 
First, let us remind the reader, the Cross and the Crucified are symbols which come down to us from pre-historic ages, and are to be found depicted on the ruined monuments, temples, and sarcophagi of all nations, Coptic, Ethiopian, Hinda, Mexican, Tartar. In the rites of all these peoples, and especially in the ceremonials of initiation held in the Lodges of their Mysteries, the Cross had a prominent place. It was traced on the forehead of the neophyte with water or oil, as now in Catholic Baptism and Confirmation; it was broidered on the sacred vestments, and carried in the hand of the officiating hierophant, as may be seen in all the Egyptian religious tablets. And this symbolism has been adopted by and incorporated into the Christian theosophy, not, however, through a tradition merely imitative, but because the Crucifixion is an essential element in the career of the Christ. For, as says the Master, expounding the secret of Messiahship, "Ought not the Christ to suffer these things, and so to enter into his glory?" Yes, for this Cross of Christ-the spiritual Phoibos-is made by the sun's equinoctial passage across the line of the Ecliptic, - a passage which points on the one hand to the descent into Hades, and on the other to the ascent into the kingdom of Zeus the Father. It is the Tree of Life; the Mystery of the Dual Nature, male and female; the Symbol of Humanity perfected, and of the Apotheosis of Suffering. It is traced by "Our Lord the Sun" on the plane of the heavens; it is represented by the magnetic and diamagnetic forces of the earth; it is seen in the icecrystal and in the snow-flake; the human form itself is modelled upon its pattern; and all nature bears throughout her manifold spheres the impress of this sign, at once the prophecy and the instrument of her redemption.

2r. Fourfold in meaning, having four points, and making

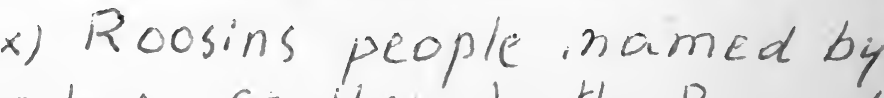


four angles, dividing the circle into four equal parts, the cross pourtrays the perfect union, balance, equality, and at-one-ment on all four planes and in all four worlds-phenomenal, intellectual, psychic, and celestial - of the Man and the Woman, the Spirit and the Bride. It is supremely, transcendently, and excellently, the symbol of the Divine Marriage; that is, the Sign of the Son of Man In Heaven. For the Divine Marriage is consummated only when the Regenerate Man enters the Kingdom of the celestial, which is within. Then the Without is as the Within, and the Twain are as One in Christ Jesus.

22. Being thus the key of all the worlds, from the outer to the inner, the Cross presents, as it were, four wards or significations; and according to these, the mystery of the Crucifixion bears relation :-

First, to the natural and actual sense, and typifies the Crucifixion of the Man of God by the world.

Secondly, to the intellectual and philosophical sense, and typifies the Crucifixion in man of the lower nature.

Thirdly, to the personal and sacrificial sense, and symbolises the Passion and Oblation of the Redeemer.

Fourthly, to the celestial and creative sense, and represents the Oblation of God for the Universe.

23. First in order, from without inwards, the Crucifixion of the Man of God implies that persistent attitude of scorn, distrust, and menace with which the Ideal and Substantial is always met by the worldly and superficial, and to the malignant expression of which ill-will the Idealist is always exposed. We have noted that Isaias, rebuking the materialists for their impure and cruel rites, addresses them as "rulers of Sodom and people of Gomorrah." So likewise, the Seer of the Apocalypse speaks of the two divine Witnesses as slain "in the streets of the great city, which 
is called spiritually Sodom and Egypt, where also the Lord was crucified." This city, then, is the world, the materialising, the idolatrous, the blind, the sensual, the unreal; the house of bondage, out of which the sons of God are called. And the world being all these, is cruel as hell, and will always crucify the Christ and the Christ-Idea. For the world, which walks in a vain shadow, can have no part in the kingdom of heaven; the man who seeks the Within and the Beyond is to it a dotard, a fool, an impostor, a blasphemer, or a madman; and according to the sense of its verdict, it ridicules, maligns, despoils, punishes, or sequesters him. And thus every great and merciful deed, every noble life, every grand and holy name, is stamped with the hall-mark of the Cross.

Scorn and contumely and the cries of an angry crowd surround that altar on which the Son of God makes oblation of himself; and cross after cross strews the long Via Dolorosa of the narrow path that leadeth unto Life.

For indeed the world is blind, and every redemption must be purchased by blood.

24. Yes, by blood and tears and suffering, and these not of the body only; for the Son of God, to attain that Sonship, must have first crucified in himself the old Adam of the earth. This is the second meaning of the Cross; it sets forth that interior process of pain which precedes regeneration; that combat with and victory over the tempter, through which all the Christs alike have passed; the throes of travail which usher in the New-Born. And the crucified, regenerate Man, having made At-one-ment throughout his own fourfold nature, and with the Father through Christ, bears about in himself the "marks" of the Lord,-the five wounds of the five senses overcome, the "stigmata" of the saints. This crucifixion is the death of the body; the 
rending of the veil of the flesh; the uniting of the human will with the Divine will ; or, as it is sometimes called, the Reconciliation - which is but another word for the At-onement. It is the consummation of the prayer, "Let Thy Will be done on earth as it is in Heaven;" let Thy Will, $\mathrm{O}$ Father, be accomplished throughout the terrene and astral, even as it is in the inmost adytum, that in all the microcosmic system no Will be found other than the Divine.

25. This also is the secret of transmutation,- the changing of the water into wine, of Matter into Spirit, of man into God. For this blood of Christ and of the Covenant-this wine within the holy Chalice, of which all must drink who nevermore would thirst-is the Divine Life, the vital immortal principle, having neither beginning nor end, the perfect, pure, and incorruptible Spirit, cleansing and making white the vesture of the soul as no earthly purge can whiten; the gift of God through Christ, and the heritage of the elect. To live the Divine Life is to be partaker in the blood of Christ and to drink of Christ's cup. It is to know the love of Christ which "passeth understanding," the love which is Life, or God, and whose characteristic symbol is the blood-red ray of the solar prism. By this mystical blood we are saved,--this blood, which is no other than the secret of the Christs, whereby man is transmuted from the material to the spiritual plane, the secret of inward purification by means of Love. For this " blood," which, throughout the sacred writings is spoken of as the essential principle of the "Life," is the spiritual Blood of the spiritual Life,Life in its highest, intensest, and most excellent sense, - not the mere physical life understood by materialists, - but the very substantial Being, the inward Deity in man. And it is by means of this Blood of Christ only-that is by means of Divine Love only - that we can "come to the Father," and 
inherit the kingdom of heaven. For, when it is said that "the blood of Christ cleanseth from all sin," it is signified that $\sin$ is impossible to him who is perfect in Love.

26. But the Christ is not only the type of the sinless Man, the hierarch of the mysteries; he is also the Redeemer. Now, therefore, we come to speak of the Vicarious and Redemptive office of the Divine Man, of his Passion, Sacrifice, and Oblation for others.

There is a true and there is a false rendering of this Mystery of Redemption, which is the central mystery of the Divine Life, the Gold of the target, the heart of Jesus, the bond of all grace, the very core and focus and crown of Love.

This third aspect of the Cross is in itself two-fold, because Wisdom and Love, though one in essence, are twain in application, since Love cannot give without receiving, nor receive without giving. We have therefore in this double mystery both the oblation and lifting up of the Christ in Man, and the Passion and Sacrifice for others of the Man in whom Christ is manifest. For even as Christ is one in us, so are we one with Christ, because, as Christ loves and gives himself for us, we also who are in Christ give ourselves for others.

27. But the notion that man requires, and can be redeemed only by, a personal Saviour in the flesh, extraneous to himself, is an idolatrous travesty of the truth. For that whereby a man is "saved" is his own re-birth and At-onement in a sense transcending the phenomenal. And this process is altogether interior to the man, and incapable of being performed from without or by another; a process requiring to be enacted anew in each individual, and impossible of fulfilment by proxy in the person of another. True, the new spiritual Man thus born of Water and the 
Spirit, or of the Pure Heart and the Divine Life; the Man making oblation on the cross, overcoming Death and ascending to Heaven, is named Christ-Jesus, the Only Begotten, the Virgin-born, coming forth from God to seek and to save the lost; but this is no other than the description of the man himself after transmutation into the Divine Image. It is the picture of the regenerate man, made "alive in Christ," and "like unto him." For the Christos or Anointed, the Chrestos or Best, are but titles signifying Man Perfect; and the name of Jesus, at which every knee must bow, is the ancient and ever Divine Name of all the Sons of GodIesous or Yesha, he who shall save, and Issa the Illuminated, or Initiate of Isis. For this name Isis, originally IshIsh, was Egyptian for Light-Light ; that is, light doubled, the known and the knowing made one, and reflecting each other. It is the expression of the apostolic utterance, "Face to face, knowing as we are known, transformed into the image of His glory." Similarly our affirmatives is and yes; for in both Issa and Iesous "all the promises of God are Yes," because God is the supreme Affirmative and Positive of the universe, enlighteming every soul with truth and life and power. God is the Sun of the soul, whereof the physical sun is the hieroglyph, as the physical man is of the true eternal spiritual Man.

28. The light is positive, absolute, the sign of Being and of the everlasting "Yes"; and "the children of the Light" are they who have the gnosis and eternal Life thereby. But the negation of God is "Nay," the Night, the Destroyer and the devil. The name therefore of Antichrist is Denial, or Unbelief, the spirit of Materialism and of Death. And the children of darkness are they who have quenched in themselves the divine Love, and "know not whither they go, because darkness hath blinded their eyes." Hence 
the Serpent of the Dust is spoken of as "the Father of Lies," that is, of negations; for the word "lie" means nothing else than "denial." "No denial is of the truth," says S. John, "for this is Antichrist, even he that denieth. Every spirit which annulleth Jesus (or the divine Yes) is not of God. By this we know the spirit of Truth, and the spirit of Error."

29. Christ Jesus, then, is no other than the hidden and true man of the Spirit, the Perfect Humanity, the Express Image of the Divine Glory. And it is possible to man, by the renunciation-which mystically is the crucifixion-of his outer and lower self, to rise wholly into his inner and higher self, and, becoming suffused or anointed of the Spirit, to "put on Christ," propitiate God, and redeem the earthly and material.

30. And that which they who, in the outer manifestation, are emphatically called Christs, - whether of Palestine, of India, of Egypt, or of Persia,-have done for man, is but to teach him what man is able to be in himself by bearing, each for himself, that Cross of renunciation which they have borne. And inasmuch as these have ministered to the salvation of the world thereby, they are truly said to be saviours of souls, whose doctrine and love and example have redeemed men from death and made them heirs of eternal life. The Wisdom they attained, they kept not secret, but freely gave as they had freely received. And that which thus they gave was their own life, and they gave it knowing that the children of darkness would turn on them and rend them because of the gift. But, with the Christs, $W$ isdom and Love are one, and the testament of Life is written in the blood of the testator. Herein is the difference between the Christ and the mere adept in knowledge. The Christ gives and dies in giving, because Love constrains 
him and no fear withholds ; the adept is prudent, and keeps his treasure for himself alone. And as the At-one-ment accomplished in and by the Christs, is the result of the unreserved adoption of the Divine Life, and of the unreserved giving of the Love mystically called the Blood of Christ, those who adopt that Life according to their teaching, and who aspire to be one with God, are truly said to be saved by the Precious Blood of the Lamb slain from the foundation of the world. For the Lamb of God is the spiritual Sun in Aries, the spring-tide glory of ascending Light, the symbol of the Pure Heart and the Righteous Life, by which humanity is redeemed. And this Lamb is without spot, white as snow, because white is the sign of Affirmation and of the "Yes"; as black is of Negation and of the devil. It is Iesous Chrestos, the Perfect Yes of God, who is symbolised by this white Lamb, and who, like his sign in heaven, was lifted up on the Cross of Manifestation from the foundation of the world.

31. In the holy Mysteries, dealing with the process of that second and new creation, which-constituting a return from Matter to Spirit-is mystically called Redemption, every term employed refers to some process or thing subsisting or occurring within the individual himself. For, as man is a Microcosm, and comprises within all that is without, the processes of Creation by Evolution, and of Redemption by Involution, occur in the Man as in the Universe, and thereby in the Personal as in the General, in the One as in the Many. With the current orthodox symbolism of man's spiritual history, the Initiate, or true Spiritualist, has no quarrel. That from which he seeks to be saved is truly the Devil, who through the sin of the Adam has power over him; that whereby he is saved is the precious blood of the Christ, the Only-begotten, whose mother is the immaculate ever-virgin 
Maria. And that to which, by means of this divine oblation, he attains is the Kingdom of Heaven and eternal Life. But, with the current orthodox interpretation of these terms, the Initiate is altogether at variance. For he knows that all these processes and names refer to Ideas, which are actual and positive, not to physical transcripts, which are reflective and relative only. He knows that it is within his own microcosmic system he must look for the true Adam, for the real Tempter, and for the whole process of the Fall, the Exile, the Incarnation, the Passion, the Crucifixion, the Resurrection, the Ascension, and the Coming of the Holy Spirit. And any mode of interpretation which implies other than this, is not celestial but terrene, and due to that intrusion of earthly elements into things divine, that conversion of the inner into the outer, that "Fixing of the Volatile" or materialisation of the Spiritual, which constitutes idolatry.

32. For, such of us as know and live the inner life, are saved, not by any Cross on Calvary eighteen hundred years ago, not by any physical blood-shedding, not by any vicarious passion of tears and scourge and spear; but by the Christ-Jesus, the God with us, the Immanuel of the heart, born, working mighty works, and offering oblation in our own lives, in our own persons, redeeming us from the world, and making us sons of God and heirs of everlasting life.

33. But, if we are thus saved by the love of Christ, it is by love also that we manifest Christ to others. If we have received freely, we also give freely, shining in the midst of night, that is, in the darkness of the world. For so long as this darkness prevails over the earth, Love hangs on his cross; because the darkness is the working of a will at variance with the Divine Will, doing continual violence to the Law of Love. 
34. The wrongs of others wound the Son of God, and the stripes of others fall on his flesh.

$\mathrm{He}$ is smitten with the pains of all creatures, and his heart is pierced with their wounds.

There is no offence done and he suffers not, nor any wrong and he is not hurt thereby.

For his heart is in the breast of every creature, and his blood in the veins of all flesh.

For to know perfectly is to love perfectly, and so to love is to be partaker in the pain of the beloved.

And inasmuch as a man loves and succours and saves even the least of God's creatures, he ministers unto the Lord.

Christ is the perfect Lover, bearing the sorrows of all the poor and oppressed.

And the sin and injustice and ignorance of the World are the nails in his hands, and in his feet.

$O$ Passion of Love, that givest thyself freely, even unto deathI

For no man can do Love's perfect work unless Love thrust him through and through.

But, if he love perfectly, he shall be able to redeem; for strong Love is a Net which shall draw all souls unto him.

Because unto Love is given all power, both in heaven and on earth;

Seeing that the will of him who loves perfectly is one with the Will of God:

And unto God and Love, all things are possible.

35. We come now to the last and innermost of the fourfold Mysteries of the Cross; the Oblation of God in and for the Macrocosmic Universe.

The fundamental truth embodied in this aspect of the holy symbol, is the doctrine of Pantheism; God, and God 
only, in and through All. The celestial Olympus-Mount of Oracles-is ever creating; God never ceases giving of the Divine Self alike for Creation and for Redemption.

God is in all things, whether personal or impersonal, and in God they live and move and have being. And that stage of purification through which the Kosmos is now passing, is God's Crucifixion; the process of Transmutation and Redemption of Spirit from Matter, of Being from Existence, of Substance from Phenomenon, which is to culminate in the final At-one-ment of the ultimate Sabbath of Rest awaiting God's redeemed universe at the end of the Kalpa. In the Man Crucified we have, therefore, the type and symbol of the continual Crucifixion of God manifest in the flesh, God suffering in the creature, the Invisible made Visible, the Volatile Fixed, the Divine Incarnate, which manifestation, suffering, and crucifixion are the causes of purification and therefore of Redemption. Thus, in the spiritual sense, the six days of creation are always Passion Week, in that they represent the process of painful experience, travail, and passing-through, whereby the Spirit accomplishes the Redemption of the Body, or the return of Matter into Substance. Hence in the sacred writings, God, in the person of Divine Humanity, is represented as showing the Five Mystical Wounds of the Passion to the Angels, and saying:- "These are the Wounds of my Crucifixion, wherewith I am wounded in the House of My Friends." For, so long as pain and sorrow and sin endure, God is wounded continually in the persons of all creatures, small and great; and the temple of their body is the House wherein the Divine Guest suffers.

36. For the Bread which is broken and divided for the children of the Kingdom is the Divine Substance, which with the Wine of the Spirit, constitutes the Holy Sacrament 
of the Eucharist, the Communion of the Divine and the Terrene, the Oblation of Deity in Creation.

37. May this holy Body and Blood, Substance and Spirit, Divine Mother and Father, inseparable Duality in Unity, given for all creatures, broken and shed, and making oblation for the world, be everywhere known, adored, and venerated! May we, by means of that Blood, which is the Love of God and the Spirit of Life, be redeemed, indrawn, and transmuted into that Body which is Pure Substance, immaculate and ever virgin, express Image of the Person of God I That we hunger no more, neither thirst any more; and that neither death, nor life, nor angels, nor principalities, nor powers, nor things present, nor things to come, nor height, nor depth, nor any creature, be able to separate us from the Love of God, which is in Christ Jesus.

That being made one through the At-one-ment of Christ, who only hath Immortality, and inhabiteth Light inaccessible;

We also, beholding the glory of God with open face, may be transformed into the same Image, from glory to glory, by the power of the Spirit. ${ }^{8}$

- Sec C.W.S., part ii., Nos. v., p. 224, and ix., p. 234. 


\section{LECTURE THE FIFTH. ${ }^{1}$}

THE NATURE AND CONSTITUTION OF THE EGO.

\section{PART I.}

I. Evolution as revealed by the facts of physical science is inexplicable on the materialistic hypothesis, as also are the facts of occult experience and science. This is because, by its failure to recognise consciousness as subsisting prior to organism, and inherent in substance, that hypothesis ignores the condition essential to evolution.

2. But for evolution something more even than consciousness is requisite,-namely, memory. For memory is the condition of segregation; the cause and consequence of individuation. Hence every molecule, both in its individual and its collective capacity, is capable of memory; for every experience leaves, in its degree, its impression or scar on the substance of the molecule, to be transmitted to its descendants. This memory of the most striking effects of past experience, is the differentiating cause which, accumulated over countless generations, leads up from the

1 This lecture was written by Edward Maitland for the Second Edition of The Perfect Way, in which Edition it was substituted for the fifth lecture of the First Edition (see Pref.). It was written almost entirely from revelations received by Anna Kingsford, Edward Maitland's own independent contributions to it being paragraphs 27 to 29 and 45 to 47. On the 29th June, 1886, it was delivered by Edward Maitland as a lecture to the Hermetic Society (Life of $A$. $K$., vol. ii., pp. 17, 32). For the fifth lecture of the First Edition, see App. No. I. 
ameba to man. Were there no such memory, instead of progress, or evolution, there would be a circle returning into and repeating itself; whereas, the modifying effects of accumulated experience convert what would otherwise be a circle into a spiral, whose eccentricity-though imperceptible at the outset-becomes greater and more complex at every step. ${ }^{2}$

3. Consciousness being inherent in substance, every molecule in the universe is able to feel and to obey after its kind,-the inorganic as well as the organic, between which there is no absolute distinction as ordinarily supposed. For even the stone has a moral platform, embracing a respect for and obedience to the laws of gravitation and chemical affinity. Wherever there are vibration and motion, there are life and memory; and there are vibration and motion at all times and in all things. Herein may be seen the cause of the failure of the attempt to divide the ego from the non-ego. Strictly speaking, there is only one thing and one action; for unconsciousuess is no more a positive thing than darkness. It is the privation, more or less complete, of consciousness, as obscurity is of light.

4. We come to speak of the substantial ego, the soul or Psyche, the superior human reason, the nucleus of the human system. ${ }^{8}$ In every living entity there are four inherent powers. We are speaking now not of component parts, but of forces. The first and lowest mode of power is the mechanical; the second is the chemical; the third is the electrical, - an order which includes the mental; and the fourth is the psychical. The first three belong to

2 See Unconscious Memory, ch. xiii., by S. Butler, 1880.

3sing the term Psyche in the higher sense usually attached to it by the post-Homeric Greeks, and not that of the animal life as by Paul. 
the domain of physiological science; the last to that of spiritual science. It is this last mode of power which belongs to the "Immaculate" and Essential. It is inherent in the Substantial, and is, therefore, a permanent and indefeasible quantity. It is in the Archë, and is wherever there is organic life. Thus is Psyche at once the "living mother" and "mother of the living." And she is from the Beginning latent and diffused in all matter. She is the unmanifest, by the divine Will made manifest ; the invisible, by energy made visible. Wherefore every manifested entity is a Trinity, whose three "persons" are,-(I) that which makes visible; (2) that which is made visible; and (3) that which is visible. Such are Force, Substance, and the expression or "Word" of these, their Phenomenon.

5. Of this Energy, or Primordial Force, there are two modes, - for everything is dual, - the centrifugal, or accelerating force, and the centripetal, or moderating force; of which the latter, in being derivative, reflex, and complementary, is as feminine to the other's masculine. By means of the first mode substance becomes matter. By means of the second mode substance resumes her first condition. In all matter there is a tendency to revert to substance, and hence to polarise Soul by means of evolution. For the instant the centrifugal mode of force comes into action, that instant its derivative, the centripetal force, begins also to exercise its influence. And the primordial substance has no sooner assumed the condition of matter, than matter itself begins to differentiate,-being actuated by its inherent force,-and by differentiation to beget individualities.

6. Then Psyche, once abstract and universal, becomes concrete and individual, and through the gate of matter issues forth into new life. A minute spark in the globule, 
she becomes-by continual accretion and centralisation -a refulgent blaze in the globe. As along a chain of nerve-cells the current of magnetic energy flows to its central point, - being conveyed, as is a mechanical shock, along a series of units, - with ever-culminating impetus, so is the psychic energy throughout nature developed. Hence the necessity of centres, of associations, of organisms. And thus, by the systematisation of congeries of living entities, that which in each is little, becomes great in the whole. The quality of Psyche is ever the same; her potentiality is invariable.

7. Our souls, then, are the agglomerate essences of the numberless consciousnesses composing us. They have growen, evolving gradually from rudimentary entities which were themselves evolved, by polarisation, from gaseous and mineral matter. And these entities combine and coalesce to form higher-because more complex-entities, the soul of the individual representing the combined forces of their manifold consciousnesses, polarised and centralised into an indefeasible unity.

8. While the material and the psychical are to each other respectively the world of Causes and the world of Effects, the material is, itself, the effect of the spiritual, being the middle term between the spiritual and the psychical. It is therefore true that organism is the result of Idea, and that Mind is the cause of evolution. The explanation is, that Mind is before matter in its abstract, though not in its concrete condition. This is to say, that Mind, greater than, and yet identical with, that which results from organism, precedes and is the cause of organism.

9. This Mind is God, as subsisting prior to and apart from creation, which is manifestation. God is spirit or essential substance, and is impersonal if the term persona 
be taken in its etymological sense, but personal in the highest and truest sense if the conception be of essential consciousness. For God has no limitations. God is a pure and naked fire burning in infinitude, whereof a flame subsists in all creatures. The Kosmos is a tree having innumerable branches, each connected with and springing out of various boughs, and these again originating in and nourished by one stem and root. And God is a fire burning in this tree, and yet consuming it not. God is I AM. Such is the nature of infinite and essential Being. And such is God before the worlds. ${ }^{4}$

Io. What, then, is the purpose of evolution, and separation into many forms, - the meaning, that is, of Life? Life is the elaboration of soul through the varied transformations of matter.

Spirit is essential and perfect in itself, having neither beginning nor end. Soul is secondary and perfected, being begotten of spirit. Spirit is the first principle, and is abstract. Soul is the derivative, and is therefore concrete. Spirit is thus the primary Adam; and Soul is Eve, the "woman " taken out of the side of the "man."

I I. The essential principle of personality-that which constitutes personality in its highest sense-is consciousness, is spirit; and this is God. Wherefore the highest and innermost principle of every monad is God. But this primary principle-being naked essence-could not be separated off into individuals unless contained and limited by a secondary principle. This principle-being derived -is necessarily evolved. Spirit, therefore, is projected into the condition of matter in order that soul may be evolved thereby. Soul is begotten in matter by means

4 Terms implying succession, when used in relation to the infinite and eternal, are to be understood logically, not chronologically. 
of polarisation; and spirit, of which all matter consists, returns to its essential nature in soul - this being the medium in which spirit is individuated-and from abstract becomes concrete; so that by means of creation God the One becomes God the Many.

\section{PART II.}

12. We have spoken of an outer personality and an inner personality, and of a material consciousness as differing from a spiritual consciousness. We have now to speak of a spiritual energy as differing from a material energy. The energy whereby the soul polarises and accretes, is not dependent upon the undulations of the ether as are material energies. The astral ether is the first state of matter. And to the first state of matter corresponds the primordial force, the rotatory, or centrifugal and centripetal in one. But before and within force is Will; that is, Necessity, which is the will of God. It is inherent in substance, which is the medium in which it operates. Such as the primordial will is in relation to the primordial substance, the individual will is to the derived soul. And when the current of spiritual energy, or will, is strong enough in the complex organism to polarise and kindle centrally, then the individual Psyche conceives Divinity within her and becomes God-conscious. In the rudimentary stages of matter, this current is not strong enough or continuous enough thus to polarise.

13. When Psyche has once gathered force sufficient to burn centrally, her flame is not quenched by the disintegration of the physical elements. These, indeed, fall asunder and desquamate many times during life; yet the consciousness and memory remain the same. We have not 
in our physical bodies a single particle which we had some few years ago, and yet our ego is the same and our thought continuous. The Psyche in us, therefore, has grown up out of many elements; and their interior egos are perpetuated in our interior ego, because their psychic force is centralised in our individuality. And when our Psyche is disengaged from the disintegrating particles of our systems, she will $x$-after due purgation-go forth to new affinities and the reversion of matter to substance will still continue.

14. Is it asked,-If the soul be immaculate, how comes she to be attracted by material affinities? The reply is, that the link between her and earth is that which the Hindus call Karma, namely, the results of past conduct, and consequent destiny. Immaculate though she be in her virginal essence, Psyche is not the "espoused Bride" until the bond between her and the earth be severed. And this can be only when every molecule of her essence is pervaded by spirit, and indissolubly married therewith, as God with Arche in the Principle.

The soul, like water, can never really be other than efsimmaculate," and hence the peculiar propriety of water as the mystical symbol for the soul. Being a chemical combination of two gases-hydrogen and oxygen-themselves pure, water itself also is pure, and cannot be other- wise. The condition called foulness occurs, not by the admission of foreign substances entering into combination with it, but only by mechanical admixture with these, and the holding of them in suspension in such wise that they may be eliminated by distillation. Such is the relation of the soul to "sin." When regeneration - the equivalent of distillation-is accomplished, "Karma" is no longer operative. 


\section{PART III.}

15. The law inherent in the primordial substance of matter obliges all things to evolve after the same mode. The worlds in the infinite abyss of the heavens are in all respects similar to the cells in vegetable or animal tissue. Their evolution is similar, their distribution similar, and their mutual relations are similar. For this reason we may, by the study of natural science, learn the truth not only in regard to this, but in regard also to occult science; for the facts of the first are as a mirror to the facts of the last.

16. We have already said that our souls are the agglomerate essences of the numberless consciousnesses composing us. Our souls are not, however, limited in capacity to the sum total of those consciousnesses as they are in their separate state; but represent them combined into One Life and polarised to a plane indefinitely higher. For the synthetical resultant thus attained is not a mere aggregate of constituents; but represents a new condition of these, precisely as in chemistry $\mathrm{H}_{2} \mathrm{O}$-the symbol for waterrepresents a new condition of $2 \mathrm{H}+\mathrm{O}$, and differs from it by a reformulation of state. After such a reformulation, the sum of the activities of the molecules of the resulting product is different from that previously possessed by its factors. In such sense is to be understood the synthesis of consciousness by means of which our individuality is constituted; and-referring this synthetic energy to a yet higher plane-the formulation of the God-consciousness peculiar to our world. This idea was familiar to the ancients. They were wont to regard every heavenly orb as a deity, having for his material body the visible planet; for his astral nature, its vegetable and animal intelligences; and for his Soul, man's substantial part; his spirit being 
the Nous of man, and therefore Divine. And as, when speaking of the planet-God they specially meant that Nous, it was said with truth that our Divine part is no other than the planet-God,-in our case Dionysos, or Jehovah-Nissi, the "God of the emerald" or green earth, called also Iacchos, the mystic Bacchos. ${ }^{5}$

17. Such as all creatures composing the planet are to the planet, all the planets are to the universe, and such are the Gods to God (in manifestation). The supreme Ego of the universe is the sum total of all the Gods; His Personality is their agglomerate personality; to pray to Him is to address all the celestial host, and, by inclusion, the souls of all just men. But as in man the central unity of consciousnesses constituted of the association of all the consciousnesses of his system, is more than the sum total of these, inasmuch as it is on a higher level; -so in the planet and the universe. The soul of the planet is more than the associated essences of the souls composing it. The consciousness of the system is more than that of the associated world-consciousnesses. The consciousness of the manifest universe is more than that of the corporate systems; and that of the Unmanifest Deity is greater than that of them all. For the Manifest does not exhaust the Unmanifest ; but "the Father is greater than the Son." ${ }^{6}$

18. And here it is necessary that this distinction between the manifest and unmanifest God be insisted on and defined. "No man," it is declared, "hath seen the Father at any time," because the Father is Deity unmanifest. And again, "He that hath seen the Son, hath seen the Father

${ }^{5}$ See $C . W . S$. , part ii., No. xiii., pp. 251-260. The Earth's place in the "Seven Planets" is that of the green ray in the spectrum. Hence the emerald "Tablet of Trismegistus" and signet of the Popes.

${ }^{6}$ See C.W.S., part i., No. 1., p. 204. 
also," because the Son is Deity in manifestation, and is the "Express Image" or Revelation of the Father, being brought forth in the "fulness of time" as the crown of kosmic evolution. This latter mode of Deity is therefore synthetical and cumulative; the terminal quantity of the whole series of the universal Life-process (Lebens-prozess) as exhibited in successive planes of generative activity, the Omega of concretive developments. But the Father is Deity under its abstract mode, logically precedent to and inclusive of the secondary and manifest mode; the Alpha of all things and processes, the supra-kosmic, primordial Being, impersonal (in the etymological sense of the term) and unindividuated; that wherein consciousness subsists in its original mode, and whereby it is subsequently conditioned and compelled. This unmanifest Deity must necessarily represent some mode of Selfhood; but its nature remains inscrutable to us, and can be known only through the Person of the Son;-that is, in manifestation.

The difference between the two modes of Deity finds apt illustration in the physiology of embryonic development. The first condition of the fecundated ovum is one of generalised and informulate vitality. An activity, at once intelligent and unindividuated, permeates the mass of potential differentiations, and directs their manifestation. Under the direction of this inherent activity, the mass divides, segregates, and constitutes itself into discrete elements; and these in their turn sub-divide, and elaborate new individuations; until, by means of successive aggregations of cellular entities, various strata and tissues are formed. In this way is built up, little by little, a new glomerate creature, the consciousness of which, though manifold and diverse, is yet one and synthetic. But this synthetic individuality is not of itself. It was begotten in 
the bosom of the inherent and primordial intelligence pervading the essential matter out of which it was constructed, and to which, as Father, it is Son.

19. The Gods are not limited in number. Their numbers denote orders only. Beyond number are the orbs in infinite space, and each of them is a God. Each globe has its quality corresponding to the conditions of the elements which compose it. And every physical world of causes has its psychic world of effects. All things are begotten by fission, or section, in a universal protoplast; and the power which causes this generation is centrifugal.

20. God unmanifest and abstract is the Primordial Mind, and the kosmic universe is the ideation of that Mind. Mind in itself is passive; it is organ, not function. Idea is active; it is function. As soon, therefore, as Mind becomes operative, it brings forth Ideas, and these constitute existence. Mind is abstract; Ideas are concrete. To think is to create. Every thought is a substantial action. Wherefore Thoth-Thought-is the creator of the Kosmos. Hence the identification of Hermes (Thoth) with the Logos.

$2 \mathrm{r}$. Nevertheless, there is but one God; and in God are comprehended all thrones, and dominions, and powers, and principalities, and archangels and angels in the celestial world,-called by Kabbalists the "Exemplary World," or world of archetypal ideas. And through these are the worlds begotten in time and space, each with its astral sphere. And every world is a conscient individuality. Yet they all subsist in one consciousness, which is one God. For all things are of spirit, and God is spirit, and spirit is consciousness.

22. The science of the Mysteries is the climax and crown of the physical sciences, and can be fully understood only 
by those who are conversant therewith. Without this knowledge it is impossible to comprehend the basic doctrine of occult science, the doctrine of Vehicles. The knowledge of heavenly things must be preceded by that of earthly things. "If, when I have spoken to you of earthly things, you understand not," says the Hierophant to his neophytes, "how shall you understand when I speak to you of heavenly things?" It is vain to seek the inner chamber without first passing through the outer. Theosophy, or the science of the Divine, is the Royal Science. And there is no way to reach the King's chamber save through the outer rooms and galleries of the palace. Hence one of the reasons why occult science cannot be unveiled to the generality of men. To the uninstructed no truth is demonstrable. Nor can anyone who has not learned to appreciate the elements of a problem, appreciate its solution.

23. All the component consciousnesses of the individual polarise to form a unity, which is as a sun to his system. But this polarisation is fourfold, being distinct for each mode of consciousness. And the central, innermost, or highest point of radiance-and it alone-is subjective. They who stop short at the secondary consciousness and imagine it to be the subjective, have failed to penetrate to the innermost and highest point of the consciousness in themselves, and in so far are defective as to their humanity. Whereas they who have developed in themselves the consciousness of every zone of the human system, are truly human, and do, of themselves, represent humanity as no majority, however great, of undeveloped and rudimentary men can do. Being thus, they represent Divinity also. Theocracy consists in government by them.

24. Let us take for illustration the image of an incandescent globe, or ball of fire, fluid and igneous throughout 
its whole mass. Supposing this globe divided into several successive zones, each containing its precedent, we find that only the central interior zone contains the radiant point, or heart of the fiery mass, and that each successive zone constitutes a circumferential halo, more or less intense according to its nearness to the radiant point; but secondary and derived only, and not in itself a source of luminous radiation.

25. It is thus with the macrocosm, and also with the human kingdom. In the latter the soul is the interior zone, and that which alone contains the radiant point. By this one, indivisible effulgence the successive zones are illuminated in unbroken continuity; but the source of it is not in them. And this effulgence is consciousness, and this radiant point is the spiritual ego or Divine spark. God is the Shining One, the radiant point of the universe. God is the supreme consciousness, and the Divine radiance also is consciousness. And man's interior ego is conscient only because the radiant point in it is Divine. And this consciousness emits consciousness; and transmits it, first, to the Psyche; next, to the anima bruta; and last, to the physical system. The more concentrated the consciousness, the brighter and more effulgent the central spark.

26. Again: if from the midst of this imagined globe of fire the central incandescent spark be removed, the whole globe does not immediately become dark; but the effulgence lingers in each zone according to its degree of proximity to the centre. And it is thus when dissolution occurs in the process of death. The anima bruta and physical body may retain consciousness for a while after the soul is withdrawn, and each part will be capable of memory, thought, and reflection according to its kind.

27. Apart from the consciousness which is of the Psyche, 
man is necessarily agnostic. For, of the region which, being spiritual and primary, interprets the sensible and secondary, he has no perception. He may know things, indeed, but not the meaning of things; appearances, but not realities; resultant forms, but not formative ideas; still less the source of these. The world and himself are fellow-phantoms; aimless apparitions of an inscrutable something, or, may-be, nothing; a succession of unrelated, unstable states.

28. From this condition of non-entity, the spiritual consciousness redeems him, by withdrawing him inward from materiality and negation, and disclosing to him a noumenal and, therefore, stable ego, as the cogniser of the unstable states of his phenomenal ego. The recognition of this noumenal ego in himself involves the recognition of a corresponding ego, of which it is the counterpart, without himself:--involves, that is, the perception of God. For the problem of the ego in man is the problem also of God in the universe. The revelation of one is the revelation of both, and the knowledge of either involves that of the other. Wherefore for man to know himself, is to know God. Selfconsciousness is God-consciousness. He who possesses this consciousness, is, in such degree, a Mystic.

29. That whereby the mystic is differentiated from other men, is degree and quality of sensitiveness. All are alike environed by one and the same manifold Being. But whereas the majority are sensitive to certain planes or modes only, and these the outer and lower, of the common environment, he is sensitive to them all, and especially to the inner and higher; having developed the corresponding mode in himself. For man can recognise without himself that only which he has within himself. The mystic is sensitive to the God-environment, because God is Spirit, and he has developed his spiritual consciousness. That 
is, he has and knows his noumenal ego. Psyche and her recollections and perceptions are his.

30. Hence the radiant point of the complex ego must be distinguished from its perceptive point. The first is always fixed and immutable. The second is mutable; and its position and relations vary with different individuals. The consciousness of the soul, or even-in very rudimentary beings - of the mind, may lie beyond the range of the perceptive consciousness. As this advances and spreads inwards, the environment of the ego concerned expands; until, when, finally, the perceptive point and the radiant point coincide, the ego attains regeneration and emancipation.

3r. When the physiologists tell us that memory is a biological processus, and that consciousness is a state dependent upon the duration and intensity of molecular nervous vibration, a consensus of vital action in the cerebral cells; a complexity, unstable and automatic, making and unmaking itself at each instant, as does the material flame, and similarly evanescent, - they do not touch the Psyche. For what is it that cognises these unstable states? To what Subject do these successive and ephemeral conditions manifest themselves, and how are they recognised? Phenomenon is incapable of cognising itself, and appears not to itself, being objective only. So that unless there be an inner, subjective ego to perceive and remember this succession of phenomenal states, the condition of personality would be impossible; whereas, there is of necessity such an ego; for apparition and production are processes affecting - and therefore implying-a subject. Now this subject is, for man, the Psyche; for the universe, God. In the Divine mind subsist eternally and substantially all those things of which we behold the appearances. And as in nature there 
are infinite gradations from simple to complex, from coarse to fine, from dark to light, so is Psyche reached by innumerable degrees; and they who have not penetrated to the inner, stop short at the secondary consciousness, which is ejective only, and imagine that the subjective-which alone explains all-is undemonstrable.

Nemo psych of practice of seeking unity in the simple, rather than in the complex. They thus reverse and invert the method of evolution, and nullify its end. They refuse unity to the man, in order to claim it for the molecule alone. Claiming unity and, thereby, individuality, for the ultimate element, indivisible and indestructible by thought,-for the simple monad only, - they divinise the lowest instead of the highest, and so deprive evolution of its motive and end. Whereas Psyche is the most complex of extracts; and the dignity and excellence of the human soul consist, not in her simplicity, but in her complexity. She is the summit of evolution, and all generation works in order to produce her. The occult law which governs evolution brings together, in increasingly complex and manifold entities, innumerable unities, in order that they may, of their substantial essence, polarise one complex essential extract:--complex, because evolved from and by the concurrence of many simpler monads:-essential, because in its nature ultimate and indestructible. The human ego is, therefore, the synthesis, the Divine Impersonal personified; and the more sublimed is this personality, the profounder is the consciousness of the Impersonal. The Divine consciousness is not ejective, but subjective. The secondary personality and consciousness are to the primary as the water reflecting the heavens; the nether completing and returning to the upper its own concrete reflex. 
33. It is necessary clearly to understand the difference between the objective and ejective on the one hand, and the subjective on the other. The study of the material is the study of the two former; and the study of the substantial is the study of the latter. That, then, which the biologists term the subjective, is not truly so, but is only the last or interior phase of phenomenon. Thus, for example, the unstable states which constitute consciousness, are, in their view, subjective states. But they are objective to the true subject, which is Psyche, because they are perceived by this latter, and whatever is perceived is objective. There are in the microcosm two functions, that of the revealer, and that of the entity to which revelation is made. The unstable states of the biologist, which accompany certain operations of organic force, are so many modes whereby exterior things are revealed to the interior subject. Constituting a middle term between object and subject, these states are strictly ejective, and are not, therefore, the subject to which revelation is made. It is hopeless to seek to attain the subjective by the same method of study which discovers the ejective and objective. We find the latter by observation from without; the former by intuition from within. The human kosmos is a complexity of many principles, each having its own mode of operation. And it is on the rank and order of the principle affected by any special operation that the nature of the effect produced depends. When, therefore, for example, the biologist speaks of unconscious cerebration, he should ask himself to whom or to what such cerebration is unconscious, knowing that in all vital processes there is infinite gradation. Questions of duration affect the mind; questions of intensity affect the Psyche. All processes which occur in the objective are relative to something; there is but one thing absolute, and 
that is the subject. Unconscious cerebration is therefore only relatively unconscious in regard to that mode of perception which is conditioned in and by duration. But inasmuch as any such process of cerebration is intense, it is perceived by that perceptive centre which is conditioned by intensity; and in relation to that centre it is not unconscious. The interior man being spiritual, knows all processes; but many processes are not apprehended by the man merely mental. We see herein the distinction between the human principles, and their separability even on this plane of life. And if our mundane ego and our celestial ego be so distinct and separable even while vitally connected, that a nervous process conscious to the latter is unconscious to the former, much more shall separability be possible when the vital bond is broken. If the polarities of our entire system were single and identical in direction, we should be conscious of all processes and nothing would be unknown to us ; because the central point of our perception would be the precise focus of all convergent radii. But no unregenerate man is in such case. In most men the perceptive point lies in the relative man,-ejective or objective, -and by no means in the substantial and subjective man. Thus the convergent radii pass unheeded of the individual consciousness, because, as yet, the man knows not his own spirit. Being thus incapable of absolute cognition, such as these may be said to be asleep while they live.

\section{PART IV.}

34. The higher the entity undergoing death, the easier is the detachment of the Psyche from the lower consciousnesses by which she is enshrined. 'The saint does not fear death, because his consciousness is gathered up into his Psyche, and she into her spouse the Spirit. Death, for 
him, is the result, not of any pathological process, but of the normal withdrawal, first, of the animal life into the astral or magnetic; and, next, of this into the psychic, to the reinforcement of the latter; precisely as in the cell about to disintegrate, its protoplasmic contents are seen to become better defined and to increase, as their containing capsule becomes more tenuous and transparent. In this wise have passed away saints and holy men innumerable of all lands and faiths; and with a dissolution of this kind the relations of the redeemed Psyche with materiality may terminate altogether. Such an end is the consummation of the redemption from the power of the body, and from the "sting of death." Forasmuch, however, as the righteous has attained this condition by what Paul calls "dying daily" during a long period to the lower elements, death for him - whatever the guise in which it may finally come-is no sudden event, but the completion of a process long in course of accomplishment. That which to others is a violent shock, comes to him by insensible degrees, and as a release wholly comfortable. Hence the aspiration of the prophet, "Let me die the death of the just, and let my last end be like his."

35. In dissolution, the consciousness speedily departs from the outermost and lowest sphere, that of the physical body. In the shade, spectre, or astral body (Hebrew, Nephesh)-which is the lowest mode of soul-consciousness lingers a brief while before being finally dissipated. In the astral soul, anima bruta, or ghost (Hebrew, Ruach) consciousness persists-it may be for centuries-according to the strength of the lower will of the individual, manifesting the distinctive characteristics of his outer personality. In the soul (Hebrew, Neshamah) - the immediate receptacle of the Divine Spirit-the consciousness is everlasting as the 
soul herself. And while the ghost 'remains below in the astral sphere, the soul, obeying the same universal law of gravitation and affinity, detaches herself and mounts to the higher atmosphere suited to her;-unless, indeed, she be yet too gross to be capable of such aspiration. In which case, she remains "bound" in her astral envelope as in a prison. This separability of principles is recognised in Homer when Odysseus is made to say of his interview with the shades:- "Then I perceived Herakles, but only in phantom ( $\epsilon$ " $\delta \omega \lambda \nu v)$, for he himself is with the gods." 7

36. The ghosts of the dead resemble mirrors having two opposed surfaces. On the one side they reflect the earth-sphere and its pictures of the past. On the other they receive influxes from those higher spheres which have received their higher, because spiritual, egos. The interval between these principles is, however, better described as of state or condition than as of locality. For this belongs to the physical and mundane, and for the freed soul has no existence. There is no far or near in the Divine.

37. The ghost, however, has hopes which are not without justification. It does not all die, if there be in it anything worthy of recall. The astral sphere is then its place of purgation. For Saturn, who as Time is the Trier of all things, devours all the dross, so that only that escapes which in its nature is celestial and destined to reign. The soul, on attaining Nirvâna, gathers up all that it has left in the astral of holy memories and worthy experiences. To this end the ghost rises in the astral by the gradual decay and

7 As pointed out by Dr. Hayman, Pindar similarly emphasises the distinction between the hero and his immortal essence. And Chaucer has the line: "Though thou here walke, thy spirit is in helle" (Man of Law's Tale). These distinctions are more than poetic imaginings. They represent occult knowledges as verified by the experience of all ages. 
loss of its more material affinities, until these have so disintegrated and perished that its substance is thereby enlightened and purified. But continued commerce and intercourse with earth add, as it were, fresh fuel to its earthly affinities, keeping these alive, and so hinder its recall to its spiritual ego. And thus, therefore, the spiritual ego itself is detained from perfect absorption into, and union with, the Divine.

38. This dissolution of the ghost is gradual and natural. It is a process of disintegration and elimination extending over periods which are greater or less according to the character of the individual. Those ghosts which have belonged to evil persons possessed of strong wills and earthly tendencies, persist longest and manifest most frequently and vividly, because they do not rise, but-being destined to perishare not withdrawn from immediate contact with the earth. These are all dross, having in them no redeemable element. The ghost of the righteous, on the other hand, complains if his evolution be disturbed. "Why callest thou me?" he may be regarded as saying: "disturb me not. The memories of my earth-life are chains about my neck ; the desire of the past detains me. Suffer me to rise towards my rest, and hinder me not with evocations. But let thy love go after me and encompass me; so shalt thou rise with me through sphere after sphere." Thus even though, as often happens, the ghost of a righteous person remains near one who, being also righteous, has loved him, it is still after the true soul of the dead that the love of the living friend goes, and not after his lower personality represented in the ghost. And it is the strength and divinity of this love which helps the purgation of the soul, being to it an indication of the way it ought to go, "a light shining upon the upward path" which leads from the earthly to the celestial and everlasting. 
For the good man upon earth can love nothing other than the Divine. Wherefore, that which he loves in his friend is the Divine,- his true and radiant self. ${ }^{8}$

\section{PART V.}

39. Of the four constituent spheres of the planet one subsists in two conditions, present and past. This is its magnetic atmosphere or astral soul, called the Anima Mundi. In the latter condition it is the Picture-world wherein are stored up all the memories of the planet; its past life, its history, its affections and recollections of physical things. The adept may interrogate this phantom-world, and it shall speak for him. It is the cast-off vestment of the planet; yet it is living and palpitating, for its very fabric is spun of psychic substance, and its entire parenchyma is magnetic. And forasmuch as the planet is an entity ever being born and ever dying; so this astral counterpart of itself, which is the mirror of the globe, a world encompassing a world, is ever in process of increase.

40. What the disintegrating Ruach is to man, this astral zone is to the planet. In fact, the great magnetic sphere of the planet is itself composed and woven out of the magnetic egos of its offspring, precisely as these in their turn are woven out of the infinitely lesser atoms which compose the individual man. So that, by a figure, we may represent the whole astral atmosphere of the planet as a system of so many minute spheres, each reflecting and transmitting special rays. But as the Divine Spirit of the planet is not in its magnetic circle, but in the celestial; so the true soul and spirit of the man are not in this astral sphere, but are of the higher altitudes.

'See C.W.S., part i., No. xl., p. 156, and part ii., No. xiv. (2), p. 270. 
4I. Each world has its astral soul which remains always with it. But the world's true soul migrates and interchanges, which is the secret of the creation of worlds. Worlds, like men, have their karma ; and new kosmic globes arise out of the ruins of former states. As the soul of the individual human unit transmigrates and passes on, so likewise does the Psyche of the planet. From world to world, in ceaseless intercourse and impetus, the living Neshamah pursues her variable way. And as she passes, the tincture of her divinity changes. Here, her spirit is derived through Iacchos; there through Aphrodite; and, again, through Hermes, or another god. Here, again, she is weak; and there, strong. Our planet-it must be understood-did not begin this Avatâr in strength. An evil karma overwhelmed its soul;-a karma which had endured throughout the last pralaya,-or interval intervening between the former period of vivification of the planet and its rebirth to new activities, -and which, from the outset of the fresh manifestation-commonly called creation-dominated the reconstruction of things. This planetary karma was, by the Scandinavian theology, presented under the figure of the "golden dice of destiny," which, after the "twilight of the Gods," or "night of the Kalpa,"9 were found again unchanged in the growing grass of a new risen earth. For, as the kabbalistic interpreters of Genesis teach, the moral formations of all created things preceded their objective appearance. So that "every plant of the field before it sprang, and every herb of the ground before it grew," had its "generation" unalterably determined. And, so long as these moral destinies which constitute the planetary karma remain operative, so long the process of alternate passivity and activity will continue. The revolutions and evolutions

${ }^{9}$ Hindû term for the period of kosmic manifestation. 
of matter, the interchanges of destruction and renovation, mark the rhythmic swing of this resistless force, the expression of essential Justice. But with every cyclic wave that breaks shoreward, the tide rises. "The might of the Gods increases : the might of the powers of evil dwindles." 10

42. As with man so with the planet. For small and great there is One Law; though one star differs from another in glory. And so throughout the infinite vistas and systems of the heavens. From star to star, from sun to sun, from galaxy to galaxy, the kosmic souls migrate and interchange. But every God keeps his tincture and maintains indefeasibly his personality.

\section{PART VI.}

43. To apply what has been said to the elucidation of Catholic doctrine and practice. The object set before the saint is so to live as to render the soul luminous and consolidate with the spirit, that thereby the spirit may be perpetually one with the soul, and thus eternise its individuality. For individuality appertains to the soul, inasmuch as it consists in separateness, which it is the function of soulsubstance to accomplish in respect of spirit. ${ }^{11}$ Thus, though

10 The Dharmasastra Sutras.

"While Christianity teaches the everlasting persistence of the acquired personality of the redeemed, and makes redemption consist in this, Buddhism insists that personality is an illusion belonging to the sphere of existence, - as distinguished from Being, - and makes redemption consist in the escape from it. But the difference between the two doc. trines is one of presentation only, and is not a real difference. The explanation is, that there are to each individual two personalities or selfhoods, the one exterior and phenomenal, which is transient, and the other interior and substantial, which is permanent. And while Budd. hism declares truly the evanescence of the former, Christianity declares truly the continuance of the latter. It is the absorption of the individual into this inner and divine selfhood, and his consequent with. drawal from Existence, that constitutes Nirvana, "the peace that passeth understanding." 
eternal and immaculate in her substance, the soul acquires individuality by being born in matter and time; and within her is conceived the divine element which, divided from God, is yet God and man. Wherefore Catholic dogma and tradition, while making Mary the "mother of God," represent her as born of Anna, the year, or time."2

44. The two terms of the history of creation, or evolution, are formulated by the Church in two dogmas. These are (I), the Immaculate Conception, and (2), the Assumption, of the Blessed Virgin Mary. ${ }^{13}$ The former concerns the generation of the soul, presenting her as begotten in the womb of matter, and by means of matter brought into the world, and yet not of matter, but from the first moment of her being, pure and incorrupt. Otherwise she could not be "Mother of God." In her bosom, as Nucleus, is conceived the bright and holy Light, the Nucleolus, which-without participation of matter-germinates in her and manifests itself as the express image of the Eternal and Ineffable Self-

12 The Hebrew forms of these names-Miriam and Hannah-do not bear quite the same meanings. But, as is obvious from the analogies used and accepted in Catholic teaching, the name of the Virgin has always been related to its Latin signification, so that it is consistent to accept the name of her mother in accordance with this practice, especially as the latter is not mentioned by any of the Evangelists, but occurs only in Latin tradition.

13 It is true that the doctrine of the Assumption is not a dogma in the technical sense of the term, inasmuch as it has not yet been formally promulgated as an article of faith. But it has always subsisted in the Church as a "pious belief," and in promulgating it we are but anticipating the Church's intention;--excepting that we present it as a conclusion of reason no less than as an article of faith. How far our action may be agreeable to ecclesiastical authority we have not thought necessary to inquire. Neither deriving our information from ecclesiastical sources, nor being under ecclesiastical direction, we commit no breach of ecclesiastical propriety. In any case it has the notable effect of securing the fulfilment of the prophecy implied in the choice of his official title and insignia by Pope Leo XIII. - the prophecy that his pontificate should witness the promulgation in question. For further explanation see Lect. VI., 39. 
hood. To this image she gives individuality; and through and in her it is focused and polarised into a perpetual and self-subsistent Person, at once human and Divine, Son of God and of man. Thus is the soul at once Daughter, Spouse, and Mother of God. By her is crushed the head of the Serpent. And from her triumphant springs the Man Regenerate, who, as the product of a pure soul and divine spirit, is said to be born of water (Maria) and the Holy Ghost.

45. The declarations of Jesus to Nicodemus are explicit and conclusive as to the purely spiritual nature both of the entity designated "Son of Man," and of the process of his generation. Whether incarnate or not, the "Son of Man" is of necessity always "in heaven,"-his own "kingdom within." Accordingly the terms describing his parentage are devoid of any physical reference. "Virgin Maria" and "Holy Ghost" are synonymous, respectively, with "Water" and "the Spirit"; and these, again, denote the two constituents of every regenerated selfhood, its purified soul and divine spirit. Wherefore the saying of Jesus, - "Ye must be born again of Water and of the Spirit," was a declaration, first, that it is necessary to every one to be born in the manner in which he himself is said to have been born; and, next, that the Gospel narrative of his birth is really a presentation, dramatic and symbolical, of the nature of regeneration.

46. As the Immaculate Conception is the foundation of the Mysteries, so the Assumption is their crown. For the entire object and end of kosmic evolution is precisely this triumph and apotheosis of the soul. In this Mystery is beheld the consummation of the whole scheme of creation, - the perfectionment, perpetuation, and glorification of the individual human ego. The grave-that is the astral 
and material consciousness- -cannot retain the Mother of God. She rises into heaven; she assumes its Queenship, and is-to cite the "Iittle Office of the Blessed Virgin Mary"- "taken up into the chamber where the King of kings sits on His starry throne"; her festival, therefore, being held at the corresponding season in the astronomical year, when the constellation Virgo reaches the zenith and is lost to view in the solar rays. Thus, from end to end, the mystery of the soul's evolution-the argument, that is, of the kosmic drama and the history of Humanity-is contained and enacted in the cultus of the Blessed Virgin. The Acts and the Glories of the soul as Mary are the one and supreme theme of the sacred Mysteries. ${ }^{14}$

47. Now this discourse on the nature and constitution of the Ego, is really a discourse on the nature and constitution of the Church of Christ. ${ }^{15}$

${ }^{14}$ See $C . W . S .$, part. i., No. xlviii. (2), p. 198.
15 See $C . W . S .$, part i., No. l., p. 204 . 


\section{LECTURE THE SIXTH. ${ }^{1}$}

THE FALL (No. I.).

\section{PART I.}

I. IN the city of Mecca, the birthplace of the iconoclast Mohammed, is a square edifice thirty feet high, called the Kaabeh, or Cube. The Koran says that it was the first house of worship built for mankind. It has been known from time immemorial as Beit-Allah, which name is the exact equivalent of the Hebrew word Beth-El, House of God. According to Moslem legend it was originally built by Adam, after the pattern of a similar structure in Paradise, and was restored by Abraham. It contains a white stone, - now blackened by time and by the kisses of pilgrims, which stone was also, according to tradition, brought from Paradise. But, ages before the birth of Mohammed, the Kaabeh was an object of veneration as a Pantheon of the Gods, and the white stone was adored as a symbol of Venus.

2. This cubic House is a figure of the Human Kingdom framed on the pattern of the Universal Kingdom constructed in the primal Age, or "Beginning." And the original builder of the Kaabeh is said to have been Adam,

1 This lecture was written by Anna Kirigsford, with the exception of pars. 28 and 29 , which were written by Edward Maitland: and was delivered by her on Monday the $27^{\text {th }}$ Junc, 1 SSI (Life of $A . K$., vol. ii., pp. 16, 17, 20, 32). 
"Adam" in one aspect representing the first Church of the Elect, the first Community of men "made in the Image of God." This Church, having forfeited "Paradise" and fallen away from perfection, was restored by Abraham, the Father of the Faithful or Initiates, this great Ancestor of the chosen people of God being in one aspect the personified Church of Brahma in India, whence the Mysteries "went down into Egypt," and ultimately into all the world. The name Beth-El given to the Human House, denotes that man, when "cubic" or six-fold, is the habitation of Deity. For in their interior and primary meaning these six stages or "days" of the creative week of the Microcosm, correspond to the processes included in the Lesser and Greater Mysteries, and are, in order, Baptism, Temptation, Passion, Burial, Resurrection, and Ascension; the "Marriage of the Lamb" being the equivalent of the Sabbath, or Within of the Cube, the Seventh, last and supremest of all the Acts of the Soul. The white stone, which, as we have seen, has been always the object of special veneration, is the wellknown symbol of the Divine Spirit, the nucleolus of the Cell, the sun of the system, the Head of the Pyramid. It was regarded as sacred to Venus, because she is the Genius / of the Fourth Day, the Revealer of the Sun and heavenly system, and to her, therefore, was peculiarly dedicated the emblem of Celestial Light. The Kaabeh is by its very name identified with the Kabbalistic Merkaba, the "car" in which the Lord God was said to descend to earth,-a phrase indicating the work of Manifestation, or Incarnation of Divine Being in "Creation." This Merkaba, or Vehicle of God, is described by Ezekiel as resembling a throne of sapphire, upon which is seated Adonai; and supporting and drawing it are four living creatures or cherubim, having four faces, the face of an ox, the face of a lion, the face of

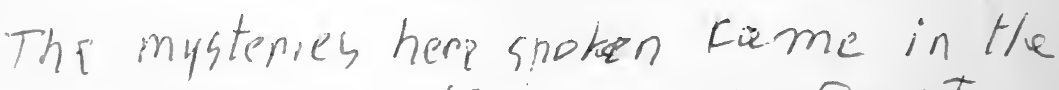


a man, and the face of an eagle. And there are also four wheels of the chariot, a wheel by each cherub, "in appearance like chrysolite." "And their whole body, and their necks, and their hands, and their wings, and the circles are full of eyes."

3. The perusal of this descriptive vision, which is identical with certain passages in the Apocalypse of St. John, was permitted only by the ancient Hebrews to men who had attained the age of thirty years. ${ }^{2}$ This age represents maturity, manhood, and reason, as reckoned in mystical numbers. Thus the Ark of Noë in which the Elect are preserved, is thirty cubits in height; the vision

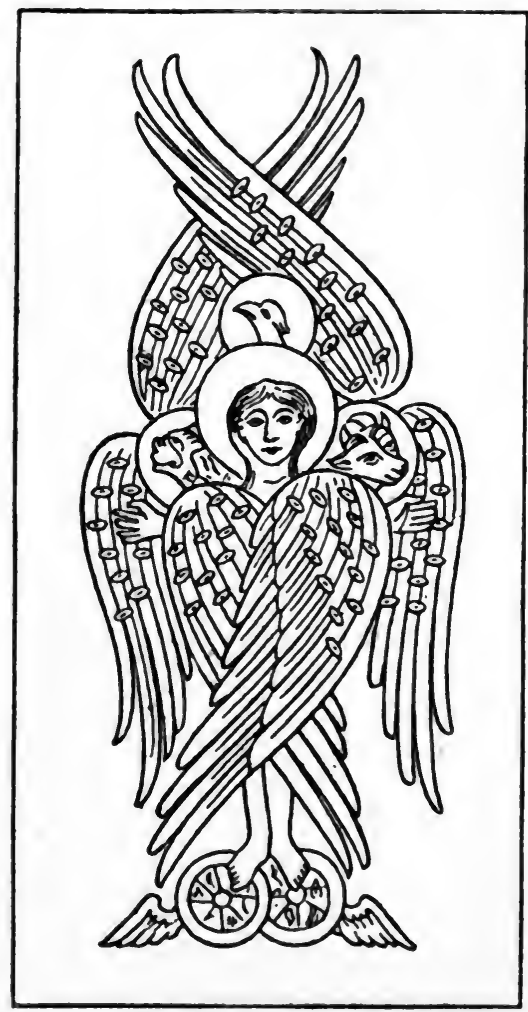

FIG. 1. - The Cherubim (Ezekiel and Apocalypse) representing-

1st. The Elemental Spirits of Macrocosm and Microcosm.

and. The Fourfold Human Kingdom. above cited occurs in his thirtieth year to Ezekiel, whose 
name signifies Strength of God; and Jesus, at the commencement of his mission of salvation, "begins to be about thirty years of age." Similarly the Kaabeh, or Cubic House of the Microcosm, is a cube of thirty feet.

4. This car, then,-within which Adonai rides,-typified by the Stone, called sapphire by Ezekiel, and jasper by St. John, is the Human Kingdom; and the living creatures which draw it are the four elements of that Kingdom, Body, Mind, Soul, and Spirit, corresponding respectively to the elemental spirits of Earth, Fire, Water, and Air, which constitute the Macrocosmic system. Of these living creatures the first in order, from without inwards, is the $\mathbf{O x}$, symbolising the earth or body, ploughed by the sacred Kine of Demeter, laborious and obedient; the next is the Lion, type of the magnetic or "fiery" mind, whose reason is destructive and whose energy is rapacious, the seat of daring and of the masculine will, which, suffered to expatiate uncontrolled, would rend and profane the sacred mysteries. Third in order comes the genius of the Soul, having a human face, and symbolising the true Person of the Microcosm, to whom, as to the Keeper of the House, belongs the constructive reason, the restraining and conservative force of the system. Last, and "over all the rest," is the Eagle, the bird of the Sun or Adonai, type of light, strength, and freedom, and of the wind on whose wings the Spirit rides. As it is written, "Behold, he shall come up as an eagle and fly." All these four cherubim are united in one, and make one fourfold creature, the wings of one being joined to the wings of another.

5. Over and around the seat or car of Adonai, as described by the seers of both Old and New Testaments, is a Rainbow, or Arch. This, the symbol of the Cup of the Heavens encircling and enclosing the Kosmos, is in the 
Scriptures termed Mount Sion and the Mount of the Lord; by the Hindûs it is called Mount Meru, and by the Greeks Olympus, the home of the Gods. And with all it is the symbol of the Celestial Kingdom, the Uncreate, which "was, and is, and is to come"; wherein dwell the Seven Spirits of Light, the Elohim of the Godhead. From this holy Mount proceed all the oracles and dispensations of Heaven, and nothing is done in the macrocosmic or microcosmic worlds that is not first conceived and perfect eternally in the divine counsel. "For ever, O Lord," says the psalmist, "Thy Word is written in Heaven." And for this reason the Scriptures declare that everything in the Tabernacle of the Wilderness was "made after the pattern of it in the holy Mount." For the Tabernacle in the Wilderness is, like the Kaabeh, a figure of the Human House of God, pitched in the wilderness of the material world, and removable from one place to another.

6. The Mystery implied in the vision of Ezekiel, is in Genesis presented under the hieroglyph of the Four Rivers which, flowing from one Source, go out to water Paradise. This source is in the holy place of the Upper Eden. It is the "well of the Water of Life," or God, Who is the Life and Substance of all things. And the four heads of the river have names corresponding to the zones of the fourfold unit of existence, as exemplified in the Cell, and therefore to the faces of the fourfold cherub.

Thus, Phison, the first stream, is the Ancient, or the Body and Matter, and represents the agricultural or mineral Earth, wherein lies gold, prosperity, and renown. The second river is Gehon, signifying the Vale of Gehenna or Purgation, the stream which traverses "Ethiopia" or Ath-opis, a compound word meaning literally the FireSerpent, or Astral Fluid. This river, therefore, is the 
igneous body or magnetic belt. The third river, which is Hiddekel, signifies the Double Tongue of Two Meanings, the strean which rises from and flows back to ancient or anterior ages, and which guides to Assyria, the land or place of Perfection. 'This river is the Soul, the permanent element in man, having neither beginning nor end, taking its origin in God anterior to time, and returning whence it came individuated and perfected. Divine in nature and human in experience, the language of the Soul is double, holding converse alike with heaven and earth. The fourth river is Euphrates, that is, the power of the Pharaoh,-or Phi-ourah, Voice of Heaven, the oracle and divine Will of the human system. And the "paradise" watered by these four rivers is the equilibrated human nature, the "garden which the Lord God has planted in Eden," or the Kosmos; that is, the Particular in the bosom of the Universal.

7. Not without deep meaning and design is the Book of Genesis or of Beginnings made to open with this description of the Four Rivers of Paradise. For their names and attributes supply the four wards of the Key wherewith to unlock all the mysteries of the Scriptures whose Prologue and Argument Genesis represents. These mysteries are, like the Rivers of Eden, distributed into four channels, each belonging to a distinct region of the fourfold human kingdom, whose queen and priestess is the Soul. And of these mystic or secret Scriptures, one of the most precious and profound is the Drama of the Fall, whose acts, depicted in the first chapters of the Bible, serve, as a series of hieroglyphic tableaux, to delineate at once the history of Man and the object of Religion.

8. Maimonides, the most learned of the Rabbis, speaking of the Book of Genesis, says, "We ought not to take 
literally that which is written in the story of the Creation, nor entertain the same ideas of it as are common with the vulgar. If it were otherwise, our ancient sages would not have taken so much pains to conceal the sense, and to keep before the eyes of the uninstructed the veil of allegory which conceals the truth it contains." In the same spirit it was observed by Jerome, that "the most difficult and obscure of the holy books contain as many secrets as they do words, concealing many things even under each word." "All the Fathers of the second century," says Mosheim, "attributed a hidden and mysterious sense to the words of Scripture." Papias, Justin Martyr, Irenæus, Clemens Alexandrinus, Gregory of Nazianzen, Gregory of Nyssa, and Ambrose, held that the Mosaic account of Creation and of the Fall was a series of allegories. The opinion of Origen on the same subject was plainly expressed. "What man," he asks, "is so simple as to believe that God, personifying a gardener, planted a garden in the East? that the tree of Life was a real tree which could be touched, and of which the fruit had the power of conferring immortality?"

9. It is hardly neccessary to enlarge on this point, or to bring forward further authorities. Suffice it to say that this interior method of interpreting sacred writings was, and still is, the method of all who possess the Gnosis, or secret knowledge of the mysteries, their mere letter being abandoned to the vulgar and to the "critics," as the husk or shell, which serves but to conceal, encase, and preserve the life-giving seed, the priceless pearl of the true "Word."

Io. Both the story of the Fall, and all cognate Myths or Parables, are far older and more universal than the ordinary unlearned reader of the Bible supposes. For 
the Bible itself, in its Hebrew form, is a comparatively recent compilation and adaptation of mysteries, the chief scenes of which were sculptured on temple walls, and written or painted on papyri, ages before the time of Moses. History tells us, moreover, that the Book of Genesis as it now stands, is the work, not even of Moses, but of Ezra or Esdras, who lived at the time of the Captivity,-between five and six hundred years before our era, -and that he recovered it and other writings by the process already described as Intuitional Memory. "My heart," he says "uttered understanding, and wisdom grew in my breast ; for the Spirit strengthened my memory." If then by such means he recovered what Moses had previously delivered orally to Israel, it is obvious that Esdras must have been initiated into the ancient tradition in a former state of existence; since no memory could have enabled him to recover that which he had never known, and which-when the Divine commission to rewrite it was given him--was so wholly lost that "no man knew any of the things that had been done in the world since the beginning." As the Talmud says, "Ezra could not have received the word, if Moses had not first declared it."

I I. Neither must it be supposed that we have the Books of Moses as recovered and edited by Esdras. The system of interpolation and alteration already referred to as largely applied to the Bible, especially affected the Pentateuch. And foremost amiong those who thus perverted it were the Pharisees, denounced in the New Testament, who greatly modified the text, introducing their own ritual into the law, incorporating with it their commentaries, and suppressing portions which condemned their doctrine and practice. According to Spinoza, "there was before the 
time of the Maccabees, no canon of holy writ extant; the books we now have were selected from among many others by and on the authority of the Pharisees of the second Temple, who also instituted the formulæ for the prayers used in the synagogue. ${ }^{3}$

12. Sacerdotal or rabbinical as were these interpolations and corruptions, they affected principally the books of ceremonial law and historical narrative, and referred to public customs, temple rites, priestly privileges, and questions of mere national interest. They hardly touched the great parabolic Myths which lie embedded in the Hebrew Scriptures like so many gems encased in clay. And gems these are, which, from prehistoric times, have been the property of the initiates of all religions, and especially of the Hindu and Egyptian, from which last indeed Moses originally drew them, as is occultly intimated when it is said : "And the children of Israel borrowed of the Egyptians jewels of silver and jewels of gold; and they spoiled the Egyptians."

13. With regard to this particular Myth of the Fall, the walls of ancient Thebes, Elephantine, Edfou, and Karnak bear evidence that long before Moses taught, and certainly ages before Esdras wrote, its acts and symbols were em. bodied in the religious ceremonials of the people, of whom, according to Manetho, Moses was himself a priest. And "the whole history of the fall of man is," as says Sharpe in a work on Egypt, "of Egyptian origin. The temptation of woman by the serpent and of man by the woman, the sacred tree of knowledge, the cherubs guarding with flaming swords the door of the Garden, the warfare declared between the woman and the serpent, may all be seen upon the Egyptian sculptured monuments."

${ }^{3}$ Tractatus Theologico-Politicus. 


\section{PART II.}

14. Let us now examine, in the order indicated by the hieroglyphic symbol of the Four Rivers, the significations of the mystic story to which it is prefixed.

Taking first the meaning corresponding to the river Phison or the Body, we have presented to us the condition of humanity in the perfect state, with special reference to the just and harmonious relations existing in that state between the Body and the Soul. This perfect condition is exemplified by a picture of the first Mystic Community, Lodge, or Church of men formed in the image of God, who, under the name of Sons of God, were distinguished from mere rudimentary men not made in the Divine image, - the still materialistic part of mankind.

This perfect condition was, and still is, reached-in the aggregate, as in the individual-by a process of evolution, or gradual unfoldment and growth from the lowest to the highest. They who first attained to this perfect state are celebrated by Ovid and others as the men of the "Golden Age," the primal Sabbath of the world under Saturn. This Age is reached, whether individually or collectively, whenever the Divine Spirit working within, has completed the generation of Man, making him spiritually "in the image of God, male and female." Such is the "Son of God" having power, because in him the soul dominates the body, and the body has no will of its own apart from that of the Divine Spirit.

15. In this aspect of the parable, then, "Adam" represents the bodily or sensuous nature in man; and his wife his psychic and spiritual nature. The epithet translated " help," " helper," or " helpmeet," applied to the woman, signifies an overseeing guide; and the name Isha, by 
which at first she is designated, denotes the generative substance, or feminine principle, of humanity. After the fall she is Chavah, or Eve, a term denoting the circle of life, and represented by a serpent. As the soul, she has two aspects, the earthly and the heavenly, and is indicated, therefore, by two kinds of serpent, the serpent of the dust, or tempter, and the serpent which represents the Divine Wisdom, or Sophia, -in which aspect she is man's initiator into divine knowledges. This heavenly serpent, the representative of the solar ray,--as opposed to the serpent of subterraneous fire,-is familiar to us under the name of "Seraph," the title given to angels of the highest order in the celestial hierarchy, and signifying "the burning,"--Sons of the Sun. In Egyptian symbology the Divine Seraph or Serpent appears constantly, surmounting a Cross and wearing the crown of Maut, the Mother, that is, the Living Mother, who is the original and celestial Reason. This is the Serpent on the Cross by looking to which, another sacred parable tells us, the Israelites were healed of the venomous bites inflicted on them by the Serpent of the Dust, the earthly and destructive reason whose figure is derived, not from the life-giving sun-ray, but from the flame of the devouring and rapacious fire. And thus it is said in the Gospel, that by the exhibition of this Divine Wisdom, by the restoration of the "Woman" or "Mother of the Living" to her rightful throne, will the world finally be redeemed from the dominion of the serpent of the Abyss, that is, of the lower and materialistic reason. "For as Moses lifted up the Serpent in the Wilderness, even so must the Son of Man be lifted up." For "Christ" is identical with Amun-Ra, "our Lord the Sun," offspring of the heavenly Maut. And the means of delivery for mankind from the "ravenous lion" and the "fiery serpents" of the 
outer intellect or earthly "wilderness of Sin " will be the exaltation of the Dual humanity at once "Mother "and "Son."

16. In the individual or microcosmic system, the celestial Wisdom or Soul of the Universe finds expression as the Soul of the Man. And the condition of humanity "unfallen "and sinless, is one of obedience on the part of the sense-nature, or "Adam," to the rule of the Soul, or "Eve." But, by the "Fall" this state of things is directly reversed, and the "woman" or the "Living" becomes subject to this sense-nature. This is "the Curse." And the curse will be removed, Paradise regained, and the second Sabbath of the Golden Age achieved, only when this "woman" is again invested with her rightful supremacy.

17. Eve is said to be taken from the side of the sleeping Adam, because, although the Soul subsists in all men, she becomes revealed only in such as have transcended the consciousness of the Body. When the "Adam" is asleep, passive, unassertive, the Soul, or Living man, is made manifest. Hers it is to guide, to rule, to command; hers the vocation of the Seer, the Pythoness, the Interpreter and Guardian of the Mysteries.

18. Tokens of the superior respect once accorded to the Soul, and to Woman as the soul's representative, abound in the historical remains of Egypt, where, as we learn from numberless sculptures, writings, and paintings, the goddess Isis held rank above her husband, the chief instructor in the Mysteries was represented as a woman, priestly and noble families traced their pedigree through the female line, and public acts and chronicles were dated by the name of the high priestess of the year.

19. Such then in the "Edenic" or unfallen state, are the mutual relations of Adam and Eve,-Sense and Soul. And the parable sets forth the end of the Edenic Sabbath, 
the ruin of the Golden Age, the "Fall" of the Church, as brought about by disobedience to the Divine Voice, or Central Spirit to which the Soul ought to be always dutiful. Sin thus originates with the Soul, as the responsible part of the man; and she whose office is to be to him overseer and guide, becomes his betrayer. The forbidden fruit communicated by the Soul to Adam, is the vital flame or Consciousness, described by classical poets as the "Fire of Heaven." For, as God is supreme and original Consciousness, the first manifestation of human consciousness has its seat in the Soul. In the pure, Edenic state, or, as it is called, the state of innocence, therefore, the shrine of this heavenly Fire is in the spiritual part of man. But Prometheus, or pseudo-thought, - the spurious thought as opposed to the true Hermetic Reason,-steals or "draws down" this Fire from its original place and transfers it to the outer man or body. Thenceforward, the consciousness of man ceases to reside in the soul, and takes up its abode in the body. That is to say, that man in his "fallen" condition is conscious only of the selfhood of the body, and until regenerate, or redeemed from the "Fall," he does not again become conscious and vitalised in the soul. To find the Soul is the first step towards finding Christ ; that is, as the Catholic Church puts it, "Mary brings us to Jesus." The materialistic unregenerate man is totally unconscious of his soul. He is aware only of the body, and his percipience of life is limited to the bodily sense. By the transference of the vitalising Fire from the "heaven" to the "earth" of the human system, the lower nature is inflamed and set at war with the Divine Spirit or "Zeus" within the man. This act is the Promethean Theft, punished so terribly by the "Father" at the hand of Hermes, the true Thought, or Angel of Understanding. For by this act, man becomes 
bound and fettered to the things of sense, the victim of a perverse will, which, as an insatiable bird of prey, continually rends and devours him. Thus is formulated that condition which Paul so graphically laments :- "I find then a law, that when I would do good, evil is present with me. For I delight in the law of God after the inward man; but I see another law in my members warring against the law of my mind, and bringing me into captivity to the law of sin which is in my members. $O$ wretched man; who shall deliver me from this body of death?"

20. Although, then, sin originates in the soul, the bodily nature is the ultimate offender. Hence it is to "Adam" that the interrogation is addressed:- " Hast thou eaten of the tree whereof I commanded thee that thou shouldest not eat?" And the penalty pronounced upon "Adam" enumerates the sorrows of the body in its "fallen" state, and foretells its inevitable return to the "dust" and "earth" of which it is;-a penalty, be it observed, which differs from that incurred by "Eve." For of her we read that her will, ceasing to polarise itself inwards and upwards upon her Divine Centre, is now, by the effect of the "Fall," directed outwards and downards towards her earthly mate. Like "Lot's Wife" in another and cognate parable, "she looks back, and straightway becomes a pillar of Salt." Salt was, in alchemic terminology, a synonym for Matter. This transformation into Salt is the converse of the "Great Work"; it is the Fixation of the Volatile. The Great Work is, in alchemic science, the Volatilisation of the Fixed. By this act of depolarisation the soul imprisons herself definitively in the body, and becomes its subject until that "Redemption" for which, says Paul, "all creation groans and travails in the pain of desire."

$2 \mathrm{r}$. In this first of the four explanations of our parable, 
the Tree of Life is the secret of Transmutation or of Eternal Life, of which it is impossible for the rebellious Adam to taste. For, so long as the elements of disorder remain in the body, so long as the flesh lusts against the spirit, so long as the Microcosm admits two diverse wills and is swayed by two adverse laws;-so long is the Fruit of this Tree unattainable. If it were possible for this ruined and disobedient Adam to "eat and live for ever," that eternal life would necessarily be the eternal hell of the Calvinists, that endless condition of torment and defiance of God, that life indestructible in the midst of destruction, which would -were it possible-constitute the division of the universe, and set up in opposition to the Divine rule, an equal and co-eternal throne of devildom.

22. As, in this reading of the myth, Adam represents the person, Eve the soul, and the Divine Voice the Spirit, so the serpent typifies the astral element or lower reason. For this subtle element is the intermediary between soul and body, the "fiery serpent" whose food is the "dust," that is, the perception of the senses, which are concerned with the things of time and matter only. This "serpent," if not controlled and dominated by the will of the Initiate leads the soul into bondage and perdition, by destroying the equilibrium of the system and dividing the Hearth-Fire. But though, when not thus dominated, the astral fire becomes, through its function of Tempter, the Destroyer and agent of Typhon or Negation, it is also, when under the dominion of the married spirit and soul, an element of power and a glass of vision.

23. The deposition from her rightful place of the Living Mother, Isha, Chavah, or Eve, typified by the celestial serpent, is then brought about by the seductions of the earthly and astral serpent. Thence ensues the ruin of the Edenic 
order. The soul is subject to the body, intuition to sense, the inner to the outer, the higher to the lower. Henceforth the monitions of the soul must be suppressed, her aspirations quenched, her conceptions difficult, her fruit quickened and brought forth with labour and sorrow. Intuition wars with passion, and every victory of the spiritual man is bought with anguish. And between the kabbalistic "woman" and the astral "serpent" there must be perpetual enmity; for henceforward the astral is antagonistic to the psychic, and between the intellectual and the intuitional "a great gulf is fixed." For this astral serpent is the terrene Fire, and the kabbalistic woman is the Water, the Maria, which is destined to quench it. "She shall crush his head, and he shall lie in wait for her heel."

Such is, on the plane historical, whether of the individual or of the Church, the meaning of "Paradise" and its "loss" - the gradual attainment of a certain high grade, and the decline therefrom; - a loss, the immediate effects of which manifest themselves in a subversion of the divine-natural order, and in the supremacy of the outer over the inner, the lower over the higher.

24. To humanity in Paradise, made in the divine Image, and unfallen, were given as meat the tree-fruits and the herb-grains; then, as Ovid tells us, "men were contented with the food which Nature freely bestowed." For the bodily appetites knew no law but that of a healthy natural intuition, and obeyed the impulse of the God within, desiring no other nourishment than that for which alone the body was anatomically and physiologically designed. But, so soon as it acquired a perverse, selfish will, a new lust arose; for a new and subhuman nature appeared in it, the nature of the beast of prey, whose image the fallen body has put on. That this is literal truth, all the poets, all the 
seers, all the regenerate testify, bearing witness also that Paradise can never be regained, Regeneration never completed, man never fully redeemed, until the body is brought under the law of Eden, and has cleansed itself thoroughly from the stain of blood. None will ever know the joys of Paradise who cannot live like Paradise-men; none will ever help to restore the Golden Age to the world who does not first restore it in himself. No man, being a shedder of blood, or an eater of flesh, ever touched the Central Secret of things, or laid hold of the Tree of Life. Hence it is written of the holy city: "Without are dogs." For the foot of the carnivorous beast cannot tread the golden floors; the lips polluted with blood may not pronounce the Divine Name. Never was spoken a truer word than this; and if we should speak no other, we should say all that man need know. For if he will but live the life of Eden, he shall find all its joys and its mysteries within his grasp. "He who will do the will of God, shall know of the doctrine." But until "father and mother" are forsaken,-that is, until the disciple is resolved to let no earthly affections or desires withhold him from entering the Perfect Way,-Christ will not be found nor Paradise regained. "Many indeed begin the rites," says Plato, "but few are fully purified." And a greater than Plato has warned us that "the Way is strait and the Gate narrow that leadeth unto Life, and few they are who find it." 4

\section{PART III.}

25. Coming next to the philosophical reading of our Parable, we find that on this plane the Man is the Mind or rational Intellect, out of which is evolved the Woman, the Affection or Heart ; that the Tree of Knowledge repre- See App. III. 
sents Maya or Illusion; the Serpent, the Will of the Body; the Tree of Life, the Divine Gnosis-or interior knowledge; and the sin which has brought and which brings ruin on mankind, Idolatry.

In this aspect of the Fall, we have presented to us the decline of Religion from the celestial to the astral. The affection of the unfallen mind is fixed on things above, spiritual and real, and not on things beneath, material and phantasmal. Idolatry is the adoration of the shadow instead of the substance, the setting up of the eidolon in the place of the God. It is thus no specific act, but the general tendency towards Matter and Sense, that constitutes the Fall. And of this tendency the world is full, for it is the "original sin" of every man born of the generation of "Adam"; and only that man is free of it who is "born again of the Spirit" and made "one with the Father," the central and divine Spirit of man's system.

26. Into this $\sin$ of Idolatry the human Heart declines by listening to the monitions and beguilements of the lower will, the will of the sensual nature. Withdrawing her desire from the Tree of Life,-the Gnosis-the Affection fixes on the false and deceitful apples of Illusion, pleasant and desirable "to the eyes" or outer senses. "Your eyes shall be opened," urges the lower will, "and you shall be as gods, knowing both worlds." The Affection yields to the seductions of this promise, she entangles herself in Illusion, she communicates the poison to the Mind, and all is lost. Man knows indeed, but the knowledge he has gained is that of his own shame and nakedness. "Their eyes were opened, and they knew - that they were naked." By this act of idolatry man becomes instantly aware of the body, of sense, of Matter, of appearance; he falls into another and a lower world, precipitated headlong by that fatal step out- 
wards from the celestial to the astral and terrene. Henceforth the fruit of the divine Gnosis, the healing Tree, is not for him, he has lost the faculty of discerning Substance and Reality, the eye of the Spirit is closed, and that of Sense is opened; he is immersed in delusion and shadow, and the glamour of Maya. Sudden divorce has taken place in him between the spirit and the soul. $\mathrm{He}$ has lost the "Kingdom, the Power and the Glory." And, so long as he remains in the "wilderness" of the illusory world, the Gnosis is guarded against him by the Elemental Spirits and their fourfold sword, which, to the man having lost both the power and the secret of the Dissolvent, are an impenetrable barrier.

27. We now enter on the Ethical and Psychic interpretation of the myth, which interpretation is itself of a dual character, affecting on the one hand the Church, on the other the Individual.

In this third aspect of the parable the Man represents the human Reason; the Woman, Faith, or the religious Conscience; the Serpent, the lower nature; the Tree of Knowledge, the kingdom of this world; and the Tree of Life the kingdom of God. The religious Conscience set over the human Reason as his guide, overseer, and ruler, whether in the general, as the Church, or in the particular, as the Individual, falls when-listening to the suggestions of the lower nature-she desires, seeks, and at length defiles herself with the ambitions, vanities, and falsehoods of the kingdom of this present world. Nor does she fall alone. For, ceasing to be a trustworthy guide, she becomes herself serpent and seducer to the human Reason, leading him into false paths, betraying and deluding him at every turn, until, if she have her way, she will end by plunging him into the lowest depths of abject ignorance, foolishness, and weak- 
ness, there to be devoured by the brood of Unreason, and annihilated for ever. For she is now no longer the true wife Faith, she is become the wanton, Superstition; and rather than heed or obey monitions such as hers, he must, if he would save himself, assert dominion over her and keep her in bondage and subjection to his authority. Better far that he should be master in the Man, than superstition, whose method is folly, whose end is madness and death.

28. The Church at her best, unfallen, is the glass to the lamp of Truth, guarding the sacred flame within, and transmitting unimpaired to her children the light received upon its inner surface. Such is the function of the priesthood, in idea and intention; but not, now at least, in fact and deed. For through the failure of the priesthood to resist the materialising influences of the world upon the side exposed to the world, the lamp-glass has become so clouded that the light within is either unable to pass through it at all, or passes only to cast around, instead of genial rays, ghastly and misleading shadows. Or, may-be, the light has expired altogether; and, not the maintenance of the flame, but the concealment of its loss, is become the prime object of solicitude for its whilom guardians.

29. The world's history shows that hitherto this Fall has been the common fate of all Churches. Nor is its cause far to seek, seeing that all human histories are essentially one and the same, whether the subject be an individual or an aggregation of individuals. A Church is, like every other personal organism, a compound organism. Between the circumferential containing body, and the central informing spirit,- - having a side turned to each, and uniting the mental with the spiritual,-stands the soul, to which the Church, Priesthood, or Intuition corresponds, in order by her mediation to reconcile the world to God and main- 
tain the Man in grace. And so long as, by virtue of the purity of such medium, the stream of life and light from the central spirit of Truth is enabled to find free course and circulation, perfect health continues in the system. But when, inclining towards the outer and lower elements, the Church abandons the inner and higher, and becomes of the earth earthy, the flame within her shrine, choked and quenched, departs, leaving the sanctuary tenantless. Then, no longer of the heavenly, but of the earthly kingdom, the fallen Church becomes the betrayer and the enemy of man. To confess the truth - that she has suffered the sacred flame to expire-would, in respect of all for which she is now solicitous, - her material sway and interests,- be fatal. Hence the fact that she is naked and empty must be studiously concealed, and all approach forbidden, that no one not concerned to keep the secret may spy upon her darkened shrine. Thenceforth the Church stands between God and the people, not to bring them together, but to keep them apart. With light and spirit lost to view, and the way to the kingdom of God blocked by superstition, the rational man either ceases to believe that any such kingdom subsists, and, falling in his turn, he plunges into the gulf of atheism or agnosticism; or, withheld by his traitor spouse from attaining the fruition of the Tree of Life, contents himself with "stones for bread," and with "serpents" of the astral in place of the true celestial mysteries.

30. Thus fallen and degraded, the Church becomes, as mankind too well knows, a Church "of this world," greedy of worldly dignities, emoluments, and dominion, intent on foisting on the belief of her votaries, in the name of authority and orthodoxy, fables and worse than fables, apples of Sodom and Gomorrah, Dead-sea fruit; - a Church jealous 
of "the Letter which killeth"; ignorant of, or bitterly at enmity with, "the Spirit which giveth life."

\section{PART IV.}

3r. We now reach the last and innermost interpretation of our fourfold hieroglyph, the spiritual and creative secret embodied in the Edenic allegory. This secret is sometimes more obscurely alluded to as the Lapse of heavenly beings from their first happy estate into sub-celestial spheres, and their final redemption by means of penance done through incarnation in the flesh. It need scarcely be said that this imagined Lapse is also a parable designed to veil and preserve a truth. And in its interpretation is found the creative secret, the projection of Spirit into Matter; the Fall or Descent of Substance into Maya or Illusion. Hence results Chavah, the Eve of Genesis, and circle of life conditioned as past, present, and future, and corresponding to Jehovah, the covenant name of Deity. In this reading of the parable, the Tree of Divination or Knowledge becomes Motion, or the Kalpa, - the period of Existence as distinguished from Being; the Tree of Life is Rest, or the Sabbath, the Nirvâna; Adam is Manifestation; the Serpent-no longer of the lower but of the higher sphere-is the celestial Serpent or Seraph of heavenly Counsel. For now the whole signification of the myth is changed, and the Act of Archë, the Woman, is the Divine act of Creation. Ase, the root of the Hebrew word for Woman, signifies the generating female Fire, the Living Substance producing or causing production. Its Coptic form, Est, gives Esta or Hestia, the goddess of the Temple-fire, for the continual preservation of which the order of Vestal virgins was established. This word, Est, 
is identical also with the Latin and Greek equivalents of IS, whence are derived all the modern European forms of the same affirmative, as also the names Esther and Easter.

32. Adam signifies the Red, hence the Blood; and in Blood, Substance becomes incarnate and takes form as Nature or Isis, which name is, of course, but another rendering of the affirmative EST. Hence Nature, the incarnate Archë, is said to be born from the side of Adam, or Manifestation by Blood. "Blood," as says "Eliphas Levi," "is the first incarnation of the Universal Fluid; it is the materialised vital Light. It lives only by perpetually transforming itself, for it is the universal Proteus, the great Arcanum of Life."

33. Now, as has been said in a former discourse, Motion is the means by which Spirit becomes visible as Matter, for Spirit and Matter represent two conditions of one thing. Therefore by the Tree of Divination of Good and Evil, in this interpretation, must be understood that condition by means of which Spirit, projected into appearance, becomes manifested under the veil of Maya.

34. Among the sacred symbols and insignia of the Gods depicted in Egyptian sculpture, none is repeated so often as the Sphere. This Sphere is the emblem of Creative Motion, because the Manifesting Force is rotatory; being, in fact, the "Wheel of the Spirit of Life" describer by Ezekiel as "a wheel within a wheel," inasmuch as the whole system of the universe, from the planet to its ultimate particle, revolves in the same manner. And for this reason, and as an evidence of the knowledge which dictated the ancient symbology of the Catholic Church, the Eucharistic Wafer, figure of the Word made Flesh, is circular. The sacramental sphere, poised on the head of a Serpent or Seraph, is a 
common hieroglyph in Egyptian sacred tableaux; and sculptures bordered with processions of such emblematic figures are frequent in the ancient temples. The Apple, or round Fruit of the Tree of the Kalpa, - of which, by the advice of the "Serpent" of heavenly counsel, the Divine Archë partakes, and thereby brings about the "Fall" or Manifestation of Spirit in Matter,-is no other than the Sacramental Host, type of the Bread of Life or Body of God, figured in the Orb of the Sun, reflected in the disc of every star, planet, and molecule, and elevated for adoration on the Monstrance of the universe.

35. Only when the Naros, or cycle of the Six Days, shall again reach their Seventh Day, will "the Lord of the Seventh"-whom the Latins adored with unveiled heads under the name of Septimianus - return, and the veil of Illusion or Maya be taken away. The anticipation of the Seventh Day of the renewed Arcadia, the Seven Days' festival of liberty and peace, was held by the Greeks under the name of the Kronia, and by the Latins under that of the Saturnalia. This redemptive Sabbath is spoken of in the Gospel as the "harvest of the end of the world," when Saturn or Sator (the Sower) as "Lord of the Harvest," "shall return again with joy, bringing his sheaves with him." And when that Day comes, the Fruit of the Tree of Life, or Nirvâna, shall be given for the healing of the universe; rest from motion shall put an end to Matter ; and Substance, now by the "Fall" brought under the dominion of Adam or Manifestation, shall return to $\mathrm{Her}$ original divine estate.

36. It remains only to speak of the symbolic Bow or Cup encircling the microcosmic car of Adonai, and representing, as already explained, the heavenly Mount, of which the phenomenal heaven is the transcript. The planisphere 
of the heavens, familiar in all ancient astrological science, is divided into two parts by a line passing from east to west, and representing the horizon. The portion of the planisphere below this horizontal line comprises the lower and invisible hemisphere; that which is above, the upper and visible. At the opening of the year the constellation of the Celestial Virgin, Astræa, Isis, or Ceres, is in ascension. She has beneath her feet in the lower horizon the sign Python or Typhon, the Dragon of the Tree of the Hesperides, who rises after her, pursuing her, and aiming his fangs at her heel.

37. This heavenly Virgin is the regenerate Eva, Maria the Immaculate, the Mother of the Sun-God. Her first "decan" is that of the Sun, whose birth as Mithras was celebrated on the twenty-fifth day of December, - the true birth of the year, -at midnight, at which time she appears above the visible horizon. The figure of the sun was consequently placed over this "decan" on the planispheric chart, and rests therefore on the head of the Virgin, while the first "decan" of Libra, which is that of the Moon, is under her feet. In her we recognise the woman of the Apocalypse, victorious over her adversary the Dragon, and restoring by her manifestation the equilibrium-Libra-of the universe.

38. Thus the Heavens eternally witness to the promise of the final redemption of the Earth, and of the return of the Golden Age, and the Restoration of Eden. And the keynote of that desired harmony is to be found in the exaltation on all the universal fourfold planes, physical, philosophical, psychic, and celestial, of the Woman.

Once again, in the end as in the beginning, shall the Soul rehabilitated, the Affection regenerated, the Intuition puri- 
fied, the Divine Substance redeemed from Matter, be throned, crowned, and glorified.

39. That the time of the rising of this Celestial Virgin and of the rehabilitation of truth by the Woman-Messias of the Interpretation is near at hand, they who watch the "times" and the "heavens" may know by more than one token. To name but one. The sign Leo, which upon the celestial chart precedes the ascension of the Woman, going before her as her herald, is the sign of the present Head of the Catholic Church. When assuming that title, he declared his office to be that of the "Lion of the Tribe of Juda," the domicile of the Sun, the tribe appointed to produce the Christ. To the ascension of this constellation, preparing, as it were, the Way of the Divine Virgin, the prophecy of Israel in Genesis refers :-

"Juda is a strong lion; my son, thou art gone up. The sceptre shall not be taken away from Juda till the coming of the Messenger-or Shiloh-the expectation of the nations."

And not only does the chief Bishop of the Church bear this significant name of the "Lion," but he is also the thirteenth of that name, and Thirteen is the number of the Woman and of the lunar cycle, the number of Isis and of the Microcosm. It is the number which indicates the fulness of all things, and the consummation of the "Divine Marriage," the At-one-ment of Man and God. ${ }^{5}$

Moreover the Arms of Leo XIII. represent a Tree on a Mount, between two triune Lilies, and in the dexter chief point a blazing Star; with the motto "Lumen in Colo." What is this tree but the Tree of Life; these

5 When, on the death of Pius IX. in 1878, Cardinal Pecci was elected Pope, he assumed the name of Leo, and became Leo XIII. He died in 1903. 
Lilies but the Lilies of the new Annunciation, - of the Ave which is to reverse the curse of Eva? What star is this, if not the Star of the second Advent? History repeats itself only because all history is already written in "heaven."

40. For the signs of the Zodiac, or of the "Wheel of Life," as the name signifies, are not arbitrary, they are the Words of God traced on the planisphere by the finger of God, and first expressed in intelligible hieroglyphs by men of the "Age of Saturn," who knew the truth, and held the Key of the Mysteries. The Wheel of the Zodiac thus constituted the earliest Bible; for on it is traced the universal history of the whole Humanity. It is a mirror at once of Past, Present, and Future; for these three are but modes of the Eternal NOW, which, philosophically, is the only tense. And its twelve signs are the twelve Gates of the heavenly City of religious science, the Kingdom of God the Father.

4I. The philosophy of the day, unable, through its ignorance of the soul, to solve the riddle of the Zodiac, concludes that all sacred history is a mere tissue of fables, framed in accordance with the accidental forms of the constellations. But, as the Initiate knows, these signs are written on the starry chart because they represent eternal verities in the experience of the soul. They are the processes or acts of the soul, under individuation in Man. And so far from being ascribed to Man because written in the Zodiac, they were written in the Zodiac because recognised as occurring in humanity. In the Divine order, pictures precede written words as the expressions of ideas. The planisphere of the Zodiac is thus a picture-bible; and the images embodied in it have controlled the expression of all written Revelation. 


\section{PART V.}

42. This discourse was closed for the writer by a vision, an account of which will form an equally fitting conclusion for the reader. ${ }^{6}$ This vision was as follows :-

A golden chalice, like those used in Catholic rites, but having three linings, was given to me by an Angel. These linings, he told me, signified the three degrees of the heavens,-purity of life, purity of heart, and purity of doctrine. Immediately afterwards, there appeared a great dome-covered temple, Moslem in style, and on the threshold of it a tall Angel clad in linen, who with an air of command was directing a party of men engaged in destroying and throwing into the street numerous crucifixes, bibles, prayer-books, altar-utensils, and other sacred emblems. As I stood watching, somewhat scandalised at the apparent sacrilege, a Voice at a great height in the air cried with startling distinctness, "All the idols He shall utterly destroy!" Then the same Voice, seeming to ascend still higher, cried to me, "Come hither and see!" Immediately it appeared to me that I was lifted up by my hair and carried above the earth. And suddenly there arose in mid-air the apparition of a man of majestic aspect, in an antique garb, and surrounded by a throng of prostrate worshippers. At first the appearance of this figure was strange to me; but while I looked intently at it, a change came over the face and dress, and I thought I recognised Buddha,- - the Messiah of

6 Edward Maitland said : "It was more than a vision. It was a drama actually enacted by her [A. K.] in sleep, wherein she was withdrawn from the body for the purpose, thus making it real for the plane on which it occurred. The excitement of it was so intense that some days passed before her system fully recovered its normal state. We regarded it as a veritable annunciation to her of the redemptive work to be accomplished through her" (Life of $A . K$., vol. ii., p. 20) 
India. But scarcely had I convinced myself of this, when a great Voice, like a thousand voices shouting in unison, cried to the worshippers: "Stand upright on your feet :Worship God only!" And again the figure changed, as though a cloud had passed before it, and now it seemed to assume the shape of Jesus. Again I saw the kneeling adorers, and again the mighty Voice cried, "Arise! Worship God only!" The sound of this Voice was like thunder, and I noted that it had seven echoes. Seven times the cry reverberated, ascending with each utterance, as though mounting from sphere to sphere. Then suddenly I fell through the air, as though a hand had been withdrawn from sustaining me : and again touching the earth, I stood within the temple I had seen in the first part of my vision. At its east end was a great altar, from above and behind which came faintly a white and beautiful Light, the radiance of which was arrested and obscured by a dark curtain suspended from the dome before the altar. And the body of the temple, which, but for the curtain, would have been fully illumined, was plunged in gloom, broken only by the fitful gleams of a few half-expiring oil-lamps, hanging here and there from the vast cupola. At the right of the altar stood the same tall Angel I had before seen on the temple threshold, holding in his hand a smoking censer. Then, observing that he was looking earnestly at me, I said to him: "Tell me, what curtain is this before the Light, and why is the temple in darkness?" And he answered, "This veil is not One, but Three; and the Three are Blood, Idolatry, and the Curse of Eve. And to you it is given to withdraw them. Be faithful and courageous; the time has come." Now the first curtain was red, and very heavy; and with a great effort I drew it aside, and said, "I have put away the veil of blood from before Thy Face. Shine, 
O Lord God!" But a Voice from behind the folds of the two remaining coverings answered me, "I cannot shine, because of the idols." - And lo, before me a curtain of many colours, woven about with all manner of images, crucifixes, madonnas, Old and New Testaments, prayer-books, and other religious symbols, some strange and hideous like the idols of China and Japan, some beautiful like those of the Greeks and Christians. And the weight of the curtain was like lead, for it was thick with gold and silver embroideries. But with both hands I tore it away, and cried, "I have put away the idols from before Thy Face. Shine, O Lord God!" And now the Light was clearer and brighter. But yet before me hung a third veil, all of black; and upon it was traced in outline the figure of four Lilies on a single stem inverted, their cups opening downwards. And from behind this veil, the Voice answered me again, "I cannot shine, because of the curse of Eve." Then I put forth all my strength, and with a great will rent away the curtain, crying, "I have put away her curse from before Thee. Shine, O Lord God!"

And there was no more a veil, but a landscape, more glorious and perfect than words can paint, a Garden of absolute beauty, filled with trees of palm, and olive, and fig, rivers of clear water and lawns of tender green; and distant groves and forests framed about by mountains crowned with snow; and on the brow of their shining peaks a rising Sun, whose light it was I had seen behind the veils. And about the Sun, in mid-air hung white misty shapes of great Angels, as clouds at morning float above the place of dawn. And beneath, under a mighty tree of cedar, stood a white elephant, bearing in his golden houdah a beautiful woman robed as a queen, and wearing a crown. But while I looked, entranced, and longing to 
look for ever, the garden, the altar, and the temple were carried up from me into Heaven. Then as I stood gazing upwards, came again the Voice, at first high in the air, but falling earthwards as I listened. And behold, before me appeared the white pinnacle of a minaret, and around and beneath it the sky was all gold and red with the glory of the rising Sun. And I perceived that now the voice was that of a solitary Muezzin standing on the minaret with uplifted hands and crying :-

"Put away Blood from among you !

Destroy your Idols !

Restore your Queen!"

And straightway a Voice, like that of an infinite multitude, coming as though from above and around and beneath my feet, - a Voice like a wind rising upwards from caverns under the hills to their loftiest far-off heights among the stars,- - responded,-

"Worship God alone !" 7

7 See C.W.S., part i., No. ii. (2), p. 8. 


\title{
LECTURE THE SEVENTH.1
}

\author{
THE FALL (No. II.).
}

PART I.

I. OUR subject is again the cataclysmal event mystically called the Fall of Man. Before entering upon it, we will recapitulate briefly what has been said respecting the nature of man. As already explained, this is fourfold. This fourfold nature is itself included in a dual personality. Consisting of male and female, Reason and Intuition, Man is, in this sense, a twofold being. But the masculine moiety comprises the dualism of Sense and Intellect; and the feminine moiety, the dualism of Soul and Perception.

2. Owing to this duality of his constitution, every doctrine relating to Man has, primarily, a dual significance and application. And owing to his fourfoldness, it has also, secondarily, a fourfold significance and application. The interpretation, therefore, of any doctrine must, to be complete, be at the least twofold. And since there is between the inner and outer spheres of man's being an exact correspondence, by virtue of which, whatever subsists or occurs in the one sphere has its counterpart in the other, the terms which describe the one apply also to the other;

1 This lecture was written by Edward Maitland, with the exception of the italicised portion of paragraph 3 , which is adapted from an Illumination of Anna Kingsford, as also is the whole of Part II., and

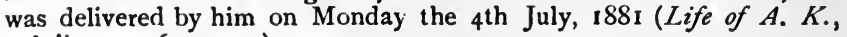
vol. ii., pp. 16, 17, 32). 
and no interpretation or application is complete which may not include both spheres.

3. Thus it comes-to quote a fragment of Hermetic derivation - that :-

"All Scriptures which are the true Word of God, have a dual interpretation, the Intellectual and the Intuitional, the Apparent and the Hidden.

"For nothing can come forth from God save that which is fruitful.

"As is the nature of God, so is the Word of God's Mouth.

"The Letter alone is barren; the Spirit and the Letter give Life.

"But that Scripture is the more excellent which is exceeding fruitful, and brings forth abundant signification.

"For God is able to say many things in one; as the perfect Ovary contains many seeds in its Chalice.

"Therefore there are in the Scriptures of God's Word, certain Writings which, as richly yielding Trees, bear more abundantly than others in the self-same holy Garden.

"And one of the most excellent is the Parable of the Fall, which, as a stream parted into four branches, has a fourfold head, and is a word exceeding rich." 2

For a parable it is, and not a history, as ordinarily understood, but having a hidden, that is, a mystic meaning; - a parable, moreover, which, while founded indeed upon a particular fact, is true for all time, in that it is perpetually being enacted. Being thus, the Parable of the Fall constitutes an Eternal Verity.

4. The opening chapters of the sacred books exhibit, then, not merely events occurring in, and having relation to, a particular place or time, but the meaning and object of religion at large, the creation of man, the nature of sin, ${ }^{2}$ See $C$ W.S., part ii., No. iii., p. 220. 
and the method of salvation; and all these as perpetually subsisting. These chapters constitute thus a kind of argument or abstract prefixed to the divine drama of man's spiritual history. And the key to their interpretation is the word NOW.

5. For, in the Divine Mind, there is no past, in the Divine economy, no future. God is I AM, and always IS. The term Jehovah combines in one word the tenses past, present, and future of the verb I AM. Scripture is a record of that which is always taking place. Thus, the Spirit of God, which is original Life, is always moving upon the face of the waters, or heavenly deep, which is original Substance. And the One, which consists of these two, is always putting forth alike the Macrocosm of the universe and the Microcosm of the individual, and is always making man in the image of God, and placing him in a garden of innocence and perfection, the garden of his own unsophisticated nature. And man is always falling away from that image and quitting that garden for the wilderness of sin, being tempted by the serpent of sense, his own lower element. And from this condition and its consequences he is always being redeemed by the blood of the sacrifice always being made for him by the Christ Jesus, who is Son at once of God and of man, and is always being born of a pure virgin ;-dying, rising, and ascending into heaven.

6. For these are, one and all, mystic terms denoting facts of perpetual recurrence in the history of the Soul, and necessary to salvation It depends, however, upon the sense in which they are understood, whether they minister to salvation or to condemnation. The letter, it is declared, killeth; the letter and the spirit together have and confer life. For, while interpreted in one sense-the sense of the spirit-they are divine truths; interpreted in another sense 
- the sense of the letter-they are idolatrous falsehoods. And inasmuch as idolatry consists in the materialisation of spiritual mysteries, and the substitution for the true things signified, of their material symbols ; those interpretations are idolatrous which give to mystical doctrines physical applications. Now, all Scripture given by inspiration of God is mystical ; and, in its esoteric sense, deals not with material things, but with spiritual realities, the mystic intention of the things named being alone implied, and by no means the things themselves. And this rule holds good alike of those two divisions of Scripture which are called respectively the Old and the New Testament.

7. In accordance, then, with the fourfold constitution of existence, the Parable of the Fall has a fourfold signification. But, inasmuch as that which is true of the race is true also of the individual, and that which is true of the individual is true also of the race, each portion of the fourfold signification has a twofold application, namely, to the race and to the individual. For each alike it is true on the planes spiritual, moral, intellectual, and physical. And it is constructed in terms derived from this last, because only thus it can find on any plane universal recognition; since the physical is the universal mirror of the unmanifest, and is the only medium capable of reflecting at once all the three planes above itself. Thus represented in terms derived from the physical, it possesses a meaning for all, if only as an allegory of the Seasons, forhaving an astronomical basis-such it also is.

8. So far, however, from being intended to represent the actual natural history, either of the planet or of man, or to be what now-a-days it is the fashion to call scientific, it is so contrived as to make that history appear to be the reverse of what it really is. For, read by the super- 
ficial sense, it represents man as created perfect from the first, by a power working from without; whereas, the truth is, that he is created by gradual development from rudimentary being, by a power-the Divine Spirit-working from within. For this is ever the method of the Divine procedure, and it is this that the parable really implies.

9. But only when it is understood what the mystic books mean by Man, does the true meaning appear. And as, until this is understood, it is vain to attempt to interpret those books, a definition of the term Man, as therein employed, must be our first concern.

A materialistic science, discerning only the outward appearance of things, and taking, therefore, no account of qualities, necessarily makes the Form all. Hence, for it, man is but a primate among the animals, and sufficiently defined under the terms Mammal, Biped, Bimanous, and the like. The notion that the form, to be valid, must be filled up, and that he who is man in form only, and is devoid of all the qualities, intellectual, moral, and spiritual, which are comprised in the term humanity, is not really man, is a notion which does not enter into the conception of the Materialist.

ro. According to mystical doctrine, on the other hand, he who is human in form only, is but man rudimentary, and to be classed, in all essential respects, with those lower grades of humanity, the plants and animals. He has, like them, the potentiality only of humanity, and is no realised humanity. For, according to this doctrine, man's supreme function is knowledge; so that he is not man until he knows, or, at least, has found his organon of knowledge, and is capable of knowing. Besides, the very term knowledge has, in this relation, a special meaning. For the 
mystic applies it only to the cognition which is of Realities. That alone for him is knowledge, which has for its subject the nature of Being, his own nature, that is, and God's ; not phenomena merely, but Substance, and its method of operation. And, forasmuch as, in order to have this knowledge, a man must have attained his spiritual consciousness, it follows that, according to mystical definition, man is not man until he has attained the consciousness of his spiritual nature. To attain this consciousness, and this alone, is to attain true manhood. And, prior to the attainment of this, the individual is but as an infant, incompetent to fulfil, or even to comprehend, the functions of manhood.

I I. The reason of this is, that man is a dual being, not masculine only or feminine only, but both of these; not man only or woman only, but man and woman. And he is this in respect, not of his exterior and physical, but of his interior and spiritual nature. For, since humanity is dual, that which, being man, represents humanity, must be dual also. And this cannot be on the plane merely physical, whereon but one moiety only of the human dualism can be expressed in the same individual. On this plane it takes two persons, a man and a woman, to express the whole humanity. And it is by means of its two sexes that the body constitutes a symbol of the humanity which, in being interior and permanent, is alone the humanity which is real.

12. For,-as already stated,-that whereby the man attains to manhood is woman. It is his power to recognise, appreciate, and appropriate her, that stamps him, physically, man. She it is who, influencing him through the affections kindled by her in him, withdraws him from his outward and aimless course, in which, left to himself, he would sooner or later be dissipated and lost; and 
who, gathering him round herself as centre, redeems him and makes him into a system capable of self-perpetuation, supplementing and complementing meanwhile his masculine qualities, as will, force, and intellect, with her feminine qualities, as endurance, love, and intuition. Thus, by the addition of herself she makes him Man. It is not to the male moiety of the dualism constituted by them, that the term Man is, properly, applicable, any more than to the female moiety. Neither of them separately is Man ; and it is by an unfortunate defect of language that the masculine half of man is called a man. ${ }^{3} \mathrm{He}$ is man male, as she is man female. And only when wedded, that is zvelded, into one by a perfect marriage, does Man result, the two together thus blended making one humanity, -as earth and water make one Earth,-and by their power of self-perpetuation and multiplication demonstrating the completeness and perfection of their system.

13. Only because it is already so with Humanity on the inner plane, is it so on the outer. Whatever the sex of the person physically, each individual is a dualism, consisting of exterior and interior, manifested personality and essential individuality, body and soul, which are to each other masculine and feminine, man and woman; he the without, and she the within. And all that the woman, on the planes physical and social, is to the man, that she is also on the

3 Much and serious misconception has arisen from the use of the same term to denote both the whole humanity and the masculine half of humanity. The confusion is identical with that which arises from the use of the word Earth to denote both the entire globe of earth and water, and the solid portion only of the globe. As in its former sense earth and water are equally Earth, the one being as earth masculine, and the other as earth feminine, so man and woman are equally Man, the one being man masculine, and the other man feminine. For her as well as for him, the exterior personality is what mystically is called the "man," and the interior being is the "woman." 
planes intellectual and spiritual. For, as Soul and Intuition of Spirit, she withdraws him, physically and mentally, from dissipation and perdition in the outer and material ; and by centralising and substantialising him redeems and crowns him ;-from a phantom converting him into an entity, from a mortal into an immortal, from a man into a god. Without her, it were better both for himself and for others that he should not be at all. On no plane of being is it good that the man-element be alone. For without Love, Force can but work evil until it be spent. And such is man and his doom until he finds and is found of her, the soul and woman within him. She is to him very "mother of the living," and without her is no life. And she is this because she is, by her nature, that wherein the Divine Life resides. For, as the soul is the life of the man, so is the spirit, which is God, the life of the soul. Thus is she mediator between man and God, to draw them together in herself. And only he is truly alive, is truly Man, and made after the Divine Image, in whom she thus operates. Redeeming him from chaos and making him a Kosmos, she is the centripetal to his centrifugal, the attractive to his separative, the constructive to his destructive, the synthesis to his analysis, the being to his seeming, the reality to his illusory. With her advent he begins to be; and thenceforth, through her, he can clain kindred with the I AM.

14. Man, then, in our parable, is represented as created perfect in that he is, in the mystical sense, male and female, that is, he has a soul-anima divina-superadded to his exterior personality-anima bruta,-each of which is conscious of the separate existence of each. Their attainment of this consciousness is represented under the allegory of the creation of the woman; they first then begin to exist for each other. The time chosen for the attainment of 
this stage in their history, is an important element in the process. For it is the same for all men. It is not while engaged in the active exercise of his masculine qualities that man first becomes conscious of his other and better, because interior and divine, self. His aggressive and destructive tendencies must have been exhausted, and the animal in him, his own exterior self,-in a word, the man part of him,-cast into deep slumber, before the woman in him can reveal herself, and make him conscious of something, or rather some one, within him,--himself, yet differing from himself, and higher and better than anything he has before had or been.

15. Once recognised, and her reality and superiority admitted, there is no height of goodness and knowledge to which she cannot raise him, if but only he follow her lead, and keep her free from defilement by Matter and Sense, the direct traffic with which appertains to him. In order properly to fulfil her function in regard to the man, and attract his regards upwards to her, she must herself aspire continually to the Divine Spirit within her, the central sun of herself, as she is that of the man. If, withdrawing her gaze from this, she fix it on things without and below, she falls, and in her fall takes him with her. Except through her, he cannot fall ; for only through her does he at all rise, being, by his very nature the lowermost, and of himself incapable of rising. For he rests on the material plane, and is of earth earthy.

16. It is not because Matter is in itself evil that the soul's descent into it constitutes a fall and ensures disaster. It is because to the soul, Matter is a forbidden thing. So that the act constitutes a disobedience. The prohibition, however, is not an arbitrary one, but is founded in the soul's own nature, as also is the penalty attached to her trans- 
gression. Only by remaining spiritual substance can soul subsist as soul, having all the potentialities of soul. By quitting her own proper condition and descending into Matter, she takes upon herself the limitations of Matter. As between Spirit and Matter there is no boundary line, it is only by the maintenance of a will set exclusively spiritwards, that a soul can be held from subsiding into the lower condition of Matter, finally to disintegrate and perish.

17. Such a fall, it will be well to repeat, does not involve the loss of any portion of the divine Substance. The animating spirit is withdrawn, and the constituent elements are separated. That only which perishes is the individuality constituted of these. And it perishes through its own persistent refusal of that "Gift of God" which is Eternal Life, the gift, namely, of a portion of God's Self or Spirit. Refusing this, man refuses life, as he is free to do. God rejects and annihilates no one. Man, by his rejection of God, annihilates his own individuality. And God cannot make man on any other terms. And this, for the reason that God is omnipotent. God would not be omnipotent were the individual indestructible. For then there would be something not God, possessing all the power of God. So that, instead of this doctrine being an impugnment of the Divine love and goodness, it is essential to these qualities. God, we have said, rejects and destroys nothing. But there is in things evil an element of self-destruction, in the operation of which lies the safety of the universe. Were the fact otherwise, - could individuals subsist for ever in a condition of opposition to the Divine Will,-then would evil itself be eternised ; and the universe, divided against itself, would fall. And, on the other hand, were man not free to annihilate himself, but were salvation compulsory, existence, 
instead of being a solemn reality, would be a farce wherein man and the soul would be but mechanical puppets altogether unworthy a divine creation. By the law of Heredity, God's freedom involves man's freedom; and this involves the freedom to renounce God, and with God, all Being. Thus is the saying true, "For him who will not have God, God is not."

I8. It is through the soul, and the soul only, that man learns the Divine will, and, learning it, saves himself. And the clearness with which the soul, on her part, discerns and transmits that will, depends upon her purity. In this word purity lies the essence of all religion. It is the burden of the whole Bible and of all bibles. Always is purity insisted on as the means to salvation; always impurity as the cause of condemnation. To this uniformity of doctrine the Parable of the Fall is no exception. With the soul pure, man dwells in Eden and "sees God." With the soul impure, he is driven forth into the Wilderness. Such, on the plane spiritual, is the operation of that great law of gravitation which-as has been said-is the one law of existence. Salvation and condemnation are matters of spiritual gravitation. Man tends towards or away from God - the Tree of Life-according to the specific gravity of his soul. Of this the density depends upon the nature of the affections cultivated by him. And this, again, depends upon his own Will, which is free. Wherefore, in being the regulator of his own specific gravity, he is the arbiter of his own destiny; and according as he himself wills, he tends inwards and upwards to salvation, or outwards and downwards to extinction. Yielding to the Tempter Sense, and making Matter not his means merely but his end, his soul loses at length her spiritual nature. Nevertheless, while there is life in her there is hope for him. But only through a return to 
purity. For only when she has regained her "virginity" and become "immaculate," can the Christ-his saviourbe born of her.

\section{PART II.}

19. The full significance of the Parable under consideration, and the unity of the mystic Scriptures, become conspicuously apparent when we collate their various corresponding utterances, as by taking into account those also of the Book of Revelation. For it is there that the doctrine of the Woman receives its crowning recognition as the foundation of that true Christianity which those persistent suppressors of the woman-the world's materialising priesthoods--have so nearly extinguished. Let us, then, -though at the risk of some repetition-collate these two utterances, between the delivery of which so many thousands of years elapsed.

20. In creating Man, God creates one whole and perfect being, formed of two distinct parts, Adam the earthly, exterior man, and Eve the spiritual and interior man, his soul and "living mother." These two are joined together by God in perfect union as one creature, and made, for the time, indispensable to each other. Adam, as the manifested personality or man, is not complete, that is, is not a man having Manhood, until Eve, the soul or woman, is added to him as helpmeet and guide. By the addition of her the two natures become one Humanity.

21 . From this state of perfection Humanity soon falls. For Eve, the soul, withdrawing her steadfast gaze from the proper object of her regard, namely, her spirit, God, fastens them on things below, things earthly and material, which are to her the "forbidden fruit," since her nature is spiritual. Beholding this fruit, and finding it pleasant to the eyes, she 
puts forth her hand and plucks of it, and gives of it to her husband, or Adam, to eat with her.

22. This is ever the history of sin. 'The exterior personality cannot of itself $\sin$, for it is not a responsible being. Sin is of the soul; and it comes of the soul's inclination to the things of sense. Taking of this fruit and enjoying it, she is said to eat it. And at her instigation "Adam" does likewise. And thenceforth, instead of the soul operating within him to purify and enlighten him, and lead him upwards towards the Spirit, together they become sensual and debased. And thus the sin, which has its commencement in the thought of the soul, afterwards becomes developed into action through the energy of the body or masculine part.

23. The sin consummated, the result is inevitable. Adam and his wife, the man and his soul, hear the voice of the Lord God speaking through their conscience. And sensible that they are no longer clad in the purity which alone enables man to face his Maker, they fly, as one caught naked, to hide from the Divine presence. Having rejected God, and no longer looking up to Him as her Lord and King, the soul, Eve, falls under the sway of Adam and the body. He rules her, and her desire is unto him : and thenceforth Matter has dominion in them over the spirit. The garden of perfection is lost, and the world becomes for them a wilderness.

24. Meanwhile Adam, being interrogated by the Divine Voice, lays the blame upon Eve. For, but for the soul within him, the man had not known or been capable of committing sin; sin being possible only where there is a sense of right and wrong, which the soul alone possesses. Eve, interrogated in her turn, throws the blame on the serpent of Matter-sense, or the lower nature-through 
whose allurements she has fallen. It is no particular act that thus constitutes sin. And sin does not consist in fulfilling any of the functions of nature. Sin consists in acting without or against the spirit, and in not seeking the divine sanction for everything that is done. For sin is not of the physical but of the spiritual man. And by the spirit the act is redeemed or condemned. It is sheer materialism and idolatry to regard an act as itself sinful. For to do this, is to invest that which is merely physical with a spiritual attribute.

25. The natural result of the soul's enslavement to Matter is her liability to extinction. In her own nature the soul is immortal. That is, she does not partake the death which befalls the body, but survives to take on other bodies, and continues to do so until she has finally built up a spiritual man worthy and capable of enduring for ever. But the lower she sinks herself into Matter, the lower becomes her vitality and power of recovery. So that unless she turn and mend, she must ultimately perish; for she will lose altogether the Divine Spirit which is her necessary life.

26. Notwithstanding the soul's fall, then, there is still hope of recovery for man. She shall yet, she is divinely assured, "crush the serpent's head." Not her seed only, but herself,- the soul,-when fully restored. For this is the true rendering, both in the Hebrew Scriptures and in the far older Bible of the Zodiac-that indefeasible prophecy of the soul's history. So that she who has been the cause of the fall, shall be the means also of redemption. "I will put enmity," says God to the serpent, "between thee and the woman, and between thy seed and her seed : She shall crush thy head, and thou shalt lie in wat for her heel." For the fallen soul, retaining in some degree her spirituality, and recoiling from a merely material estimate of things, 
constitutes in the man a constant protest against his engrossment by his lower nature. It is, therefore, of the soul, restored to her pure estate, and not of the body and its animal propensities, that the redeemed man must be born. The first Adam is of the earth, earthy, and liable to death. The second is "from heaven," and triumphant over death. For "sin has no more dominion over him." He, therefore, is the product of a soul purified from defilement by Matter, and released from subjection to the body. Such a soul is called virgin. And she has for spouse, not Matter-for that she has renounced-but the Divine Spirit, which is God. And the man born of this union is in the image of God, and is God made man; that is, he is Christ, and it is the Christ thus born in every man who redeems him and endows him with eternal life. For in him the man becomes transmuted from Matter into Spirit. $\mathrm{He}$ is the man himself, by regeneration become a son at once of man and of God. Generation, degeneration, regeneration,-in these three terms is comprised the whole process of the soul's history.

27. This triumphant consummation of the soul's course is thus celebrated in the Apocalypse. "I beheld," says the seer, "a great wonder in heaven: a woman clothed with the sun, having the moon under her feet, and on her head a crown of twelve stars." This is the soul invested with the light of supreme knowledge attained through the experiences undergone in the long series of her past existences; standing on the moon as victor over materiality and firm in the faith of a full intuition,-states denoted respectively by the dark and light portions of the moon; and superior evermore to the changes and chances of mortal destiny, the stars which represent this being the jewels of her crown, each of them denoting one of the "twelve 
labours" necessary to be endured by the soul on her path to her final perfectionment, and the spiritual gifts and graces acquired in the process.

28. Of the woman or soul thus exalted, the offspring is a "man-child," who is persecuted by the "serpent" of the lower world. It is a man-child for several reasons. First, because it represents the good deeds, and not intentions or thoughts merely, but actual works and positive fruits of a soul overshadowed by the Divine Spirit, and fertilised by the Divine Love. In the origination of such deeds, the outer nature or man can have no part ; they proceed wholly from the soul or woman. And they constitute a man-child, because deeds imply an exercise of the masculine element of force. And they are necessary to salvation, not because they themselves can save, but because they indicate the redemption of the individual who performs them. Faith and holy longing are feminine, and of themselves insufficient. They must be supplemented by works-which are masculine-in order to win acceptance in God's sight. "For the man is not without the woman, nor the woman without the man, in the Lord." And "the Lord" means and is the whole humanity of man and woman, as subsisting in the Divine Idea. Without the child, therefore, and this a manchild, the allegory would have been incomplete.

29. Now the good deeds thus engendered are the special aversion of the devil, or principle of evil, since, more than all else, they endanger his kingdom. Hence he is represented as seeking to annihilate both them and the soul which has given them birth. But though the soul must yet remain in the world to endure trial and persecution until the time comes for God to end her probation and call her to her final joy with Himself, it is not so with her offspring; but this is forthwith caught up to God and His throne. 
For, the good deed once wrought cannot be destroyed; but God accepts and preserves it, and the devil has no power over it. Wherefore the latter, finding it useless to pursue the man-child, redoubles his efforts against the soul, and pours forth a flood of temptations, in order, if possible, to sweep her from God's sight. She, however, though still in the "wilderness" of the flesh, is divinely sustained and delivered. The rest of her seed, the good deeds she continues to bring forth, are still the subject of persecution, until the dragon is finally overcome through what mystically is called the Blood of the Lamb, which is the pure doctrine and life whereby the elect are made sons of God and heirs of eternal life.

30. In the final exaltation which awaits her as the reward of her faithfulness, the woman, or soul, is described as arrayed by God in the white linen of righteousness, the emblem of perfect purity, and given to be the bride of His "only son," Christ Jesus. This is the man perfected through experience of suffering, and made regenerate through following his soul's pure intuition of God. And he is called the "only son," not because he is a single individual, but because only he is so designated who comes up to this description. He always is a son of God, who is the product, not of a soul defiled by contact of Matter, but of a soul pure and vitalised of the Spirit. The character or "man" thus reborn is an "only begotten son of God," because God begets none of any other kind. Of men such as this are the "saints" who "inherit the earth." And under their rule, the "New Jerusalem," or state of perfection, which "cometh down from heaven,"-the city which has God for its sun, and which has no temple, because every man is himself a house of God,-replaces the lost garden of Eden. 
31. Side by side with this epitome of the history of the pure and faithful soul, the allegory traces that of the perverse soul, under the type of an abandoned woman who sits upon the "seven hills" of the "seven deadly sins," and allies herself in wickedness with the "kings of the earth." That is, who yields wholly to the promptings of the lower nature, and accepts in all its grossness and cruelty a civilisation merely materialistic, in which the body is made all, and the spirit and every divine principle are set at nought.

32. The completeness of the parable in Genesis appears yet more distinctly when we compare the curse pronounced on Adam with man's actual condition in material respects. The sentence in its proper integrity, runs thus:- "And unto Adam God said, Because thou hast hearkened unto the voice of thy wife when beguiled of the devil, and hast eaten of the tree whereof I commanded thee, saying, Thou shalt not eat of it: cursed is the ground for thy sake; in sorrow shalt thou eat of it all the days of thy life; thorns also and thistles shall it bring forth to thee; and thou shalt eat, instead of the nobler fruit of the tree which grows spontaneously, the grosser herb of the field which requires laborious cultivation. For, in the sweat of thy face shalt thou eat bread, till thou return unto the ground out of which thou wast taken: for dust thou art, and unto dust shalt thou return." This is, God said to the bodily nature of man: "Because thou hast yielded to the solicitations of thy mate, the soul, when, turning from God, she inclined to Matter, and from being spiritual became sensual, thou must lead a hard and painful life, occupied by ignoble cares, and return by death to the lower elements to perish. Thy mate, meanwhile, though also liable to perish, shall still have long endurance, but henceforth-until finally purified and redeemed-shall bring forth her works, as the slave of 
the body, in great trouble and compunction for her fallen and degraded condition."

\section{PART III.}

33. All the mistakes made in Biblical interpretation come of referring statements of which the intention is spiritual and mystical, implying principles or states, to times, persons, or places. But though these are never the essential element in any such statement, it is, nevertheless, true that the Bible parables are either based upon certain special historical facts, or are stated in terms derived from actual occurrences; just as a hieroglyphical record is expressed in symbols drawn from the animal world, and yet has no reference to that world; so that the spiritual significations implied are not without a correspondence of some sort on the natural plane.

34. Now, the special historical fact upon the lines of which the parable of the Fall is constructed, is one whichalready implied in the account just given of the soul individual of man-is to be sought in the history of the soul collective of man,-in the history, that is, of the Church, an account of the Fall in relation to which will occupy the rest of this lecture. Sacerdotalism has always claimed for the Church the distinction of being the mystic woman through whose exaltation redemption occurs. But it has never recognised the Church as also the woman through whose fall comes the need of redemption. This reproach the priest has bestowed in a quarter in which originally there was no idea of bestowing it, and where it by no means belongs, namely, the feminine moiety of the human race. Yet, notwithstanding this assumption of sacerdotalism, it is to the fall of the Church from the standard attained in the Edenic period, that, in one of its aspects, the parable refers. 
35. Even so, however, the interpretation is not to be restricted to any single or special instance. It is only as a type of all Churches that the first or best Church is employed, precisely as the soul of the first or best man may be employed as a type of all souls. And any less general application would deprive the parable of its due place as an eternal and universal verity, and reduce it to the level of the merely historical and local.

36. Nor, in likening all Churches one to another in respect of their fall, is it intended to assimilate them in respect of the height from which they have fallen. All that is meant is, that, whatever the level of spiritual perfection attained by any mystic community or Church in the full flush of its enthusiasm and purity, there is always a fall from such level, and the fall is due to one and the selfsame cause, namely, that which is implied in the parable of Eden, and of which account has just been given in relation to the soul as individual. For of the soul's fall, whether in one or in many, the cause is always the same,the inclination to Matter.

37. The rise also is the same, both in cause and in method. And it is of this-the rise, that is, of the earliest known-perhaps the original-Church of Christ-that we have first to speak. This, as with man himself, was by evolution from rudimentary being. For the doctrine of creation by evolution is, as already stated, a true doctrine; and it is true as regards both man's physical and man's spiritual history. And it has been the doctrine of Mysticism from the beginning, the knowledge of it being reserved for initiates of a high grade. But between it and the travesty of it propounded by the science-wholly materialistic - of our day, is this essential difference. That science, - "falsely so called,"-in its ignorance of the nature of 
Substance, credits Matter with a power of evolution while denying to it the properties through which alone evolution can occur, namely, inhering life and consciousness. This science, moreover, contemplates as possible the development of that which, being infinite and eternal, is necessarily all-perfect in perpetuity, namely, the substance of existence. For mysticism, on the contrary, existenceor, more properly, Being-and consciousness are terms synonymous and interchangeable; and all Substance, under whatever mode manifested, continues still to be, in some mode, consciousness. And inasmuch as Substance itself is incapable of development, in the sense of becoming more or better than it originally is, development is not of the qualities of substance, but of the manifestation of those qualities in individuated portions of it, a process whichconsisting in the unfoldment of qualities already subsisting, but latent-may fairly be designated evolution.

38. The man spiritual, like the man physical, - the Church, like the world,-then, represents a development from rudimentary being, occurring in virtue of the nature of the substance of which that being represents the projection; and the only difference between them is of degree or stage of development. And whereas the lowest or material plane is that wherein the process commences, the highest and last to be attained is the celestial. According to the degree in which he attains this, man attains the divine and is at one with God, having, in virtue of the knowledge thus derived, power "over things in heaven and things on earth,"-power, that is, over both regions, the spiritual and the material, of his own nature, and being altogether superior to the seductions of the illusory astral which lies between.

39. This celestial sphere was attained by the Edenic 
Church in a degree never reached by any other. Wherefore, since that alone is such a Church in which it is attained, no Church which has subsequently existed has been truly Edenic; but all have been Churches of the Fall. In Eden alone was man made in the "image of God," being called in token thereof, Adam and Eve. Then was the first man, according to the mystical definition of the term. Men and women, indeed, had subsisted on the earth for ages before him ; but not man properly so called. They were-as the vast majority of men and women still areman only in the making, or, it may be, in the marring. Man attains manhood and becomes Man, only when he reaches his spiritual majority. The attainment of the celestial did not, and does not, involve the abandonment of the terrestrial. The not uncommon notion, that man in his primal perfection was a non-material or fluidic being, having no material body, is erroneous. Man, while yet in the body, attained "power over the body"; from fixed, making it volatile, and, though not immortal, capable of an indefinitely prolonged existence, its vitality meanwhile being such as not only to render it superior to disease and injury in itself, but as to enable it to communicate health to others. These results, however,-stupendous as they would now be deemed,- - did not exhaust the potentialities of our race. There is a superior stage of which account will be given when we come to treat particularly of the redemption, and which belongs to a period of development transcending that of the Adamic man. Nevertheless, though not realising all the possibilities of humanity, the Edenic Church attained, in its representative members, as no other religious community has attained. And it was through that Church's failure to continue at the same high level, that the fall whereof we are treating occurred. By 
this fall, man receded from the celestial back towards his original level, the terrestrial, becoming once more subject to Matter, and losing the power over his body. There was no fall on the part of the individuals themselves who had risen. These quitted the earth and passed on to higher conditions of being. The Fall came through the failure of the succeeding generations to attain the level reached by their predecessors. Failing to attain, like them, the celestial, man remained - where, with a few individual exceptions, he has ever since been - in the astral and material.

40. Let us attempt a description of that inmost spherethe abode of the man celestial-which is at once the source of doctrine and the sphere wherein-as representative of the soul and intuition - the woman especially presides. It is a memory that we are about to recall, 4 a memory recovered of an age not absolutely but relatively "golden," to revisit which in thought, is to revert to a period in the world's youth, when, as yet unpoisoned by all-pervading sin and disease, the conditions of life were so exquisite in their purity and harmony, as to make existence itself a positive, intense delight. And while in the act of recovering that memory, and enjoying again that remote past, the mind is able to look forward as well as backward, and to behold the whole subsequent period of the world's coursethat which is called the historical period-as but a season -brief compared with that which preceded it-of sickness

4 The account of the Order or Community referred to in paragraphs 40-49 was elaborated by Edward Maitland out of his own inmost consciousness, his feeling all the while being that he was recalling a recollection of his own appertaining to some long-past existence in which he had himself been a member of such an Order (Life of $A$. $K$., vol. ii., p. 66). 
and suffering which the race, by its own fault, has brought upon itself; but from which, it seems, rescue is not impossible, can humanity but furnish the love needful for the task of saving itself. For in those hyper-lucid moments it is made to appear as a self-evident truth, that just as it has been possible for us in the past to live healthily and happily, it will be possible for us to do so in the future. For Utopia is Utopia only for those who insist that it shall for ever be Utopia and unrealised. There is no force in the universe save will-force; and all that life needs for life is possible to will. And, continuing to operate over an indefinite period, even a finite will becomes infinite. Wherefore man has but to will long enough, to make the world as he would have it. But to will is not merely to wish, but to work towards the desired end. It is for the woman in us to wish, and therein to prompt. She is the inspirer. But the man in us must work. $\mathrm{He}$ is the executor. Apart, powerless; together, they can move the world. $\mathrm{He}$ and She, Will and Love, Spirit and Substance, operating in the celestial, created the world; and assuredly they can redeem it.

41. That which we propose to describe,-so far as the attempt to reconstruct it has been successful,--is the innermost sphere, not, indeed, of the mystic community of Eden itself, but of one of those ancient successors of and approximations to it, which, as Colleges of the Sacred Mysteries, were the true heirs of Eden, and which, so recently even as by Plato, were described as places wherein were repaired the effects of the Fall, and to quit which for the outer world was to quit once more the garden for the wilderness. Once accessible to all, so completely now has the true character of these institutions fallen from remembrance, that even scholars write them down as instruments of imposture and 
oppression, and devoid of special knowledge or faculty. Wherefore to recover them is to re-create them;-no small task, seeing that the way to them, even in thought, is barred and banned by all the priesthoods, so that only by facing and piercing the formidable phalanx of sacerdotalism itself, can the forbidden ground of those lost paradises be even approached.

42. For - as recorded in classic legend - the golden fruit of a perfect doctrine and life, produced on the union of Zeus and Hera, - the man and woman of the substantial humanity, -is guarded not only by the dragon of man's own lower nature, but also by the "daughters of the sunset," - the world's materialistic sacerdotalisms. And these, together with dragon and sword of flame, keep watch and ward, lest any, re-entering the closed garden, may find, and pluck, and eat, and know, and, knowing, have life in himself, needing no assistance of priest. And so fierce and vigilant is the watch kept, that only a Heracles-or man already half divine-can succeed in piercing or evading the formidable phalanx.

43. Let us suppose this done, and the priestly lines safely passed and left behind. Traversing the broad belt which divides these lines from the wished-for centre, the seeker descries at length a Mount, towards the summit of which the sky appears to dip, so that by the meeting of the two a junction is formed between the earth and heaven. Thus does it appear to the interior vision, with which, to be a successful follower of such quest, the seeker must be endowed. That which he finds on reaching the Mount, is a community of beings, of both sexes, to the ordinary eyes human, but to the interior divine also. And the life they lead-though outwardly quiet, grave, uneventful, and, as some would deem it, even ascetic-in reality throbs with 
intensest vitality, abounds in enterprise the most lofty, and brims with keenest satisfaction. For, of this community the members are, of all mankind, the profoundest of intelligence, widest of culture, ripest of experience, tenderest of heart, purest of soul, maturest of spirit. They are persons who-using life without abusing it, and having no perverse will to the outer-have learnt all that the body has to teach, and who, rising above earth by the steadfast subordination of their lower, and exaltation of their higher nature, have at length - to use their own most ancient and significant phrase - crucified in themselves the flesh, and thereby made of their bodies instruments, instead of masters, for their souls, and means of expression, instead of sources of limitation, for their spirits. Thus rising above the earth, they have drawn down heaven to meet them; and, like the revolving rain-cloud of tropic seas, formed a pillar of communication between the spheres upper and nether.

44. An Order, or School, do these compose, whereof the initiates, while honouring the man as the heir of all things, -if only he be lawfully begotten and be a true child of the Spirit,-especially champion the woman, by exalting her within themselves to share supremacy with the man, making themselves at once man and woman. For together with the intellect, they cherish also the intuition, together with the liead, the heart, and combining in all things love with will, make it their one object to enable the substance of their humanity to attain in them the full manifestation of its qualities. Practisers as well as preachers of the doctrine of creation by development, and-withheld by no prepossession or prejudice-fearless followers of thought to its extremest spheres in every direction, they are the earth's sole genuine evolutionists and free-thinkers; and to them alone, and those who, affiliated to them, know and follow 
their method, it is given, while in the body, to live the life of the spirit; to reach their intellectual manhood; to complete the system of their thought, and find certitude of truth even the highest; to attain the supreme common sense of all the spheres and modes of being in which substance is wont to be manifested; and, in a word, to be taught of the informing Spirit Itself of the universal humanity, all the mysteries of that kingdom which, being within, is the counterpart of and sole key to that which is without.

45. Of all who attain eminence in this School-and these have been, and haply shall yet again be, many-the motive is one and the history one. For the motive is the love of perfection, for the sake, not of self only, but of perfection. And this is a goal which, pursued as these pursue it, continues ever to rise, and draws the pursuer after it. And the history is that of the soul. For, as the soul is one, so also is her history one.

46. From this order, wherever established, have proceeded, as from a central sun, all the light and heat of knowledge and goodness which, distributed through faithful priesthoods, have ministered towards the world's redemption from utter ignorance and barbarism to such degree of humanity as it has reached. From the germs of truth and beauty, in doctrine and conduct, idea and practice, thus originated, and transferred to various soils, has sprung all that the world has of true philosophy, morality, art, science, civilisation, religion. And in so far as the products have been lacking in excellence, the fault has been due, not to the original seed, but to the soil and to the husbandmen.

47. How stubborn that soil, and how inefficient or faithless those husbandmen, may be inferred from the fact that 
rarely, since history began, has the Order found in the smallest degree the recognition and gratitude its due. But, on the contrary, whenever, in a period of degradation so extreme that humanity itself seemed in its death-throe, and instead of men the earth bore monsters, - one of its members has quitted his loved seclusion and, descending from his own celestial "Mount" into the world below, has sought by conduct and precept to afford an example of what humanity has in it to be,-he has by the world he sought to rescue been subjected to persecution and affront, and in the official guardians of the doctrine he represented and would have regenerated, has found his bitterest foes.

48. Long vanished from human view, the Order has been replaced by semblances, mechanical merely and void of vitality; and for lack both of the knowledge and of the materials, incompetent to build up a single specimen of humanity after its perfected pattern. Nevertheless the true Order still survives, though dwindled in numbers and no longer having organisation or appliance due ; but as "a people scattered and peeled," lost tribes of a spiritual Israel, whose roll call is no more on earth. Once known and supremely honoured by the titles of Magi, Wise Men, Kings of the East, and Sons of God, its initiates are now misknown and supremely contemned under the designation of Mystics. Yet, notwithstanding the uncongenial climate and evil entreaty of a civilisation become wholly materialistic, these still pursue - unknown for the most part even to each other-their ancient vocation; and still is this, as of old, the Gnosis, or Divine Science. For its subject is the Substance of the universal Humanity, and its object is the attainment of personal perfection.

49. Of all earthly Orders, this, by reason of its antiquity, its universality, its objects, and its achievements, is incom- 
parably the most notable, seeing that from it have proceeded all the world's true sages, saints, seers, prophets, redeemers, and Christs; and through it all divine revelation. And its doctrine is that one true doctrine of existence, and therein of religion, which-always in the world-is now for the first time in its history published to the world in language comprehensible by the world;having, it is confidently believed, been recovered in the way in which it was originally received.

\section{PART IV.}

50. It remains to speak of the cause and manner of the fall from a level so lofty, from a rule so beneficent. The truth is, that the world fell only because the Church fell. And the Church, or collective soul of Humanity, fell, as does the individual soul, by looking less and less upward to God, and more and more downward to Matter. Cataclysmal as the result may appear when viewed in the totality of its effects and from a distance of time, the declension was very gradual, and extended over many generations. It may thus be compared to a diminution of agricultural produce, such as occurs through the gradual impoverishment of the soil. The spiritual possibilities of the race had, as it were, exhausted themselves. Or it may be likened to a recession of the tides of the sea, and to the seasons of the year. For, until finally united to God by what, mystically, is called the Divine Marriage, man is subject to many fluctuations and alterations in respect of his spiritual condition. And instead of the wave of his spiritual life remaining always at high water, it falls back to rise in another tide,- - a tide, it may be, as in this case, to culminate only after another creative "week" of man's spiritual forma- 
tion, of which every "day" should be a "thousand years." In the sense and manner ordinarily supposed, mankind never fell. Its fall was gradual as its rise. Under the ripening influence of a vast wave of spiritual light and heat, - to the production of which man himself had contributed his necessary quota, by voluntary co-operation with the Divine Spirit working within him,- he attained the first great summer of his perfection, in the time and manner indicated in the parable of Eden and the legends of the Golden Age. Upon the subsidence of this wave-a subsidence due to himself-he fell from his summer back into the spiritual autumn and winter in which he has remained buried more or less deeply ever since. And now he is at the lowest depth compatible with any retention at all of existence. Another step in the same direction means for Humanity--in the mystical and true sense, and that is in every high sense-total extinction.

51. As with the Individual, so with the Race. The path of ascent from rudimentary being is also the path of descent when, through a perverse will to the outer, descent occurs. Man rose into man, and attained the full image of God, through the culture of the woman within him. Representing his soul and intuition of God, she was his initiator into the knowledge of divine things. And led by the clear perceptions which are her special gift when duly tended and honoured, he learnt to shun idolatry-which is the preference for the Form over the Substance-and bloodshed (whether for soul or body), and with these whatever might serve to obscure or distort his conceptions of the Divine Character. Thus exalting the woman on the spiritual and intellectual planes of her manifestation in humanity, he exalted her also on the planes social and political; and instead of seeing in her-as do the fallen philosophies and 
sacerdotalisms of all subsequent ages-a thing maimed and defective, and-however fair-a mistake and a blunder of Nature, to be classed with criminals, idiots, and children, and yet to be held responsible for all the evils of existence, - he regarded her as a later and higher development upon himself, and as, of the two, the nearer to God. And richly did she repay him for the preference, so long as it was accorded to her. For through her he attained Paradise. But as, when pure and uncorrupted, the soul is man's initiator into things divine; so when, turning towards the things of sense, the soul loses her purity, she becomes his initiator into things evil, and gives him of the fruit of forbidden knowledge, making him a "sinner," which, but for the soul, he could not be. For "by the law is the knowledge of sin," and the law is given to the soul. The Fall, therefore, when at length it came, came not through any individual person, woman or man, but through the fault of man, and was due to the fall of the woman in himself. Following her intuition of God, he had ascended from the material, through the astral to the celestial, and became made in the "image of God." Following her in her fall into Matter, he descended by the same way to where he now is, his path being one continuous track of agony, tears, and blood, due solely to the suppression within himself of the "woman."

52. At once the cause and consequence of the Fall, the manifestation of this suppression is always threefold. The loss of the intuition means idolatry, and idolatry means murder. Each of these is a condition of the other. Losing his intuition of Spirit, man becomes Materialist, and instead of the spiritual idea, which alone is real, worships the visible symbol. That is, he ignores the soul and exalts the body of things. Exalting the body, he sacrifices all to the body, 
and sheds, for its gratification, innocent blood. Thus is he murderer as well as idolater. The woman in him falling, he becomes "Cain," a cultivator of "the fruits of the ground" only, or lower nature, whence proceeds all evil. In other words, for a doctrine of love he substitutes a doctrine of selfishness. For this is the sin of which bloodshed is the symbol and outcome.

53. Since these are the three steps of his descent, to reverse his practice in respect of them-in the Spirit as well as in the Letter-will be to reverse the Fall, and to remount once more to the celestial. Already has the movement begun in each regard. The position of woman on the lower planes is being rapidly revolutionised, and soon will be so also on the higher. Little, however, do most of those who are working to that end know what it means, and little will the end coincide with their anticipations. For many who in our day are pretending to "exalt the woman" are doing so by means subversive of her. And many even of the women who are seeking to exalt themselves, are doing so by the repression, rather than by the promotion, of their womanhood; and this, by reason, not of their doing man's work, but of their doing it in man's evil fashion, leaving out the woman. Nevertheless, the woman shall be exalted. God will carry her to His throne, and "will make the wrath of man to praise Him." The outcry, surely gathering volume and strength, against the slaughter and torture of our animal brethren, whether for use or for pleasure, is another token of entrance upon the upward path. It is not at the hands of those who kill or eat them, that the animals will be permitted to accept their salvation from the torturer. They who would redeem others must first make sacrifice in themselves. When this truth is understood, the redemption of the animals will be at hand. And in respect of 
idolatry the prospect is even yet brighter. For the "Gospel of Interpretation " has come, and the "letter which killeth" is henceforth shorn of its strength.

54. Do we speak of signs? What sign more astounding could have been imagined than the modern phenomenon known as "Spiritualism"? Herein man has already taken one whole step upward towards the celestial. For in "Spiritualism" he has quitted the exclusively material, and has actually entered the astral. Short of the celestial now he cannot stop. The very profundity of his dissatisfaction with his experiences of the astral, will compel him onwards. To this every "Spiritualist" will testify. Backward man dare not turn, to the merely material. For he has beheld in vivisection the abyss which confronts him there, and in healthy horror has recoiled from the bottomless pit therein disclosed, of the possibilities of his own lower nature. In vivisection the human is abandoned for the infernal.

55. The cry, then, is onward, upward, inward to the celestial. And happy will they be who first are uplifted thither, for they will surely draw all men up after them. Reversing the Fall and the Curse of Eve, they will lead Man to a new Golden Age, a new sabbath of Perfection, and the glories of the New Jerusalem, that true City of Hygieia, which cometh down from the heaven of his own pure Ideal. Thus will the divine Virgin Astræa-forced to quit earth when the Golden Age was no more-fulfil the promise of her return, bringing her progeny of divine sons, to redeem the world. ${ }^{5}$ Thus, too, will Intuition and Intellect, as a new Esther and Mordecai, once more gain favour with the

${ }^{5}$ Jam redit et Virgo, redeunt Saturnia regna, Jam nova progenies ccelo dimittitur alto.

Virgil, Eclog. IV. 
world, and, redeeming from oppression the true Israel, give the kingdom to the righteous. Moreover in these faculties, thus restored, will the "two "Apocalyptic "Witnesses" rise, as from the dead, in "the streets of the great City," and "ascending into heaven," reign supreme. And thus also will the dream of King Nebuchadnezzar find its fulfilment, and the Golden Image its destruction. For the Image is the symbol of a civilisation whose head-or intellect-is golden, but whose body is of silver mixed with brass, and whose legs and feet are iron and clay; - that is, which rests on Force and Matter. And the Stone, hewn without hands, which destroys it, is the Understanding, manifested in a new Word or Gospel of Interpretation, which, smiting the monster mis-called Civilisation, shall "scatter in pieces the iron, the clay, the brass, the silver, and the gold, and make them as the chaff of the summer threshingfloor." But the "Stone " by which the Image is destroyed shall "become a great mountain, and fill the whole earth." Becoming the " head corner stone," by it the Great Pyramid of the standard Humanity shall be completed. 


\section{LECTURE THE EIGHTH.1}

\section{THE REDEMPTION.}

\section{PART I.}

I. That, then, which, mystically, is called the Fall of Man, does not mean, as commonly supposed, the lapse, through a specific act, of particular individuals from a state of original perfection; nor, as sometimes supposed, a change from a fluidic to a material condition. It means such an inversion of the due relations between the soul and the body of a personality already both spiritual and material, as involves a transference of the central will of the system concerned, from the soul-which is its proper seat-to the body, and the consequent subjection of the soul to the body, and liability of the individual to sin, disease, and all other evils which result from the limitations of Matter.

2. That, therefore, which, mystically, is called the Redemption, and which is the converse of the Fall, does not mean, as commonly supposed, the remission, or transference from the guilty to the innocent, of the penalties incurred through the Fall. No penalty incurred by man ever is or

1 This lecture was written by Edward Maitland chiefly from Illuminations of Anna Kingsford: and was delivered by him on Monday the IIth July, I88I. The greater part of paragraphs 27-4I was written after the death of Anna Kingsford for the Third Edition, in which they were substituted for the corresponding paragraphs in the two former Editions. These last mentioned paragraphs are reprinted in App. II. ( $L$ ife of $A . K$., vol. ii., pp. 16, 17, 32, 33, and see Pref.). 
can be remitted by God, since the Divine Justice is just. Nor, for the same reason, can it be borne by another, since a substitution of the innocent for the guilty would in itself be a violation of justice. Wherefore the doctrine of Vicarious Redemption, as ordinarily accepted, represents a total misconception of the truth, and one derogatory to the Divine Character. The Redemption means such removal of the will of the individual system concerned, from the body, and reinstatement of it in the soul, as thenceforth to secure to the soul full control over the body, and to exempt the individual from further liability to transgression. He who is redeemed cannot sin, that is, mortally.

3. It is according to the Divine order of Nature that the soul should control the body. For, as a manifested entity, man is a dual being, consisting of soul and body; and of these, in point both of duration and function, and therefore in all respects of value, the precedence belongs to the soul. For the soul is the real, permanent Individual, the Self, the everlasting, substantial Idea, of which the body is but the temporary residence and phenomenal expression. The soul, nevertheless, has, properly speaking, no will of her own, since she is feminine and negative. And she is therefore, by her nature, bound to obey the will of some other than herself. This other can be only the Spirit or the Body; - the Within and the Above, which is Divine, and is God; or the Without and the Below, which, taken by itself and reduced to its last expression, is the "devil." It is, therefore, to the Spirit and soul as one, that obedience is due. Hence, in making the body the seat of the will, the man revolts, not merely against the soul, but against God; and the soul, by participation, does the same. Of such revolt the consequence is discase and misery of 
both soul and body, with the liability, ultimately, to extinction of the soul as well as of the body. For the soul which persistently rejects the Divine Will in favour of the bodily will, sins mortally, and, becoming mortal, at length dies. For her life is withdrawn and her constituents are scattered to the elements ; so that, without any actual loss either of the Life or of the Substance of the universal existence, the individuality constituted of them perishes. The "man" is no more. "He that gathereth not with $\mathrm{Me}$, scattereth."

4. The result, on the other hand, of the soul's steadfast aspiration towards God,-the Spirit, that is, within her,and of her consequent action upon the body, is that this also becomes so permeated and suffused by the Spirit, as, at last, to have no will of its own, but to be in all things one with its soul and Spirit, and to constitute with these one perfectly harmonious system, of which every element is under full control of the central Will. It is this unification, occurring within the individual, which constitutes the Atonement. And in him in whom it occurs in its fullest extent, Nature realises the ideal to attain which she first came forth from God. For in the man thus redeemed, purified, and perfected in the image of God, and having in himself the power of life eternal, she herself is vindicated and glorified, and the Divine Wisdom is justified of her children. The process, however, is one which each individual must accomplish in and for himself. For, being an interior process, consisting in self-purification, it cannot be performed from without. That whereby perfection is attained is experience, which implies suffering. For this reason the man who is reborn in us of "Water and the Spirit,"-our own regenerate Self, the Christ Jesus and Son of Man, who in saving us is called the Captain of our salvation,-is said to be made perfect through suffering. This suffering must be borne by each 
man for himself. To deprive any one of it by putting the consequences of his acts upon another, so far from aiding that one, would be to deprive him of his means of redemption.

5. There are two senses in which the term Fall is used, each of them having relation to an indispensable epoch in the process of the universe. The one is the fall of Spirit, the other of the soul. The first occurs in the universal, and concerns the Macrocosm. The second occurs in the individual, and concerns the Microcosm. The first and general descent of Spirit into Matter consists in that original projection of the Divine Substance from pure Being into the condition of Existence, whereby Spirit becomes Matter, and Creation occurs. The doctrine which regards the universe as the Thought of God, is a true doctrine. But the universe is not therefore unsubstantial. God is real Being, and that which God thinks is also God. Wherefore, in consisting of the thought of the Divine Mind, the Universe consists of the Substance of that Mind, the Substance, that is, of God. God's Ideas, like God, are real beings, Divine Personages, that is, Gods. Put forth by, and, in a sense divided from, God, in order to accomplish God's purposes, these become messengers of God, that is, Angels. And, of them, those to whom is assigned a condition below that of God $-a$ condition no longer of Spirit-are called "Fallen Angels." Wherefore the "Fall of the Angels" denotcs simply the original and kosmic descent of Spirit into the condition of Matter, - the precipitation, that is, of the Divine Substance from a state of pure Being, into the various elements and modes which are comprised in and which constitute Existence or Creation. Creation is thus, not, as ordinarily supposed, a making out of that which is not, but a manifestation or putting forth-by the conversion of 
essence into things-of that which already is, but which subsists unmanifest. It is true, that prior to such manifestation, there is no thing. But this is not because there is nothing; but because before things can exist, the ideas of them must subsist. For a thing is the result of an idea, and except as such cannot exist. Thus, Matter, as the intensification, or densification, of Idea, is a mode of the Divine consciousness, put forth through an exercise of the Divine Will ; and being so, it is capable, through an exercise of the Divine Love, of reverting to its original, unmanifest condition of Spirit. The recall of the universe to this condition constitutes the final Redemption or "Restitution of all things." And it is brought about by the operation of the Divine Spirit within the whole.

6. The Redemption from the other of the two Falls specified, is due to the operation of the divine element within the individual. And it is of this alone that we propose to treat on this occasion. As already stated, this Fall does not consist in the original investment of the soul with a material body. Such investment-or incarnation-is an integral and indispensable element in the process of the individuation of soul-substance, and of its education into humanity. And until perfected, or nearly so, the body is necessary to the soul in turn as nursery, school, house of correction, and chamber of ordeal. It is true that redemption involves deliverance from the need of the body. But redemption itself is from the power of the body; and it is from its fall under the power of the body that the soul requires redemption. For it is this fall which, by involving the alienation of the individual from God, renders necessary a reconciliation or at-one-ment. And inasmuch as this can be effected only through the total renunciation of the exterior or bodily will, and the unreserved acceptance in its 
place of the interior or Divine Will, this at-one-ment constitutes the essential element of that Redemption which forms the subject of the present discourse.

7. Although Redemption, as a whole, is one, the process is manifold, and consists in a series of acts, spiritual and mental. Of this series, the part wherein the individual finally surrenders his own exterior will, with all its exclusively material desires and affections, is designated the Passion. And the particular act whereby this surrender is consummated and demonstrated, is called the Crucifixion. This crucifixion means a complete, unreserving surrender,to the death, if need be,-without opposition, even in desire, on the part of the natural man. Without these steps is no atonement. The man cannot become one with the Spirit within him, until by his "Passion" and "Crucifixion," he has utterly vanquished the "old Adam" of his former self. Through the atonement made by means of this selfsacrifice he becomes as one without sin, being no more liable to sin; and is qualified to enter, as his own highpriest, into the holy of holies of his own innermost. For thus he has become of those who, being pure in heart, alone can face God.

8. The "Passion" and "Crucifixion" have their immediate sequel in the Death and Burial of the Self thus renounced. And these are followed by the Resurrection and Ascension of the true immortal Man and new spiritual Adam, who by his Resurrection proves himself to belike the Christ- "virgin-born," in that he is the offspring, not of the soul and her traffic with Matter and Sense, but of the soul become "immaculate," and of her spouse, the Spirit. The Ascension, with which the Drama terminates, is that of the whole Man, now regenerate, to his own celestial kingdom within himself, where-made one with 
the Spirit-he takes his seat for ever "at the right hand of the Father."

9. Although the Resurrection of the man regenerate has a twofold relation, in that it sometimes affects the body, the resurrection is not of the body in any sense ordinarily supposed, nor is the body in any way the object of the process. The man, it is true, has risen from the dead. But it is from the condition of deadness in regard to things spiritual, and from among those who, being in that condition, are said to be "dead in trespasses and sins." In these two respects, namely, as regards his own past self and the world generally, he has "risen from the dead"; and "death," of this kind, "has no more dominion over him." And even if he have redeemed also his body and made of it a risen body, this by no means implies the resuscitation of an actual corpse. In this sense there has been for him no death, and in this sense there is for him no resurrection. It was through misapprehension of the true doctrine, and the consequent expectation of the resurrection of the dead body, that the practice-originally symbolical and special -of embalming the corpse as a mummy, became common, and that interment was substituted for the classic and far more wholesome practice of cremation. In both cases, the object was the delusive one of facilitating a resuscitation at once impossible and undesirable, seeing that if reincarnation be needful, a soul can always obtain for itself a new body.

10. That which constitutes the Great Work is not the resuscitation of the dead body, but the redemption of Spirit from Matter. Until man commits what, mystically, is called idolatry, he has no need of such redemption. So long as he prefers the inner to the outer, and consequently polarises towards God, the will of his soul is as the Divine Will, and she has, in virtue thereof, power over his body, 
as God has over the universe. Committing idolatry, by reason of perverse will to the outer,-looking back, and down, that is, and preferring the form to the substance, the appearance to the reality, the phenomenon to the idea, the "city of the Plain" to the "mount of the Lord,"-she loses this power, and becomes a "pillar of salt," material and patent to sense, and, hence, "naked." The " resurrection body" is altogether sublime, being woven for herself by the ascended soul out of elements transcending aught the physical corpse can yield; for it is her own "unfallen" substance. It is not a body raised, but a raised body.

\section{PART II.}

I I. In order to obtain an adequate conception of the vastness of the interval between the conditions of man "fallen " and man "redeemed," it will be necessary to speak yet more particularly of the man perfected and having power. Thus contrasted, the heights and depths of humanity will appear in their true extent. It is but a sketch, comparatively slight, which can here be given of what they must endure, who, for love of God, desire God, and who, by love of God, finally attain to and become God; and who, becoming God without ceasing to be man, become God-Man,-God manifest in the flesh,-at once God and Man. The course to this end is one and the same for all, whenever, wherever, and by whomsoever followed. For perfection is one, and all seekers after it must follow the same road. The reward, and the means towards it, are also one. For "the Gift of God is eternal Life." And it is by means of God,-the Divine Spirit working within him, to build him up in the Divine Image,-he, meanwhile cooperating with the Spirit,--that man achieves Divinity. In 
the familiar, but rarely understood terms, "Philosopher's Stone," "Elixir of Life," "universal Medicine," "holy Grail," and the like, is implied this supreme object of all quest. For these are but terms to denote pure Spirit, and its essential correlative, a Will absolutely firm and inaccessible alike to weakness from within and assault from without. Without a measure of this Spirit is no understanding-and therefore no interpretation-of the Sacred Mysteries of Existence. Spiritual themselves, they can be comprehended only by those who have, nay, rather, who are Spirit; for God is Spirit, and they who worship God must worship in the Spirit.

I 2. The attainment in himself of a pure and divine Spirit, is, therefore, the first object and last achievement of him who seeks to realise the loftiest ideal of which humanity is capable. He who does this is not an "Adept" merely. The "Adept" covets power in order to save himself only; and knowledge is for him a thing apart from love. Love saves others as well as oneself. And it is love that distinguishes the Christ; - a truth implied, among other ways, in the name and character assigned in mystic legends to the favourite disciple of the Christs. To Krishna, his Arjun; to Buddha, his Ananda ; to Jesus, his John;-all terms identical in meaning, and denoting the feminine and tender moiety of the Divine Nature. He therefore, and he alone, who possesses this spirit in quality and quantity without measure, has, and is, "Christ." He is God's Anointed, suffused and brimming with the Spirit, and having in virtue thereof the power of the "Dissolvent" and of "Transmutation," in respect of the whole man. Herein lay the grand secret of that philosophy which made "Hermes" to be accounted the "trainer of the Christs." Known as the Kabbalistic philosophy, it was a philosophy-or rather a 
science-based upon the recognition in Nature of a universal Substance, which man can find and "effect," and in virtue of which he contains within himself the seed of his own regeneration, a seed of which-duly cultured-the fruit is God, because the seed itself also is God. Wherefore, the "Hermetic science" is the science of God.

13. "Christ," then, is, primarily, not a person, but a principle, a process, a system of life and thought, by the observance of which man becomes purified from Matter, and transmuted into Spirit. And he is a Christ who, in virtue of his observance of this process to its utmost extent while yet in the body, constitutes a full manifestation of the qualities of Spirit. Thus manifested, he is said to "destroy the works of the devil," for he destroys that which gives pre-eminence to Matter, and so re-establishes the kingdom of Spirit, that is, of God.

14. This, the interior part of the process of the Christ, is the essential part. Whether first or last, the spiritual being must be perfected. Without this interior perfection, nothing that is done in the body, or exterior man, is of any avail, save only in so far as it may minister to the essential end. The body is but an instrument, existing for the use and sake of the soul, and not for itself. And it is for the soul, and not for itself, that it must be perfected. Being lut an instrument, the body cannot be an end. That which makes the body an end, ends with the body; and the end of the body is corruption. Whatever is given to the body is taken from the Spirit. From this it will be seen what is the true value of Asceticism. Divested of its rational and spiritual motive, self-denial is worthless. Rather is it worse than worthless; it is materialistic and idolatrous; and, being in this aspect a churlish refusal of God's good gifts, it impugns the bounteousness of the Divine nature. The aim of all 
endeavour should be to bring the body into subjection to, and harmony with, the spirit, by refining and subliming it, and so heightening its powers as to make it sensitive and responsive to all the motions of the Spirit. This it can be only when, deriving its sustenance from substances the purest and most highly solarised, such as the vegetable kingdom alone affords, it suffers all its molecules to become polarised in one and the same direction, and this the direction of the central Will of the system, the "Lord God of Hosts" of the Microcosmic Man,-Whose mystic name is Adonai.

15. The reason of this becomes obvious when it is understood that the Christs are, above all things, Media. But this not as ordinarily supposed, even by many who are devoted students of spiritual science. For, so far from suffering his own vivifying spirit to step aside in order that another may enter, the Christ is one who so develops, purifies, and in every way perfects his spirit, as to assimilate and make it one with the universal Spirit, the God of the Macrocosm, so that the God without and the God within may freely combine and mingle, making the universal the individual, the individual the universal. Thus inspired and filled with God, the soul kindles into flame; and God, identified with the man, speaks through him, making the man utter himself in the name of God.

16. It is in his office and character as Christ, and not in his own human individuality, that the Man Regenerate proclaims himself "the way, the truth, and the life," "the door," and the like. For, in being, as has been said, the connecting link between the creature and God, the Christ truly represents the door or gate through which all ascending souls must pass to union with the Divine; and save through which "no man cometh unto the Father." It is 
not, therefore, in virtue of an extraneous, obsessing spirit that the Christ can be termed a "Medium," but in virtue of the spirit itself of the man, become Divine by means of that inward purification by the life or "blood" of God, which is the secret of the Christs, and "doubled" by union with the parent Spirit of all,-the "Father" of all spirits. This Spirit it is Whom the typical Regenerate Man of the Gospels is represented as calling the "Father." It is the Unmanifest God, of Whom the Christ is the full manifestation.

17. Hence he disavows for himself the authorship of his utterances, and says, "The words which I speak unto you I speak not of myself. The Father which dwelleth in me, He doeth the works." The Christ is, thus, a clear glass through which the divine glory shines. As it is written of Jesus, "And we beheld his glory, the glory as of the Only Begotten of the Father, full of grace and truth." Now, this "Only Begotten" is not mortal man at all, but $\mathrm{He}$ Who from all eternity has been in the bosom of the Father, namely, the Word or Logos, the Speaker, the Maker, the Manifestor, He Whose mystic name, as already said, is Adonai, and of whom Christ is the counterpart.

18. To attain to the perfection of the Christ, - to polarise, that is, the Divine Spirit without measure, and to become a "Man of Power" and a Medium for the Highest,though open potentially to all,-is, actually and in the present, open, if to any, but to few. And these are, necessarily, they only who, having passed through many transmigrations and advanced far on their way towards maturity, have sedulously turned their lives to the best account by means of the steadfast development of all the higher faculties and qualities of man; and who, while not declining the experiences of the body, have made the spirit, and 
not the body, their object and aim. Aspiring to the redemption in himself of each plane of man's fourfold nature, the candidate for Christhood submits himself to discipline and training the most severe, at once physical, intellectual, moral, and spiritual, and rejects as valueless or pernicious whatever would fail to minister to his one end, deeming no task too onerous, no sacrifice too painful, so that he be spiritually advanced thereby. And how varied soever the means, there is one rule to which he remains constant throughout, the rule, namely, of love. The Christ he seeks is the pathway to God; and to fail, in the least degree in respect of love, would be to put himself back in his journey. The sacrifices, therefore, in the incense of which his soul ascends, are those of his own lower nature to his own higher, and of himself for others. And life itself, it seems to him, would be too dearly bought, if purchased at the expense of another, however little or mean,-unless, indeed, of a kind irremediably noxious, whose extinction would benefit the world. For-be it remembered-though always Saviour, the Christ is sometimes also Purifier, as were all his types, the Heroes-or Men Regenerate-of classic story. Enacting, thus, when necessary the executioner's part, he slays for no self-gratification, but "in the name of the Lord."

19. They who have trod this path of old have been many, and their deeds have formed the theme of mystical legends innumerable. Epitomising these we find that the chief qualifications are as follows. In order to gain "Power and the Resurrection," a man must, first of all, be a Hierarch. This is to say, he must have attained the magical age of thirty-three years, having been, in the mystic sense of the terms, immaculately conceived, and born of a king's daughter; baptised with water and with fire; 
tempted in the wilderness, crucified and buried, having borne five wounds on the cross. He must, moreover, have answered the riddle of the Sphinx. To attain the requisite age, he must have accomplished the Twelve Labours symbolised in those of Heracles and in the signs of the Zodiac; passed within the Twelve Gates of the Holy City of his own regenerate nature; overcome the five Senses; and obtained dominion over the Four Elements. Achieving all that is implied in these terms, "his warfare is accomplished," he is free of Matter, and will never again have a phenomenal body.

20. He who shall attain to this perfection must be one who is without fear and without desire, save towards God; who has courage to be absolutely poor and absolutely chaste; to whom it is all one whether he have money or whether he have none, whether he have house and lands or whether he be homeless, whether he have worldly reputation or whether he be an outcast. Thus is he voluntarily poor, and of the spirit of those of whom it is said that they inherit the kingdom of heaven. It is not necessary that he have nothing; it is necessary only that he care for nothing. Against attacks and influences of whatever kind, and coming from whatever quarter without his own soul's kingdom, he must impregnably steel himself. If infortune be his, he must make it his fortune; if poverty, he must make it his riches; if loss, his gain ; if sickness, his health; if pain, his pleasure. Evil report must be to him good report ; and he must be able to rejoice when all men speak ill of him. Even death itself he must account as life. Only when he has attained this equilibrium is he "Free." Meanwhile he makes Abstinence, Prayer, Meditation, Watchfulness and Self-restraint to be the decades of his Rosary. And knowing that nothing is gained without toil, 
or won without suffering, he acts ever on the principle that to labour is to pray, to ask is to receive, to knock is to have the door open, and so strives accordingly.

2 I. To gain power over Death, there must be self-denial and governance. Such is the "Excellent Way," though it be the Via Dolorosa. He only can follow it who accounts the Resurrection worth the Passion, the Kingdom worth the Obedience, the Power worth the Suffering. And he, and he only, does not hesitate, whose time has come.

22. The last of the "Twelve Labours of Heracles" is the conquest of the three-headed dog, Cerberus. For by this is denoted the final victory over the body with its three (true) senses. When this is accomplished, the process of ordeal is no longer necessary. The Initiate is under a vow. The Hierarch is free. He has undergone all his ordeals, and has freed his will. For the object of the Trial and the Vow is Polarisation. When the Fixed is Volatilised, the Magian is Free. Before this, he is "subject."

23. The man who seeks to be a Hierarch must not dwell in cities. He may begin his initiation in a city, but he cannot complete it there. For he must not breathe dead and burnt air, - air, that is, the vitality of which is quenched. He must be a wanderer, a dweller in the plain and the garden and the mountains. $\mathrm{He}$ must commune with the starry heavens, and maintain direct contact with the great electric currents of living air and with the unpaved grass and earth of the planet, going bare-foot and of bathing his feet. It is in unfrequented places, in lands such as are mystically called the "East," where the abominations of "Babylon" are unknown, and where the magnetic chain between earth and heaven is strong, that the man who seeks Power, and who would achieve the "Great Work," must accomplish his initiation, 


\section{PART III.}

24. In assigning to the Gospels their proper meaning, it is necessary to remember that, as mystical Scriptures, they deal, primarily, not with material things or persons, but with spiritual significations. Like the "books of Moses," therefore, and others, which, in being mystical, are, in the strictest sense, prophetical, the Gospels are addressed, not to the outer sense and reason, but to the soul. And, being thus, their object is, not to give an historical account of the physical life of any man whatever, but to exhibit the spiritual possibilities of humanity at large, as illustrated in a particular and typical example. The design is, thus, that which is dictated by the nature itself of Religion. For Religion is not in its nature historical and dependent upon actual, sensible events, but consists in processes, such as Faith and Redemption, which, being interior to all men, subsist irrespectively of what any particular man has at any time suffered or done. That alone which is of importance, is what God has revealed. And therefore it is that the narratives concerning Jesus are rather parables founded on a collection of histories, than any one actual history, and have a spiritual import capable of universal application. And it is with this spiritual import, and not with physical facts, that the Gospels are concerned.

25. Such were the principles which, long before the Christian era, and under divine control, had led the Mystics of Egypt, Persia, and India, to select Osiris, Mithras, and Buddha as names or persons representative of the Man Regenerate and constituting a full manifestation of the qualities of Spirit. And it was for the same purpose and under the same impulsion that the Mystics of the West, who had their head-quarters at Alexandria, selected Jesus, 
using him as a type whereby to exhibit the history of all souls which attain to perfection ; employing physical occurrences as symbols, and relating them as parables, to interpret which literally would be to falsify their intended import. Their method was, thus, to universalise that which was particular, and to spiritualise that which was material; and, writing, as they did, with full knowledge of previous mystical descriptions of the Man Regenerate, his interior history and his relations to the world,-notable among which descriptions was the fifty-third chapter of the miscellaneous fragmentary prophetic utterances collected together under the typical name of Isaiah, - they would have had no difficulty in presenting a character consistent with the general anticipation of those who were cognisant of the meaning of the term "Christ," even without an actual example.

26. The failure to interpret the mystical Scriptures by the mystical rule, was due to the loss, by the Church, of the mystical faculty, or inner, spiritual vision, through which they were written. Passing under a domination exclusively sacerdotal and traditional, and losing thereby the intuition of things spiritual, the Church fell an easy prey to that which is the besetting sin of priesthoods,-Idolatry; and in place of the simple, true, reasonable Gospel, to illustrate which the history of Jesus had been expressly designed, fabricated the stupendous and irrational superstition which has usurped his name. Converted by the exaltation of the Letter and the symbol in place of the Spirit and the signification, into an idolatry every whit as gross as any that preceded it, Christianity has failed to redeem the world. Christianity has failed, that is, not because it was false, but because it has been falsified. And the falsification, generally, has consisted in removing the character described under the name of Jesus, from its true function 
as the portrait of that of which every man has in him the potentiality, and referring it exclusively to an imaginary order of being between whom and man could be no possible relation, even were such a being himself possible. Instead of recognising the Gospels as a written hieroglyph, setting forth, under terms derived from natural objects and persons, processes which are purely spiritual and impersonal, the Churches have-one and all-fallen into that lowest mode of fetish-worship, which consists in the adoration of a mere symbol, entirely irrespective of its true import. To the complaint that will inevitably be made against this exposition of the real nature of the Gospel history,-that it has "taken away the Lord,"-the reply is no less satisfactory than obvious. For he has been taken away only from the place wherein so long the Church has kept him, that is,the sepulchre. There, indeed, it is, with the dead,-bound about with cerements, a figure altogether of the past,-that Christians have laid their Christ. But at length the "stone" of Superstition has been lifted and rolled away by the hand of the Angel of Knowledge, and the grave it concealed is discovered to be empty. No longer need the soul seek her living Master among the dead. Christ is risen,-risen into the heaven of a living Ideal, whence he can again descend into the hearts of all who desire him, none the less real and puissant, because a universal principle, and not merely an historical personage; none the less mighty to save because, instead of being a single Man Regenerate, he is every Man Regenerate, ten thousand times ten thousand, -the "Son of Man" himself.

27. The name Jesus, or Liberator, belongs not to the man physical, - of his name and parentage the Gospels take no note,- but to the man spiritual, and is an initiation name denoting re-birth into a spiritual life. In this relation 
the man physical has no title to the name of Liberator, since the limitations from which man requires to be delivered can be overcome only by that which transcends the physical. Wherefore the name Jesus belongs to that in and by which liberation occurs, namely, the man's own regenerated selfhood; and whereas it is in and by means of this selfhood that he has emerged from a condition of spiritual death to one of spiritual life, it signifies to him a resurrection from the dead. Jesus is thus the name, not of one but of many, not of a person, but of an Order, the Order of regenerated Selfhoods, each of which is "Christ Jesus" in that it is the Saviour, through "Christ," of him in whom it is realised, though not all of these are Christs in the sense of being manifestations of Christ to the world. Paul alone of the Apostles clearly taught the doctrine of the subjective nature of the saving agency. His expression, "Christ in you the hope of glory," is inapplicable to any physical or extraneous personality. As a kabbalist and mystic, Paul was an evolutionist, and knew that the seed of every man's regeneration is within. Hence his exaltation of Christ as an interior principle, and his ability to recognise that method of the mystical Scriptures which consists in regarding man as a distinct personality in each successive stage of his unfoldment, and assigning to him a corresponding name. Adam, David, Jesus, are thus respectively the man "natural," being simply generate; the man "under grace," or partially regenerate, and therefore liable to serious lapses; and the man fully regenerate, and incapable of sin. Hence Paul's declaration that in the Adam stage of our development we all die, not having yet realised our saving principle; but in the Christ stage we all have eternal life. It was not, however, so much Paul's mysticism, as the sacerdotal guise in which he 
presented it, that brought him into conflict with the disciples.

28. Although the Gospels uniformly describe the miracles wrought by the Man Regenerate in terms derived from the physical plane, $\mathrm{He}$, as master of the spirits of all the elements, works miracles on all planes. Only those, however, which are referable to the spiritual plane have significance and value for the Soul. Hence for it the raising from the dead-as of Lazarus-implies resurrection from the condition of spiritual deadness; the giving of sight implies the opening of the spiritual vision; and the feeding of the hungry multitude implies the satisfaction of man's cravings for spiritual nourishment. The terms descriptive of the miracle last named afford one of the numerous indications of the influence of Greek ideas in the composition of the Gospels. For the "loaves" represent the doctrine of the lesser Mysteries whose "grain" is of the Earth, the kingdom of Demeter and of the outer. And the "fishes" - which are given after the loaves - imply the greater Mysteries, those of Aphrodite, - fishes symbolising the element of the "Sea-born" Queen of Love, whose dominion is the inner kingdom of the Soul. ${ }^{2}$ Similarly the conversion of water into wine implies the mysteries of Iacchos, the mystic name of the planet-God. The "beginning of miracles" for the Man Regenerate is always the transmutation of the "Water" of his own Soul into the "Wine" of the Divine Spirit. To these mysteries-which also were Egyptian, and there is reason to believe were enacted in the "king's and queen's chambers" of the Great Pyramidbelong also the "Acts" or "Crowns" which constitute for the Man Regenerate the "Week" of his New Creation, each being a "day" in that week. They are Baptism${ }^{2}$ See C.W.S., part ii., No. xiv. (1), pp. 266-269. 
called also Betrothal in view of the subsequent "Marriage": Temptation, or Trial: Passion: Crucifixion, or Death: Burial: Resurrection; and Ascension, the Sabbath, or Nirvâna, of perfection and rest, when - the "veil of the Temple" of the external self-hood having already been "rent from the top to the bottom"-he enters into the "Holy of Holies" of his now divine nature. All these Acts or Crowns-irrespective of any correspondence on the physical plane-denote indispensable processes enacted in the interior experiences of all who attain to full regeneration. From which it follows that the Gospel narrative, while related-in Scripture fashion-as of an actual particular person, and in terms derived from the physical plane-is a mystical history only of any person, and implies the spiritual possibilities of all persons. And hence, while using terms implying, or derived from, actual times, places, persons and events, it does not really refer to these or make pretence to historical precision, its function and purpose being, not to relate physical facts, which can have no relation to the soul, but to exhibit and illustrate processes and principles which are purely spiritual. Thus regarded, the Gospels-even though having in view a special personality as their model - constitute a parable rather than a history.

29. There is, moreover, a yet further explanation of the indifference to identity of detail by which everywhere this narrative is characterised. Being four in number, and disposed in order corresponding to that of the four divisions of man's nature, the Gospels have for standpoint, and bear relation to, different planes of the kosmos. Thus, the Gospel of Matthew, which represents the lower and physical plane, appeals more particularly on behalf of the character ascribed to Jesus of Nazareth as fulfilling the promises of the Messiah of the Old Testament, and is pervaded by one 
principle, the fulfilment in him at once of the Law and of the prophecies. The Gospel of Mark is adapted to the plane next above this, namely, the rational; its appeal on behalf of the divinity of the mission of Jesus being founded on the nature of his doctrine and works. The Gospel of Luke represents the further ascent to the plane of the soul and the intuition. Hence it occupies itself chiefly with accounts of the spiritual parentage of the Man Regenerate, - setting forth under a parabolic narrative his genesis from the operation of God in a pure soul. To the same end, this Gospel gives prominence to the familiar conversations, rather than to the formal teaching of its Subject, since it is in these that the affectional nature of a man is best manifested. In the fourth Gospel the scene changes to a sphere transcending all the others, being in the highest degree interior, mystic, spiritual. This Gospel, therefore, corresponds to the Nucleolus, or Divine Spirit, of the microcosmic entity, and exhibits the Regenerate Man as having surmounted all the elements exterior and inferior of his system, and won his way to the inmost recess of his own celestial kingdom, where, arrived at his centre and source, he and his Father are One; and he knows positively that God is Love, since it is by Love that he himself has found and become God. Such being the controlling idea of this Gospel, its composition is appropriately assigned to that "Beloved Disciple" whose very name denotes the feminine and love principle of existence. And to "John," surnamed "the Divine" in respect of the character thus ascribed to his ministry, is unanimously assigned the emblem of the Eagle, as representing the highest element in the human kingdom. With regard to the distribution of the other three symbols, it is obvious - when once the intention of each division of the Christian evangel is understood- 
that Matthew, who corresponds to the earth or body, is rightly represented by the Ox; Mark, the minister of the astral or fire, by the Lion; and Luke, whose pen is chiefly occupied with the relation of Christ to the Soul, by an Angel with the face of a man to denote the sea-god Poseidon, the "father of Souls." The Gospels are thus dedicated, each to one of the elemental spirits, Demeter, Hephaistos, Poseidon, and Pallas. Owing, however, to the loss by the Church of the doctrine which determines this distribution, much confusion and difference of opinion exist among ecclesiastical authorities with regard to the correct assignment of the elemental emblems. All the Fathers are agreed in giving the Eagle to the Fourth Gospeller, and but little doubt exists respecting the claim of Mark to the Lion; but the $O x$ and Angel have been generally misplaced in order.

\section{PART IV.}

30. Having defined the nature of the Man Regenerate and the relations represented in the Gospels as subsisting between him and the soul personified as the Virgin Mary, it remains still further to "declare his generation" by exhibiting the function fulfilled towards these two by the Mind, which is personified as Joseph, the Spouse of the Virgin and foster father of her Son. This is not the first appearance of Joseph in the Biblical presentation of the drama of the Soul. On the previous occasion he was in the vigour of youth, yet sufficiently matured intellectually and morally to be found worthy the highest posts of responsibility, and able to withstand the seductive sophistries of the materialistic philosophy-typified by the wife of Potiphar-of which "Egypt," the symbol of the lower nature, is always the seat. As also on his later appearance, he was emphatically a 
"just man," so that-it is written-the king set him over all the land and bid every one go to him and do all that he should direct. And under his guidance, Israel-who had followed him into Egypt, and to serve whom while there was his divinely appointed function-prospered exceedingly. But losing him, they sank into extreme misery, being enslaved and evil entreated of the Egyptians. ${ }^{8}$ On his reappearance in the Gospels, ${ }^{4}$ Joseph is still the "son of Jacob" and a "just man"; but of advanced maturity, yet possessed of energy and wisdom in measure to qualify him for the most difficult and delicate of tasks, that of guarding and guiding a pure and tender soul to the realisation of its highest aspirations, the production in its offspring of a character Divinely perfect. His task corresponded, indeed, to that assigned to the former Joseph, as the protector of the chosen of God; but the mode was changed, the level was higher, and the stage more advanced. The legend of the selection of Joseph to be the Spouse of the Virgin and foster father of her predicted Son, shows the quality of mind deemed requisite for such offices. For in representing his rod alone of those belonging to the candidates as blossom. ing, and the Holy Spirit as a dove settling upon it, the legend implies a mind-of which and its knowledges the rod is a symbol-competent for the perception of divine things and the suggestion of divine acts, and controlled, therefore, by the Divine Will. Only under the protection and governance of a mind thus conditioned can the soul become mother of man regenerate, - mother, that is, of God in man. And in order to show the supreme importance attached by it to the function of the Mind in this relation,

${ }^{3}$ See C.W.S., part ii., No. xiii. (1), pp. 257-260.

- As not persons but principles are here intended, there is no sug. gestion of a reincarnation of an individual. 
the Catholic Church speaks of St. Joseph as having "received all power necessary for the salvation of souls"; styles him an "Angel on earth," "King of Saints and Angels," and "third person of the earthly Trinity"; and declares that "after the dignity of Mother of God comes that of the foster father of God"; "after Mary comes Joseph";-expressions intelligible and appropriate as applied to the mind as a factor in the higher evolution of man; his redemption, that is, from his lower elements ; but not as applied to a person, be he whom he may. Nevertheless, the mind is only the putative, not the actual, father of the man regenerate. His exclusive parents are the Soul and Spirit, variously designated "Water and the Spirit," "Virgin Mary and the Holy Ghost." Being an entity purely spiritual, his parentage also is purely spiritual, and the mind has no more part in his generation than the body. Wherefore Joseph, who is not the builder of the house, but its fitter and furnisher, is not mason but carpenter.

3I. It is not only in virtue of his function of protector from Herod - who as the genius of the world's materialistic régime always is the destroyer of innocence-that Joseph takes the young child and his mother and flees into Egypt, but in virtue also of his function as educator. For in denoting the world and the body, Egypt denotes the lessons to be derived from both of these, the learning of which is indispensable to the soul's development. "There is Corn in Egypt. Go thou down into her, O my soul, with joy," says the man seeking regeneration, on every fresh return into earthly conditions ; "For in the kingdom of the Body thou shalt eat the bread of thine Initiation." He returns as an eager scholar to school. The ladder of evolution must be climbed painfully and with labour from the lowest step 
again and again, for each fresh branch of experience that is necessary for the soul's full development. For "there is no knowledge but by labour; no intuition but by experience." Heavenly things are unintelligible until earthly things have been mastered. Only when the aspirant is so firmly grounded and so far advanced as to have nothing more to fear from "Herod," who thus is virtually dead for him, can he return with safety to the land of Israel. And even there the mind must still be his guard and guide until by the attainment of his spiritual majority he passes into higher keeping. The parallel between the two Josephs is maintained to the last. Both are leaders of the chosen family into Egypt and their protectors while there. And of each the withdrawal is followed by danger and disaster. There is a profound significance in the date assigned for the death of the second Joseph. According to Christian tradition he remains with the Virgin and her Son, steadfastly exercising his functions towards them, until the latter is twenty-nine years of age. The age of full and final perfection for the man regenerate is-as already explained (par. 19)-the age of thirty-three, mystically computed, this im. plying his accomplishment of the thirty-three steps of initiation of which the last and highest is his "ascension" by transmutation, to final divine union. But the achievement of thirty steps fits him for his mission, by lifting him from the sphere wherein the mind is still necessary to him-the sphere of acquisition, reflection, and deliberation-to that wherein he is independent of processes of ratiocination,the sphere of direct perception and knowledge, inasmuch as he is thenceforth under a control exclusively divine, being "driven of the Spirit." At this juncture, therefore,-just as Jesus "begins to be about thirty years of age," Joseph dies, leaving him to enter upon the career which 
ends in his crucifixion, unimpeded by the prudential considerations which it is the province of the mind to suggest. In accounting Joseph the patron of a happy death, the Church implies the blissful satisfaction of a mind conscious of having made the interests of the Soul and her divine life, its supreme object.

32. Besides the state wherein the soul as Eve and immergent into materiality becomes the mother of man degenerate, and that wherein as Virgin Mary and exempt from materiality she becomes the mother of man regenerate, there is a third and intermediate state, an exposition of which is necessary to the full comprehension of the Gospels. This is the state of the soul during the period of her progress from Eve to Virgin Mary, while undergoing the experiences indispensable to such evolution. For the soul, no less than the man re-born of her, must be "perfected through suffering,"-the suffering involved in experiences profoundly felt and wisely applied. Hence her appellation "Sea of Bitterness." Only when she has exchanged the innocence that comes of ignorance, for the impeccability that comes of full knowledge, is she no longer in danger of relapse. Thenceforth there is for her son "no more sea."

Thus the very "sin" involved in the acquisition of experiences may itself be a means of redemption. Of these experiences the agent is always matter, this being at once the cause and the consequence of limitation of spirit. And whereas the soul's only true affinity and legitimate affection is Spirit-her own nature being spiritual-her intercourse with matter is mystically accounted an adultery, and she herself, during its continuance, is styled a "harlot." She may, nevertheless, in this her "fallen" state, retain and cherish the sense of her true nature and destiny, and 
eagerly anticipate the time when, freed from her association with materiality, and purged of her defilement, she will emerge white and spotless to claim her proper rank. That through which she will do this, will always be Love,-her love for the ideal she has kept alive, though latent, in her heart, even while descending to so low an actual. And for the sake of this Love, her sins-how many and grievous soever they may have been-will be forgiven her, and she herself in her turn will be dearly loved of Him-the Man Regenerate-since he will recognise in her past the indispensable prelude to his own present. And thus will she become ministrant to him of her substance,- - he unhesitatingly accepting, notwithstanding the mode of its acquisition; while the very passionateness of her nature, which has led to her past self-abandonment, serves but to endear her to him the more as betokening her capacity for selfsurrender in the opposite direction. And only by him are her acts of devotion towards him not deemed extravagant, because he, and he alone, comprehends their source and significance. The name given in the Gospels to the representative of the Soul in this state is Mary Magdalen, whom tradition identifies with Mary of Bethany. In the Old Testament, where she aids Israel to enter the promised land, she is termed Rahab, - a name which, signifying large or extended, may have been given her to imply that the soul which through weakness or fear shrinks from experiences, remains stunted and $\mathrm{dwarfed}$, and makes but a poor saving after all.

33. Herein lies the secret of the leniency and even tenderness exhibited by the typical Man Regenerate towards women of this class. Himself the representative of a perfection won through experience, he knows that the 
soul, of which Woman is the type, must have experiences. Himself the child of the soul, he heeds only the state of the soul, and views every act from the standpoint of the soul, caring only for the spirit in which it is performed. The conduct of Jesus in the case of the woman brought before him, when he reserved all his reprobation for her accusers, was but the reduction to practice of his denunciations of the chief priests and elders, "Verily, I say unto you, that the publicans and the harlots go into the kingdom of God before you." To ingrained impurity and hardness of heart, and to these alone, he is obdurate. Let a soul but be on the upward path, no matter at how low a point, and for Him it takes rank with the highest. He has already marked it for his own; it is one of his Elect.

34. They are, in their primary sense, various states of the soul which the Apocalypse describes under the guise of the Seven Churches of Asia Minor. And it is the soul hopelessly debased and reprobate which, under terms drawn from the Rome of the period, is denounced as the paramour of the "kings of the earth"-that is man's ruling propensities -and doomed to destruction together with that "Great City" which rests upon the "seven deadly sins" as Rome upon seven hills, the world's materialistic system.

35. Not only is the process of the soul's growth, education, and purification so slow and gradual as to require for its accomplishment the experiences of numerous earth-lives, it is also liable to be so unequal that, while far advanced in certain respects, in others it may be as far in arrears. And, meanwhile, these inequalities may find expression in anomalies and inconsistencies of character in the highest degree perplexing and distressing, combining in one and the same 
personality the opposite extremes of sage and simpleton, saint and sinner, a high moral character with dull intellectual faculties, or keen intellectual faculties with a total absence of moral perception; or, again, a high moral and intellectual nature with complete deprivation of spiritual perception. 'Thus irregularly developed, the same soul may subsist at once in all the stages enumerated, being simultaneously Eve, Magdalen, and Blessed Virgin, and manifesting in turn the charácteristics of each. Only when she is all Virgin Mary can she become mother of a man wholly regenerate. As sings the mystic poet already quoted,-

"I must become Queen Mary, and birth to God must give, If $I$ in blessedness for evermore would live." 5

36. We have yet to identify the persons represented in the Gospels as fulfilling at the Nativity the important function of recognition. These are the Magi, or "Wise men from the East," who hastened to render their homage and their offerings at the cradle of the Divine Infant. According to Catholic tradition, they were three in number, and were royal personages, a description which seems to identify them with the "kings of the East" of the Apocalyptic visions, whose habitat lies beyond the "great river Euphrates," and the way for whose coming requires to be specially prepared by the making of a ford across that river. Now the Euphrates is one of the "four rivers" of Genesis, already explained (Lecture VI., 6) as denoting the four constituent principles of the human kosmos. It is the Will ; in man unfallen, the Divine Will; in man fallen, the human will. The East is the mystical term for the source of heavenly light. "The glory of God came from the way 
of the East," says Ezekiel. Wherefore the "Kings of the East" are they who hold sway in a region lying beyond and above the "river" of the human Will, and only when that river is "dried up" can they approach man as heralds of the Divine Glory. Their function it is to announce the Epiphany of the Divine Life, to be the Sponsors for the Christ, the Godfathers of the heavenly Babe. To them it is appointed to discern him from afar off, and to hasten to affirm and declare him while yet in his cradle. Their offerings of gold, frankincense, and myrrh denote the recognition of the indwelling divinity by the prophetic, priestly, and regal attributes of man. Representing, respectively, the spirit, the soul, and the mind, they are symbolised as an angel, a queen, and a king; and they are, actually, Right Aspiration, Right Perception, and Right Judgment. The first implies enthusiasm for the glory of God and the advancement of souls, unalloyed by any selfish end. The second implies a vision for things spiritual, undimmed and undistorted by intrusion of elements material or astral. And the third implies the ability to "compare like with like and preserve the affinity of similars," so that things spiritual may not be confounded with things physical, but "to God shall be rendered the things of God, and to Cæsar the things of Cæsar."

37. But wherefore is it to a Cave and a Stable that the Star of the Understanding directs the steps of the Wise Men when seeking the birthplace of the Christ? Because, "In the elements of the Body is he imprisoned, lying asleep in the caves of Iacchos, in the crib of the Oxen of Demeter." $^{6}$. Because, that is, in constituting the culmination of the returning and ascending stream of emanation, - See C.W.S., part ii. (1), pp. 266-269. 
Christ is attained by evolution from the lowest:- "From the dust of the ground to the throne of the Most High."

38. An important factor in the education of the Man Regenerate is that described under the figure of John the Baptist. For he, too, is interior and mystic, inasmuch as he represents that all-compelling summons of the conscience to repentance, renunciation, and purification, which is the indispensable precursor of success in the quest after inward perfection.

39. The history of the Virgin Mary and her functions in regard to her Son, as presented alike in the Gospels and in Catholic tradition and ritual, are in every particular those of the soul to whom it is given to be "Mother of God" in man. Her acts and graces, as well as his life and passion, belong to the experience of every redeemed man. As the Christ in him delivers him from the curse of Adam, so the Virgin Mary in him delivers him from the curse of Eve, and secures the fulfilment of the promise of the conquest over the serpent of Matter. And, whereas, as sinner, he has seen enacted in his own interior experience the drama of the Fall; so, as saint, he enacts the mysteries represented in the Rosary of the Virgin, his soul passing in turn through every stage of her joys, her sorrows, and her glories. Wherefore the part assigned to Mary in the Christian Evangel is the part borne by the soul in all mystical experience. That which first beguiles and leads astray the soul is the attraction of the illusory world of mere phenomena, which is aptly represented under the figure of the Serpent with glittering coils, insinuating mien, and eyes full of fascination. Yielding to this attraction, through directing her gaze outwards and downwards instead of 
inwards and upwards, the soul-as Eve-has abandoned celestial realities for mundane shadows, and entangled in her fall the mind, or Adam. Thus mind and soul fall together and lose the power of desiring and apprehending the divine things which alone make for life, and, so, become cast out of divine conditions, and conscious only of material environments and liable to material limitations. This substitution of the illusory for the real, of the material for the spiritual, of the phenomenal for the substantial, constitutes the whole sin and loss of the Fall. Redemption consists in the recovery of the power once more to apprehend, to love, and to grasp the real. "Original sin," from which Mary is exempt, is precisely the condition of blindness which-owing to the soul's immergence in materialityhinders the perception of divine things. By no possibility can the Divine Life be generated in any soul afflicted with this blindness. Christ cannot be conceived save of a soul immaculate and virgin as to matter, and meet to become the spouse of the Divine Spirit. Therefore, as the soul as Eve gives consent to the annunciation of the Serpent, so, as Mary, become virgin, she gives consent to the annunciation of the Angel, and understands the mystery of the Motherhood of the man regenerate. She has no acts of her own, all the acts of her Son are hers also. She participates in his nativity, in his manifestation, in his passion, in his resurrection, in his ascension, in his pentecostal gift. He himself is her gift to the world. But it is always he who operates ; she who asks, acquiesces, consents, responds. Through her he outflows into the mind and external man, and, so, into life and conduct. As Augustine says, "All graces pass to us through the hands of Mary." For the purified soul is the mediatrix, as she is the genetrix, of the Divine presence. 
40. The Church speaks of the Ascension of Christ, and of the Assumption of Mary. Christ being deific in nature and of heavenly origin, ascends by his own power and will. But the soul is "assumed," or drawn up by the power and will of her Son. Of herself she is nothing; he is her all in all. Where he abides, thither must she be uplifted, by force of the divine union which makes her one with him. Henceforth she abides in the real, and has the illusions of sense for evermore under foot. It is not of herself that Mary becomes Mother of God in man. The narrative of the Incarnation implies a conjunction of human-though not physical-and Divine potencies. Mary receives her infant by an act of celestial energy overshadowing and vitalising her with the Divine life. This is because the pure soul is as a lens to the Divine rays, polarising them and kindling fire therefrom. Having this attitude towards God, she has kindled in her that holy flame which becomes the light that enlightens the world.

4I. The final state of the soul of the Man Regenerate is described in the Apocalypse under the figure of a marriage, wherein the contracting parties are the soul herself and the now Divine Spirit of the man, which is called the Lamb. The description of this Lamb as "slain before the foundation of the world," denotes the original and eternal act of self-immolation-typified in the Eucharist-whereby Deity descends into conditions and distributes of Itself to be the life and substance of the Universe, alike for its creation, its sustentation, and its redemption. In the crowning act of this stupendous drama-the act which mystically is called the "Consummation of the Marriage of the Son of God" - the Spirit and Bride, $\pi v \in \hat{v} \mu a$ and $v \dot{v} \mu \phi \eta$, as King and Queen of the perfected individuality, are indissolubly united ; 
and the human is taken up into the Divine, having received the "Gift of God," which is life eternal. Not merely a gift from God, although God is the giver; but a gift of God's own substantial Self, the infinite and eternal $I A M$ being individualised in him. As already shown, the initial and final stages of man's spiritual evolution are indicated by Paul when, read with the mystic sense, and translated into the eternal now, he says, " $\mathrm{He}$ is at first Adam, a living soul "-a soul having derived life; " $\mathrm{He}$ is at last Christ, a life-giving Spirit," or spirit that is itself Divine life. "In the former all die. In the latter all are made to live." From this it appears that the Bible sets forth the higher evolution - that is, the redemption, called also the new creation-of man, as a dual process occurring simultaneously in his two constituents, himself and his soul ; and whereas for the former and masculine moiety the first and last terms are, respectively, Adam and Christ; for the latter and feminine moiety they are Eve and Mary, called also the Bride.

\section{PART V.}

42. It was no part of the design of the Gospels to represent either the course of a man perfect from the first, or the whole course from the first of the man made perfect. Had they been designed to represent the former, they had contained no account of a Crucifixion. For, of the man perfect, no crucifixion, in the Mystical sense, is possible, since he has no lower self or perverse will, or any weakness, to be overcome or renounced, the anima divina in him having become all in all. That, therefore, which the Gospels exhibit, is a process consisting of the several degrees of regeneration, on the attainment of the last of which only does the man become "perfect." But of these 
successive degrees not all are indicated. For the Gospels deal, not with one whose nature is, at first, wholly unregenerate, but with one who is already, in virtue of the use made of his previous earth-lives, so far advanced as to be within reach, in a single further incarnation, of full regeneration.

43. For, owing to the complex and manifold nature of existence, every sphere or plane of man's being requires for itself a redemptive process; and, for each, this process consists of three degrees. Of these the first three relate to the Body, the second three to the Mind, the third three to the Heart, and the fourth three to the Spirit. There are thus, in all, twelve Degrees or "Houses" of the Perfect Man or Microcosm, as there are twelve Zodiacal Signs or Mansions of the Sun in his course through the heavens of the Macrocosm. And the Gospels set forth mainly the six of the Heart and Spirit. The crown both of the twelve degrees and of the six acts - that which constitutes alike the "Sabbath" of the Hebrews, the "Nirvâna" of the Buddhists, and the "Transmutation" of the Alchemists -is the "Divine Marriage." Of this, accordingly, types and parables recur continually in all Hermetic Scriptures. The last book of the Bible, the Apocalypse of John, fitly closes with a descriptive allegory of it. In this allegory the "Bride" herself is described as Salem, the Peace, or Rest, of God, a "city lying four-square," having Twelve Foundations and Four Aspects, all equal to each other, and upon every Aspect Three Gates. This heavenly Salem is, thus, the perfected Microcosm in whom is seen the At-one-ment of all the four planes, the physical, the intellectual, the moral, and the spiritual; the "Gates" of each side, or plane, symbolising the three degrees of Regeneration appertaining to each. And these twelve gates are described as being each of a single pearl, because, 
like pearls, the excellences denoted by them are attainable

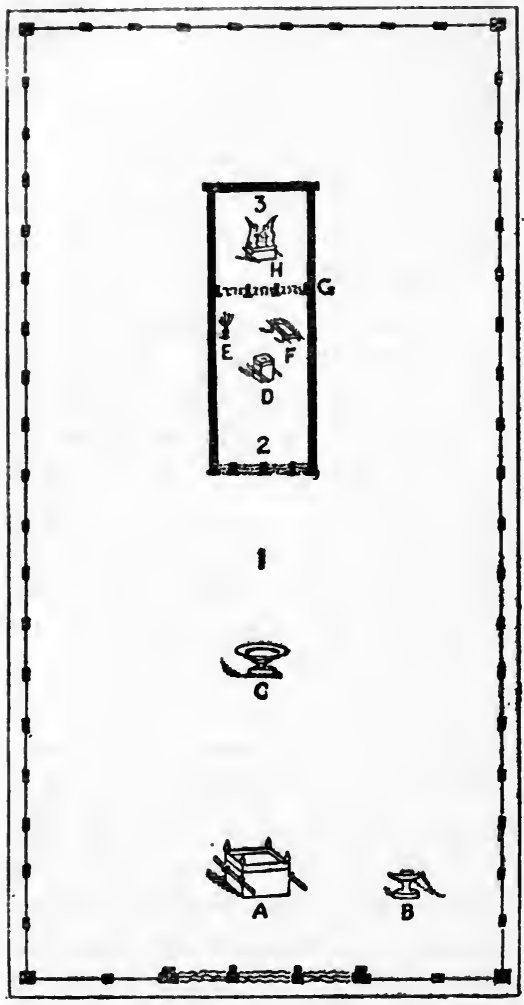

FIG, 2. - The Tabernacle in the Wilderness.

I, Open Court. 2, Holy Place-The Tent or Covered House. 3, Holy of Holies. A, Altar of Oblations. B, Censer. C, Laver. D, Altar of Incense. E, Golden Candlestick. F, Table of Shewbread. G, Veil dividing in two parts the Tent or Covered House. H, Ark of the Covenant containing the Rod, the Host, and the Law. the Ark and Shekinah. And in each of the four Deposit- only through skill and courage, and devotion even to the death, and require of those who would attain them the divestment of every earthly encumbrance.

44. The idea of this heavenly Salem is expressed also in the Tabernacle of Moses. For this, too, was fourfold. The Outer Court, which was open, denoted the Body or Man physical and visible; the covered Tent, or Holy place, denoted the Man intellectual and invisible; and the Holy of Holies within the veil, denoted the Heart or Soul, itself the shrine of the Spirit of the man, and of the divine Glory, which, in their turn, were typified by 
aries were three utensils illustrative of the regenerative degrees belonging to each division. The Marriage Supper, then, can be celebrated in the kingdom of the Father only, when all the "Twelve Apostles," or elements corresponding to the twelve degrees, have been brought into perfect harmony and at-one-ment, and no defective element any longer exists among them. In the central place at this divine feast is the 'Thirteenth Personage, the Master or Adonai of the system, the founder and president of the banquet. $\mathrm{He}$ it is who in later times found a representative in the pure and heaven-born Arthur, -Ar-Thor-the "Bright Lord" of the Round Table. For, as already stated, the number of the Microcosm is thirteen, the thirteenth being the occupant of the interior and fourth place, which, thus, he personifies, constituting the fourth and completing element, the Nucleolus of the whole cell or "Round Table." "And of this Fourth the form is as the Son of God." Thus the number thirteen, which on the earthly plane, and before the "Crucifixion," is, through the treachery of "Judas," the symbol of imperfection and ill-fortune, becomes, in the "Kingdom of the Father," the symbol of perfection. As the number of the lunar months, it is the symbol also of the Woman, and denotes the Soul and her reflection of God,-the solar number twelve being that of the Spirit. The two numbers in combination form the perfect year of that dual humanity which alone is made in the image of God,-the true "Christian Year," wherein the two-the inner and the outer, Spirit and Matter-are as one. Thirteen then represents that full union of man with God wherein Christ becomes Christ.

45. In representing the Regenerate Man as descended through his parents from the house of David and the tribe 
of Levi, the Gospels imply that man, when regenerate, is always possessed of the intuition of the true prophet, and the purity of the true priest, for whom "David" and "Levi" are the mystical synonyms. Thus the spiritual blood of prophet, priest, and king mingles in the veins of the Messiah and Christ, whose lineage is the spiritual lineage of every man regenerate, and attainable by all men.

46. For, as cannot be too clearly and forcibly stated, between the man who becomes a Christ, and other men, there is no difference whatever of kind. The difference is alone of condition and degree, and consists in difference of unfoldment of the spiritual nature possessed by all in virtue of their common derivation. "All things," as has repeatedly been said, "are made of the divine Substance." And Humanity represents a stream which, taking its rise in the outermost and lowest mode of differentiation of that Substance, flows inwards and upwards to the highest, which is God. And the point at which it reaches the celestial, and empties itself into Deity, is "Christ." Any doctrine other than this-any doctrine which makes the Christ of a different and non-human nature-is anti-christian and sub-human. And, of such doctrine the direct effect is to cut off man altogether from access to God, and God from access to man.

47. Such a doctrine is that which, representing the Messiah as an incarnated God or Angel who, by the voluntary sacrifice of himself, saves mankind from the penalty due for their sins, has distorted and obscured the true doctrine of atonement and redemption into something alike derogatory to God and pernicious to man.

That from which man requires to be redeemed, is not the penalty of sin, but the liability to sin. It is the sin, and not the suffering, which is his bane. The suffering is but the remedial agent. And from the liability to sin, and conse- 
quently to suffering, he can be redeemed only by being lifted into a condition in which sin is impossible to him. And no angel or third person, but only the man himself, co-operating with the God within him, can accomplish this. Man is, himself, the laboratory wherein God, as Spirit, works to save him, by re-creating him in God's image. But-as always happens under a control exclusively sacerdotal-religion has been presented as a way of escape, not from sin, but from punishment. With redemption degraded to this unworthy and mischievous end, the world has, as was inevitable, gone on sinning more and more, and, by the ever-increasing grossness of its life and thought, sinking itself deeper and deeper into Matter, violating persistently, on every plane of existence, the divine law of existence, until it has lost the very idea of Humanity, and-wholly unregenerate in Body, Mind, Heart, and Spirit-has reached the lowest depth of degradation compatible with existence. Thus, of modern society-as of Israel when reduced, through its own wickedness and folly, to the like evil plight--it may be said that "from the sole of the foot even unto the head, there is no soundness in it: but, wounds, and bruises, and putrefying sores." And even though "the whole head is sick, and the whole heart faint" at the view of its own hopeless theory of existence, it seeks to "revolt more and more" by becoming increasingly pronounced in its denial of Being as a divine Reality, and so does its utmost to "bring upon itself swift destruction." Such, to eyes in any degree percipient, is the spectacle presented by the world in this "Year of Grace," $188 \mathrm{r}$.

48. As it was no part of the design of the Gospels to represent the whole course of the Man Kegenerate, so neither was it a part of that design to provide, in respect 
of religious life and doctrine, a system whole and complete independently of any which had preceded it. Having a special relation to the Heart and Spirit of the Man, and thereby to the nucleus of the cell and the Holy of Holies of the Tabernacle, Christianity, in its original conception, relegated the regeneration of the Mind and Body-the covered House and open Court of the Tabernacle, or exterior dualism of the Microcosm-to systems already existent and widely known and practised. These systems were two in number, or rather were as two modes or expressions of the one system, the establishment of which constituted the "Message" which preceded Christianity by the cyclical period of six hundred years. This was the Message of which the "Angels" were represented in the Buddha Gautama and Pythagoras. Of these two nearly contemporary prophets and redeemers, the system was, both in doctrine and in practice, essentially one and the same. And their relation to the system of Jesus, as its necessary pioneers and forerunners, finds recognition in the Gospels under the allegory of the Transfiguration. For the forms beheld in this-of Moses and Elias-are the Hebrew correspondences of Buddha and Pythagoras. And they are described as beheld by the three Apostles in whom respectively are typified the functions severally fulfilled by Pythagoras, Buddha, and Jesus ; namely, Works, Understanding, and Love, or Body, Mind, and Heart. And by their association on the Mount is denoted the junction of all three elements, and the completion of the whole system comprising them, in Jesus as the representative of the Heart or Innermost, and as in a special sense the "beloved Son of God."

49. Christianity, then, was introduced into the world with a special relation to the great religions of the East, and 
under the same divine control. And so far from being intended as a rival and supplanter of Buddhism, it was the direct and necessary sequel to that system; and the two are but parts of one continuous, harmonious whole, whereof the later division is but the indispensable supplement and complement of the earlier. Buddha and Jesus are, therefore, necessary the one to the other; and in the whole system thus completed, Buddha is the Mind, and Jesus is the Heart; Buddha is the general, Jesus is the particular; Buddha is the brother of the universe, Jesus is the brother of men; Buddha is Philosophy, Jesus is Religion; Buddha is the Circumference, Jesus is the Within; Buddha is the System, Jesus is the Point of Radiation; Buddha is the Manifestation, Jesus is the Spirit; in a word, Buddha is the "Man," Jesus is the "Woman." But for Buddha, Jesus could not have been, nor would he have sufficed the whole man; for the man must have the Mind illuminated before the Affections can be kindled. Nor would Buddha have been complete without Jesus. Buddha completed the regeneration of the Mind; and by his doctrine and practice men are prepared for the grace which comes by Jesus. Wherefore no man can be, properly, Christian, who is not also, and first, Buddhist. Thus the two religions constitute, respectively, the exterior and interior of the same Gospel, the foundation being in Buddhism - the term including Pythagoreanism - and the illumination in Christianity. And as without Christianity Buddhism is incomplete, so without Buddhism Christianity is unintelligible. The Regenerate Man of the Gospels stands upon the foundation represented by Buddha, the earlier stages, that is, of the same process of regeneration, so that without these he would be impossible. Hence the significance, already explained, of the Baptist's part. 
50. The term Buddha, moreover, signifies the Word. And the Buddha and the Christ represent, though on different planes, the same divine Logos or Reason, and are joint expressions of the "Message" which, in preceding cycles, had been preached by "Zoroaster"-the Sun-staras well as by Moses, and typified in Mithras, Osiris, and Krishna. Of all these the doctrine was one and the same, for it was the doctrine of the Man Regenerate, even the "Gospel of Christ." It was, thus, the treasure-beyond all other priceless-of which Israel, fleeing, "spoiled the Egyptians"; of which, that is, the soul, escaping the power of the body, retains the possession, having gained it through its experience in the body. That Buddha, great as was his "Renunciation," underwent no such extremity of ordeal as that ascribed to his counterpart of the Gospels, is due to the difference of the parts enacted, and the stages attained, by them. Suffering is not of the mind, but of the heart. And whereas, of their joint system, Buddha represents the intellect, and Jesus represents the affections;in Jesus, as its highest typical expression of the loveelement, Humanity fulfils the injunction, "My son, give me thine heart." 7

5I. Since of the spiritual union in the one faith of Buddha and Christ, will be born the world's coming redemption, the relations between the two peoples through

7 This relation between the two systems, and the necessity of each to the other, have found recognition among the Buddhists themselves. Of this, one instance which may be cited, is that of a Cingalese chief who had sent his son to a Christian school; and who, on finding his consistency called in question by a Christian, replied that the two religions were to each other as the canoe of his country, and the contrivance-called an outrigger, -by means of which, when afloat, it is kept upright. "I add on," he said, "your religion to my own, for I consider Christianity a very good outrigger to Buddhism." - Tennant's Ceylon. 
whom, on the physical plane, this union must be effected, become a subject of special interest and importance. Viewed from this aspect, the connection subsisting between England and India rises from the sphere political to the sphere spiritual. As typical peoples of the West and of the East, of the races light and dark, these two, as representative Man and Woman of Humanity, will in due time constitute one Man, made in the image of God, regenerate and having power. And so shall the "lightning from the East," after "illuminating the West," be reflected back, purified and enhanced, "a light to lighten all nations and to be the glory of the spiritual Israel." Thus, then, in Christ Jesus the holy systems of the past find their maturity and perfectionment. For by Christ is made possible the gift of the Divine Spirit-the "Paraclete"-who could not come by Pythagoras nor by Buddha, because these represent the outer elements of the Microcosm; and the Nucleolus, or Spirit, can be manifest only in the inner element, or Nucleus, of which Jesus is the representative. And thus, as said in Genesis xv. 16, "in the fourth generation," shall the spiritual seed of Abraham, or Brahma-for they are one and the same word and denote one and the same doctrine-" "return" to the promised land of their inheritance; and, as said by Jesus, "many shall come from the East and West, and shall sit down with Abraham, and Isaac, and Jacob, in the kingdom of heaven."

52. For, as the "three, Noah, Daniel, and Job," were for the Hebrews, types of Righteousness, so the three, "Abraham, Isaac, and Jacob," were types of 'Truth, progenitors of the spiritual Israel, and representatives of the several sacred mysteries of whose "kingdom" the Man Regenerate is always, and the world regenerate will be ultimately, by adoption and grace, the inheritor. The 
mysteries specially denoted by "Abraham" are, as just indicated, those of India. They are the mysteries of the Spirit, or Innermost, and are sacred to the Supreme Being, Brahma, who represents Deity under process of self-manifestation and, therefore, in activity. In this process, the Original Being, Brahm, becomes Brahma; God becomes the Lord, the Manifestor. And it is in recognition of this change, that Abram becomes Abraham. The history of this personage, his flight,-always an invariable element in such histories, as witness that of Bacchus, of Israel, of the Holy Family, of Mohammed, and others,- - his adventures and wanderings, is the history of the migration of the mysteries of India, by way of Chaldæa, to that divinelyselected centre and pivot of all true religions, Egypt,-a term denoting the body, which itself is the divinely-appointed residence of the soul during its term of probation. ${ }^{8}$ The next great order of mysteries refers to the soul, and is sacred to Isis, the goddess of the intuition, and "Mother" of the Christ. These mysteries were, for the Israelites, represented by 1 saac, a name occultly connected with Isis and Jesus, as also with that of an important personage in the pedigree of this last, namely Jesse, the "father of David," and a "keeper of sheep." The third and remaining great

${ }^{8}$ In accordance with Hindu usage, which makes the musculine the passive, and the feminine the active principle of existence, the mysteries are represented by the wives of the divine persons. Thus, of Brahma the active principle is his wife Saraszuati, after whom the wife of Abraham, who is also his active principle, is called Sara, "the Lady," meaning, of heaven. The story of the long courtship and two wives of Jacob, is a parable of initiation into the mysteries, lesser and greater. And the finding of the wife of Isaac at a well-like the finding of Moses in a river by the king's daughter-indicates the woman, or soul, as the agent of intuition, and thereby of initiation and redemption. The "Haran" and "Ur" from which Abram comes, denote the place of spiritual light; and the pedigrees imply primarily, not persons, but spiritual states. 
order of the mysteries-that which refers to the body, and which early migrated to Greece - is sacred to Bacchus, whose mystic name Iacchos is identical with Jacob. Comprising the three great divisions of existence, and by implication the fourth division also, these three combined orders of mysteries formed, in the original conception of Christianity, a system of doctrine and life at once complete, harmonious, and sufficient for all needs and aspirations of humanity, both here and hereafter. And to this effect were the terms ascribed to Jesus in his reply to the inquiries made of him touching the resurrection of the dead. For, passing over the actual question, and coming at once to its mystic sense, he made a reply which referred, at least primarily, not to the individuals themselves who had been named, but to the systems implied in their names; and declaring those systems to be as full of vitality, and as essential to salvation, as when first divinely communicated to Moses in the words: "I am the God of Abraham, and the God of Isaac, and the God of Jacob," he added that "God is not the God of the dead, but of the living." Wherefore, according to this and the concurrent prophecy quoted above, these mysteries-which are at once Hinda, Chaldæan, Persian, Egyptian, Hebrew, Greek, and Christian-will, restored to their original purity, constitute the controlling doctrine of the ages to come.

53. In this forecast of the now imminent future is to be found the clue to the world's spiritual politics. Transferred from the mystical to the mundane plane, the "kings of the East " are they who hold political sovereignty over the provinces of Hindustan. On the personal plane the title implies those who possess the "magical" knowledge, or keys of the kingdom of the Spirit, to have which is to be Magian. In both these senses the title henceforth belongs 
to us. Of one of the chief depositories of this magical knowledge - the Bible-our country has long been the foremost guardian and champion. For three centuries and a half - a period suggestive of the mystic "time, times, and half a time," and also of the "year of years" of the solar hero Enoch-has Britain lovingly and faithfully, albeit unintelligently, cherished the Letter which now, by the finding of the interpretation, is-like its prototype- "translated" to the plane of the Spirit. Possessing thus the Gnosis, in substance as well as in form, our country will be fitted for the loftier, because spiritual, sovereignty to which she is destined, and one which will outlast her material empire. For, finding then that they are essentially one as to faith and hope, even though diverse in respect of accidentals, the East and the West will be one in heart and aim, and together beget as their joint offspring the philosophy, morality, and religion, in a word, the Humanity, of the future. All, therefore, that tends to bind England to the Orient is of Christ, and all that tends to sever them is of Antichrist. They who seek to wed Buddha to Jesus are of the celestial and upper; and they who interpose to forbid the banns are of the astral and nether. Between the two hemispheres stand the domain and faith of Islam, not to divide, but, as umbilical cord, to unite them. And nought is there in Islamism to hinder its fulfilment of this high function, and keep it from being a partaker of the blessings to result therefrom. For, not only is it the one really monotheistic and non-idolatrous religion now existing; but its symbolic Star and Crescent are essentially one with the Cross of Christ, in that they also typify the elements masculine and feminine of the divine existence, and the relation of the soul to God. So that Islamism has but to accomplish that other stage of its natural evolution, which will enable it 
to claim an equal place in the brotherhood of the Elect. This is the practical recognition in "Allah" of Mother as well as of Father, by the exaltation of the woman to her rightful station on all planes of man's manifold nature. This accomplished, Esau and Ishmael will be joined together with Abraham, Isaac, and Jacob, in Christ.

54. In this recognition of the divine idea of humanity, and its ultimate results, will consist what are called the "Second Advent and millennial reign of Christ." Of that advent-although described as resembling the coming of a thief in the night-the approach will not be unheeded. For, even in the darkest of spiritual nights, there are always on the alert some who, as faithful shepherds, keep constant watch over the flocks of their own pure hearts, and who, "living the life, know of the doctrine." And these, "dwelling by the well of clear vision," and " discerning the signs of the times," perceive already the mustering of the heavenly hosts, and the bright streamers of dawning of the long wished-for better Day. ${ }^{9}$

- See C.W.S., part i., No. xi., p. 36, and part ii., Nos. v., p. 224, and ix., p. 234. 


\section{LECTURE THE NINTH. ${ }^{1}$}

GOD AS THE LORD; OR, THE DIVINE IMAGE.

\section{PART I.}

1. All sacred books, of whatever people, concur in adopting in respect of the Deity two apparently opposite and antagonistic modes of expression. According to one of these modes, the Divine Being is eternal, universal, diffused, unformulated, indefinable, and altogether inaccessible and beyond perception. According to the other, the Divine Being is near, particular, definite, formulated, personified, discernible, and readily accessible. Thus, on the one hand, it is said that God is the high and holy One that inhabiteth eternity, and is past finding out ; that no man hath seen God at any time, neither heard God's voice, or can see God and live. And, on the other hand, it is declared that God has been heard and beheld face to face, and is nigh to all who call upon God, being within their hearts; and that the knowledge of God is not only the one knowledge worth having, but that it is open to all who seek for it; and the pure in heart are promised, as their supreme reward, that they shall "see God."

This lecture was written by Edward Maitland, with the exception of portions of paragraphs 20-23, which were written by him and Anna Kingsford jointly, and paragraphs 44-46, 53 and 54, which were compiled from Revelations to Anna Kingsford ; and was delivered by him on Monday the I8th July, I881 (Life of $A . K$., vol. ii., pp. 16, 17, 32). 
2. Numerous instances, 1 ,oreover, are recorded of the actual sensible vision of $\mathrm{C}$ d. Of the Hebrew prophets, Isaiah says that he saw $t$ ' 2 Lord "high and lifted up"; Ezekiel, that he beheld th "glory of the God of Israel" as a figure of fire; Daniel, nat he beheld God as a human form, enthroned in flamt; and John records in the Apocalypse a similar vision. The writers of the book of Exodus show their cognisance o! such experiences by ascribing the vision not only to Moses, but to the whole of the elders and leaders of Israel, in all, seventy-four persons. And of these many are represented as competent to receive it in virtue of their own unaided faculties. For, by the statement that "upon the nobles Moses laid not his hands," it is implied that their own spiritual condition was such that they needed no aid from the magnetism of the great hierarch their chief. The sight of the "God of Israel" on this occasion is described as like that of "a devouring fire."

3. Among similar experiences related in other Scriptures is that in the Bhagavad Gitâ, wherein the "Lord Krishna" exhibits to the gaze of Arjun his "supreme and heavenly form" "shining on all sides with light immeasurable, like the sun a thousand-fold," and "containing in his breast all the Gods, or Powers, masculine and feminine, of the Universe."

4. Yet, notwithstanding the difference of the two natures thus described, the Scriptures regard both as appertaining to one and the same Divine Being; and, combining the names characteristic of both, declare that the Lord is God, and God is the Lord, and appoint the compound term Lord-God as the proper designation of Deity.

5. Besides the title Lord, many various names are applied to Deity as subsisting under this mode. In the Jewish and Christian Scriptures these names are Jehovah, 
El Shaddai, the Logos, the Ancient of Days, Alpha and Omega, Son of God, the Only Begotten, Adonai. The Hindus have Brahma, and also Ardha-Nari,-identical with Adonai. The Persians, Ormuzd; the Egyptians, Ra, or the Sun; the Greeks, the Demiourgos; the Kabbala has Adam Kadmon; and some later mystics employ the term "Grand Man."

6. Of these last the most notable, Emanuel Swedenborg, asserts the vision to be a fact in respect of the angels, -whom he claims as his informants, - saying that the Lord is God manifested in the universe as a man, and is thus beheld, interiorly, by the angels. (Divine Love and Wisdom, 97 , etc., etc.)

7. Swedenborg, however, identifies the Lord who is thus discerned with the historical Jesus, maintaining the latter to be very Deity, Jehovah in person, who assumed a fleshly body, and manifested Himself as a man, in order to save men from hell, and commanded His disciples to call Him Lord. (True Christian Religion, 370; D. L. and W., 282, etc., etc.) Swedenborg herein falls into the common error of confounding "our Lord " with "the Lord," the Christ in the man with Adonai in the heavens, of whom the former is the counterpart; -an error due to his failure to recognise the distinction between the manifest and the unmanifest, and between the microcosmic and the macrocosmic deity. ${ }^{2}$

2 In his presentation of the Incarnation, Swedenborg is at variance, not only with the Gnosis, but with himself. For in it he sets aside the canon of interpretation formulated by himself, his recovery and general application of which-together with the doctrine of correspondenceconstitute his chief merit. Thus, to cite his own words:- "In the internal sense there is no respect to any person, or anything determined to a person. But there are three things which disappear from the sense of the letter of the Word, when the internal sense is unfolded; that which is of time, that which is of space, and that which is of person." "The Word is written by mere correspondence, and hence all its contents, to the most minute, signify things heavenly and spiritual" 
8. In "the Lord" the Formless assumes a form, the Nameless a name, the Infinite the definite, and these human. But, although " the Lord is God manifested as a man" in and to the souls of those to whom the vision is vouchsafed, it is not as man in the exclusive sense of the term and masculine only, but as man both masculine and feminine, at once man and woman, as is Humanity itself. The Lord is God manifested in substance, and is dual in form because Deity, though one in essence, and statically, is twofold in operation, or dynamically. And the vision of Deity under a definite form, dual and human,-or androgynous, though not as ordinarily apprehended,- - has been universal and persistent from the beginning; and this, not

(Arcana Colestia, 5253 and 1401). He also repeatedly declares that the literal sense of the Word is rarely the truth, but only the appearance of the truth, and that to take the literal sense for the true one is to destroy the truth itself, since everything in it relates to the heavenly and spiritual, and becomes falsified when transferred to a lower plane by being taken literally (see e.g. T. $C . R ., 254,258$, etc.). According both to this rule and the Gnosis, that which is implied by the term Incarnation is an event purely spiritual in its nature, potential in all men, and of perpetual occurrence, inasmuch as it takes place in every regenerate man, being at once the cause and effect of his regeneration.

The authority twice cited by Swedenborg $(T, C . K ., 102$ and 827) in support of his doctrine, - namely, an apparition professing to be the spirit of the Mother of Jesus, - is one which a duly instructed occultist would, at the least, have hesitated to regard as aught but a projection of his own magnetic aura, and as merely a mechanical reflect, therefore, of his own thought. Swedenborg had learned little or nothing from books, was ignorant of any system other than the Christian, and also of the origin and meaning of the Christian symbology, and trusted for his information entirely to his own faculty ; and this, extraordinary as it was, was allied to a temperament too cold and unsympathetic to generate the enthusiasm by which alone the topmost heights of per. ception and inmost core of the consciousness can be attained. Nevertheless, despite his limitations, Swedenborg was beyond question the foremost herald and initiator of the new era opening in the spiritual life of Christendom, and no student of religion can dispense with a knowledge of him. Only, he must be read with much discrimination and patience. 
as a conception merely mental and "subjective," but as a perception objective to an interior faculty, in that it is actually beheld. Hence it is that, in terms employed to denote Deity, both sexes are expressed or implied; and where one sex only is designated, it is not because the other is wanting, but because it is latent. And hence it is also, that, in order to be made in the image of God, the individual must comprise within himself the qualities masculine and feminine of existence, and be, spiritually, both man and woman. Man is perfect only when the whole humanity is manifested in him; and this occurs only when the whole Spirit of Humanity - that is God-is manifested through him. Thus manifesting Himself, God, as the book of Genesis says, "creates man in His own Image, Male and Female."

9. Such is the doctrine of all Hermetic Scriptures. And when it is said-as of the Kabbala-that these Scriptures were delivered by God first of all to Adam in Paradise, and then to Moses on Sinai, it is meant that the doctrine contained in them is that which man always discerns when he succeeds in attaining to that inner and celestial region of his nature where he is taught directly of his own Divine Spirit, and knows even as he is known. The attainment of this divine knowledge constitutes existence a paradise. And it is symbolised by the ascent of a mountain, variously designated Nyssa, Sinai, Sion, Olivet. Peculiar to no particular period or place, the power to receive this knowledge is dependent entirely upon condition. And the condition is that of the understanding. Man attains to the Image of God in proportion as he comprehends the nature of God. Such knowledge constitutes, of itself, transmutation. For man is that which he knows. And he knows only that which he $i$. Wherefore the recognition, first of God as the Lord, and next of the Lord as the divine 
Humanity, constitutes at once the means of salvation and salvation itself. This is the truth which makes free,- the supreme mystery, called by Paul the "mystery of godliness." And it is by their relegation of this mystery to the category of the incomprehensible, that the priesthoods have barred to man the way of redemption. They have directed him, indeed, to a Macrocosmic God subsisting exteriorly to man, and having a nature altogether different from man's, and to a heaven remote and inaccessible. But they have suppressed altogether the Microcosmic God and the kingdom within, and have blotted the Lord and his true image out of all recognition. Now the main distinction between the uninitiate and the initiate, between the man who does not know and the man who does know, lies in this:-For the one, God, if subsisting at all, is wholly without. For the other, God is both within and without ; and the God within is all that the God without is.

10. It cannot be too emphatically stated, that the definition which sets forth Mystery as something inconsistent with or contradictory of sense and reason, is a wrong definition, and one in the highest degree pernicious. In its true signification, Mystery means only that which appertains to a region of which the external sense and reason are unable to take cognisance. It is, thus, the doctrine of Spirit and of the experiences connected therewith. And inasmuch as the spiritual is the within and source of the phenomenal, so far from any doctrine of Spirit contradicting and stultifying the experiences and conclusions of the external faculties, it corrects and interprets them;-precisely as does reason correct and interpret the sensible impression of the earth's immobility, and of the diurnal revolution of the skies. That, therefore, which the degradation of the term Mystery to mean something incomprchensible, really 
represents, is the loss by the priesthoods of the faculty of comprehension. Declining, through "idolatry," from the standard once attained by them, and losing the power either to discern or to interpret Substance, the Churches abandoned the true definition of Mystery which referred it to things transcending the outer sense and reason, and adopted a definition implying something contradictory of all sense and reason. Thenceforth, so far from fulfilling their proper function of supplying man with the wholesome "bread" of a perfect system of thought, they gave him instead the indigestible "stones" of dogmas altogether unthinkable; and for the "fish,"-or interior mysteries of the soul,- the "serpents," or illusory reflects, of the astral. Reduced by this act to a choice between the suicide of an absolute surrender of the reason, and open revolt, the world adopted the lesser of the two evils. And this both rightly and of necessity. For man neither ought if he could, nor can if he would, suppress his reason. And now the Churches, having lost the cognition of Spirit, and suppressed the faculty whereby alone it could be attained, are absolutely without a system of Thought wherewith to oppose the progress of that fatal system of No-thought which is fast engulfing the world. And so profound is the despair which reigns even in the highest ranks of Ecclesiasticism, as recently, from one of its most distinguished members, to elicit the confession that he saw no hope for Religion save in a new Revelation. ${ }^{3}$

\section{PART II.}

II. It is necessary to devote a brief space to an exposition of the ancient and true doctrine in respect of the place

${ }^{3}$ Related of Cardinal Newman, on his investiture at Rome. He was made a cardinal by Leo XIII. in 1879, and died in 1890. 
and value of the Understanding in things religious. For so we shall both further minister to the rehabilitation of this supreme faculty, and exhibit the extent to which sacerdotalism has departed from the right course. Mention has already been made of Hermes as the "trainer of the Christs." The phrase is of a kind with those more familiar phrases which describe Christ as the "Son of David" and as the "Seed of the Woman"; and, in short, with all statements respecting the genealogy of the Christ, including the declaration that the Rock on which the Church of Christ is built is the Understanding. For of all such statements the meaning is, that the doctrine represented by the term Christ-so far from being a Mystery, in the sacerdotal sense-is a truth necessary and self-evident, and requiring for its discernment as such, only the full and free exercise of Thought. Now, this term Thought is no other than the name of the Egyptian equivalent of Hermes, the God Thaut, frequently written Thoth; these being for the Greeks and Egyptians respectively the Divine Intelligence in its dynamic condition. It has already been stated that in the Celestial all properties and qualities are Persons, the fact being that it is always in the guise of a person that the Divine Spirit of a man holds intercourse with him, the mode adopted on the occasion corresponding to the function to be exercised. Thoth and Hermes are, then, names expressive of the personality assumed by the supreme Nous of the Microcosm when operating especially as the Intelligence or Understanding. In different nations, while the function is the same, the name and form vary according to the genius of the people. Thus, to a Hebrew the same Spirit becomes manifest as Raphael. In the Bhagavad-Gita the Supreme Being, speaking as the Lord (Krishna), declares that he himself is the Spirit of Under- 
standing. As the parent Spirit-the Nous, or divine Mind -is God, so the product Thought, or the "Word," as a Son of God, is also God. Nor does the Divine procession cease at the first generation. For, whereas of such Divine Word the Christ is the manifestation "in ultimates," the Christ also is Son of God, and therefore God.

I 2. But not the less, however, is "Christ" the "Son of David," though not by physical descent-his line had long been extinct-but in a spiritual sense. Like the patriarchs -who were therefore said to live in concubinage-David was not "married to the Spirit," but held only occasional communion with it, receiving but a measure of illumination. "Christ" implies full regeneration and illumination. The attainment of this state is the ultimate aim of the science called Hermetic and Alchemic, the earliest formulation of which is ascribed to the god Thoth,-the Egyptian equivalent for the Divine Thought. Tracking the Christ-idea to this source, we have a yet further-though still but a secondary-signification for the saying, "Out of Egypt hast thou called thy Son."

13. One of the most general symbols of the Understanding, and of its importance in the work of regeneration, has always been the Ram. Hence the frequent portrayal of the representative of Hermes and Thoth with a ram's head. For by this was denoted the power of the faculty of which the head is the seat, the act of butting with the horns typifying the employment of the intellect whether for attack or defence. The command to cover the holy place of the Tabernacle with a ram's fleece, implied that only to the understanding were the mysteries of the Spirit accessible. The mighty walls of the "Jericho" of Doubt, are represented as falling at the sound of rams' horns, after being "encompassed" during the typical period of seven days. 
The narrative of the previous entry-that of the "spies"into this stronghold through the agency of a woman, is similarly designed to exalt the understanding, the direct reference being to the intuition as essential to the understanding, and therefore to the resolution of doubt. The ascription to this woman of the vocation of the Magdalen, accords with the mystical usage of regarding the soul as impure during the term-necessary for her education - of her association with Matter. This finished, she becomes "virgin." One of the chief glories of Hermes-his conquest of the hundred-eyed Argus-denotes the victory of the understanding over fate. For Argus represents the power of the stars over the unenfranchised soul. Wherefore Hera, the queen of the astral spheres and persecutrix of the soul thus subject, is said to have placed the eyes of Argus in the train of her vehicular bird, the peacock.

14. The story of the slaying of Goliath is a parable of like import. For Goliath is the formulation of the system represented by the "Philistines,"-that system of doubt and denial which finds its inevitable outcome in Materialism. The killing of Goliath signifies, thus, the discomfiture of Materialism by the Understanding. And David, moreover, is represented-on arraying himself for the conflictas declining the "king's weapons," or arms of the exterior reason, and choosing "a smooth stone out of a brook"; this being the "philosopher's stone" of a pure spirit, a firm will, and a clear perception, such as is attained only through the secret operation of the soul, of which the brook is the emblem. Such a stone, also, is that which, "cut out without hands," smites in pieces, as already explained, the giant image of Nebuchadnezzar. The reward of David's achievement-the possession of the king's daughter, the 
usual termination of such heroic adventure-denotes the attainment by the conqueror of the highest gifts and graces; -the daughter of Saul, or the outer Reason, being the inner Reason, or psychic faculty, developed from the "Man," and constituting the "Woman" in the man. Hence by David's subsequent history in relation to Michal, is implied a spiritual retrogression on the soul's part.

15. Similar reasons dictated the selection of a dog as specially sacred to Hermes, and his representation as the dog-headed Anubis; the intelligence and faithfulness of this animal making it an apt type of the understanding as the peculiar friend of man. Raphael-the Hebrew equivalent of Hermes, and like him called the "physician of souls"is also represented as accompanied by a dog when travelling with Tobias. And the name of the special associate of Joshua, - a name identical with Jesus, - the final leader of the chosen people into the promised land of their spiritual perfection,-namely, Caleb, signifies a dog, and implies the necessity of intelligence to the successful quest of salvation. For the like reason were "rams," and the "fat of rams," used as symbolic terms to denote the offering most acceptable to God. It was intended by them to teach that man ought to dedicate to the service of God all the powers of his mind raised to their highest perfection, and by no means to ignore or suppress them.

I6. The like high rank is accorded to the Understanding in all Hermetic Scriptures. For,-as in Isaiah xi. 2,-it is always placed second among the seven Elohim of God, the first place being assigned to Wisdom, which is accounted as one with Love. The same order is observed in the disposition of the solar system. For Mercury is Hermes, and his planet is next to the Sun. The ascription, in the 
mythologies, of a thievish disposition to this divinity, and the legends which represent him as the patron of thieves and adventurers, and stealing in turn from all the Gods, are modes of indicating the facility with which the understanding annexes everything and makes it its own. For Hermes denotes that faculty of the divine part in man which seeks and obtains meanings out of every department of existence, intruding into the province of every "God," and appropriating some portion of the goods of each. Thus the understanding has a finger upon all things, and converts them to its own use, whether it be the "arrows" of Apollo, the "girdle" of Aphrodite, the "oxen" of Admetus, the "trident" of Poseidon, or the "tongs" of Hephaistos. Not only is Hermes-as already said-the rock on which the true Church is built; he is also the divinity under whose immediate control all divine revelations are made, and all divine achievements performed. His are the rod of knowledge wherewith all things are measured, the wings of courage, the sword of the unconquerable will, and the cap of concealment or discretion. $\mathrm{He}$ is in turn the Star of the East, conducting the Magi ; the Cloud from whose midst the holy Voice speaks; by day the pillar of Vapour, by night the shining Flame, leading the elect soul on her perilous path through the noisome wilderness of the world, as she flies from the Egypt of the Flesh, and guiding her in safety to the promised heaven. $\mathrm{He}$, too, it is who is the shield of saints in the fiery furnace of persecution or affliction, and whose "form is like the Son of God." And by him the candidate for spiritual knowledge attains full initiation. For he is also the Communicator, and without him is no salvation. For, although that which saves is faith, that is not faith which is without understanding. Happily for the so-called "simple," this understanding is 
not necessarily of the outer man; it suffices for salvation that the inner man have it. ${ }^{4}$

17. "Hermes, as the messenger of God," says the Neoplatonist Proclus, "reveals to us his paternal will, and - developing in us the intuition-imparts to us knowledge. The knowledge which descends into the soul from above, excels any that can be attained by the mere exercise of the intellect. Intuition is the operation of the soul. The knowledge received through it from above, descending into the soul, fills it with the perception of the interior causes of things. The Gods announce it by their presence, and by illumination, and enable us to discern the universal order." Commenting on these words of a philosopher regarded by his contemporaries with a veneration approaching to adoration, for his wisdom and miraculous powers, a recent leader of the prevailing school exclaims, "Thus is Proclus consistent in absurdity!" 5 Whereas, had the critic been aware of the truth concerning the reality, personality, and accessibility of the world celestial, so far from denouncing Proclus as "absurd," he would have supremely envied him, and eagerly sought the secret and method of the Neoplatonists. "To know more," says the writer in question, "we must be more." But when the Mystic-who, in virtue of his supreme sense of the dignity and gravity of man's nature, affirms nothing lightly or rashly-offers his solemn assurrance that we are more, and prescribes a simple rule, amply verified by himself, whereby to ascertain the fact, he turns away in disdain, and proceeds in his own manner to make himself infinitely less, by becoming a ringleader of that terrible school of Biology, which does not scruple, in the outraged name of Science, to indulge its passion for know-

4 See C.W.S., part ii., Nos. xii., pp. 245-247 ; and xiii. (6), p. 257.

${ }^{3}$ G. H. Lewes, Biog. Hist. Phil. 
ledge to the utter disregard of humanity and morality, by the infliction of tortures the most atrocious and protracted, upon creatures harmless and helpless. Little wonder is it that between Mystic and Materialist should gulf so impassable, feud so irreconcilable, intervene; seeing that while the one seeks by the sacrifice of his own lower nature to his higher, and of himself for others, to prove man poten. tial God, the other-turning vivisector-makes him actual fiend. ${ }^{6}$

18. To resume our exposition of the "mystery of godliness," or doctrine of God as the Lord, and of the duality of the Divine image. According to the Zohar-the prin. cipal book of the Kabbala - the Divine Word by which all things are created is the celestial archetypal Hunanity, which-subsisting eternally in the Divine Mind-makes the universe in His own image. God, as absolute Being, having no form or name, cannot and may not be represented under any image or appellation. Bent upon selfmanifestation, or creation, the Divine Mind conceives the Ideal Humanity as a vehicle in which to descend from Being into Existence. This is the Merkaba, or Car, already referred to; and that which it denotes is Human Nature in its perfection, at once twofold in operation, fourfold in constitution, and sixfold in manifestation, and as a cube-Kaabeh-" standing four-square to all the winds of heaven." In virtue of its twofoldness this "vehicle" expresses the corresponding opposites, Will and Love, Justice and Mercy, Energy and Space, Life and Substance,

6 This paragraph was written with a view to its publication in the life-time of Mr. Lewes. Unhappily, the necessity for it has not ceased with his life. Hence its appearance now. Both in the schools and in the laboratory his writings and influence survive him. The work cited is a University text-book; and a scholarship has been instituted in his name for the promotion of vivisectional research. 
Positive and Negative, in a word, Male and Female, both of which subsist in the Divine Nature in absolute plenitude and perfect equilibrium. Expressed in the Divine IdeaAdam Kadmon - the qualities masculine and feminine of existence are, in their union and co-operation, the life and salvation of the world; and in their division and antagonism, its death and destruction. One in the Absolute, but two in the Relative, this ideal-but not therefore the less real-Humanity resumes both in itself, and is king and queen of the universe, and as such is projected through every sphere of creation to the material and phenomenal, causing the outer, lower, and sensible world everywhere to be made in the image of the inner, upper, and spiritual : so that all that subsists in the latter belongs to us here below and is in our image; and the two regions together make one uniform existence which is a vast Man, being, like the individual man, in constitution fourfold and in operation dual.

19. This doctrine of Correspondence finds expression through Paul, first, when he declares that "the invisible things of God from the creation of the world are clearly seen, being understood by the things which are made"; and again, when-applying it in its dual relation to the sexes of humanity-he says, "Neither is the man without the woman, nor the woman without the man in the Lord." The purity of its doctrine in this respect constitutes a proof of the divinity of the Kabbala. For it shows that this famous compendium belongs to a period prior to that destruction by the priesthoods of the equilibrium of the sexes which constituted in one sense the "Fall." Calling the woman the house and wall of the man, without whose bounding and redeeming influence he would inevitably be dissipated and lost in the abyss, the Kabbala describes her 
as constituting the centripetal and aspirational element in humanity, having a natural affinity for the pure and noble, to which, with herself, she always seeks to raise man, and being therefore his guide and initiator in things spiritual. Thus recognising in the sexes of humanity respectively, the manifestation of the qualities masculine and feminine of the divine Nature, Its power and Its love, the Kabbala duly inculcates the worship of that true Lord God of Hosts, the knowledge of whom constitutes its possessors the "Israel of God." "Not every one who says Lord, Lord, is of this heavenly kingdom; but they only who do the will of the Father Who is in heaven," and who accordingly honour duly His "two Witnesses" on earth-the man and the woman-on every plane of man's fourfold nature. It is by reason of Christ's duality that humanity beholds in him its representative. And it is only in those who seek in this to be like him, that Christ can by any means be born.

20. Close as was the agreement between Paul and the Kabbala in respect-among other doctrines-of the dual nature of Deity, the agreement stopped short of the due issue of that doctrine. And it is mainly through Paul that the influence we have described as at once astral, rabbinical, and sacerdotal, found an entrance into the Church. For, judged by the received text, Paul, when it came to a matter of practical teaching, exchanged the spirit of the Kabbala for that of the Talmud, and transmitted-aggravated and reinforced-to Christianity, the traditional contempt of his race for woman. The Talmud appoints to every pious Jew, as a daily prayer, these words :- "Blessed art Thou, O Lord, that Thou hast not made me a Gentile, an idiot, or a woman"; and while enjoining the instruction of his sons in the Law, prohibits that of the daughters on the ground that women are accursed. This reprobaticin of one whole 
moiety of the divine nature, instead of finding condemnation from Paul as erroneous, was adopted by him as the basis of his instructions concerning the position of women in a Christian society. For, after rightly defining the doctrine of the equality of the sexes "in the Lord," we find him writing to the Corinthians in the following strain: "But I would have you know that the head of every man is Christ, and the head of the woman is the man. For a man indeed ought not to have his head veiled, forasmuch as he is the image and glory of God ; but the woman is the glory of the man. For the man is not of the woman; but the woman of the man; for neither was the man created for the woman, but the woman for the man; for this cause ought the woman to have a sign of authority on her head, because of the angels." "Let a woman learn in quietness with all subjection. But I permit not a woman to teach, nor to have dominion over a man, but to be in quietness." "Let the women keep silence in the churches; for it is not permitted unto them to speak, but let them be in subjection, as saith the Law. It is shameful for a woman to speak in the Church." "For Adam was first formed, then Eve ; and Adam was not beguiled; but the woman being beguiled, fell into transgression." To the same purport writes Peter, who, as he certainly did not derive the doctrine from his Master, had doubtless been overborne in respect of it by Paul. ${ }^{7}$ Thus enforced, the doctrine of the subjection of

7 In I Pet. iii. 6 it is said that "Sara obeyed Abraham, calling him lord" ; whereas, according to Genesis, Abraham rather obeyed Sarai, calling her lady; for the change made by him in her name-from Sarai to Sara-implies an accession of dignity. Thereby, from being "my lady," she became "the lady," and representative of the feminine element in Divinity. The Deity is represented moreover as impressing on Abraham this injunction:- "In all that Sara hath said unto thee, hearken unto her voice." The fault of Adam lay not-as might be inferred from the passage as it stands in Genesis-in "hearkening to the 
the woman became accepted as an integral part of the Christian system, constituting in it an element of inevitable self-destruction.

21. The utterance last cited from Paul gives the clue to the source and motive of his doctrine concerning woman. It is a perversion, due to the influences already specified, of the parable of the Fall. When speaking in the Spirit, Paul declares the man and the woman alike to be "in the Lord." Subsiding from this level, and speaking-as according to his own admission, he was not unwont to speak - "foolishly," or of his own lower reason, he contradicts this statement and affirms that the man alone is made in the image of God,-the divine Idea of Humanity comprising the male element only,-and implies that the woman is but a mere after-thought, contrived to meet an unexpected emergency, and made, therefore, in the image, not of God, but of the man. Thus substituting the Letter for the Spirit, and wholly losing sight of the latter, Paul degrades the mystic Scripture from its proper plane and universal signification, to a level historical merely and local. By making Adam and Eve no longer types of the substantial humanity in its two essential modes, the outer and inner personality, but an actual material couple, the first physical progenitors of the race, he accepts in all its gross, impossible crudity the fable of the apple and the snake, and declares that because the first woman was beguiled, therefore her daughters-not her sons-must through all time to come bear the penalty of silence and servitude!

22. That which Paul would have taught, had his vision been uniformly enlightened, is the truth that, so far from the

voice of his wife," but in doing so when she was under beguilement "of the devil "-a qualification for the suppression of which the motive is obvious. 
woman being an inferior part of humanity, it is not until she is, on all its planes, exalted, crowned, and glorified, that humanity, whether in the individual or in the race, can attain to Christhood, seeing that she, and not the "man," is the bruiser of the serpent's head, the last to be manifested, and therefore the first in dignity. For this reason it is that only by the restoration of the woman, on all planes of her manifestation, can the equilibrium of man's nature, destroyed at the "Fall," be re-established. As it is, the direct effect of the teaching of Paul in this, and in certain allied respects, - notably the doctrine of atonement by vicarious bloodshed, - has been to perpetuate the false balance introduced by the Fall, and therein to confirm the Curse, to remove which is the supreme mission of the Christ as the "seed of the woman." On this subject Jesus himself had spoken very explicitly, though only in writings labelled "Apocryphal" are the utterances recorded. Of these, one, given by Clement, declares plainly that the kingdom of God can come only "when Two shall be One, and the Man as the Woman." In the other,-recorded in the Egyptian gospel,-Jesus, speaking mystically, says: "The kingdom of Heaven shall come when you women shall have renounced the dress of your sex"; meaning, when the representatives of the soul, namely women, no longer submit to ordinances which cause or imply inferiority on the part either of themselves or of that which they represent ; but, with the soul, are restored to their proper place. But, apart from any specific utterances, the whole character and teaching of Jesus are at variance with the doctrine and usage which have prevailed. For that character and teaching were in complete accordance with the course already from the beginning marked out in the planisphere of the Zodiac, wherein the rising of the constellation Virgo is followed by Libra, 
the Balance,-emblem of the Divine Justice,-in token of the establishment of the Kingdom of Righteousness which should follow upon the rehabilitation of the "Woman." Paul, on the contrary, -in his astral and non-lucid moments,-enforces the curse which Jesus would have put away; appeals to the Law which at other times he repudiates and denounces; and forges its chains anew by thrusting them around the necks of those who-he himself says-should be "no more under the Law, but under Grace." 8

23. Thus does Paul, to whose writings chiefly the various doctrinal systems of Christianity owe their origin, divide the Churches, and diminish the Reason, by falling back on convention and tradition. Now the Reason is not the "intellect,"-this, as we have insisted, represents but a moiety of the mind. The Reason is the whole humanity, which comprises the intuition as well as the intellect, and is in God's Image, male and female. This supreme Reason it is which finds its full expression in the Logos or Lord. Wherefore, in denying her true place to the woman in his scheme of society, Paul denies to the Lord His due manifestation on earth, and exalts for worship some image other than the divine. It is because they recognise in the Reason the heir of all things, that the devil and his agents always make it their first concern to cast it out and slay it. "This is the Heir," - the Reason, the Logos, the Lord,"come, let us kill him, and the inheritance shall be ours," - say those ministers of Unreason, the materialistic ortho-

According to the Apocryphal Epistles, and to ecclesiastical tradition, Paul, nevertheless, directed his own female associate-Theckla-to preach in public, and suffered her even to wear male attire. Paul, however, following the Levitical Code (Lev. xxi. 13), draws a distinction between married women and virgins, saying he had no commandment about the latter. 
doxies of Church and World. And no sooner is the Reason suppressed and cast out, than madness, folly, and evil of every kind step in and, taking possession, bear rule, making the last state-be it of community or of individual-worse than the first. For then in place of Christ and the divine image, is anti-Christ and the "man of sin"; and the rule is that of falsehood, superstition, and all manner of unclean spirits, having neither knowledge, nor power, nor wisdom, nor aught that in any respect corresponds to God. Of the mutilation and defacement of the Divine Reason by the Church, under the impulsion of Paul, the present state of both Church and World is the inevitable sequel.

24. Besides Paul, there are two others associated with the doctrine of the Logos, of names so notable as to necessitate a reference to them. These are Plato, and Philo called Judæus. They also recognised the Lord as the Logos and Divine Reason of things. But they failed to recognise the Dualism of the Divine nature therein, and by their failure ministered to the confirmation, rather than to the reversal, of the Fall and the Curse. Between Philo and Paul the points of resemblance are many and striking, foremost among them being the depreciation of woman, and the advocacy of vicarious bloodshedding as a means of propitiating Deity. Philo, who in these respects is a thorough sacerdotalist, claims to have been initiated into spiritual mysteries directly by the spirit of Moses. This, it will be now understood, is a distinct and positive proof, were any wanting, of the astral character of much at least of Philo's inspiration. $\mathrm{He}$, too, like many in our day, was beguiled by a spirit of the astral, which, personating the great prophet so long dead, insisted, in the name of Moses, on the sacerdoral degradations of the teaching of Moses. Like Paul,-though never attaining his 
elevation,-Philo oscillated continually between the Talmud and the Kabbala, the astral and the celestial, mixing error and truth accordingly, and ignored altogether the contrary presentation given of the divine Sophia in the inspired "Book of Wisdom,"-a book of which some have nevertheless ascribed the authorship to Philo himself !

25. Plato, and no less Aristotle, discerned in a perfect humanity the end and aim of creation, and in the universe a prelude to and preparation for the perfect man. Recognising, however, the masculine element only of existence, Aristotle regarded every production of Nature other than a male of the human species, as a failure in the attempt to produce a man; and the woman as something maimed and imperfect, to be accounted for only on the hypothesis that Nature, though artist, is but blind. Similarly Platodespite the intuition whereby he was enabled to recognise Intellect and Emotion as the two wings indispensable for man's ascent to his proper altitude-was wholly insensible to the correspondence by virtue of which the latter finds in woman its highest expression. For the strain in which he treated of her was so bitter and contemptuous, as largely to minister to the making of his country-instead of the Eden which results where, and only where, the woman is honoured and unfallen-a veritable rival of the "cities of the Plain." In his view, only they who have previously disgraced themselves as men, become re-incarnated as animals and women. The Logos of Plato is, clearly, no prototype of the Logos of that Christianity which is based on the duality of the Divine Being, and requires of the Christ that he represent the whole humanity.

26. The Fathers of the Church-step-fathers, rather, were they to the true Christianity - for the most part vied 
with each other in their depreciation of woman; and, denouncing her with every vile epithet, held it a degradation for a saint to touch even his own aged mother with the hand in order to sustain her feeble steps. And the Church, falling under a domination exclusively sacerdotal, while doctrinally it exalted womanhood to a level beside, though not to its place in, the Godhead, practically substituted priestly exclusiveness for Christian comprehension. For it declared woman unworthy, through inherent impurity, even to set foot within the sanctuaries of its temples; suffered her to exercise her functions of wife and mother only under the spell of a triple exorcism; and denied her, when dead, burial in its more sacred precincts, even though she were an abbess of undoubted sanctity.

27. The Reformation altered, but did not better, the condition of woman. Socially, it rescued her from the priest to make her the chattel of the husband; and doctrinally, it expunged her altogether. Calvinism is, on all planes, a repudiation of the woman in favour of the man; inasmuch as it recognises only will and force, and rejects love and goodness, as essential qualities of Being, whether Divine or human. And Protestantism at large, both Unitarian and Trinitarian, finds in its definition of the Substance of existence, place only for the masculine element. Even the great bard of Nonconformism, John Milton,-though finding woman so indispensable to him as to have thrice wedded,-disfigured his verse and belied his inspiration as poet, by his bitter and incessant depreciation of her without whom poetry itself would have no existence. For poetry is the function of genius, and genius, which is the product of sympathy, is not of the man, but of the woman in the man; and she herself-as her typical name Venus 
implies-is the "Sweet Song of God." ${ }^{\circ}$ In the same spirit the chief instrument of the Reformation, Martin Luther, declared of the two sacred books which especially point to the woman as the agent of man's final redemption - the books of Esther and Revelation - that "so far as he esteemed them, it would be no loss if they were thrown into the river."

28. The influence in question is not confined to the sphere of Christianity. It dictated the form assumed by Islamism. Originating in impulses derived from the celestial, this religion fell beneath the sway of the astral so soon as its founder, making a rich marriage, lived luxuriously and occupied himself with worldly matters. Sacerdotalism failed, it is true, to find in Islamism its ordinary mode of expression. But the principle of the doctrine of vicarious sacrifice in propitiation of the Deity, showed itself in the recognition of bloodshed as a means of proselytism. And women were relegated to a position altogether inferior, being regarded as differing from men not merely in degree, but in kind. For they were denied the possession of a soul; and their place in the Hereafter was supplied by astral equivalents under the scarcely disguised name of Houris. The Koran itself is little else than an imitation of the Old Testament, conceived under astral suggestion. A yet more unmitigated form of what may be called Astralism is the religion known as Mormonism; the sacred books of which are, throughout, but astral travesties of Scripture ; its doctrine of "spiritual wives," and of the position of woman generally, being similarly derived. It

- Such also is the signification of Anael, the Hebrew name of the "Angel" of her planet. Venus is said by some to be originally Phe-nus, having for root $\phi \eta \mu$. For an example of the nature of the true mysteries of this divinity, see C.W.S., part ii. (1), pp. 266-269. 
thus constitutes an instance in point, of the unceasing endeavour of the spirits of the sub-human to establish a kingdom of their own, instead of that of the Lord and the Divine Idea of Humanity. The Moslem Sufis had all the truth.

\section{PART III.}

29. It will be well, before proceeding to our conclusion, to take note of the objections with which it is usually sought to discredit-under the name of Mysticism-the system in course of exposition. These objections are comprised under two heads, of which the terms, respectively, are Plagiarism and Enthusiasm. By the former it is meant that the professors of Mysticism, instead of being the actual recipients of the experiences they record of themselves, borrow them from some common-but equally delusive-source. And by the latter it is implied that, at the best, the experiences, and the doctrines based upon them, are due to morbid conditions of mind. This, in plain language, means that the opponents of Mysticism-unable either to emulate or to confute it-try to get rid of it by charging its professors with dishonesty or insanity. And so far from this line of treatment being exceptional or rare, it is persistent and constant throughout the whole range of the literature characteristic of the age, and this in every class from the lowest to the highest, and in every branch of intellectual activity. Instead of being submitted to examination even the most superficial, the entire system comprised under the term Mysticism-its witnesses, its facts, and its doctrines-has in that literature been rejected off-hand and without inquiry, by the simple process of abrupt contradiction, and the ascription, in no measured degree, to its representatives and exponents, of pretence, 
imposture, charlatanism, quackery, hallucination, and madness-an ascription preposterous in the extreme in view of the status, moral and intellectual, of the persons aspersed. For of these the character and eminence have been such as, of themselves, to entitle their statements to attention the most respectful; and the Order to which, one and all, they have belonged, comprises the world's finest intellects, profoundest scholars, maturest judgments, noblest dispositions, ripest characters, and greatest benefactors; and in short, as has already been said, all those sages, saints, seers, prophets, and Christs, through whose redeeming influence humanity has been raised out of the bottomless pit of its own lower nature, and preserved from the abyss of utter negation. Of these, and of numberless others, the testimony to the reality of mystical experiences and the truth of mystical doctrine, has been concurrent, continuous, positive, and maintained at the cost of liberty, reputation, property, family ties, social position, and every earthly good, even to life itself, and this over a period extending from before the beginning of history until now. So that it may with absolute confidence be maintained, that if the declarations of Mystics are to be set aside as insufficient to establish their claims, all human testimony whatever is worthless as a criterion of fact, and all human intelligence as a criterion of truth.

30. The charge of Plagiarism is soon disposed of. It is true that the correspondence upon which the charge is founded subsists. But it is also true that this correspondence is only that which necessarily subsists between the accounts given of identical phenomena by different witnesses. The world's Mystics have been as a band of earnest explorers who, one after another, and often in complete ignorance of the results attained by their predecessors, have ascended 
the same giant mountain-range, and, returning, have brought back to the dwellers in the valleys below-too feeble or indifferent to make the ascent for themselves-the same report of its character and products, and of the tracts discerned from its various aspects and altitudes, showing thereby a perfect coherence of faculty and testimony. Such is the agreement which has been made the pretext for a charge of plagiarism against Mystics, simply because the region visited and reported on by them is a spiritual and not a material one, and Materialists will not have it that any other than a material subsists. Precisely the agreement which in all other cases is made indispensable as a proof of trustworthiness, is in this case interpreted as a token of collusion.

31. To come to the somewhat more plausible charge of Enthusiasm. It is alleged that the Mystics have conceived their system, not in that calm, philosophical frame of mind which alone is favourable to the discovery of truth, but in a spirit of excitement and enthusiasm of which the inevitable product is hallucination. Now, this allegation is not only contrary to fact, it is intrinsically absurd, whether as applied to the phenomena or to the philosophy of Mysticism. For one who, through the unfoldment of his spiritual faculties, is enabled to enjoy open conditions with the spiritual world, the suggestion that his consequent experiences are the result of hallucination, constitutes an act of presumption every whit as gross as would be the like suggestion concerning the material world if made by a blind man to one possessed of eyesight. For, as already observed, such is the nature of the experiences in question, that if they are to be disregarded as insufficient to demonstrate the reality of the spiritual world, no ground remains whereon to believe in that of the material world. It is true that the Materialist 
cannot-as a rule-be made a partaker of the evidences in question. But neither can the blind man have ocular proof of the existence of the material world. For him there is no sun in the sky if he refuse to credit those who alone possess the faculty wherewith to behold it, and persist in regarding himself as a representative man.

32. The case for the Mystic's intellectual results is equally strong. Such are the coherency and completeness of the mystical system of thought, that by all schools whatever of thinkers it has ever, with one consent, been pronounced to be inexpugnable, and that alone which would, if provable, constitute an explanation, altogether satisfactory, of the phenomena of existence. In this system, where apprehended in its proper integrity, Reason has in vain sought to detect a flaw; and they who have rejected it, have done so solely through their own inability to obtain that sensible evidence of the reality of the spiritual world, the power to receive and interpret which, constitutes the Mystic.

33. Nevertheless, of the fact of the Mystic's enthusiasm there is no question. But enthusiasm is neither his instrument of observation nor that of inference. And he is not more fairly chargeable with conceiving his system by the exercise of an imagination stimulated by enthusiasm, than is the believer in the world exclusively material. For, like the latter, he has sensible evidence of the facts whereon he builds; and he observes all possible deliberation and circumspection in his deductions therefrom. The only difference between them in this relation, is that the senses principally appealed to by his facts, are those, not of the man physical, but of the man spiritual, or soul, which, as consisting of substance, is necessarily alone competent for the appreciation of the phenomena of substance. Constituted as is man, while in the body, of both Matter and 
Spirit, he is a complete being-and therefore fully manonly when he has developed the faculties requisite for the discernment of both elements of his nature.

34. In the promotion of this development enthusiasm is a prime factor. By means of it the man is elevated to that region, interior and superior, where alone serenity prevails and perception is unobstructed, where are the beginnings of the clues of all objects of his search, and where his faculties are at their best, inasmuch as it is their native place, and they are there exempt from the limitations of the material organism. Attaining thus to his full altitude, he no longer has need to reason and compare. For he sees and knows, and his mind is content. For him, in the divine order of his spiritual system, "the woman is carried to the throne of God." The Zeus and Hera of his own celestial kingdom are wedded. The Adam, perfected, has found an infallible Eve. Existence is a garden of delights, whereof the fruits are the "golden apples" of knowledge and goodness. For the intellect and intuition-divine man and woman of his perfected humanity - are at one in the blissful home of his parent Spirit, the Within or fourth dimension of space, whence all things have their procession, and where alone, therefore, they can be comprehended. As well refuse credit to the researches of the meteorologist on account of the upward impulses of the vehicle on which he gains the loftier strata of air, or of the superior purity of the medium in which he operates, as to those of the Mystic on account of the enthusiasm by means of which his ascent is accomplished. For enthusiasm is simply his impelling force, without which he could never have quitted the outer, nether and apparent, and gained the inner, upper and real. Wherefore, even when the abstraction from the outer world attains the intensity of Ecstasy, there is nought 
in the condition to invalidate the perceptions, sensible or mental, of the seer. But simply are his faculties heightened and perfected through the exclusion of all limiting or disturbing influences, and the consequent release of the consciousness from material trammel and bias. There is, as already said, no really "invisible world." That which ecstasy does, is to open the vision to a world imperceptible to the exterior senses-that world of substance which, lying behind phenomenon, necessarily requires for its cognition faculties which are not of the phenomenal but of the substantial man. Says one eminent Manualist concerning the Neoplatonic Mystics:- "Their teaching was a desperate over-leaping and destruction of all philosophy." 10 Says another:- "In the desperate spring made at Alexandria, reason was given up for ecstasy." 11 Whereas the truth is, that the only sense in which reason can be said to be given up by the Mystic, is that in which, not reason but reasoning is given up, when, after exhausting conjecture blindfold, a man opens his eyes and sees, and so requires no further ratiocination. For ecstasy does but verify by actual vision the highest results of reason; though it may, and frequently does, thus operate in advance of the stage in his reasoning reached at the time by the seer. And so far, moreover, from superseding the necessity for the exercise of reason, it is impossible, without previous mental culture, duly to appreciate the results of ecstatic, any more than of ordinary vision. For all understanding is of the mind; and neither the vision of things terrestrial nor that of things celestial can dispense with the exercise of this. Of course, with the advent of knowledge the necessity for reasoning ceases, and in this sense it is true that the Mystic "destroys philosophy

10 Schwegler, Manual of Philosophy.

$"$ G. H. Lewes, Biog. Hist. Phil. 
by merging it in religion." But in this sense only. For, in his hands, philosophy simply, and under compulsion of reason, acknowledges religion as its legitimate and inevitable terminus, when not, through a limitation of reason, arbitrarily withheld therefrom. And, in a world proceeding from God, no reason would be sound, no philosophy complete, of which the conclusion-as well as the beginning-was not religion. So far, also, from such religious philosophy involving, as constantly charged against it, the abnegation of self-consciousness; it involves and implies the due self-completion of the consciousness by the recognition of its true source and nature. Thus, so far from "losing," the Mystic finds, himself thereby; for he finds God, the true and only Self of all. And if there be any who, recognising in these pages aught of goodness, truth, or beauty transcending the ordinary, inquire the source thereof, the reply is, that the source is no other than that just described, namely, the Spirit operating under conditions which a materialistic science, bent on the suppression of man's spiritual nature and the eradication of man's religious instinct, designates " morbid," and certifies as qualifying the subject for seclusion on the ground of insanity. ${ }^{12}$

35. We will endeavour by a brief examination of the standpoints of the two parties respectively, to exhibit the genesis and nature of the Mystic's enthusiasm. The Ma-

${ }^{12}$ In The Nineteenth Century for 1879 , Dr. Maudsley declares his readiness to have certified the lunacy of various of the most eminent saints, seers, and prophets. And the medical profession generally-following the lead of France-treats the claim to be in open conditions with the spiritual world as proof positive of insanity. Said a member of this profession on a recent occasion, in support of such action on the part of his brethren:- "If we admit Spirits, we must admit Spiritualism, and what then becomes of the teachings of Materialism?" Thus, in an age which vaunts itself an age pre-eminently of free thought and experimental philosophy, are the expression of thought and confession of experience made in the highest degree perilous when they conflict with the tenets of the prevailing school. 
terialist-who regards Matter as the sole constituent of existence, and himself as derived from that which, for its defect in respect of consciousness, he deems mean and contemptible-has for the supposed source and substance of his being, neither respect nor affection. No more than any one else can he love or honour the merely chemical or mechanical. Hence, like those who, springing from a low origin, have gained for themselves distinction, the last thing he covets is a return to that from which he came. How it arises that, being wholly of Matter, he has in him any impulse or faculty whereby to transcend even in desire his original level; whence come the qualities and properties, moral and intellectual, subsisting in humanity, but of which the most exhaustive analysis of Matter reveals no trace; whence the tendency of evolution in the direction of beauty, use, and goodness; whence evolution itself;-these are problems which are insoluble on his hypothesis, and which - since he rejects the solution proffered by the Mysticmust for ever remain unsolved by him.

36. The Mystic, on the other hand, discerning through the intuition the spiritual nature of the substance of existence, recognises himself, not as superior to that from which he has sprung, but as a limitation and individuation of that which itself is unlimited and universal, even the absolutely pure and perfect Spirit which is no other than God. Knowing himself to be thence derived and sustained, and only temporarily, and for a purpose conceived in infinite love and executed in infinite wisdom, subjected to inferior conditions, he yearns towards the whole of which he is a part, as a child towards its necessary parent, and strives, by divesting himself of the withholding influences of Matter, to rise into nearer resemblance to and contact with his divine Original. 
37. The materialist, on the contrary, regarding Matter as all, and its limitations as inherent in Being, sees in the endeavour to transcend those limitations but a suicidal attempt to escape from all Being. He strives, therefore, to attach himself yet more closely to Matter, little as he esteems it, and is content when he has succeeded in making from among things merely material, such selection as best ministers to his bodily satisfaction. And he cannot comprehend one of sound mind seeking more.

38. But such mistake of the phenomenal for the substantial, of the apparent for the real, cannot be made by one who to the sensations of the body adds the perceptions and recollections of the soul. Such a one knows by a divine and infallible instinct, which every succeeding experience serves but to confirm, that a perfection and satisfaction far transcending aught that Materialist can imagine, or Matter realise, are in very truth possible to humanity. And therefore the enthusiasm which inspires him is the enthusiasm, not of an earthly humanity, immature, rudimentary, and scarcely even suggestive of its own potentialities; not of a humanity which is exterior, transient, of form only and appearance; but of a humanity mature, developed, permanent, and capable of realising its own best promise and highest aspirations; a humanity interior, substantial, and of the Spirit; a humanity, though human, divine, in that it is worthy of its progenitor God, and at its best is God. The Materialist knows not perfection, nor reality, nor Spirit, nor God; and, knowing none of these, he knows not enthusiasm. Now, not to know enthusiasm, is not to know love. And he who knows not love, is not yet man. For he has yet to develop in him that which alone completes and makes the man, namely, the woman. Herein, then, is the full solution of the mystery of the Mystic's enthusiasm, and of the 
Materialist's inability to comprehend it. The one is already man, and, knowing what Being is, loves. The other is not yet man, and, incapable of love, has all to learn.

39. Not always did Materialists contemn enthusiasm and repudiate its products. Of one, at least, history tells who with enthusiasm sang of enthusiasm as the energising force of genius. It was no other than such a flight as that of the rapt Mystic in his ecstasy, which Lucretius ascribed to the inspired Epicurus, when he celebrated his vivida vis animi; for it was in virtue of his enthusiasm for a perfection transcending the animal, that Epicurus was enabled to overcome the limitations of the bodily sense, to "surpass the flaming walls of the world" material, to "traverse in spirit the whole immensity" of existence, and-returning-" to bring back to men the knowledge of possible and impossible." It has been reserved for the present age to produce the Materialist of a humanity so stunted and meagre that he knows not the meaning or value of enthusiasm, and in his ignorance makes of it a scoff.

\section{PART IV.}

40. Accepting without limitation or reserve the dictum -already cited -that "nothing imperceptible is real," the Mystic applies it in respect of the most recondite of all subjects of thought, namely, Deity, and both modes-the mental and the sensible - of perception. In doing this, he claims the justification of his own personal experience. For not only can he think God, he can also see God; the mind with which he does the first being a mind purified from obscuration by Matter; and the eyes with which he does the last being those of a more or less regenerate self. Of the seers of all ages the supreme beatific experiencethat which has constituted for them the crowning confirma- 
tion of their doctrine concerning not only the being but the nature of Deity-has been the vision of God as the Lord. For those to whom this vision has been vouchsafed, hope the most sanguine is swallowed up in realisation the most complete; belief the most implicit is merged in sight the most vivid; and knowledge the most absolute is attained, that the "kingdom of heaven is" in very truth "within," and that the king thereof is-where alone a king should be -in the midst of his kingdom.

4I. And yet more than this. By the vision of God as the Lord, the seer knows also that of this celestial kingdom within, the King is also the Queen; that, in respect of form no less than of substance, man is created in God's "own image, male and female"; and that in ascending to and becoming "one with the Father," man ascends to and becomes one with the Mother. For in the form beheld in the vision of Adonai, both $\mathrm{HE}$ and SHE are manifested. Who, then, is Adonai? This is a question the reply to which involves the Mystery of the Trinity.

42. Manifestation-it has already been explained-is by generation. Now generation is not of one but of twain. And inasmuch as that which is generated partakes the nature of the generators, it also is dual. That, then, which in the current presentation of the doctrine of the Trinity is termed the Father and First Person in the Godhead, is really the Father-Mother. And that which is theologically said to be begotten of them and called the Second Person and Son, is also dual, being not "Son" merely, but prototype of both sexes, and called in token thereof Io, Jehovah, El Shaddai, Adonai,-names, each of which implies duality.

43. Having for Father the Spirit which is Life, and for Mother the "Great Deep" which is Substance, Adonai 
possesses the potency of both, and wields the dual powers of all things. And from the Godhead thus constituted proceeds, through Adonai, the uncreated creative Spirit, the informer and fashioner of all things. This Spirit it is Who, theologically, is called the Holy Ghost, and the Third Person, the aspect of God as the Mother having been ignored or suppressed by a priesthood desirous of preserving a purely masculine conception of the Godhead. By the above presentation both the Churches, Eastern and Western, are right in what they affirm respecting the procession of the Holy Ghost, and wrong in what they deny.

44. This, the necessary method of the divine evolution and procession, for both Macrocosm and Microcosm, is duly set forth in the very commencement of the book of Genesis ; being expressed in the words:-And the Spirit of God moved upon the face of the Waters: and God SAID, Let there be Light, and there was Light." For, whenever and wherever creation-or manifestation by generation-occurs, God the Father co-operates with God the Mother-as Force, moving in Substance-and produces the Utterance, Word, Logos, or Adonai-at once God and the Expression of God. And of this Logos the Holy Spirit, in turn, is the Expression or creative medium. For, as Adonai is the Word or Expression whereby is manifested God, so the Holy Spirit, or Primal Light,-Itself Sevenfold,-is the Radiance whereby is revealed and manifested the Lord. Now the manifestation of the Lord-which also is the manifestation of God-occurs through the working in Substance of the Elohim or Seven Spirits of God-enumerated in aur second discourse-from Whose number first of all the number seven derives its sanctity. They are the Powers under Whose immediate superintendence Creation, whether of great or small, occurs. And of Them is the whole of 
the Divine Substance pervaded,- - the Substance of all that is.

"These are the Divine Fires which burn before the Presence of God; which proceed from the Spirit, and are One with the Spirit.

"God is divided, yet not diminished; God is All, and God is One.

"For the Spirit of God is a Flame of Fire which the Word of God divideth into many; yet the Original Flame is not decreased, nor the Power thereof, nor the Brightness thereof, lessened.

"Thou mayest light many lamps from the flame of one; yet thou dost in nothing diminish that first flame.

"Now the Spirit of God is expressed by the Word of God, which is Adonai."

45. This then is the order of the Divine Procession. First the Unity, or "Darkness" of the "Invisible Light." Second, the Duality, the Spirit and the Deep, or Energy and Space. Thirdly, the Trinity, the Father, the Mother, and Their joint expression or "Word." Last, the Plurality, the Sevenfold Light and Elohim of God. Such is the "generation" of the Heavens or celestial region, both in the universal and in the individual. And within the experience of each individual lies the possibility of the verification thereof. For in due time, to each who seeks for it, "the Holy Spirit teaches all things and brings all things to remembrance."

46. The Logos, or Adonai, is then God's idea of God's Self, the Formulated, Personified Thought of the Divine Mind. And whereas God makes nothing save through this Idea, it is said of Adonai,-

"By Him all things are made, and without Him is not anything made which is made. 
"He is the true Light which lighteth every man that cometh into the world.

"He is in the world, and the world is made by Him, and the world knoweth Him not.

"But as many as receive Him, to them He giveth power to become Sons of God, even to them that believe on His Name.

"He is in the Beginning with God, and He is God. He is the Manifestor by Whom all things are discovered.

"And without Him is not anything made which is visible.

"God the nameless doth not reveal God: but Adonai revealeth God from the Beginning.

"Adonai dissolveth and resumeth; in His two hands are the dual powers of all things;

"Having the potency of both in Himself; and being Himself invisible, for He is the Cause, and not the Effect.

"He is the Manifestor; and not that which is manifest.

"That which is manifest is the Divine Substance.

"Every Monad thereof hath the potency of twain; as God is Truain in One.

"And every Monad which is manifest, is manifest by the evolution of its Trinitv.

"For thus only can it bear record of itself, and become cognisable as an Entity." 13

13 As man, made in the "image" of Adonai, is the expression of God, so is the expression or countenance of man the express image of God's nature, and bears in its features the impress of the celestial, showing him to be thence derived. Thus, in the human face, by the straight, central, protruding, and vertical line of the organ of respiration, is denoted Individuality, the divine Ego, the I AM, of the man. Though single exteriorly, and constituting one organ, in token of the Divine Unity, within it is dual, having a double function, and two nostrils in which resides the power of the Breath or Spirit, and which represent the Divine Duality. The duality finds its especial symboli. sation in the two spheres of the eyes, which-placed on a level with the summit of the nose-denote respectively Intelligence and Love, or 


\section{PART V.}

47. We come to that which, both in its nature and in its import, is the most stupendous fact of mystical experience, and the crowning experience of seers in all ages from the remotest antiquity to the present day. This is the Vision of Adonai, ${ }^{14}$ a vision which proves that not only subjectively but objectively, not only mentally and theoretically, but sensibly and actually, God, as the Lord, is present and cognisable in each individual, ever operating to build him up in the Divine Image, and succeeding so far--and only so far-as the individual, by making the Divine Will his own will, consents to co-operate with God.

48. In respect of this vision, it matters not whether the seer have previous experience or knowledge on the subject ; for the result is altogether irrespective of anticipation. It is possible to him when-having purified his system, mental and physical, from all deteriorative and obstructive elements-he thinks inwardly, desires intensely, and imagines centrally, resolved that nothing shall bar his ascent to his own highest and entrance to his own innermost.

Father and Mother, as the supreme elements of Being. Though exteriorly two, interiorly they are one, as vision is one. And of the harmonious co-operation of the two personalities represented by them, proceeds, as child, a third personality, which is their joint expression or "Word." Of this the Mouth is at once the organ and symbol, being in itself Dual, - when closed a line, when open a circle; and also twofold, being compounded of line and circle in the tongue and lips. And as the place of issue of the creative breath, it is below the other features, since creation, in coming from the Highest, is in its direction necessarily downwards. Thus, in the countenance of the "Image of God," is expressed the nature of God,-even the Holy Trinity. For "these three are one," being essential modes of the same Being.

${ }^{14}$ The account here given of this Vision was written solely from the joint experiences of Anna Kingsford and Edward Maitland (Story of A. K. and E. M., p. 68). 
Doing this, and abstracting himself from the outer world of the phenomenal, he enters first the astral, where, more or less clearly, according to the measure of his percipience, he discerns successively the various spheres of its fourfold zone, together with their denizens. In the process he seems to himself, while still individual, to have lost the limitations of the finite, and to have become expanded into the universal. For, while traversing the several successive concentric spheres of his own being, and mounting, as by the steps of a ladder, from one to another, he is as palpably traversing also those not of the solar system only, but of the whole universe of being; and that which ultimately he reaches, is, manifestly, the centre of each, the initial point of radiation of himself and of all things.

49. Meanwhile, under the impulsion of the mighty enthusiasm engendered in him of the Spirit, the component consciousnesses of his system become more and more completely polarised towards their Divine centre, and the animating, Divine Spirit of the man, from being diffused, latent, and formless, becomes concentred, manifest, and definite. For, bent on the highest, the astral does not long detain him; and soon he passes the Cherubim-the guardians from without of the celestial-and enters within the veil of the holy of holies. Here he finds himself amid a company innumerable of beings each manifestly divine; for they are the angels and archangels, principalities and powers, and all the hierarchy of the "Heavens." Pressing on, through these towards the centre, he next finds himself in presence of a light so intolerable in its lustre as well-nigh to beat him back from further quest. And of those who reach thus far, many adventure no farther, but, appalled, retire, well content, nevertheless, to have been privileged to ap- 
proach, and actually to behold, the "Great White Throne" of the Almighty.

50. Enshrined in this light is a Form radiant and glorious beyond all power of expression. For it is "made of the Substance of Light"; and the form is that of the "Only Begotten," the Logos, the Idea, the Manifestor of God, the Personal Reason of all existence, the Lord God of Hosts, the Lord Adonai. From the right hand upraised in attitude indicative of will and command, proceeds, as a stream of living force, the Holy Life and Substance whereby and whereof Creation consists. With the left hand, depressed and open as in attitude of recall, the stream is indrawn, and Creation is sustained and redeemed. Thus projecting and recalling, expanding and contracting, Adonai fulfils the functions expressed in the mystical formula Solve et Coagula. And in this, so also in constitution and form, Adonai is dual, comprising the two modes of humanity, and appearing to the beholder alternately masculine and feminine according as the function exercised is of the man or the woman, and is centrifugal or centripetal. And as, continuing to gaze, the beholder acquires clearer vision, he discovers that, of the images thus combined, while one is manifested the more fully exteriorly, the other appertains rather to the interior, and shines in a measure through its fellow, itself remaining meanwhile in close contiguity to the heart and spirit. And whereas of these forms the inner is the feminine, the beholder learns that of the two modes of humanity, womanhood is the nearer to God.

5I. Such is the "vision of Adonai." And by whatever name denoted, no other source, centre, sustenance, or true Self can mortal or immortal find, than God as the Lord Who is thus beheld; and no other can he who has once beheld it-however dimly or afar off-desire. For, finding 
Adonai, the soul is content: the summit and centre of Being is reached; all ideals of Truth, Goodness, Beauty, and Power are realised; there is no Beyond to which to aspire. For All is in Adonai; since in Adonai dwells the infinite sea of Power and Wisdom which is God. And all of God which can be revealed, all that the soul can grasp, be her powers expanded as they may, is revealed in Adonai.

52. Of the term Adonai, as already stated, the Hindu equivalent, "Ardha-Nari," is represented as androgynous in form. But the personality denoted is that of Brahm, or pure Being, become Brahma, the Lord. And of the Hindû "Trimurti," the right hand, which typifies the creative energy, is Vishnu; the left, which represents the power of dissolution and return, is Siva, Adonai Himself being Brahma. The conditions on which this vision is vouchsafed are thus set forth for the benefit of his "beloved disciple," Arjun, by the "holy one," Krishna :- " Thou hast beheld this My wondrous form, so difficult of apprehension, which even angels may in vain desire to see. But I am not to be seen as thou hast seen Me, by means of mortifications, of sacrifices, of gifts, of alms. I am to be seen and truly known, and to be obtained by means of that worship which is offered to Me alone. He whose works are done for $\mathrm{Me}$ alone, who serves Me only, who cares naught for consequences, and who dwelleth among men without hatred, -he alone cometh unto Me."

\section{PART VI.}

53. This discourse and series of discourses will fitly close with an exposition of the relations subsisting between the Adonai, the Christ, and the Man. 
As Adonai the Lord is the manifestation of God in Substance, so Christ is the manifestation of the Lord in Humanity. The former occurs by Generation; the latter by Regeneration. The former is from within, outwards; the latter is from below, upwards. Man, ascending by evolution from the material and lowermost stratum of existence, finds his highest development in the Christ. This is the point where the human stream, as it flows upwards into God, culminates. Reaching this point by regeneration, man is at once Son of Man and of God, and is perfect, receiving in consequence the baptism of the Logos or Word, Adonai. Being now "virgin" in respect of matter, and quickened by the "one life," that of the Spirit, man becomes like unto God, in that he has the "Gift of God," or Eternal Life through the power of self-perpetuation. 'The Logos is celestial ; the man, terrestrial. Christ is their point of junction, without whom they could not touch each other. Attaining to this point by means of that inward purification which is the secret and method of the Christs, the man receives his suffusion by, or "anointing" of, the Spirit, and forthwith has, and is, "Christ." Christhood is attained by the reception into man's own spirit of the Logos. This accomplished, the two natures, the Divine and the human, combine; the two streams, the ascending and the descending, meet; and the man knows and understands God. And this is said to occur through Christ, because for every man it occurs according to the same method, Christ being for all alike the only way. Having received the Logos, Who is Son of God, the man becomes also Son of God, as well as Son of Man,-this latter title being his in virtue of his representing a regeneration or new birth out of humanity. And the Son of God in him reveals to him the "Father," a term which includes the "Mother." Knowing these, he knows the Life and 
Substance whereof he is constituted,-knows, therefore, his own nature and potentialities. Thus made "one with the Father," through the Son, the man "in Christ" can say truly, "I and the Father are one." This is the import of the confession of Stephen. " Behold," he cried in this ecstasy, "I see the heavens open, and the Son of Man standing on the right hand of God." For at that supreme moment the Spirit revealed to him, in visible image, the union through Christ of the Human and the Divine. Attaining to this union, man becomes "Christ-Jesus"; "he dwells in God, and God in him"; he is "one with God and God with him." It is at this point-Christ - that God and the man finally lay hold of each other and are drawn together. 'Thenceforth they flow, as two rivers united, in one stream. The man is finally made in the image of God; and God, as the Lord, is eternally manifested in him, making him an individuated portion of Divinity itself. Being thereby rendered incapable of relapse into material conditions, he is called a "fixed God," - a state which, as says Hermes in the Divine Pymander, "is the most perfect glory of the soul."

54. Recognising thus divine truth as an eternal verity in perpetual process of realisation by the individual soul, and the words Now and Within as the keys to all sacred mysteries, the Elect translate the symbols of their faith into terms of the present, and recite accordingly their Credo in this wise :-

"I believe in one God, the Father and Mother Almighty; of Whose Substance are the generations of Heaven and of Earth ; and in Christ-Jesus the Son of God, our Lord; who is conceived of the Holy Ghost; born of the Virgin Mary ; suffereth under the rulers of this world; is crucified, dead, and buried; who descendeth into Hell; who riseth 
again from the dead; who ascendeth into Heaven, and sitteth at the right hand of God; by whose law the quick and the dead are judged. I believe in the Seven Spirits of God; the Kingdom of Heaven; the communion of the Elect; the passing-through of Souls; the redemption of the Body; the Life everlasting; and the Amen." 
APPENDICES. 



\section{APPENDIX I. \\ THE CONSTITUTION OF EXISTENCE: ITS NATURE \\ AND UNITY. ${ }^{1}$}

PART I.

I. THE argument to the exposition of which this discourse will be devoted, is based on the doctrine of the Correspondence subsisting between things manifest to the inner sense and things manifest to the outer sense : "the invisible things of God being," as Paul says, "understood by the things that are made."

Now the reasonableness and necessity of this doctrine of Correspondence between the outer and the inner, between the real and the material, become apparent when we consider the essential unity of both,-unity, that is, of Substance, implying unity of origin and of mode.

1 This lecture is a reprint of Lecture V. of the First Edition of The Perfect Way. It was written by Anna Kingsford, and was delivered by her on Monday the 2oth June, 1881. Dr. Ernst Gryzanowsky of Leghorn, who "was recognised far and wide as one of the world's elcct, alike for his mental power, scientific and philosophic culture, and grasp of spiritual things," considered it, and particularly the third part of it, to be one of the most important and interesting chapters of The Perfect Way (Life of .A. K., vol. ii., p. r15). It was withdrawn from the Second and Third Editions in favour of Lecture V. of those Editions. Edward Maitland said: "The chicf reason for its withdrawal was our conviction of the superior importance of the subject of the latter and the impossibility of including both owing to the book being stereotyped. A secondary reason was Mary's reluctance to retain an illustration such as that of the 'Wandering Cell,' while physiologists were still undecided about the reality of the phenomenon " (Life of $A$. $K$., vol, ii., pp. 33, 115; and see Pref.).

It is now nearly thirty years since this lecture was given, and, though the reality of the phenomenon of the "wandering " cell, as therein described, does not appear to be expressly acknowledged by physiologists, it remains uncontradicted. Modern Science, so far as it has declared itself, appears to favour, rather than otherwise, the possibility of such a phenomenon. The idea of the watsdering cell has fascinated many modern 
2. As has already been advanced, the Real is substance in its condition of spirit or Mind; and the Phenomenal is substance in its condition of densification,-become manifest, that is, by Motion. Between these two,- - real and phenomenal, spirit and matter,-there is no arbitrary, definite line of separation, no bound of division precluding interaction, but a transitional difference only, such as exists at their extreme limits between all departments of nature. That which commonly is known as "Nature" comprises the phenomena cognisable by the outer sense; that which is commonly designated "supernatural" comprises all the inner kingdom, the primary kingdom of ideas, cognisable by the interior sense. This latter region, far from being "contrary" to the natural, necessarily precedes and controls the expression of nature, the phenomena of which exist only, because the super or ante-natural subsists. Hence the relation

minds, and each one works it out in his own way. Dr. Halliburton, for example, in his well-known Handbook of Physiology (7th edition), after pointing out that the most obvious physiological characteristic of most cells is their power of movement (p. I2), speaks of "a gliding movement" which has been noticed in certain animal cells; " the mobile part of the cell is composed of protoplasm, bounding a central and more compact mass ; by means of the free movement of this layer, the cell may be observed to move along" (p. 13) : Max Verworn, in his General Physiology (1895), referring to "amœboid wandering cells of various kinds," says that amœboid novement " is found wherever there exist naked protoplasmic masses, that is, cells, the protoplasmic bodies of which are not surrounded by cell-membrane" (p. 234): Metchnikoff, in expounding his great theory of the work of the phagocytes, says that " distributed throughout every part of our bodies are certain cells which fulfil special functions of their own. They are capable of independent movement, and also of devouring all sorts of solid matter, a capacity which has gained them the name of phagocytes or voracious cells" (The Nature of Man (1904), p. 239): and Dr. A. T. Shofield, writing of the cell in a recent article on the Systems and Organs of the Body, says that the cell " is capable of spontaneous motion, and frequently of locomotion," and he refers in particular to the colourless corpuscles which, he says, "seem able to make their way actively and at will about any part of the body," for "their movements appear to be guided by some sort of instinct, and are by no means haphazard " (Harmsworth Self-Educator (1906), vol. i., pp. 199-200).

I have been assured by those who are in a position to know, that though, since 1881 , knowledge on this subject has increased and theories have differed and differ, there is nothing in modern science that can be said to be inconsistent with the facts about the cell upon which Anna Kingsford based this Lecture. One thing is certain, and that is, the doctrine contained in this Lecture is spiritually and substantially true, and this ought not any longer to be kept in the background or allowed to be forgotten through the withholding of this Lecture from publication.-S. H. H. 
of Mind, - which is Substance under the attribute of thought,- - to Matter,- which is Substance under the attribute of extension ; and hence also the possibility of the power, wrongly called " miraculous," which is the prerogative of men who develop and exercise all their human faculties. Such are men understanding the procession of nature, and acting by and within laws the conditions for enforcing which are not fulfilled by the majority of the race. For, as all Substance is single, so all Force is single ; and Law is the mode of application of Force, and of its relation to Substance. Law, therefore, though it seem to be diverse, is one in principle; and this principle is expressed pretty closely by the term Polarisation,-analogous to Gravitation. So long as we work within and by the Law, we direct Force and maintain Order and Life : when we violate it, Force recoils upon us, and disorder and death ensue in the economy concerned. These three entities, - Force, Substance, and Law,-are present throughout the universe, whether in the real or in the phenomenal world, because between these worlds there is no difference of essence, but only of extension or mode. That is to say, the attributes of Matter are dependent for their manifestation on Condition ; this condition itself being due to the operation of Force upon the substance of Matter. Substance is spiritual, fluid or solid according to its dynamic state; and Force, however immeasurably active or restrained, is eternally present, and the Law of its manifestation is, in every degree of that manifestation, the same. Force, whether active or latent, is co-equal with Substance. We can conceive neither of Substance without Force, nor of Force without Substance, and both are expressed in and by Law. From these three, co-equal and co-eternal, proceeds the universe.

3. As in a lake are mirrored the images of things above it, so, in the Phenomenal are seen the projections of the Real. By means of the former we apprehend the latter; for the process of the rays which convey the image from the invisible rarer medium of the airy atmosphere to the tangible grosser medium of the watery, is identical and continuous in both.

4. Such is the basis of the famous doctrine of Correspondence, to which the name of Swedenborg has become attached, but which is equally Spinozic, and, thousands of years before Spinoza, belonged to the Hermetic and Kabbalistic philosophy ; the doctrine, in short, upon which all parabolic or mystic scriptures are based, and in the principle of which is contained the Key of their interpretation. The etymology of the word Religion 
itself finds an explanation in this doctrine, which binds together (religare) the things of heaven and the things of earth, whether in the Macrocosm or in the Microcosm. As the will of the religious man is bound up with the Divine Will, so is the law of things earthly with the law of things heavenly. And, as we have seen, this doctrine is formulated on the Hermetic (and Spinozic) proposition of the unity of the substance of all things. Great and small, outer and inner, nether and upper, phenomenal and spiritual, microscopic and telescopic, all are of one essence, manifested by one force, and governed by one law. To paraphrase the well-known aphorism of Islam : "There is but one Substanie, and the Law of Correspondence is its Exponent."

5. In accordance with these premises, we propose in this lecture to examine the constitution, mode, and behaviour of the ultimate organised element cognisable to the outer sense, as a representative type, or parable, in all three particulars, of the microcosmic and macrocosmic systems, cognisable to the outer sense in part only. This ultimate element of organised matter is called the Cell. Microscopic in its proportions, and, generally speaking, wholly invisible to the unaided eye, it is identical in both the vegetable and animal economies; and is known to botanists and anatomists as the entity which constitutes the organic unity, the primative representative of Life individualised. It is by studying side by side the constitution and history of this radical organism, and those of the Man and the Planet, as we find them set forth in Hermetic philosophy, that we propose to show the analogy subsisting between the ultimates at each extreme of the ladder of organic existence, and thus from the Sensible to rise to the apprehension of the Rational.

6. To the objection that, in instituting the comparison about to be made, we are arguing from that which is wholly phenomenal to that which is phenomenal in part only, the answer is, that the objector has not yet grasped the fact that there is nothing wholly phenomenal in the universe. The immaterial is but substance in a more ethereal and essential condition than the material, since the method and constitution of all things are necessarily one. As the substantial is that which sub-stands the phenomenal, phenomenal form and action are what they are because they represent to phenomenal sensation the processes of eternal positive Being. That which causes the Soul and the astral body to evade cognition by the outer perception, is not a difference of kind from the phenomenal, but a difference of mode ; the mode of their manifestation being ordinarily such as 
to render them inappreciable by the methods employed for the cognition of objects commonly called Sensible.

7. To give an illustration: The radiation which composes the solar spectrum possesses a dimension much larger than that of which the eye can take cognisance. This spectrum is, in reality, composed of three distinct parts :-Ist, of luminous rays, which, acting on the retina of the eye, constitute the spectrum of seven simple colours; 2nd, of rays lying within the red ray, and which do not affect the vision, but the existence of which is scientifically demonstrated by their calorific power; 3 rd, of rays lying beyond the violet, equally invisible, but whose existence is not the less demonstrable by chemical tests. Thus the spectrum consists of three sorts of rays, calorific, luminous, and chemical ; the second of which only is directly appreciable by the organ of vision, the existence of the others being ascertained by experimental observation involving an exercise of mind.

8. Now, the reason why we cannot see the rays lying inside the red, is, that the optic nerve is so constituted as to be sensitive to the vibrations of the universal ethereal medium only when the number of them is contained within certain limits; for the ether it is, and not the air, which, by means of the vibrations of its molecules, causes in us the sensation of light. The red ray is found by scientists to set up in the ethereal medium a number of vibrations estimated at 496 millions of millions a second; and the violet ray, a number estimated at 728 millions of millions a second. These two colours, and all the other five lying between them, are perceptible to the eye ; but the constitution and disposition of the optic nerve does not permit the appreciation of colours producing a less number of vibrations than those set up by the red ray, or a greater number than those due to the violet. Nevertheless, the invisible rays certainly affect the ether in the same manner as do the visible rays; for it is ascertained that caloric is transmitted by the same vehicle as light, the difference between the two being expressed only by a difference in the degree of the velocity of motion respectively produced in the mass of ether. Similarly, the exceedingly refrangible rays beyond the violet determine chemical action only, because the intensely rapid and short undulations to which they give rise, manifest their action, not in heat, nor in light, but in the operation of composition, decomposition, and allied phenomena.

9. This study of the spectrum affords an analogy of the relation between the material and the spiritual. The spectral rays are all one in kind; they are all manifest by motion; and that 
motion is controlled by one law. But our vision is capable of responding only to the results of motion within certain limits. We accept the fact of the existence of the imperceptible rays, and recognise the method of their transmission as identical with that of the visible rays, although their mode of operation is so different from that of the latter that the relation between the two is demonstrable only by an application of science. In like manner the spiritual, or unmanifest, becomes cognisable by the mind, and is discerned as necessary to the explanation and completion of the phenomenal, by means of the phenomenal itself. The phenomenal is but a part manifestation of the whole ; it is that portion of the planisphere which, at any given moment, happens to be above our horizon.

IO. Since, thus, the Spiritual is in thought that which the Material is in extension, there is nothing illogical in reasoning from the one to the other. And we may fitly take the phenomenal as an expression adapted to our limited bodily apprehension, of substantial verities lying eternally within and beyond the range of our transient perceptive organs. Of these Verities, which constitute the kingdom of the Real, the phenomenal may be likened to the shadow, which, though readily apprehended by the mere exterior sense, appeals for comprehension of its nature and import to the extension of sensation in reason. Thus Mind is competent to grasp the universe which, transcending sense, occupies both the Within and the Beyond.

II. Now the universe of the phenomenal is resumed and epitomised in the organic Cell. By this term is denoted a mass of organised living matter, having a determinate form and constituting an individuality capable of nourishing and reproducing itself. Primitively spherical, but able to assume various forms, this organic unity may, according to circumstances, be reduced to a homogeneous mass of albuminoid substance, or, in a more developed and perfect state, it may offer distinct parts having different characters and properties; all these parts being modifications, by differentiation of polarity, of the same fluidic substance. This fundamental substance is known as Protoplasm, itself highly complex in constitution, containing chiefly the four elements,-oxygen, hydrogen, carbon, and nitrogen,-sulphur and phosphorus, and distinguished from all other modes of matter by the fact that it possesses vital qualities, absorbing, appropriating, reproducing, and dying.

12. The Cell, thus constituted, is the basis of every living economy. Of such microscopic entities, themselves individual 
and vitalised, are composed the solids and fluids of all organic bodies, whether animal or vegetable. The cuticle, the muscular tissue, the nervous tissue, the cartilaginous and bony fabrics, the connective tissues, the blood and the lymph of the human economy, all are built up and constituted of cellular entities, varying, according to the particular tissue or humour, in aspect, dimension, constitution, and consistence.

13. A cell, in its completest expression, consists, from without inwards, of cell-membrane, protoplasmic contents, nucleus, and nucleolus (fig. 3). In some cases, as in the blood and lymph corpuscles, the exterior limits of the cell are formed by the fluid proto. plasm ; but generally, as in the fat-cell, the nervecell, and most others not suspended in a liquid medium, the protoplasm is bounded and imprisoned by a distinct sheathing called the cell-wall or membrane. On the subject of this membrane innumerable discussions have arisen among histologists, some maintaining it to be an independent isolable envelope, possess-

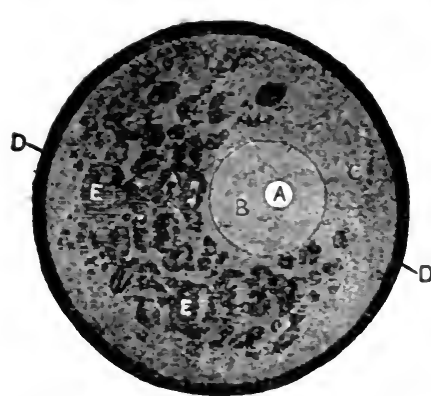

Fis. 3.-Section of the Typical Organic Cell.

A, Nucleolus: Divine Spirit, Nous, Jechidah. B, Nucleus: Soul, Anima Divina, Neschamah. C, Protoplasm or Cell-substance: Perisoul, divisible into two parts, i.e., Earthly Mind, Anima Bruta. Ruach; and Astral body, Shade, Nephesch. D, Cell-membrane: Physical body. E, Protoplasmic Granules: Astral Reflects or "Spirits." ing special chemical qualities, and separable from the cell either by mechanical expression, or, as in the fat-cell, by dissolving out the contents by the aid of chemical agents-alcohol or ether; others affirming it to consist only of a hardening or coagulation by concentration, more or less pronounced, of the external surface of the protoplasmic substance, constituting thus a periphery identical in nature with the protoplasm itself. This latter view is now generally accepted. Formerly, too, it was deemed impossible for a cell to exist without a capsular membrane; now it is known that this envelope is often missing, and that its physiological value is relative merely. 
14. The composition of the protoplasm, or fluidic content of the cell, undergoes variations according to the age of the cell. At first it is formed only of albuminoid substance ; but later, the processes of assimilation and of disassimilation which occur in and by it, give rise,-either by intussusception, or by internal generation, - to the production in its mass of diverse granulations, pigmentary, fatty, and other. The proportion borne by the protoplasmic contents of a cell to its other constituent parts varies with the kind of cell, and with its age and circumstances. Under certain conditions, this plasmic medium may,-as in old epithelial cells on the extreme surface of the skin,-become by degrees wholly solidified, incapable of exercising its normal functions, and transformed into a fixed horny mass known to anatomists as "keratine." This mass is formed by the intimate merging of the nucleus, cell-membrane, and transformed fluidic body, all of which have become indistinguishable and inseparable one from another, the hardening mass of the degraded protoplasm having gradually absorbed alike the nucleus and the periphery. Such cells are no longer capable of self-perpetuation; they gradually detach themselves, and are shed from the economy of which they were once living elements.

15. The nucleus of the cell may be examined microscopically with most distinctness in embryonic tissues. It presents the appearance of a sphere or vesicule, the contents of which are more or less liquid, homogeneous, and transparent. This substance differs in quality from that of the protoplasmic fluid surrounding it, with which it is prevented from fusing by a capsule so tenuous and diaphanous that its presence, even under the strongest lens power, is demonstrated chiefly by the current observable in its contents. In the interior of the transparent matrix of the nucleus is discernible, in the perfect cell, a tiny, brilliant globule called the nucleolus. This bright central point,of spherical form and albuminoid nature,-was formerly regarded as pre-existing the nucleus, and determining its production. It is now ascertained to be an ulterior formation, resulting from a differentiation in the liquid mass of the nucleus. In some cells the nucleolus is represented, not by a single brilliant point, but by two or even more, all identical in origin and nature, and manifold only in the same sense as light itself.

16. Such, briefly, is the constitution of the organic vital particle. Before inquiring into its behaviour, it will be well to compare the details of structure just described with those of the human kingdom, as they are presented to us by the Gnosis alike 
of all ancient schools, the Hermetic, the Buddhistic, the Platonic, and the rest.

According to this Gnosis, Man attains his completion and is made in the Divine image on becoming fourfold. He is constituted, from without inwards, of body, astral or fluid body, soul, and spirit. So also, we have seen, is the perfect cell. Its cortical envelope, or wall, represents its fixed body ; the protoplasmic medium lying within represents its fluid body; the nucleus, its soul; the nucleolus, its spirit. And just as all these different elements of the cell are produced from one material substance by variation of polarisation, so are all the four elements of Man begotten in the bosom of one Substance, and that the one Vital Living Mother, the essential Protoplasm of both Microcosm and Macrocosm. And as the material protoplasm is thus quadruple in potentiality, so is also the Divine Protoplasm quadruple, inasmuch as within it are contained the alchemic elements of the constitution of the fourfold universe, human and general. This Divine basis of life it is to which all lives are ultimately traceable.

17. As the cell-membrane is made and put forth by the fluidic cell-content, so precisely is the phenomenal human body made and put forth by the astral, or, as sometimes it is styled, the "fiery" body. And as the histologist may by mechanical compression expel the fluidic contents from a cell, leaving the empty sheathing on his object-glass, so the soul and astral body may be expelled from the phenomenal body. And, moreover, as in the early age of the cell, its fluidic medium is pure and clear, but gradually, from within or from without, becomes loaded with floating granulations, sometimes so numerous and so dense as to conceal the nucleus and to mask its very existence; so the astral element of man, - which in childhood is translucent and unclouded, - becomes, as he grows older, thronged with phantasmal images, evoked from within or reflected from without, which obscure the perceptions of the soul, and may even threaten to absorb or engulf it. It is for this reason that, in order to receive "the kingdom of Heaven," man must revert to the pure condition of childhood and be "born again," by which process he clears his astral element, and becoming "pure," "sees God,"-the Sun and Nucleolus of his Soul.

18. The plasmic medium of the cell may, as we have observed, become by degrees so solidified and horny as to be exclusively cortical, and to present throughout its whole mass a uniform hard consistency, neither nucleus nor protoplasm being any 
longer distinguishable. So also may man, by persistent tendency outwards, grow wholly materialised, his soul and his rational part degrading continually, and becoming at last altogether sensual, and capable of apprehending material things only. What is the end of such a man? We have seen what is the end of the cell under similar conditions. It pushes its way more and more to the surface of the cuticle, and at last disintegrates, being shed or pared off, and so is lost to the economy. In like manner, by the same law operating identically in small and great, is the finally unregenerate man lost. He has ceased to fulfil the conditions of being, and life can no longer retain him.

19. The nucleus of the cell answers, as we have seen, to the Soul. Within it is a tiny brilliant point, the nucleolus, the nature of which has never been determined, but which is known not to exist in all cells. Many cells go through their entire course of evolution from birth to death without ever possessing a nucleolus. Its correspondence in man is the Divine Spirit. The possession of this constitutes him man in the perfect sense. Like the nucleolus in the nucleus, it appears in the soul through a differentiation of polarity occurring in the psychic element itself. Rudimentary men and mere animals have it not at any stage of their existence as rudimentaries. And as, on the other hand, the nucleolus is seen in certain cells to be dual or even multiple, so also, in some high and saintly souls the EEon or "Double Portion" may be manifest, thus constituting them media for the Macrocosmic as well as the Microcosmic God. Or, -as with the Christs, - the Divine Spirit may rest upon them with such fulness as to polarise in them all Its Sevenfold powers. ${ }^{2}$

\section{PART II.}

20. We now pass to the second part of our study, namely, the history of the behaviour, or evolution, of the Cell. The nucleus was long ago demonstrated, - at least in the greater number of cases,- to exist prior to the formation of the cell itself as a complete entity, of which it has therefore been considered by many observers as the necessary point of departure. ${ }^{3}$ But it is only

2 Isaias xi. 2, 3 .

3 It appears to be well established that the nucleus exercises a controlling influence over the nutrition and subdivision of the cell; any portion of the cell cut off from the nucleus undergoes degenerate changes (Dr. Halliburton's Handbook of Physiology, seventh edition, p. ro). 
very recently that the entire history of the cell, from its earliest to its latest stages, has been consecutively traced and chronicled.

21. The Journal of the Royal Microscopical Society for June, 1879, contains a paper which had been previously read before the Society by two well-known students of histology, on the development and retrogression of the typical cell.

The authors of this careful study have assured themselves that all fixed or stationary cells have once been "wandering" cells, that is, nomadic embryonic entities moving over the free surfaces of membranes, in search of some medium or tissue for which they have a physiological affinity, and which, when met with, they will penetrate, by passing from the upper free surface of the membrane into the endothelium-covered tract wherein alone fixed cells are found. Here they will root themselves, and take on the character of "fixed" cells, becoming through contiguity, or some other cause, similar to the other fixed cells of the tissue into which they have been drawn. Young wandering cells, just entering on the migratory stage, consist of a nucleus surrounded by a mere film of protoplasm or cell-substance, but having no peripheral envelope (fig. 4). Older wanderers, ripe for a new stage of development as fixed cells, have abundance of protoplasm round their nucleus. Every gradation of form may be seen between these two extreme types; and, whenever a wandering cell is about to become a fixed cell, it develops a considerable amount of protoplasm, which increases in such a manner as to form by degrees the strong peripheral envelope characteristic of the condition of a fixed cell. Having fulfilled its period of evolution and existence in this form, it returns into its original state of a "wanderer." Of this return the process, - which has been observed,-is described as follows.

22. During the development of the cell,-taking for type a cell of adipose tissue, - it is noticed that as the protoplasmic element of the cell increases, the number of floating granulations contained in this element increases also, pari passu. In the absorption or retrogression of the cell, there are thus two elements to get rid of before the cell can return to its original condition, namely, excess of protoplasm and the corpuscular deposits it contains. During the evolution of the cell in its fixed state these granulations may become so numerous or extensive as to distend the matrix of the protoplasm, and displace the nucleus from its central position. Even in the process of return to the frec condition, the nucleus does not at once recover its former place and dimensions, but by degrees only, as the process about to be described admits. 
23. When a fixed cell is about to disintegrate, the granules which crowd the protoplasmic medium are seen becoming as it were detached from the transparent fluid containing them, and appear as if increasing in number. Suddenly, and without any

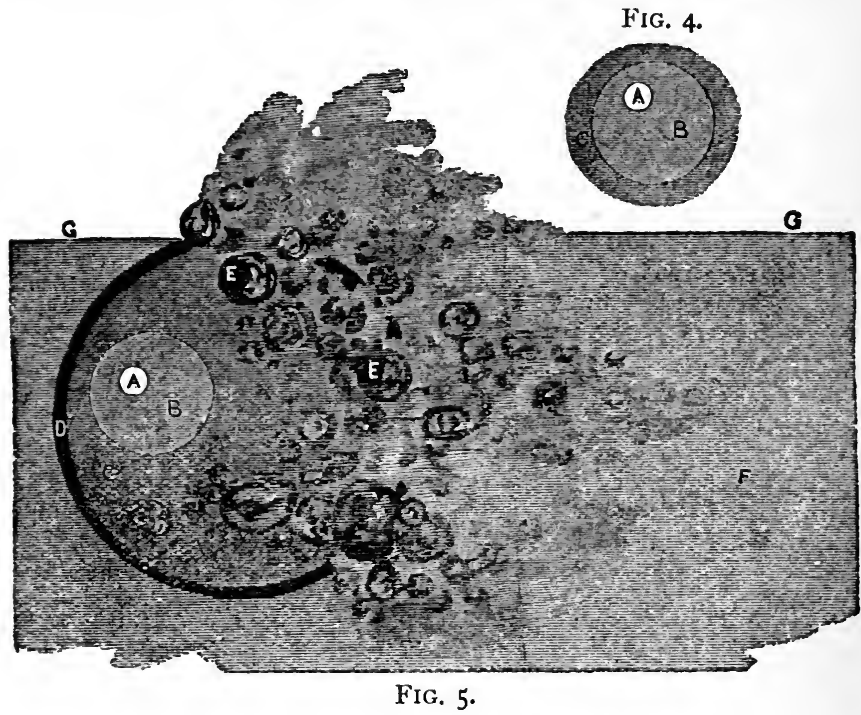

Fig. 4. - Wandering Cell, deprived of Cell-membrane and Granules (section).

A and B, same as in fig. 3. C, Thin Protoplasmic Zone ensheathing the Nucleus after the rupture of the Cell-membrane and dispersion of the Granules.

FIG. 5.-Break-up of the Fixed Cell, and Dispersion of the Granules and Excess of Protoplasm (section).

A, B, C, D, and E, same as in fig. 3. F, Parenchyma of the Tissue in which the Cell resides. G, Free Surface, or Endothelium of the Tissue, above which the Wandering Cells move.

particular change or warning, the cell begins to break up. The granules are shed on every side and apparently in no definite direction. With them goes also the excess of the protoplasm which contained them, and, of course, the external periphery 
formed by the thickening of the outer ring of the protoplasm. The nucleus is then again left in the condition of a "wanderer," with only a faintly tinted zone of protoplasm attached to it. Thus, when the period of life of the fixed cell is ended, its essential element, surrounded only by this transparent investment, regains the power of locomotion and drifts off from the scene of its quondam existence (figs. 4 and 5).

24. Its nomadic faculty being now restored, there is every reason to conclude that it may travel into quite other localities, and by contiguity become again a fixed entity in another kind of tissue. For as, when first observed, the nucleus and its filmy envelope constituted a wandering cell, having migrated along free surfaces from some part unknown to the observer; and as, when last observed, it had returned to that condition, the obvious inference is, that at the time of the first observation it may already have passed through other evolutions and disintegrations than that one process actually described, and that when last observed, it was on its way again to undergo a similar evolution, and so on, perhaps, almost indefinitely. The question is one, of course, involving great patience and accuracy on the part of the investigator, and great precision on the part of his instruments. The researches detailed in the paper just quoted, were carried on with unwearied care for a term of more than four years, ${ }^{4}$ and their results verified on a vast number of preparations. A sequel to these studies is promised, when the history of the progress and ultimate destiny of the cell shall have been still further successfully traced. Meantime, so far as concerns the facts ascertained, the behaviour of the elements constituting the cell parallels exactly the history of the constituent elements of man.

25. Let us take the first fact established,- that all fixed cells having cortical envelopes have once been wandering cells consisting only of nucleus and surrounding protoplasmic film,- and compare it with the Hermetic doctrine concerning the soul. The nucleus, as we have seen, represents the soul, and the protoplasmic fluid the astral region of the human kingdom. Like the soul, the nucleus pre-exists as a wandering entity, clothed only in the transparent intangible medium which constitutes the link between it and the earthly, and which indicates it as still "under the elements," and liable to the vicissitudes of "cxistence." The time for it to take on itself a new condition by redescending into Matter, is determined by the law of affinity, which is one

4 Without recourse to vivisertion. 
with that of gravitation. When this time arrives, the soul penetrates the earthly atmosphere, which is represented by the endothelium-covered tissue, and roots itself in the sphere of those incarnate personalities with which, at such time, it has the closest sympathy or magnetic affinity. It then, by means of its astral body, puts forth a phenomenal material periphery, or fleshly body, and becomes incarnate as animal or as man, its new condition not being determined arbitrarily, but being always the inevitable result of its acquired affinities, behaviour, and capacities. That which determines the incarnation of a soul, is its gravitation towards Matter, through being weighted, so to speak, with a dense astral element, incapable of present sublimation, and its need of further purgation in the earthly sphere before it can mount to the celestial. So, accordingly, we have seen, that which converts the wandering nucleus into a fixed cell, is precisely the great abundance of the protoplasmic element with which it is, at any given moment, surrounded. If man would escape the necessity of re-incarnation, he must destroy in himself the tendency towards Matter, the love of the flesh, and the affection for the objects of earth and of the outer sense ; for all these minister to the astral, and the astral to them, and inevitably cause gravitation towards the earthly sphere. And the soul is and must be obedient to this law of gravitation; for, as has been observed, it is the universal law in which, and by which, everywhere, Force works in Substance.

26. We have seen that when the time arrives for the fixed cell to disintegrate, it sheds the greater part of its protoplasmic element containing the granulations and corpuscular deposits which, during its evolution as a fixed cell, it had accumulated therein. Thus, too, at death, man sheds his body, and with it that part of his astral personality (anima bruta) which is intimately attached to it, and which contains those unsubstantial reflects and images of mundane things developed in his mind by the circumstances of the earth-life he is about to quit: mirages and illusions which Death breaks down; clouds and phantasms which, perhaps, may have so overspread the man's outer reason as to obscure his inner life and choke the free expansion of his soul and its divine germ. For in the normal and unperverted condition, the place of this divine germ in the man, like that of the sun in the system and of the nucleus in the cell, is central. Hence the common phrase used of the man in whom the love or soul element maintains its human ascendency: "His heart is in the right place." But when the astral or earthly mind develops 
unduly, and its false growths begin to obscure and repress the intuition, the man resembles the cell in which the nucleus is driven from its central position and replaced by the products of degeneration.

27. With regard to these products our authors further observe : "The point of greatest importance is the nature or character of the granules which we see leaving the cells and travelling through the gelatinous matrix of the membrane, apparently by virtue of their own power of locomotion. Indeed, the end of these studies only opens out to us the commencement of other more minute, more delicate, and more important researches. As may well be conceived, the first point of importance to settle was, whether they were fatty or protoplasmic in their nature. If, as was likely, they were fat-granules, little importance was to be attached to them ; but if, on the contrary, they were protoplasmic in character, they were all-important as a key to the past and an explanation of the future."

In order to decide this point, recourse was had to many and various chemical tests, the result of which unmistakably proved these granules to be, not fatty, but protoplasmic in nature. "The character stamped upon them by staining tests," continues the recital, "as well as the power they appeared to possess of moving off at pleasure from the parent-cells by their own inherent power, show us that we have here to do with something specific in biology, something vastly more minute, and a stage more elementary than the composite body called a cell; something which lives and moves and has its being independently of the cell, and to which we are called upon to assign a specific sphere in nature. Have we here, in these living atoms, germs, the micrococci, the zooglœa, the spores, fungi, bacteria, or the spores from which bacteria are developed? We have no doubt that they furnish a key to the alleged discoveries of some of the above-named classes of organisms in certain specific or infective diseases in the past, and may probably furnish an explanation of many infective processes in the future. Dr. Bastian, in lis work, On the Lower Organisms, says, in endeavouring to account for the presence of bacteria within the living body: "We must imagine that when the vital activity of any organism, whether simple or complex, is on the wane, its constituent particles (being still portions of living matter) are capable of individualising themselves, and of growing into the low organisms in question. Just as the life of one of the cells of a higher organism may continue for some time after the death of the organism itself, so, 
in accordance with this latter view, may one of the particles of such a cell be supposed to continue to live after even cell life is impossible.'

"This hypothesis of Dr. Bastian is exactly applicable to the granular particles we have described; we believe them to supply the missing link between cellular and germ pathology ; and their bearing on the causation of disease will become more apparent when, at another time and place, we have an opportunity of showing that granular exodus is not confined to healthy cells, but that in virulent disease we have the characteristic granular breaking up of its cells throughout the body, and, in that, the explanation of contagion."

28. This description, translated into philosophical language, exactly fits the class of magnetic spirits already described as inhabiting the astral region of man's system. We have seen that astral spirits are not persons, - that is, they are not in any sense complete entities or cells, for they are protoplasmic merely, possessing no personal soul or permanent element. Yet they may be regarded in many cases as existences, in that they act with apparent independence, passing from one man's sphere to that of another, and behaving with such a semblance of personality as often to get mistaken for true cells or individuals. In them also we recognise the germs and carriers of all spiritual disease of the contagious kind, such as hysteria, preaching epidemics, religious mania, revival panics, and kindred phenomena, so many hundreds of instances of which have abounded and still abound in all countries and under all systems of faith. And it is no small part that the astral spirits have enacted and still enact in the production of "spiritualistic manifestations," by means of the facility with which they personate individuals, and of their faculty for reflecting the beliefs or memories of the inquirer and of the Sensitive, as do mirrors the objects placed before them. In like manner they construct phrases, exhortations, rhymes, and descriptive utterances which, though often marvels of eloquence, are essentially worthless, and partake of the unsubstantial and vapid character of the region whence they are derived.

29. We see, then, in this disintegration of the cell and release of the nucleus, the complete picture of the dissolution of the fleshly body of the man, and of his departure from the earthsphere to wander for a term in a bodiless condition, and finally of his return, saving in rare and special instances, to re-incarnate himself in a new and, generally, a higher form. 


\section{PART III.}

30. Thus does the science of things material and transient present us with the image of things substantial and eternal, and thus does knowledge of the phenomenal minister to the divine Gnosis.

As is the Microcosm, so also is the Macrocosm. As is the Cell, so is the Man, so is the Planet, and so the Solar System. And in all, the order of creation is that set forth in the opening chapter of the truly Hermetic book of Genesis; the work of the "fourth day" being in each the manifestation of the Sun-the nucleolus or Central Spirit of the System-by the polarisation of all the elements of the system. And so of the whole universal Cosmos mystically termed the "Grand Man." The nucleolus is the Macrocosmic God; the nucleus is the Divine Substance, the heavenly Waters upon and within which moves the Spirit or Life, that is, the nucleolus; the protoplasmic fluid is the manifest ether, interplanetary as well as intermolecular, the medium of light, heat, and electricity ; and, finally, the cell-membrane is Matter in its visible and tangible condition.

31. Of these four we know that God and Substance are alone eternal and absolute, Matter and the astral Ether being derived and relative. It is in these last that the infinite Substance particularises itself. The various individual finite forms thus arising, constitute what Spinoza calls Modi. These are to Substance what the waves are to the sea-shapes that perpetually die away, that never are. Nothing finite is possessed of a self-subsistent individuality. The finite individual exists indeed, because the unlimited productive power of Substance must give birth to an infinite variety of particular finite forms ; but these have no proper reality: Substance is the only Real. But that which is true of Substance as a whole, is true also of it in subdivision. Substance individualised is still Substance; and each segregated portion of it undergoes similar changes in respect of manifestation. The error which has arisen in connection with the Spinozic doctrine, consists in the application of the term Modus to the essential self of the individual; whereas the truth is, that this self, being actually divine, and having by the process known as "creation" acquired individuality, is, like God, permanent both in being and in personality, and changeable only as to the mode of its manifestation in Matter. It is this material Modus which is transient and unreal, belonging as it does to that world of phenomenon or illusion, which is expressed in Hinda philosophy 
by the term Maya. That which is real and permanent in the individual, is thus to be conceived of as an integral portion of that divine Self Who subsists at once both as an infinite whole, and in infinite subdivision.

32. In the right apprehension of this doctrine lies the reconciliation of esoteric Christianity with esoteric Buddhism. Esoteric Christianity teaches the everlasting permanence of the acquired personality of every redeemed individual; esoteric Buddhism insists that personality is an illusion belonging to the sphere of Existence, on the ground that permanent Being is necessarily impersonal inasmuch as it is One. The explanation is, that there are to each individual two personalities, the one phenomenal and therefore transient, the other substantial and therefore permanent. And while Buddhism declares truly the evanescence of the former, Christianity declares truly the permanence of the latter. Representing, as does this latter personality, the sum total of all that the individual really is-the Force which animates and the Substance which constitutes himit corresponds, in the organic Cell, to the nucleus; the false, outer personality, vulgarly taken for the real, having its correspondence in the protoplasmic body which falls away and disperses at the break-up of the cell. Recognition between soul and soul will be finally possible only according to the degree of love which, during their passage through the phenomenal, may have united them. For such love only as has been intense and divine enough in its nature to penetrate beyond the mere outer personality into the true being, will be everlasting in duration. All lesser and lower loves, cares, attractions, affinities, or interests belong wholly to the terrestrial, and-when physical disintegration occurs-are abandoned to the astral atmosphere. In this atmosphere they continue to exist just so long as the respective vitality of each particle permits; as in the parenchyma of the tissues do the protoplasmic corpuscles set free by the breaking up of the cell.

33. All principles endure. Whatever during the soul's experience of transient personality has, in any incarnation, acquired the nature of principle, that is, of Being, is ultimately absorbed by and continues to exist in the permanent personality, when, having completed its Kalpa, it is finally redeemed from existence. For principles are essential and therefore indestructible, being indefeasible properties of Deity. For this reason it is said that in heaven everything is personal, the idea of personality being inherent in every molecule of the Infinite Person, the 
return into Oneness with whom constitutes Nirvâna. Redemption is thus exhibited as the final cause of Creation. For therein Existence returns into Being, Phenomenon into Essence, Matter into Spirit; the Universe reverts to its Sabbath of Perfection, and God "rests" from the work of manifestation.

34. It is in fact the acquirement of true personality that constitutes immortality, and therefore Redemption. Perdition consists in failure to attain permanence as a person, and implies therefore dissolution and dissipation; for, as all is of God, annihilation of the substance of things is impossible. Consisting of the substance of God, and differentiated only by mode and not by nature, the creature possesses the potentiality of the Creator, and is capable of attaining to the condition of God. Thus, the nucleolus, or Divine Spirit, appears to be "spontaneously generated " in the nucleus or soul, because all substance is penetrated, suffused, and charged with the Spirit from the beginning; though it is not manifested until the element of the nucleus or soul is polarised in such a degree as no longer to disperse, but to converge, and thereby render manifest, the Divine light subsisting, latent, in its substance. The operation is the analogue of the polarisation of physical light, a process consisting of a certain modification of the luminous ray, by virtue of which, once reflected or refracted, it becomes incapable of reflecting or refracting itself again in any but one direction. This condition of the ray - which under the old theory of emission was founded on the conception of a material fluid of lightmust now be held to depend on the parallel direction assumed by the magnetic poles of all the molecules of ether constituting the vehicle of the ray. In like manner, when the molecules of the psychic element are so directed that their axes all converge to a central point, in accordance with this law of polarisation or gravitation,- which, as has been said, is the one law alike of Matter and of Spirit,-the whole Will of the soul is single, and harmoniously centralised throughout all its elementary molecules. In such a soul the Divine Spirit,-latent and permeant before its polarisation,- - becomes centralised and manifest (fig. 6).

35. The process of polarisation in Matter is itself dependent on the existence and direction of the magnetic forces of its particles. Science has demonstrated the presence, around every material molecule, of particular currents, which, before magnetisation, are indeterminately and heterogeneously directed, and mutually antagonistic; but which, after magnetisation, circulate in such a manner that not only do all assume the same 
direction in parallel planes, but their central points are also all disposed in linear series parallel to the axis of the entity to which the molecules belong, which thus becomes a system of circular currents equal and parallel throughout its mass. Every form of Matter is capable of magnetisation; and every molecule of Matter, therefore, is capable of developing a current of its own, and is necessarily likewise possessed of poles and an equator. These poles, which before magnetisation are heterogeneously directed, assume under magnetisation such a position as to form continuous lines of rays; and the contiguity of the positive pole of every molecule to the negative pole of its immediate successor, constitutes the series a chain of magnetic attraction (figs. 6 and $8, A)$.

36. That which is in physical science the magnetic current inherent in every molecule of Matter, is, in Hermetic science, the Will of the microcosmic individual. The two molecular poles represent the Dual Ego of every personality, 'and the equator the Unity of this duality. In the system of the unregenerate man there are many elementary wills, all mutually antagonistic and destructive, the mind warring against the heart, and the senses against the intuition, so that the man is, as it were, torn by contrary winds, and carried hither and thither by divers passions. And of this condition the result is first spiritual disease, that is, sin, and finally death, that is, dissolution (fig. 8, B).

37. But in the regenerate man one harmonious will prevails throughout the whole being; because of every element therein, the will, which is the spirit, operates in one direction, causing every elementary ego to polarise itself centrally, and thus producing throughout the whole system a regularised series of molecular currents, of which the resultant collective current is the Will of the Man himself. And of this Will,- - united by attraction to the Divine Will, which is the "Universal Magnet," - the central point of radiation is the Microcosmic God, the Adonai of the human kingdom, Himself the Express Image-

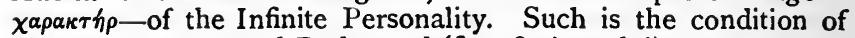
Man Regenerate and Redeemed (figs. 8, A, and 6).

38. By the violation of this harmony is set up Disease, which is spiritual or physical according to the sphere of the disturbance. For the destruction of the polar equilibrium of the cells gives rise to cross magnetisms; and these in their turn cause, in the protoplasmic medium of the cells affected, eddies and other irregular currents which whirl with accelerated velocity 
39. Such also is the generation of the astral incubi and ephemera. It occurs through the disintegration of the collective Will of the system concerned, and the divergence of the parts in different directions, with consequent dispersion of the mental forces, and their dissipation in the Extraneous and Illusory.

40. Neither Disease, nor Death in the ordinary acceptation of the word, could reign in a perfectly polarised entity ; as neither sin nor weakness could be manifest in a soul perfectly harmonised with and obedient to the Divine Will. But, instead of the process of death as we are ordinarily accustomed to see it, with all its attendant horrors of suffering, delirium, and corruption, would be witnessed the "passing away" of the regenerate, in whom the earthly soul has become suffused with the Divine, and every element of the human personality vitalised by Spirit.

4r. The Buddha Gautama, when dying, said to his disciples : "Beloved, that which causes Life, causes also Death and Decay." The allusion was, doubtless, to the operation of the magnetic body, by which is formed the embryon before birth, and by which, likewise, the magnetic forces of the earthly frame are gradually re-absorbed and exhausted. That which puts forth centrifugally, resolves centripetally when its cycle is accomplished. In the healthily born, purely nourished, unpoisoned and undrugged body, death resembles transmutation rather than dissolution. Disintegration of the organism ensues as a result, not of any pathological process, for that would imply physical "sin" of a mortal kind, but of the gradual withdrawal of the animal life into the magnetic, and consequent gradual reinforcement of the latter, precisely as in the cell about to disintegrate, its protoplasmic contents are seen to become better defined and to increase as, simultaneously, their containing capsule becomes more tenuous and transparent. And where the astral, or merely protoplasmic, has itself been in great measure transmuted into psychic substance, the process implies, necessarily, a reversion from the material to the spiritual plane.

42. In such wise have passed away most of the saints and holy men of all lands; and with a dissolution of this kind, the relations of the redeemed soul wlth Matter may terminate altogether. It is the consummation of the redemption from the power of the body and from the sting of death, which is "sin." 5

\section{"Let me die the death of the righteous, and let my last end be like his!"}

5 See Illumination "Concerning Sin and Death" (C.W.S., part ii., No. IV., p. 22I). 


\section{APPENDIX II.}

(Paragraphs 27 to 41 of Lecture VIII. of the Second Edition of The Perfect Way. ${ }^{1}$ )

27. THE true design and method of the Gospels, together with the process of their degradation, become clear in proportion as the nature of their real subject-the Man Regenerate-is understood. In dealing with this we are met at the outset by an example of perversion, one of the most conspicuous and disastrous in the whole history of religion. This is the perversion of the doctrine of the "Incarnation." Of this doctrine the original basis was a prophecy-or declaration of universal import founded in the nature of existence - of the means whereby, both as race and as individual, Man is redeemed. Born originally of Matter, and subject to the limitations of Matter, Man, according to this prophecy, is redeemed, and made superior to those limitations, by being reborn of Spirit, a process by which he is converted from a phenomenal into a substantial being, one in nature with original Deity, and having, therefore, in himself the power of life eternal. Of this perfected Man the foster-father is always that which, spiritually, is called Egypt-the body or Matter, and, by derivation, the Intellect, or reason of the merely earthly mindthe mystic name of which is always "Joseph." On his first appearance in the drama of the soul, as set forth in the Bible, this Joseph is represented as a youth already sufficiently developed, in his affectional nature, to return good for evil and to succour his kindred; in his intellectual nature, to fill with credit posts of responsibility and to secure the confidence of his sovereign; and in his moral nature, to resist the seductions of

1 The corresponding paragraphs of the First Edition were very slightly revised in the Second Edition. They were replaced, in the Third Edition, for the greater part, by fresh matter, " in accordance with wishes expressed and suggestions made by Anna Kingsford shortly before her death" (Life of $A . \mathcal{K}$., vol. ii., p. 33 ; and see Preface). 
the world. $\mathrm{He}$ is, thus, a type of the philosophical element, both in itself and in its relations with the State ; and a representative of the rising Hebrew Mysteries. In the Gospels he reappears-like Egypt itself-aged and past the glories of his prime. And he is represented as the adoptive father only of the Man Regenerate, because this last is really the product, not of the mind, but of the soul ; not of "Egypt," but of "Israel "; not of the "man" Intellect, but of the "woman" Intuition, being "begotten" through her, not by any physical process, but by divine spiritual operation. Nevertheless he has the benefit of the wisdom and knowledge of his "foster-father," for he is instructed in the sacred Mysteries of Egypt, which are, indeed, one with those of Israel, only first of Egypt,- a priority denoting the precedence, in point of time, of the development of the intellect over that of the intuition. In representing Joseph as the foster-father only, and not the real father, the parable implies that Man, when regenerate, is so exclusively under the influence of his soul, or Mother, as to have but a slender connection with his external part, using it only for shelter aud nourishment, and such other purposes as may minister to his soul's welfare.

28. He who would redeem and save others, must first be himself redeemed and saved. The Man Regenerate, therefore, first saves himself, by becoming regenerate. He receives, accordingly, a name expressive of this function. For, of Jesus one of the significations is Liberator. This name is given, not on the birth of the man physical, nor to the man physical,--of whose birth and name the Gospels take no note,-but to the man spiritual, on his initiation, or new birth from the material to the spiritual plane. And it is the name, not of a person, but of an Order, the Order of all those who-being regenerate and attaining perfection-find, and are called, "Christ Jesus" (as see Eph. iii. 15).

29. Of the Miracles worked by the Regenerate Man, some are on the physical, some on the spiritual plane ; for, being himself regenerate in all, he is master of the spirits of all the elements. But while the terms in which the Miracles are described are uniformly derived from the physical plane, the true value and significance of these Miracles are spiritual. That, for example, known as the Raising of Lazarus, is altogether a parable, being constructed on lines rigidly astronomical, and having an application purely spiritual. To a like category belongs also the miracle of the feeding of the five thousand. For the "loaves" given to the multitude represent the general doctrine of the 
lesser Mysteries, whose "grain" is of the Earth, the kingdom of Demeter, and of the outer; and the "fishes"-given after the loaves-denote the greater Mysteries, those of Aphrodite,fishes symbolising the element of the sea-born Queen of Love, and her dominion, the inner kingdom of the soul. It may be noted in this relation, that the Gospels represent their typical Man as at first speaking explicitly to the people, but afterwards, warned by experience, addressing them in parables only. Of the Crucifixon, Resurrection, and Ascension, also, notwithstanding that these have a physical correspondence, the signification intended to be enforced, and which alone is valuable, is spiritual. Wherefore the Gospel narrative, though told as of an actual particular person, is a mystical history only of any person, and implies the spiritual possibilities of all persons. And, being thus, it represents, designedly, that which is general rather than that which is particular, and makes no pretence to an accuracy which is merely historical, the object being, not to relate facts, but to illustrate doctrines.

30. [Reprinted as paragraph 29 of the Third and Present Editions.]

31. In every part of the world of antiquity exist memorials of the Sacred Mysteries and tokens of the ceremonials which accompanied initiation into them. The scene of these ceremonials was generally a subterranean labyrinth, natural or artificial, the object being to symbolise the several acts in the Drama of Regeneration as occurring in the interior and secret recesses of man's being. The Catacombs of Rome, used for similar purposes by the early Christians, were suggestive of the same idea, though this was not the immediate motive for the selection of such a retreat to be the home of the infant Church. And explorers of the passages under the Great Temple of Edfou relate how, after traversing with extreme difficulty a tunnel thirty inches high and forty-two inches wide, they emerge into a large hall adorned with a profusion of sacred paintings and hieroglyphs. Similar excavations have been found at Hermione in Greece, Nauplia, Gadara, Ptelion, Phyle, and other places. And all accounts agree in stating that the Mysteries were variously celebrated in pyramids, pagodas, and labyrinths which were furnished with vaulted rooms, extensive wings, open and spacious galleries, and numerous secret caverns, passages, and vistas, terminating in mysterious adyta. And in describing a catacomb in Upper Egypt, called Biban el Moluk, Belzoni mentions an alabaster chest deposited therein, which, though 
surmised by him to have been intended as a sarcophagus, resembled rather the coffers used in the religious celebrations for which such labyrinths were designed. Similar constructions, of vast antiquity, abound in Upper Egypt, and bear, in their hieroglyphical remains, indications of having been meant for similar purposes. The story of the Labyrinth at Crete, and the Minotaur, who, until finally subdued by Theseus, devoured those who entered therein, is a parable of the Mysteries and the dangerous nature of the ordeals to be encountered by candidates for initiation.

32. But of all existing memorials of these institutions, the most wonderful is that known as the Great Pyramid of Gizeh, the formative idea and purpose of which has for ages baffled inquirers. This artificial mountain of stone is, however, no other than a religious symbol setting forth in its every detail from base to apex the method of that which constitutes the title and subject of these lectures, namely, The Perfect Way and The Finding of Christ. Outwardly, its form denotes the ascent of the soul, as a flame ever aspiring, from the material plane to union with the Divine, and attaining this union through Christ, who, as "the Headstone of the corner," is symbolised by the topmost point of the pyramid, and in whom, as the culmination, completion, and perfection of the whole creation, the earthly is "taken up" into the heavenly, or existence into pure Being. The successive layers of stone form a series of steps from the base to the summit, and represent the various stages of the soul's upward progress in its ascent of the "hill of the Lord";-an idea expressed by Peter when he writes :- "Be ye also as living stones built up a spiritual house, acceptable to God by Christ Jesus. As it is said, Behold I lay in Sion a chief corner-stone, elect and precious." Similarly, Paul says : "Christ Jesus himself is the chief corner-stone, in whom all the building, being fitly framed together, groweth up into an holy temple in the Lord. In whom ye also are built together, into an habitation of God in the Spirit." Thus is the whole intention of Creation, from its lowest to its highest plane, recognised as finding its fulfilment and realisation in the headstone which is at once the Christos and the Chrestos, the "Anointed" and the "Best," being Anointed because the Best, and the Best because the Anointed. In being, moreover, four-sided, like the Heavenly city of the Apocalypse, and culminating in respect of each side in an angle, the Pyramid denotes the fourfold nature at once of the Macrocosm and the Microcosm, and the final assumption of 
each kingdom of nature, through Evolution, into the At-one-ment of Christ. ${ }^{2}$

33. Interiorly, the Pyramid is designed to illustrate, both in character and in duration, the various stages of the soul's history, from her first immergence in Matter to her final triumphant release and return to Spirit. In this view was constructed the complicated system of shafts, passages, and chambers recently described and drawn, after researches involving extraordinary toil, skill, and care, by Professor Piazzi Smyth. Of the two shafts, one, whereby the light from without enters the edifice, points directly to the Pole-star at its lower culmination, 2500 B.C., the date given as that of the erection of the Pyramid. By this is indicated the idea of the soul as a ray proceeding from God as the Pole-star and source of all things, whose Seven Spirits-like the seven stars of the constellation called by us the Great Bear, but by the Mystics of old, more significantly, the Sheepfoldkept watch and ward over the universe, yet ever indicate the Supreme. Of this shaft the opposite extremity terminates in a pit lying below the centre of the Pyramid. Constituting the only portion of the whole structure which is unpaved, this pit represents the bottomless abyss of negation, and, consequently, final destruction. Descending thither, the ray would become extinguished; and such is the fate of the soul which, entering into Matter, persists in a downward course. The Pyramid, however, is designed expressly to represent the way of salvation ; and it accordingly provides a passage turning out of that just described, and leading upwards towards the centre of the edifice, just beyond which centre lies the principal apartment, which is called the "King's Chamber." This is reached by a scries of passages, steep, narrow, intricate, and in some parts so contracted in dimensions as to compel the explorer to traverse them on his hands and knees. Such peculiarities of construction, involving an exercise of great ingenuity, skill, and labour, could not, it is obvious, have been introduced into a structure intended, as some have suggested, as a granary or as a tomb. The "King's

2 The statement of Manetho and Herodotus, that this pyramid was built by the Egyptians under compulsion of a foreign and hated people who obtained temporary dominion over them, may be regarded as due to a literal acceptation of some mystical legend intended to imply that it was built by Egypt's body or State at the dictation of Egypt's soul or Church, by the physical element, that is, of the country, in obedience to the spiritual element, and as a monument in illustration of the power of the soul over the body, and of Spirit working in Matter. 
Chamber," which terminates the series, is a large vaulted apartment having six roofs or ceilings, composed in all of seven stones, placed one above another, the two topmost stones forming an angle. In the centre of this chamber is a coffer, hollowed out of a single stone, and representing in its proportions and dimensions the idea thus expressed in the Epistle to the Ephesians : "When we all meet in the unity of faith and of the knowledge of the Son of God, unto a perfect man, unto the measure of the stature of the fulness of Christ." In a coffer such as this, the candidate who had successfully encountered all the ordeals symbolised in the passages of the pyramid, was, at his final initiation, laid as a corpse in a sarcophagus. And the Initiator, who presided on the occasion, was a woman-a priestess-who was called the "Mother," and who acted as the sponsor representative of Isis, the universal soul and intuition of Humanity. By this funeral ceremony was denoted the death of the candidate to things merely material and sensible, and his attainment of the grade of a Man Regenerate. It has its continuance and correspondence in the rite whereby, in the Catholic Church, candidates for reception into the "religious" life make final profession of the vows which sever them from the world. This burial concluded, as still in the Catholic Church, by the "rising from the dead" of the candidate, who, having quitted the tomb, was invested with the insignia of his new condition, and received the "new" or "religious" name, bestowed by the Sponsor. This name in the Egyptian and allied Mysteries was Issa, the son, by initiation of Isis, and therein child of the Soul, and "Seed of the Woman." Thus was symbolised the gift of eternal life through Christ, the second or new birth of the Man Regenerate, attained only by gradual and painful processes of ascent, extending over many lives, and requiring for their accomplishment desire so fervent, perseverance so great, and courage so indomitable, as not only to deter many of the candidates at the outset, but to turn back some even when far advanced. It is manifestly from the details of this ceremonial, with which, as an "Initiate," the Jesus of the Gospels was familiar, that was derived his allusion to the "Second Birth," and the idea expressed in the warning : "Strait is the gate and narrow is the way that leadeth unto Life, and few there be that find it."

34. Such was the mode whereby was accomplished initiation into those greater Mysteries of which the culminating stage was termed the Ascension. The lesser Mysteries, the "acts" of which were designated the Baptism or Betrothal, the Temptation 
or Trial, and the Passion, are symbolised in the Great Pyramid by the apartment called the Queen's Chamber. This is situated considerably below the King's Chamber, and in the northern section of the building, and is reached by a level passage, at the commencement of which is a precipitous chasm, having for bottom the pit already described, and betokening the fate of those who fail to become regenerate, and consequently the danger escaped by those who have attained initiation into things spiritual. The Queen's Chamber serves also as the "Banqueting Hall," wherein, after his accomplishment of the three acts named, the candidate celebrates the "Solemnisation." $\mathrm{He}$ is then qualified to proceed to the greater Mysteries of which the final scene is the "King's Chamber." This, as already said, is placed at the extreme summit of the passages, and beyond the centre of the Pyramid; and its purpose is to symbolise that kingdom of heaven which the Initiate attains by what is called the Divine Marriage, an act which separates him altogether from his life of the past. The six superposed beams which compose the ceiling of this chamber denote the "six crowns" of the Man Regenerate, that is, the six acts or stages of initiation, of which three appertain to the lesser and three to the greater Mysteries. These "crowns," therefore, are Baptism, Temptation, Passion, Burial, Resurrection, and Ascension. Of all these the ultimate object is that full and complete Redemption which, by its realisation of the soul's supreme felicity, is termed the "Marriage of the Son of God." And in the second shaft passing upwards through the Pyramid, from the topmost point of the last gallery, and pointing in one direction to the coffer in the King's Chamber, and in the other direction to the Pole-star at its greatest altitude, may be seen symbolised the return to God of the soul, perfected and triumphant, on her final release from Matter. So that by the two Pole-star-pointing shafts are typified respectively the forces centrifugal and centripetal, the Will and the Love, from the operation of which proceed Creation and Redemption (fig. 9).

35. Between the "Resurrection" and "Ascension" of the Man Regenerate, is an interval which - in accordance with the mystical system of inaking all dates which relate to the soul's history coincide with the corresponding solar periods-is termed "Forty Days." The actual length of the period, however, is dependent upon individual circumstance. The New Testament contains nothing incompatible with the suggestion that Jesus may have lived on the earth for many years after his " Resurrec- 


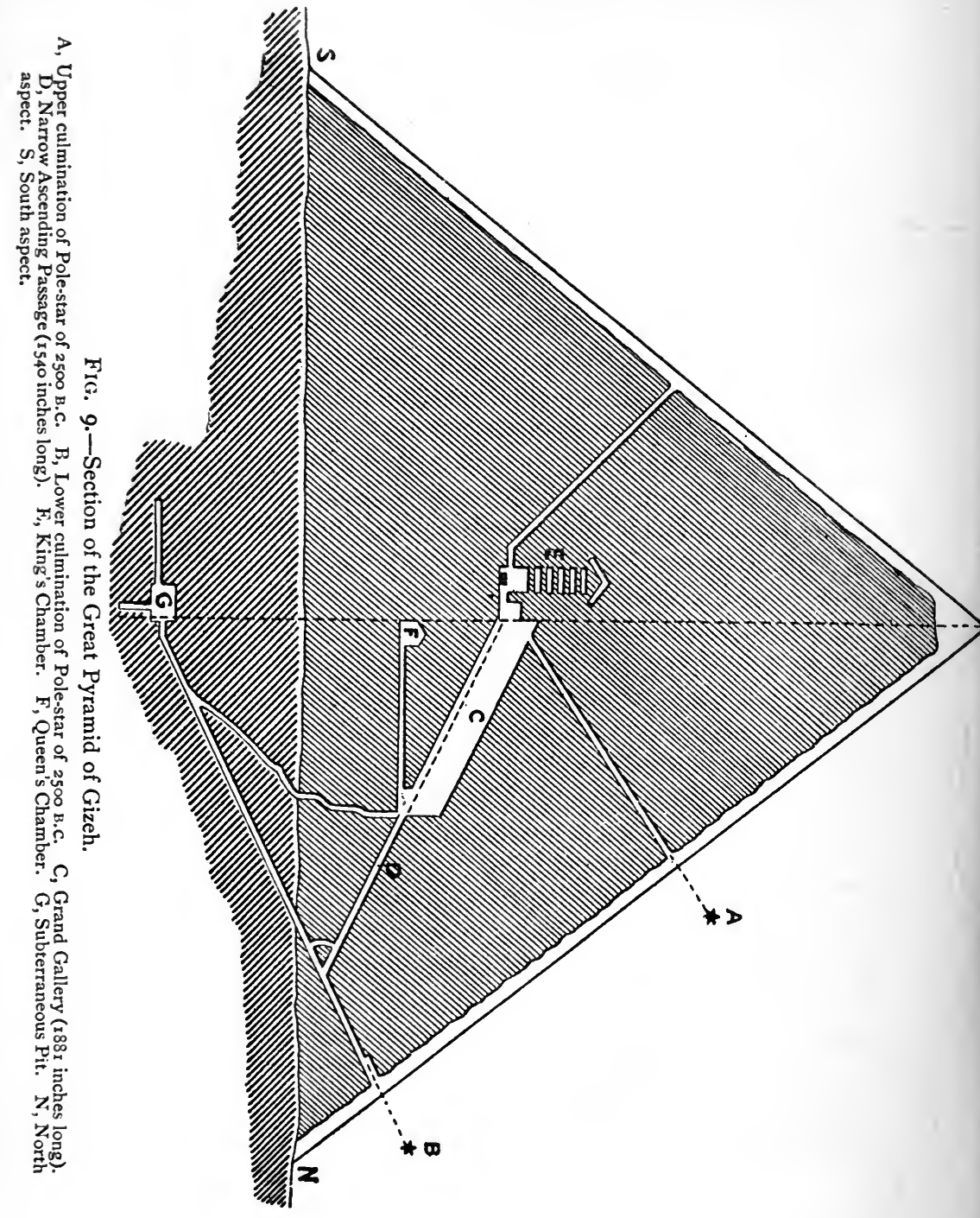


tion," and was therefore still in the body when seen of Paul. For that which occurs at the expiration of this cycle is not a quittance of the earth in the physical sense ordinarily supposed, but the complete withdrawal of the man into his own interior and celestial region. The Spirit attains the Sabbath of perfection only by attaining Rest or Quiescence ; and to this Sabbdth-or Nirvâna-the Man Regenerate necessarily attains, sooner or later, after his "Crucifixion" and "Resurrection"; and the attainment of it constitutes his "Ascension." There are then no longer two wills. The Man has "ascended to his Father," and he and God are One. Henceforth he is Lord of his own microcosmic universe, having the "kingdom, the power, and the glory" thereof. And all things in "heaven" and on "earth" are subject to him. "He hath put all things under his feet, that God may be all in all."

36. But although the true signification of the Gospel narrative of the Ascension is spiritual only, the process of Redemption is not without its physical results; for every faculty is enhanced thereby to the degree ordinarily deemed "miraculous," rendering the Subject clairvoyant and clairaudient, enabling him to impart health and recall life by the touch or by the will, to project himself in visible form through material obstructions, and to withdraw himself from sight at will. And not only is disease eliminated from and rendered impossible to his system, but his organism becomes so highly refined and vitalised that wounds, however severe, heal by first intention and even instantaneously. So that, if only for this reason, it is quite impossible that the Gospels should have intended to represent their typical regenerate man as dying, in a physical sense, of the injuries described by them as received on the cross.

37. By the Crucifixion of the Man Regenerate is denoted no physical or brief exterior act, but the culmination of a prolonged Passion, and its termination in the complete surrender of the soul. And this arrival of the "last hour" of the earthly man, or old Adam, is symbolised by the action of tasting the very dregs and lees of the cup of suffering, - the soul's experience, that is, of the limitations of existence. Accordingly it is written :"Jesus, knowing that all things were accomplished, said, I thirst. And they put a sponge full of vinegar upon a reed, and gave him to drink. Jesus then, when he had tasted the vinegar, said, It is consummated. And bowing his head, he gave up the ghost." By this exclamation is announced the emptying of that cup of spiritual bitterness which may not pass from the Christ until the 
dregs even be consumed. This self-same cup it is of which the symbol, fixed on the summit of a reed, was borne in the hand of an attendant priestess at the ceremony of final initiation as practised in the Mysteries.

38. By this cup is represented the chalice of Existence or Incarnation, wherein is contained that Substantial Water, or Soul, which by the "marriage" of the will of the man with the Will of God, becomes the Wine of the holy Sacrament or Communion with God. The Reed which supports this Cup is the universal Rod or Staff which so constantly recurs in Hermetic Scriptures, and is at once the rod of Moses, the wand of the Magician, the sceptre of the King, the reed of the Angel, the rod of Joseph that flowers, and the caduceus of Hermes himself. For it is the symbol of Force, the Line, or Jod, by which is typified alike the creative act of projection into Matter and individualisation thereby, and the energy of the will-inflexible and undividedthrough which the return to Spirit is accomplished and salvation achieved. Of these cup-surmounted reeds the bearers, in the Greek Mysteries, were called Canephorœ, or reed-bearers. And the corresponding celebration in the Gospels is appropriately described as occurring at Cana of Galilee, where, as may be gathered from Josephus, was a cave of initiation. The nature of the occasion depicted in fig. Io is further denoted by the symbol carried in the right hand, both of the priestess and of the candidate. This is the Crux ansata, or handled cross, called the Cross of Osiris, and already referred to as an indispensable emblem in all religious ceremonials, in that, combining the cross with the circle, it denotes Renunciation as the means whereby Eternal Life, the object of initiation, is attained. This symbol it was which, transferred to Christian hands, became the model of the Papal Keys of the kingdom of heaven; while, mounted on four steps, or traversed by four bars, it indicated also the fourfold nature of existence to be comprehended by those who would attain to perfection. The character of this perfection is, moreover, symbolised in the cross, in that, being formed of two transverse beams, it portrays the at-one-ment between the divine and human wills. The "new-born" is represented as overshadowed by a dove-emblem of the Holy Spirit-as is the Man Regenerate of the Gospels at his baptism of initiation. The two figures on either side of the candidate are, respectively, the male representative of Thoth or Hermes wearing the ram's hornsemblematic of Intelligence; and the female representative of Isis, the initiating priestess, bearing the Rosary of the Five 
Wounds or Decades already mentioned. By the presence of these two, as representatives of the Intellect and the Intuition, is denoted the absolute necessity to the individual of perfecting himself alike in both regions-the masculine and feminine-of his nature, so that by the co-equal unfoldment of head and heart

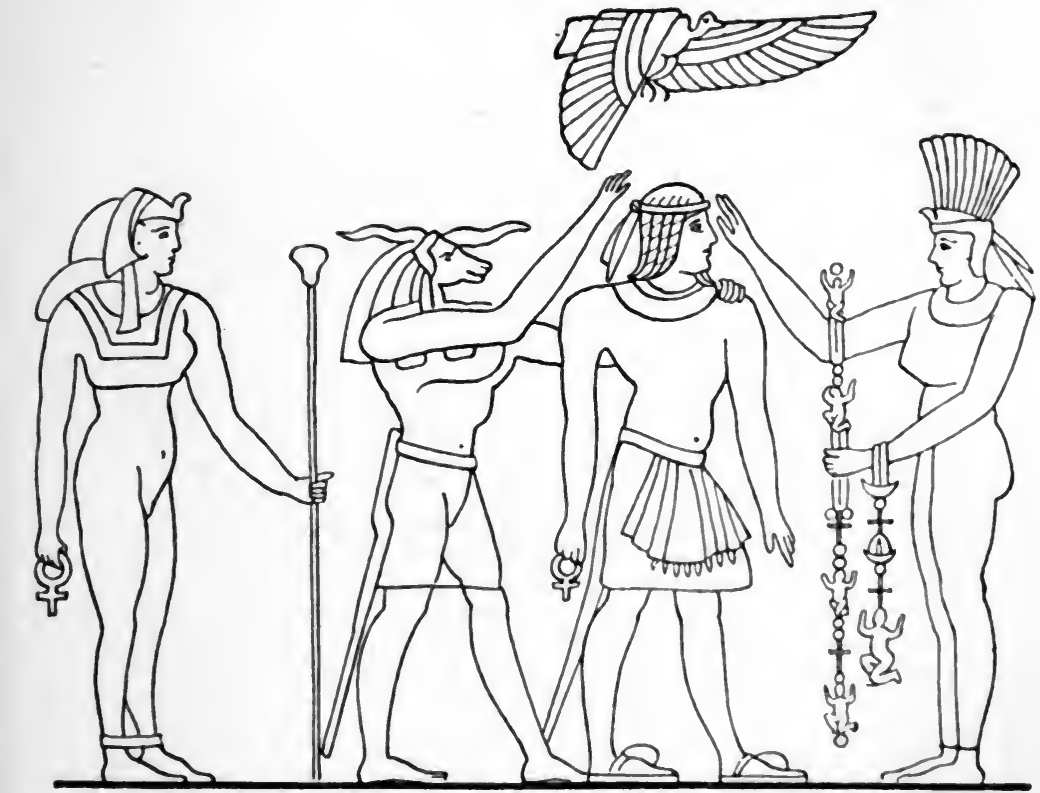

FIG. 10.-Bas-relief in the Temple of the South, in the Isle of Elephantine on the Nile.

he may attain to the stature of the whole humanity. It is the man thus complete and become, spiritually, man and woman in one, that, primarily, is typified by the Greeks under the dual form of Hermaphroditus, the joint child, as his name denotes, of Intelligence and Love.

39. As the last substance tasted by the Regenerate Man of the Gospels before his death on the cross, is the "vinegar" of 
the exhausted Chalice of the Passion, so the first food partaken by him after his resurrection is "fish," to which some add "an honeycomb." By these is symbolised the commencement of the new life inaugurated by the greater Mysteries. For the fish, as already stated, is the symbol of Water, and therein of the Soul, its Greek name ( $i \chi \theta$ vis) being the monogram of the Christ and

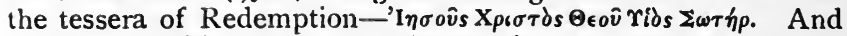
the honey, uniting sweetness of taste with the colour of gold, and contained in the six-sided cell or "cup" of the comb,- typifying the six acts of the Mysteries, - is the familiar emblem of the Land of Promise "beyond Jordan," to which only the Man Risen can attain. For, as the River of Egypt denotes the Body, and the Euphrates the Spirit,-the redeemed man being promised the dominion of the whole region contained within these (Genesis xv. I8), - so the Hiddekel, the Ganges, and the Jordan, in the mystical systems of their respective countries, denote the Soul, and constitute the boundary between the "wilderness" of the Material, and the "Garden" of the Spirit.

40. It is in Jordan, therefore, that the Man Regenerate of the Gospels celebrates the first scene of that supreme act, his spiritual marriage-the Betrothal or initiatory purification by baptism. On this occasion the Divine Spirit announces to him his Sonship; and thenceforth he knows himself divine. The second scene is the Solemnisation, which is celebrated on the "third day " at the Cana of Galilee already mentioned, in the "banqueting hall " of the Mysteries. The whole narrative is constructed on astronomical lines, and in its exterior sense denotes the ripening of the grape and arrival of the vintage season in the month which follows the "assumption" of the constellation Virgo. For then the Sun, or emblem of the Man Regenerate, transmutes the watery element into wine. And this process, though prompted, as it were, by the genius of August, cannot be accomplished save by the genius of September; hence the remonstrance represented as addressed by Jesus to his "Mother." The time of vintage was " not yet come." The mysteries represented on this occasion are those of Bacchus, whose mystic name is Iacchos. And it is the more interior mysteries of Iacchos which really are implied in the parable. For the "beginning of miracles" for the Man Regenerate is always the transmutation of the "Water" of his own Soul into the "Wine" of the Divine Spirit. And the impelling influence under which the change is effected is always the "woman" in the man, his own pure intuition, who is the "virgin Mother of God" within himself. 
41. The third and final scene of the "Marriage" belongs to the greater Mysteries. The "Crucifixion" is the last stage of the lesser Mysteries, and closes initiation into them. Immediately on "giving up the ghost,"-or renouncing altogether the lower life,-the Christ "enters into his kingdom"; and "the veil of the "Temple is rent from the top to the bottom." For this veil is that which divides the Covered Place from the Holy of Holies; and by its rending is denoted the passage of the individual within the kingdom of God, or of the Soul, typitied by the King's Chamber. The first three acts,-the Baptism or Betrothal, the Temptation or Trial, and the Passion or Renunciation,--belong to the Mysteries of the Rational Humanity as distinguished from those of the Spiritual Humanity. The last three acts, - the Burial, the Resurrection, and the Ascension,belong to the greater Mysteries of the Soul and Spirit, the Spirit being the central Lord, King and Adonai of the system, and the "Spouse" of the Bride or Soul. These Mysteries, therefore, belong to the "kingdom of God," and are performed in the "King's Chamber," that is to say, within the veil and in the Holy of Holies. The hour of the "Death" which follows the "Crucifixion" witnesses the passage of this veil; and the exclamation "Consummatum est,"-uttered at this "ninth hour" of "the twelve in which a man may work" in the process of regeneration,-signifies that at length the Kingdom is entered, the King's Chamber attained, the conflict of the Soul crowned with victory. The seventh and concluding act of the whole process follows the accomplishment of the three stages of the greater Mysteries of the King or Spirit, and is called the "Consummation of the Marriage of the Son of God." In this act the "King" and "Queen," "Spirit and Bride," $\pi v \in \hat{v} \mu \alpha$ and $\nu \dot{v} \mu \phi \eta$, are indissolubly united; the Man becomes pure Spirit; and the Human is finally taken up into the Divine. 


\section{APPENDIX III.}

" THE PERFECT WAY" AND ITS CRITICS.

\section{To the Editor of Light. ${ }^{1}$}

SIR,-Permit us space in your columns for a few words in reply to the strictures of Dr. W. and Mrs. P. upon the above book.

The Perfect Way neither is, nor purports to be, a "new" Gospel in the sense implied by your correspondents. On the contrary, it is expressly declared in the preface that "nothing new is told, but that which is ancient-so ancient, that either it or its meaning has been lost-is restored and explained." Its mission is that simply of Rehabilitation and Interpretation, undertaken with the view, not of superseding Christianity, but of saving it.

For, as the deepest and most earnest thinkers of our day are painfully aware, the Gospel of Christendom, as it stands in the Four Evangels, does not suffice, uninterpreted, to satisfy the needs of the age, and to furnish a perfect system of thought and rule of life. Christianity-historically preached and understood - has for eighteen centuries filled the world with wars, persecutions, and miseries of all kinds ; and in these days it is rapidly filling it with agnosticism, atheism, and revolt against the very idea of God. The Perfect Way seeks to consolidate truth in one complete whole, and by systematising religion to demonstrate its catholicity. It seeks to make peace between Science and Faith; to marry the Intellect with the Intuition; to bring together East and West ; and to unite Buddhist philosophy with Christian love, by demonstrating that the basis of religion is not historical, but spiritual ; not physical, but psychic ; not local and temporal, but universal and eternal. It avers that the true "Lord Jesus Christ" is no mere historical character, no mere

1 This letter was published in Light of 23 rd September, 1882, p. 425. 
demi-god, by whose material blood the souls of men are washed white, but "the hidden man of the heart," continually born, crucified, ascending and glorified in the interior Kingdom of the Christian's own Spirit. A scientific age rightly refuses to be any longer put off with data which are more than dubious, and logic which morality and philosophy alike reject. A deeper, truer, more real religion is needed for an epoch of thought and for a world familiar with biblical criticism and revision;-a religion whose foundations no destructive agnosticism can undermine. and in whose structure no examination, however searching, shall be able to find flaw or blemish. It is only by rescuing the Gospel of Christ from the externals of history, persons, and events, and by vindicating its essential significance, that Christianity can be saved from the destruction which inevitably overtakes all idolatrous creeds. There is not a word in The Perfect Way at variance with the spirit of the Gospel of the "Lord Jesus Christ." If your correspondents think otherwise, it can only be because they are themselves dominated by idolatrous conceptions in regard to the personal and historical Jesus, and cannot endure to see their Eidolon broken to pieces in the presence of the Ark of the Mysteries of God.

It is just those who have fully accepted, and who comprehend the Spirit of the old Gospel, who are ready and anxious to hear what the promised Spirit of Truth has yet to reveal. But the world at large never has accepted that Gospel, and cannot accept it for need of that very interpretation which our opponents deprecate. If the Spirit of Truth be really charged to "show all things," such exposition certainly will not consist in a mere reiteration, in the same obscure, because symbolical, terms of the old formulas. But if they elect to close their minds against any elucidation of sacred mysteries other than that provided by a Behmen or a Swedenborg, they virtually quench the Spirit and fossilise its revelation.

Despite the eulogy of Dr. W., Mrs. P.'s letter is altogether inadequate to its intention. Like the utterances of conventional pulpiteers, it is profuse of phrase and meagre of explanation. Terms such as "the water of life," and "the painful mysteries of our own nature," are used wholly without indication as to their meaning ; and the sense in which it speaks of "the Lord Jesus Christ" is left entirely to the reader's imagination. Surely she must be aware that these oft-repeated expressions have failed of their proper practical spiritual issue, precisely because they have lacked the interpretation necessary to render them intelligible, 
and that until they are so explained the world's conversion is not to be hoped for. But, as it seems to us, Mrs. P. is one of those who, contemning knowledge, postulate as the condition of salvation a faith which is divorced from understanding, and which, therefore, is no true faith, indefeasible and constant, but a blind, mechanical assent, born of mere wilfulness, and liable at any instant to fail and fall away.

The secret, however, of the opposition made in certain circles to the doctrine set forth in The Perfect Way is not far to seek. It is to be found in the fact that the book is, throughout, strenuously opposed to idolatry in all its forms, including that of the popular "Spiritualism" of the day, which is, in effect, a revival under a new guise and with new sanctions of the ancient cultus known as Ancestor-Worship. The Perfect Way, on the contrary, insists that Truth is accessible only through the illumination, by the Divine Spirit, of man's own soul ; and that precisely in proportion as the individual declines such interior illumination, and seeks to extraneous influences, does he impoverish his own soul and diminish his possibilities of knowledge. It teaches that "Spirits," or "Angels," as their devotees are fond of styling them, are untrustworthy guides, possessed of no positive or divine element, and reflecting, therefore, rather than instructing their interrogators; and that the condition of mind, namely passivity, insisted on by these "angels" is one to be strenuously avoided, the true attitude for obtaining divine illumination being that of ardent, active aspiration, impelled by a resolute determination to know nothing but the Highest. Precisely such a state of passivity, voluntarily induced, and such veneration of and reliance upon "guides" or "controls," are referred to by the Apostle when he says: "But let no man beguile you by a voluntary humility and worshipping of angels." And precisely such exaltation of the personal Jesus as The Perfect Way repudiates and its opponents demand, is by the same Apostle condemned in the words: "Henceforth know we no man after the flesh: yea, though we have known Christ after the flesh, yet now henceforth know we him no more."

This, then, is the conclusion of the whole matter. God, with "Christ," is in the man who, purifying his spirit after the secret of the Christ, aspires prayerfully and fervently. And it is to this interior spirit that he must look for illumination and salvation, and not to any outside "angel" or fleshly Saviour. Attaining such illumination for themselves, our critics will be able both to recognise the source and to verify the teachings of our book for 
themselves. For, thus invoked, the Divine Spirit will "bring all things to remembrance" for them, even as it has for us. Opinions will be merged in knowledges. And, instead of limiting the Spirit by the form in which its past revelations have been couched, they will be able to discern, in all its plentitude, the Spirit through the form. Your correspondents referred to have, clearly, not yet recognised the source of the teaching to which they take exception. They will find it fully described in Part I. of Appendix 1II. ${ }^{2}$ If the divinity of this utterance is beyond their power of recognition, argument in their case is hopeless, and no avenue exists through which Divine truth can reach them. God grant it may not be so.

The Writers of "The Perfect Way."

\section{"THE PERFECT WAY" AND ITS CRITICS.}

To the Editor of Light. ${ }^{3}$

SIR,-In the number of Light following that which contained Dr. W.'s last letter on the above subject, there is a passage which strikingly exhibits the unsoundness of the position assumed by some of our critics in regard to the historical Jesus and the design of the Gospels. The passage in question consists in a list of parallelisms between the lives ascribed to Buddha, Christna, and Jesus, and might have been enlarged, as is pointed out in the opening pages of The Perfect Way, by the addition of the names of Osiris, Mithras, Heracles, Bacchus, Zoroaster, and other portraitures of the Man Regenerate. And it needs, surely, but an intelligent and unprejudiced examination of these manifold parallelisms to convince the student that the various expressions implying a Divine nature and mission, on which the conventional theology of the Christian Church bases its estimate of Jesus, are simply the stock formula whereby the mystical writers of all times and places have been wont to depict that which they regarded as the supreme object of culture and end of experience, namely, the perfectionment, through suffering, of the typical Man Regenerate; the entire process of the building up

2 The Appendices in the former editions of The Perfect Way, which consisted of some of Anna Kingsford's Illuminations or portions thereof, are not reprinted in the present edition (see Preface). The Illumination here referred to is the one "Concerning Inspiration and Prophesying," published in full in C:W.S., part i., No. ii. (part i.), p. 5 .

3 This letter was published in Light of $\mathrm{x}$ th November, 1882, p. 508. 
of the Christ within the human kingdom. And the very name by which the spiritual and solar hero of the Four Evangels is designated,-Christ Jesus, - is in itself an indication that it is a universal name. Not the name of any one individual, or even of any fleshly personage, but the name by which, in the language of Heaven, all pure and perfected Spirits are called-the Anointed of God, the everlasting "Yes" or "Jesous," who alone have eternal life.

For us the Four Gospels depict the ever-recurring acts of the soul in all ages, her flight from Matter and Illusion, her recognition of the Divine, her reception of illumination, her painful sufferings and passion on the earth-plane, her final triumph and ascension into purer spheres. They are thus, not the record of any one man's actual life, the facts of which, as they stand, are necessarily open to serious dispute and contradiction, but they are a spiritual drama or mystery, setting forth the manifestation of the Son of God in man; the Immanuel, or God within us. And we declare that this mystic and wholly spiritual "God's spell" has been wrested from its true and original meaning by an ignorant or designing priesthood, which, in its inveterate desire to provide the people with a material and human god, palpable to sense, and extraneous to themselves, has persistently misapplied to the fleshly personage, titles, acts, and achievements belonging only to the kingdom of the Invisible and Spiritual. And thus the corrupted Church has committed idolatry as gross as that of falling down and worshipping an image in place of the Lord God.

But we are willing to go so far with Dr. W. as to admit that, inasmuch as it is probable all the mystical histories of various times and countries may each have centred round some special representative, it is likely that the Christian Gospels may, in great measure, have taken shape and spirit from the life and teachings of some fitting model, chosen to exemplify the spiritual possibilities of the human race. We affirm only that what immediately and vitally concerns $u s$ and our salvation are not the acts or the sufferings of this individual, or of any individual soever, but the living of that life ourselves, the suffering of that Cross and Passion in ourselves, the "rising again from the dead and ascending into Heaven " of our own interior regenerate Ego.

So that if it should at any time be proved-what we nowise assert or wish to believe-that the historical Jesus never existed at all, and that everything related about Him is a pure, absolute myth, we should sustain no shock, lose no hold on our faith, and 
retain our position inviolate. And, far from lacking in reverence or gratitude to any one of the many "Captains of Salvation" who have been "made perfect through suffering," we indeed show our regard for these by rescuing the foremost of their number from the category of impossible monstrosities, and reinstating him in that proper humanity which he must have loved so dearly and laboured so painfully and successfully to exalt by showing what it has in it to be.

Religion can never depend for its facts and its hopes on historical data. These, in the very nature of things, are always questionable, and become more and more difficult to verify as the transit of centuries removes us from the epoch to which alone they are related. The real events of religion are not of this world ; its kingdom is interior; its acts are all spiritual and essential. We "must be born again" into another sphere, upon another plane, converted from the material to the immaterial, before we can apprehend heavenly things No one knows this better than Dr. W. himself; yet at times he chooses to write as though, with the mass of uneducated and superstitious Churchmen of the day, he accepted on the material plane the miraculous history of the Gospels, and trusted to the "mystery of the holy Incarnation," "agony and bloody sweat," of the man, Jesus of Nazareth, to save his soul and to endow him with life eternal!

It is against this idolatry that we uncompromisingly contend. The Gospels-and all similar books in all religions - present us, we maintain, with a picture, a guide, a demonstration of eternal and universal processes, illustrated by the history - partially true, but in great part gathered from other previous histories - of one, who, by successive re-births, had attained so high a grade as to constitute him our Elder Brother in a special sense, and to make him worthy of our deepest homage and tender affection. All this-but no more. Even he was not perfect, as the Gospels themselves witness. For one who could pray, "Not My will, but Thine be done!" was plainly not yet in entire union with God. And so it needs must be, for when that perfect union is accomplished, there remains no passion, no cross, no burial to be endured. All re-births are ended, and the spirit is for ever freed from matter. There could not, therefore, by the very nature of things, be any perfect man upon the earth-plane ; because, so soon as perfection is attained, this plane is necessarily incapable of retaining the purified spirit. Wherefore to adore a human being with the adoration due to God, or to look to any human being, whether in the past or in the present, for our own 
redemption by means of any sacrifice he could make of his own body - this is at once idolatry and blasphemy; the first because it places an earthly creature in the place of God; the second, because it directly militates against that immutable principle of justice which is the essential centre-point of Divinity.

Apart from this question of historical religion, there is not a word in Dr. W.'s last letter which we cannot thoroughly endorse. It is so strange to us that he should think otherwise that we cannot avoid giving expression to a lingering suspicion that he has not read our book,--especially the chapters on the "Atonement" and the "Redemption," and Appendix V.4 For surely, in such case, he could not have accused us-as by implication, at least, he has more than once done-of an attempt to create a "new Gospel," differing from that of "Jesus Christ."

To pass to a letter headed, "The Teachings of the Perfect Way," we can but say that the allegation of your Bristol correspondent, that we affirm "the annihilation of the greater portion of the human race," fills us with amazement. "Few shall be saved from that fate," he says, as if citing from our writing. No such passage can we find in the book, unless he refers to the quotation given on one of its pages from the Gospel; to wit, "The way is strait and the gate narrow that leadeth unto life, and few they are who find it" (Lect. VI., par, 24). Your correspondent must know well whose words are these ; but, if their meaning perplex him, it is only because he does not understand them aright. They indeed are few who in any single generation attain to Nirvâna. Only a small number of our race, in any given epoch, achieves the perfection necessary to final beatitude. But the fate of no human soul is pronounced after a single lifetime. They who fail-and who fail again and again, even as the Scripture tells us, until seventy times seven-may be purified by successive re-births, and may thus surely fulfil at last the conditions of salvation, however long and painful may be the schooling required. So far, indeed, from teaching any such doctrine as that ascribed to us in your correspondent's letter, we have distinctly and repeatedly insisted that only the persistently evil, those who all their "seventy times seven" of existences habitually rebel against the Divine Will, and so lose the human spirit within them, sink at last into "outer darkness" and extinction.

4 Appendix V. of the First Edition consisted of a portion of the Illumination "Concerning the Great Work, the Redemption, and the share of Christ Jesus therein," now published in full in C.W.S., part ii., No. 5, p. 224. 
As for our divergency from Swedenborg in respect to the relations of Matter and Spirit, we are not concerned to rebut this statement. And if, indeed, Swedenborg has maintained the proposition cited, we are only too glad to differ, so monstrous to us appears the notion of two original self-subsisting entities, and no single universal elemental essence, of and from which all things are, and to which all can revert. But, may it not be that your correspondent has failed correctly to apprehend Swedenborg's meaning, precisely as he has failed, so singularly, to apprehend ours on another point? We trust so, for we have great respect for Swedenborg, though not unaware of his limitations.

To conclude with a reply to the Hon. R. N.'s objection to our statement respecting the compound constitution of man, we think his difficulty is due to his not having taken into account the various gradations into which the central-essential Ego differentiates its consciousness, according as it subsists in the outer or the inner spheres of the individual system. Thus, while all consciousness is, originally, that of the Spirit, each separate element, body, astral soul, and anima divina, possesses a consciousness of its own, suited to its character and needs, making each of these, in a sense, a distinct personality, and enabling them each to subsist apart from the others, though, in the case of the body, for a short time only. Body, soul, and spirit are thus, not precisely one, but they "agree in one," as declared in the Hermetic formula cited in Lecture I., par. 30. And when severed, each represents and retains, so long as it survives, the functions exercised and the characteristics presented by it when in combination, so inveterate is the principle of personality in the substance of existence. Should our critic ask for some handy illustration of the mystical truths just indicated, we would remind him of the natural order known as the articulated animals, of which every segment possesses an independent life of its own, and if separated from the body of which it forms part, continues to exist and even to reproduce itself for a period more or less long. This rough comparison may serve to convince him that at least the idea he finds so much difficulty in accepting is neither monstrous nor without parallel in Nature. The subject is, however, too intricate and lengthy to be adequately discussed here. All that we have advanced respecting it has been, for us, amply verified by our own independent experience. And if Mr. N. will carefully examine certain passages in our second Appendix, "Concerning the 
Hereafter," 5 and compare them, not with any preconceived opinions, but with any actual experiences he may have, he will, we are confident, be sooner or later at one with us.

Since writing the above we have read, in the current number of Light, two letters, one of which, like that from Bristol, fills us with amazement, and the other with a sentiment akin to indignation. It is now beyond doubt that several of our wouldbe critics have not read-perhaps have not even seen-the book they are so eager to decry!

"R. J. S." misquotes in representing us as saying that Paul was only or always "in the astral," and, therefore, altogether unworthy of heed. What we have said is that "Paul, whose teaching and character are in many respects of the noblest, was not uniformly enlightened, but oscillated between the astral and the celestial, mixing error and truth accordingly." This he himself, by implication, admits when he says that he sometimes wrote "as a man," or even "as a fool," and that at others he only thought he had the sanction of the Divine Spirit for his assertions. Had Paul but acted on his own advice in regard to the necessity of "discerning spirits," and expunged before dis. semination all that he wrote from the lower level, he would certainly not have left it in the power of "R. J. S." to cite him as an authority on behalf of the inevitable brutalities of the slaughter-house or the revolting and inhuman practice of corpseeating. As it is, the very fact that Paul found it necessary to interfere in this matter between two differing schools of the Church, proves that the conviction and practice in regard to flesheating were far from uniform among professing Christians, and that no inconsiderable number of them refrained on principle from bloody meats. And, if we listen to tradition, and study such historical memoranda as we possess on the subject, we shall find that Paul himself was the innovator, and that the general habits and teaching of the early Church were Nazarene or Essenian, and therefore vegetarian. Jesus the Nazarene must certainly have been an abstainer from flesh and strong drink, and even the statements in regard to His custom of eating fish are, as one of us has elsewhere demonstrated, ${ }^{6}$ not literally, but mystically intended. James, the "brother" of Jesus, and one of his most familiar associates, is universally reputed to have been a vegetarian, and so also was

5 Now published in C.W.S., part i., No. xl., p. 156.

${ }^{6}$ See note to letter, p. 35I, post. 
an innumerable company of the early saints, both men and women. The stricter devotional Orders of the Catholic Church, like those of all other divine Mysteries, have always abstained from flesh; and, Paul notwithstanding, this unbloody and innocent diet has from the beginning been regarded by all Adepts as constituting "the excellent - or perfect - way." Certain it is, that the prophecy of Isaias-" They shall not hurt nor slay in all My holy mountain "-will never be realised by those who persist in destroying and devouring like beasts of carnage. How shall we hasten the restoration of Paradise by continuing the manners of the Fall? If we truly and earnestly desire to regain the Golden Age, and to become citizens of Heaven, we must begin by adopting the new life, and by returning to natural and human modes of sustenance. The eating of blood, and the habit of slaughter, are part of the Fall, and came with it. We, of the new Life, desire to return to Eden. And, as a first step thither, we abandon that horrible and degrading custom which has so long assimilated our race to that of the lowest types of bestial existence; we reject the offal which delights the wolf and the swine, and turn instead to the pure sun-created fruits and grains, unbloody gifts of fragrant trees and fields, for which alone the anatomy of man is fittcd. We cannot err in following the indications - nay, the commands, $\rightarrow$ of nature, for these are the surest words of God.

"R. J. S." seems to argue that the superiority of certain races is due to their habit of flesh-eating. As well might he assert it to be due to their not less universal habit of dram-drinking. Both habits are equally abuses and drawbacks, and have doubtless withheld these very races from the higher and interior civilisation they have hitherto invariably and significantly failed to reach. For there can be no true and perfect civilisation without sympathy and solidarity between all the children of God's family, and without the recognition of the fact which must be the basis of that solidarity, - that the same Spirit breathes in all, that the same Destiny is over all, and that the same Immortality is the heritage of all, no matter on what round of the ladder each individual soul, at any given time, may stand. To kill, to devour, or to torture any sentient fellow-being for a selfish end, is a breach of the law of solidarity, and there is but a question of degree between the murder of an ox and that of a man (Isa. Ixvi. 3).

In the insinuation that we claim to give "higher teachings than those of Jesus Christ," "R. J. S." simply repeats Dr. W.'s 
curious misapprehension, already amply exposed. For, as we have said, far from making any such claim, our whole endeavour has been to interpret those very teachings in the Spirit of Christ, and to restore their meaning perverted by superstition and ignorance.

Against the use of wine we have said nothing; on this subject we leave "R. J. S." to make peace between Paul and the Nazarenes, to whose number Jesus, John the Baptist, and many a saint and hero of the Old Testament, belonged.

In answer to the desire expressed for a "proof" of our doctrine, in the shape of "miracles," we would point to Lecture I., pars. $24-5$, in exposition of the fallacy underlying such a thought. Spiritual truths cannot be demonstrated by physical phenomena. According to the Gospels, few of those who witnessed the miracles of Jesus were persuaded by them to accept his doctrine. And of the events described as miracles, the chief are but parables relating to the Mysteries, and thus recorded in order to ensure their concealment from the uninitiate. Moreover, physical miracles can be performed by agents other than divine; and as they are also liable to be simulated, they involve more than one element of uncertainty.

The only really satisfactory "miracles" are those which are intellectual, solving problems of man's nature and history hitherto regarded as inscrutable, and reconciling difficulties, the failure of the orthodox Church to interpret which, has been long a prolific source of unbelief. Such miracles as these, at least, cannot be simulated, nor can they proceed from intelligences other than divine.

It is possible that some of the extravagant charges so gratuitously made against us by various "critics" may have been devised with the view of testing our patience. If this be indeed the case, the ordeal has surely been severe enough, and may be regarded as complete. It is incomprehensible to us why a book so plainly, clearly, and lucidly written as The Perfect Way,-a book differing so entirely from the mass of mystic literature, by its freedom from obscure and ambiguous expressions, - should be, in good faith, so persistently misunderstood and mis-quoted.

THE WRITERS-NOT THE "AUTHORS"-OF "The Perfect Way, or The Finding of Christ." ?

7 Several of your correspondents mistake the title of our book, and call it "The Perfect Way to the Finding of Christ." 
"THE PERFECT WAY" AND ITS CRITICS.

To the Editor of Light. ${ }^{8}$

SIR,-It is necessary to give a reply, which shall be made as brief as possible, to the questions and statements made on the above subject in a letter printed in a recent issue of Light, under the heading, "Teachings of The Perfect Way."

Most modern Christians believe that Jesus ate not only fish, but flesh, and this impression constitutes for them clear licence and sanction to do likewise, although a careful examination of the Sacred Writings, and a scrupulous comparison of the various statements made in the Gospels, would go far to convince them that the probabilities of the case are strongly in favour of a wholly different view.

In the second chapter of Matthew it is stated that Jesus was a "Nazarene." The fact that the writer refers to prophecy for his authority plainly shows that he means not a Nazarene in the sense of a mere inhabitant of Nazareth, but a "Nazarite," for the reference made can only be to the declaration of Jacob (Genesis xlix. 26), in which the word natzir occurs for the first time in the Bible, and in the Protestant version is translated "separate"; to the directions given by an angel to the mother of Samson; and to the vow of Hannah in regard to Samuel. According to ecclesiastical tradition, a Nazarene or Nazarite appears to have been one who wore his hair long, clothed himself in a single outer garment without seam, abstained from fermented drinks, and, in the higher degrees of the order, as among the Essenes, from flesh-meats also, after the manner of John the Baptist. The belief that Jesus was one of this order is not only supported by Gospel statement, but by legendary art, based on early conviction

8 This letter was published in Light of 9th December, 1882, p. 551. The greater part of it follows (almost verbatim) a letter of Anna Kingsford "On Pure Diet," in The Food Reform Magasine of October, 1881 (vol. i. No. 2, pp. 46-50); and, in the next following number of the same magazine (January, 1882, p. 100), Anna Kingsford said that the sole olject of her criticisms and interpretations was to suggest to conscientious Christians a ground of reconciliation between the tenets of their faith and the practice of vegetarianism, so that they might not fancy themselves forced to conclude that religion sanctioned and even isculcated that which their own secret sense of morality condemned ; for, she said, "It is a serious difficulty to be unable to regard the personages whom sacred tradition presents to us as types of perfection, as failing in respect of one of the chicf articles in the moral code by which they regulate their own lives." $-\mathrm{S}$. H. H. 
and doctrine, as is conclusively shown by all the Christian representations of the Master, depicting Him invariably in the Nazarite garb, with flowing hair and beard. That $\mathrm{He}$ was an adherent of John's doctrine appears further probable from the fact that He sought and underwent baptism at the hands of the latter, and the very word "Essene" is derived from a root signifying "Bather." To be "bathed" was, therefore, to profess Essenism.

There is no evidence, written or traditional, that Jesus ever partook of flesh. The phrase, "the Son of Man is come eating and drinking," is plainly shown by the context (in the revised edition) to refer to the eating of bread; and it implies that Jesus did not push abstinence to asceticism, as did John. The Paschal Lamb difficulty (in connection with the Last Supper) arises out of a simple misunderstanding, easily rectifiable. The Last Supper is shown in the Gospel of John, who himself was a prominent figure on the occasion, ${ }^{9}$ to have taken place on the evening of the thirteenth day of the month of Nisan, that is, as is many times distinctly affirmed, before the day of the Paschal meal, which was the fourteenth of Nisan. On this latter day (Friday) the Crucifixion itself took place, for we are told in all four Gospels that this event occurred on the preparation day of the Sabbath, which Sabbath, being also the Convocation day, was "an high day." The date of the Crucifixion is unmistakably fixed by John in the verse: "They led Jesus, therefore, into the palace ; and it was early; and they themselves entered not into the palace, that they might not be defiled, but might eat the Passover."

That the Crucifixion took place the day after that of the Last Supper is clearly stated by all four Evangelists, and this fact affords plain evidence that the mention of the "eating of the Passover" in relation to the Supper is an erroneous interpolation, for all of them agree that it was held on the thirteenth of Nisan (Thursday), on which day the Passover could not have been eaten.

In calling attention to these facts, over which Biblical students have been much and hopelessly exercised, we cannot refrain from once more pointing out the uncertainty of the historical data of the Gospels, and the danger-exemplified in your correspondent's letter-of citing from "the plain, clear, unmistak-

9 This observation is not less pertinent if we suppose the Fourth Gospel to have been written, not by John, but according to John, for in either case it would record his version of the event in question. 
able record" of one Gospel narratıve, a statement which is flatly contradicted by another of equal or even greater authority.

But that Jesus ate fish, is, if these Gospel records are to be accepted in their literal sense-an assumption we emphatically contest-pretty well established. Let your correspondent bear with us while we point out the strong indications which exist why the fish-eating and fish-catching attributed to Jesus and His disciples, have, not a literal, but a parabolic and mystic meaning, precisely as have also the many references to the "cup" and to wine-drinking in the same narratives. All these allusions are related to astronomical symbology, and identify the Hero of the Christian Evangels with His ancient prototypes.

It is admitted by most critics of the Sacred Scriptures, that they are largely based on and governed by reference to that science which in earlier times, and in Eastern lands, - whence both the Hebrew and Christian oracles are derived,-dominated and directed all expressions, whether tabular or written, of psychic truths. This science was founded on the study of the Celestial Planisphere, and its earliest and most universal textbook was the Zodiac. The phenomenon known as the Precession of the Equinoxes, causes a different sign in the Zodiac to appear at the vernal equinox about every 2000 years, and to the character of this vernal sign prominent expression was given by the initiated, in the theological cultus of the period. Thus, history has shown us successively the Bull (Apis) and the Lamb (Aries) as the dominant emblems of Egyptian and Jewish worship ; and this latter sign has survived in Christian symbolism because Aries is always the first Zodiacal hieroglyph, and thus the permanent emblem of the one eternal year or great sun-cycle. But the sign which actually ushered in the Christian dispensation, and which therefore we should expect to find reflected in the sacred legends of the period, was $P$ isces, or the fish.

Hence the Messiah, who appeared under the auspices of this sign, is portrayed as being followed by fishers ; as distributing fishes (the "two small fishes" of the Zodiac) to His disciples; as preparing fish for the food of His Apostles; and as Himself partaking of fish after His resurrection.

Besides, the fish is the maritime emblem, and Jesus is said to have been born of Maria and the Holy Ghost, or of Water and the Spirit. The prophet Esdras (Esdras, Book II., chapter xiii.) sees Christ in a vision coming up out of the sea; and the ceremony of "passing through the sea and the cloud" is still connected with the initiation into Christian doctrine.

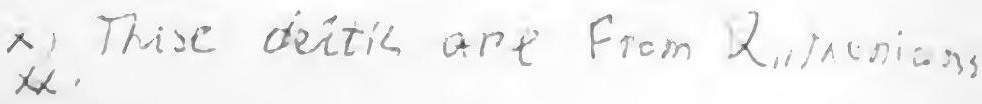


For these reasons, the Kingdom of Heaven is likened to a net, and the Apostles are told they should be "fishers of men." Clement of Alexandria writes to his people early in the third century: "Let our signets be a dove (the Holy Spirit), or a fish (symbol of the water), or the heavenward sailing ship, or the lyre (of the sea-nymph), or the anchor." All these symbols are found in the celestial planisphere.

In the Roman catacombs-the home of primitive Christian art-the most remarkable and the most general symbol employed to express the name of Christ was that of the fish, which affords, significatively, a combination of everything desirable in a tessera, or mystic sign. The Greek word for fish-IXer ₹-contains the

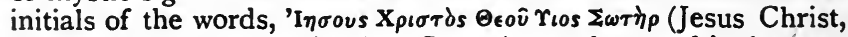
Son of God, the Saviour). Sometimes the word 'I $\chi$ tus 'was written at length in place of the graven symbol.

Augustine also applies this emblem to Jesus, and says that "He is a Fish which lives in the midst of waters." Paulinus, speaking of the miracle of the five loaves and two fishes (the mystic number of the planets), alludes to Jesus as "the Fish of the living waters." Prosper refers to Him as "the Fish dressed at his death." And Tertullian calls the Christians "fishes bred in the water, and saved by one great Fish." Jerome, commending a disciple who sought baptism, tells him "that like the Son of the Fish, he desires to be cast into the water."

As thus the Messiah of the Gospels is associated with the sea and with redemption through and by water, so, with perfect reason, the successors of Peter, His chief apostle and vicar, claim as their distinctive title the name of the "Fisherman," and the ring with which each successive Pontiff is invested, in token of his office and authority, is known as the "Fisherman's Ring." It has been observed also, that the mitre, characteristic of ecclesiastical authority in the Christian Church, represents a fish's head, and expresses, therefore, the relation of the wearer to the Founder of the religion inaugurated under that sign. Fish were connected in primitive Christian times with all theological ceremonies; the saints in the sacred mysteries were called "pisciculi"-little fishes, - and to this day the water vase at the entrance of Catholic Churches bears the name of "piscina."

The custom of eating fish on Friday, in commemoration of the chief event in the history of Him whose Mother is identical with the genius of that day, is still common in the larger section of Christians. 
We might insist at greater length on the peculiarly symbolical character of the whole 2 Ist chapter of John's Gospel, containing the account of the final fish-miracle, which chapter is appended as an epilogue to the Gospel itself, whose formally concluding verse closes the preceding chapter.

More than one critic has pointed out the strong probability that the episode referred to, with its curiously emphasised numerals, - seven, two hundred, a hundred and fifty and three,and the unlikely character of its literal interpretation (see the Rev. Malcolm White on the symbolical numbers of Scripture), is altogether mystical and, perhaps, prophetical in meaning.

But enough has been said to indicate the reasons for attaching a sense, not historical but symbolical, to the various statements contained in the four Gospels on the subject of Christ's connection with fish and fishery, and the reason of the substitution of the fish for the lamb, which represented the former dispensation.

His connection with bread and wine is equally mystic in its character, and needs no explanation for those who are acquainted with the facts and doctrines of ancient mythology and the relation of the latter to the religion of which they are the lineal ancestors.

We entirely deny that we have "heaped loose and indiscriminate imputations on the ministers of the Gospel." For the true "ministers of the Gospel" we have no words of blame; we spoke of "priesthoods and of their inveterate tendency to materialise spiritual doctrines," not in the Christian religion only, but in all others. ... The Resurrection of Jesus is not held by Christians of any recognised Church to have been a spiritual resurrection. Both Catholic and Protestant divines have invariably taught that Jesus rose from the dead in the body, in that body appeared to His disciples (Luke xxiv. 39), and with that body ascended into Heaven, where, in that body, He sits at the right hand of God the Father. If "S. C." holds otherwise, he cannot believe the letter of the Scriptures, nor the Articles of the orthodox faith, of both of which he appears to be the champion. As it is, while spiritualising the Resurrection, he seems to ascribe a physical meaning to the Incarnation.

As regards the doctrine of re-births, "S. C." writes as though we had been the inventors, or, at least, the first promulgators of that doctrine, which, he ought to know, is so ancient that upon it all the early theosophies and philosophies were built. It is 
really too late in the day to discuss a doctrine which is nowsince the publication of The Perfect Way-openly taught and at great length insisted on in the pages of the Theosophist, and which has but very recently been clearly expounded in Light by "C. C. M." If "S. C." is not content with these, he may turn to some letters on "Re-Incarnation" published in Light a year ago, ${ }^{10}$ under the signature "Anna Kingsford, M.D." He will there find plainly set forth the true nature of that doctrine, which, in common with most Spiritualists, he wholly misunderstands. In passing, it is, however, well to remind him that Spirit is Divine in its nature, and therefore, of course, possesses and includes the dual principles. Hence Spirit incarnate must needs comprehend the potentiality of both sexes. Were it otherwise, the "perfected man" could not be in the image of God. A full humanity must comprise all experiences and all human relations. Otherwise all would be disorderly, unsystematised, and unequal.

As last words on this controversy, we wish to say generally that we have never put forward any "hypotiesis " or "opinions." We have taught, and shall still teach, the doctrine of all mystic adepts from Hermes Trismegistus to the Theosophists of our own century, a doctrine given to us by precisely the same method as to all who live the requisite life. And the rule of that life we have openly proclaimed in both precept and practice. We have been asked by some to show our credentials for our authorityto give a sign of the truth of our doctrine. Our answer is that the whole of that doctrine, in its minutest details, was obtained independently of any initiation at human hands, independently of any previous study in contemporary schools of Occultism, and by a method so clear, so luminous, so divine in character, as to leave no doubt of its source in the memory of the interior Ego. And since the book which contains this doctrine has been given to the world, it has been made abundantly clear that the recipients of the most venerable traditionary teaching in the worldthat of India - are in perfect accord with us. Re-birth, in manifold existences, both on this planet and in others, the complex nature of the human kingdom, the inevitable relation of cause and effect, the superiority of vegetable over flesh food, respect for innocent animal life, the spiritual character of all mystical scriptures, conditional salvation,-all these, and the minor teachings they involve, are now being made public by those from

10 In April, $\mathbf{8 8 2 .}$ 
whom we had no possible means of learning them, withheld, as they have hitherto been, from even the admitted disciples of the Adepts on whose authority they are now declared.

There has, then, been neither appropriation nor invention in the case ; there has been recovery only, and this not by the mediation of "Spirits," but through interior recollection. Thus the book is in itself, as one of your correspondents has suggested, a proof at once of the doctrine of Re-incarnation and of the soul's ability to regain and communicate of its memories of the past. And it is upon the appeal of such intrinsic evidence to developed and instructed understandings that we rely for the recognition and appreciation which are its due.

THE WRITERS OF "THE PERfECT WAy." 



\section{INDEX}

\section{OF SUBJECTS AND PRINCIPAL WORDS.}

The Roman numerals refer to the number of the Lecture, or of the Appendix; the Arabic numerals to the paragraph quoted; App. is for Appendix; Pref. for Preface to Present Edition; Pref. F.E. for Preface to First Edition; Pref. R. E. for Preface to Revised Edition; Pt. for Part; and $n$ for footnote.

Abraham, Brahma, viii. 51 .

Children of, i. 33 ; vi. $1,2$.

Acts of Soul, vi. 2 ; viii. 28 ; App. ii. $34,35,37,41$.

Adam, iv. 31 ; v. 10 ; vi. 1, 2, 15 , $19,20,22,25,32$; vii. 20,21 , 32 ; viii. 27,41 ; ix. 9, 20.

Adam Kadmon, ix. 5, 18.

Adam, Old, iv. 24 ; viii. 7 .

Adept, iv. 30 ; v. 39 ; viii. 12.

Admetus, his oxen, ix. 16.

Adonai, vi. $4,5,36$; viii. 14 ; ix. 5 , $8,41,42,46,50-53$.

Advent, vi. 39.

Affinity, Celestial, iii. 40.

Agnostic, ii. 39 ; v. 27 ; vi. 29.

Agnosticism, Pref. ; Pref. F.E.

Alchemic Science, ix. 12.

Alchemists, viii. 43.

Allah, viii. 53 .

Alpha and Omega, Pref. R. E. toii. v. 18 ; ix. 5 .

Ambrose, vi. 8.

Amoeba, v. 2.
Amun-Ra, vi. 15.

Anael, ix. 27, n.

Andromeda, Pref. F.E.

Anima Bruta, ii. 21, 24 ; v. 25, 26,

35 ; vii. 14 ; App. i. 26, 32.

Divina, ii. 24 ; vii. 14 ; viii. 42 .

Mundi, v. 39.

Animals, ii. 18; iii. 21; vii. 53; App. i. 19.

First appearance of, i. 40.

Anna, v. 43.

Annihilation, ii. 17 ; vii. 17 ; App. i. 34 .

Antichrist, iv. 28 ; viii. 53 ; ix. 23.

Anubis, ix. 15.

Aphrodite, ii. 35 ; v. 40 ; viii. 28.

Girdle of, ix. 16.

Apocalypse, vi. 3 ; vii. 27 ; viii. 34, 36, 41, 43 ; ix. 2.

Apollo, Arrows of, ix. 16.

Apollonius, i. $3^{8}$.

Apollos, iv. 9.

Arche, ii. 34 ; v. 4,14 ; vi. 6,31 .

Ardha.Nari, ix. $5,52$. 
Argus, ix. I 3.

Aristotle, ix. 25.

Arjun, viii. 12 ; ix 3,52 .

Ark, ii. 37 ; vi. 3 ; viii. 44 .

Arnold, Edwin, iv. 15.

Matthew, Pref. R.E. liii.

Artemis, ii. 35. See also Diana.

Arthur or Ar-thor, viii. 44.

Ascension, Pref. R.E. lix ; viii. 8, 28, 40; and Descension, iii.

53 ; iv. 31 ; vi. 2.

Asceticism, viii. I4.

Assumption of Virgin, Pref. R.E.

$l x$. ; v. 44,45 ; viii. 40.

Assyria, vi. 6.

Astræa, vi. 36 ; vii. 55 .

Astral Body, ii. I3; iii. 2, 4.

Fluid, i. 26 ; ii. 21.

Medium, iv. 16.

Phantoms, iii. 28.

Plane, ii. I4.

Soul, v. 35, 4I.

Sphere, v. 37.

Astrals, App. i. 28.

Athanasius, Pref. $i i$.

Atheism, Pref. vii ; i. $55 e$; ii. 24 ; vi. 29.

Athena, Pref. F.E.

Atman, i. 7.

Atonement, iii. 3 ; iv. I, 16, 20; vi. 39 ; viii. $4,6,47$; ix. 22.

Current Doctrine of, iv. 3 .

Fourfold, iv. 2, 20.

Augustine, i. 45 ; viii. 39 .

Avatâr, ii. 24 ; v. 4 I.

Azote, Heb. Azoth, ii. 20.

Baalzebub, ii. I8.

Babylon, Pref. F.E. lxviiz.
Bacchos, v. I6; viii. 52.

Baptism, iii. 53 ; vi. 2 ; viii. $19,28$. or Betrothal, viii. 28. with Fire and Water, i. 7.

Baptist, viii. 38, 49.

Bath-Kol, i. 25.

Beatific Vision, iv. 19.

Bells of High Priest, iv. I3.

Bethel, vi. I.

Beyond, The, iii. 3.

Bhagavad Gîtâ, ix. 3, II.

Bible, Pref. ; ii. 46 ; vi. 9 ; vii. 18 ; viii. 53.

Biblical Interpretation, Pref. xii ; vii. 33 .

Requisites for, i. 47.

Biologist, v. 33 .

Biology, ix. 17.

Birth, Second or New, v. 45.

Bitterness, Sea of, ii. 36 ; viii. 32. Blavatsky, Isis Unveiled, iv. 12, n. Blood, iv. 12 ; vi. 32,42 ; vii. 29 , 52 ; viii. 10 .

of Christ, mystical, iv. 19, 23, 25. Partakers of, iv. $6,8,19$; vi. 24.

Bloody Sacrifice, iv. 6, I1-15, 19.

Body, vi. 20 ; viii. I, 3, 13, I4.

Fourfold, iii. 4.

Redemption of, ix. 54 .

Boehme, iii 33.

Book Worship, i. 24.

of Revelation, vii. 19. See also Apocalypse.

Borrowing of Egyptians, vi. 12.

Bow, Heavenly, vi. 36 .

Brahma, vi. 2 ; viii. 5 I, 52 ; ix. 52. Bosom of, iii. 16.

Bride, The Soul as, v. 14; viii. 4I, 43. 
Buddha, i. 44 ; ii. 46 ; viii. 12,25 , $49,50,51$.

Buddhism, v. $43, n$.

Burial, vi. 2 ; viii. $8,28$.

Butler, S., v. 2, n.

Cresar, viii. 36.

Caiaphas, iv. 9.

Cain, iii. 21 ; vii. 52.

Caithness, Lady, Pref. xxix, xxxiv. Caleb, ix. 15.

Calvinists, vi. 21 ; ix. 27.

Cana, iii. 50 ; iv. 25.

Carpocrates, i. 39.

Catholic Doctrine, v. 43.

Causes and Effects, World of, v. 8.

Cave, viii. 37.

Cell, Physiologic, i. 10, 27 ; v. 15 , 34 ; viii. 44,48 ; App. i. 5 , 11-15.

Fixed and Wandering, App. i. 21-24.

Centurion, iii. 35 .

Cerberus, viii. 22.

Cerebration, Unconscious, v. 33.

Ceremonial Rites, iv. 7.

Ceylon, viii. 50. n. 1 .

Chaldrea, viii. 52.

Chalice, iv. 25. Golden, vi. 42 ; vii. 3 .

Chaos, vii. 13.

Character as Destiny, ii. 25.

Chastity, viii. 20.

Chaugcer, v. 35, n.

Chavah, vi. 15, 23, 31 .

Cherubic, iii. 4.

Cherubim, iii. 36 ; vi. $2,4,13$; ix. 49.
Christ Jesus, i. 42,50 ; iv. 8,27 ; viii. 27,51 .

The Advent Millennial Reign of, viii. 54 .

The Blood of, iv. 25.

Christ, The, Pref. i-iii; Pref. R.E. lix; iii. 14,53 ; iv. 26,27 ; vi. 15,39 ; vii. 18,26 ; viii. 4,13 ; ix. 11, 53 ; App. iii.

Christs, The, iv. 30 ; vii. 49 ; viii. 12, 15. 16, 27, 45 ; ix. 11, 29.

The Ideal, i. $55 d$; viii. $4,45,51$. Christhood, vii. $43-45$; viii. 18 ; ix. $22,53$.

Christian Belief, i. 44.

Christianity, Pref. iv ; Pref. R.E. li, liii ; vii. 19 ; viii. 49 ; App. iii.

Degradation of, iii. 30 .

Dogmas and Symbols of, Pref. R.E. liv.

Failure of, i. $55 \mathrm{c}$; viii. 26.

Historic, i. 50 ; $55 b$.

Identical with other Systems, Pref. R. E. liv; i. 43-45.

Church, Pref. F.E. ; vi. 2, 27-30; vii. $34-39,50$; ix. 10.

Catholic, Pref. $i v$.

Fathers of, ix. 26.

Lodge, or Mystic Community, vi. 14.

of Christ, v. 46.

Rests on Custom, i. 50.

Churches, Eastern and Western, ix. 43.

Civilisation, Present, vii. 55 .

Clemens, Alex., vi. 8 ; ix. 22.

Clifford, Professor, i. 35, n.

Colleges of Mysteries, i. 44 ; vii. 41 . Common Sense, i. 23. 
Communion, Holy, iv. 36, 37 .

Community, Mystic, vii. 43,44 .

Conjunctions, Planetary, ii. 25.

Conscience, i. 52 ; vi. 27 ; vii. $1,23$.

Consciousness, i. 33 ; v. 2, 3, 7, $12,23,25,31$; vi. 17, 19; vii. $10,14,37$; viii. 5 ; ix. 34 . Point of, v. 30.

Constantine, i. $55^{b}$.

Consummation, v. 34 ; viii. 4 I.

Controls, iii. 20, 48, 59.

Correspondence, Doctrine of, App. i.

Correspondences, i. 10, 14 ; vii. 2, 7 ; ix. 19.

Counterparts, Astral, iii. 7.

Covering Angels, iii. 36.

Creation, i. 29 ; ii. 9 , 10 ; iii. 3 ; v. $4 \mathrm{I}$; vi. 2,8 ; vii. 4,44 ; viii.

5,41 ; ix. 44.

and Redemption, App. i. 33, 34.

Creative Week, vii. 50; viii. 28.

Credo of the Elect, ix. 54.

Creed, Transition of, Pref. R.E. lvii. Cremation, viii. 9.

Cross, i. 56 ; iv. 9, 20 ; vi. 15 ; viii. 53 , App. ii. $3^{8}$.

Fourfold Meaning of, iv. 21.

Prehistoric, on Monuments, iv. 20.

Sign of, in Heaven, iv. 30.

Sun's Equinoctial Passage of

Ecliptic, iv. 20.

Tree of Life, iv. 20.

Why Fourfold, iv. 21.

Crucifixion, i. 49 ; iv. 29, 31 ; vii. 43 ; viii. $7,8,28,37,41,42$.

Mystery of, iv. 22-26, 29.

of God, iv. 35 .

Crustacea, iii. 21.
Curse of Eve, vi. 16, 39 ; vii. 55 .

Cyrus, Pref. F.E. Ixviii.

Dæmon, see Genii.

Daniel, viii. 52 ; ix. 2.

David, Pref. viii; viii. 27, 45 ; ix. 14. Son of, ix. 12.

Death, v. 21 ; App. i. 39-42.

Sting of, v. 34 ; App. i.

Decan, vi. 37.

Deity, Two Modes of, i. 28, 29 ; v. 18 ; ix. 9.

Delphi, ii. 3.

Demeter, vi. 4 ; viii. $28,29,37$.

Depolarisation, vi. 20.

Destiny, ii. 25.

Moral, of Planets, v. 41.

Deucalion and Pyrrha, i. 33 .

Development, i. 32.

Devil, i. 46 ; ii. 6, II ; iii. 9-15, 21 ; iv. 31 ; vii. 29 ; viii. 3 , 13.

No Personal, iii. 9.

Dharmasâstra Sutras, v. 4I, n.

Diana, iv. 14. See also Artemis.

Dimension, Fourth, ii. 34 .

Dionysos, i. 56 ; v. 16.

Dissolution, v. 35 .

Dissolvent, viii. 12.

Divine Impersonal, v. 23.

Dogmas, Christian, Pref. R.E. liv.

Sacerdotal, Pref. F.E. lxiv.

Dragon, Pref. F.E. lxiii, lxiv; vii. 42.

of Apocalypse, vi. 37.

Dryads, iii. 34 .

Dualism, i. 34 ; iii. 29 ; vii. 2, I I,

12 ; viii. 3 ; ix. $42,45$.

of Nature, ii. 42 ; vii. 1 ; ix. 24.

See God, Man. 
Dyaus, Deus, Theos, ii. 42.

Dynamite, i. 55 e.

Eagle, vi. 4 ; viii. 29.

Earth, vi. 19 ; vii. 12, n.

Life, Inequalities of, i. 41 .

Spirits of, iii. 17.

East, viii. 23, 36.

Kings of, viii. 36,53 .

Easter, vi. 31.

Ecclesiasticism, Despair of, ix. 10.

Ecstasy, ix. 34 .

Eden, vi. $6,19,3^{S}$; vii. $5,18,30$, 36 ; ix. 25.

Rivers of, i. 10 ; vi. 6, 7, 14.

Ego, The, Pref. R.E. liii, lvi, lviii; v. $3,12,30,31$.

Noumenal, v. 28.

Egypt, viii. 30, 31, 52 ; ix. 12.

Egyptian Evidences; Thebes, Elephantine, Edfou, Karnak, vi. 13, 18. See Pyramid.

Gospel, ix. 22.

Mysteries, vi. 12, 13.

Eidolon, i. 54 ; iv. 15 ; v. 35.

Eirenicon, Pref. $v$, xliii; Pref. R.E. $l x$; Pref. F.E. $l x x$.

Ejective, v. 31, 33.

Elect, Credo of the, ix. 54.

Electric Current, iii. 22.

Elementals, iii. 5, 17, 20, 34 ; vi. 4, 26.

Elias, viii. 48.

Eliphas Levi, Pref. R.E. $l x$; iv. 12, $\mathrm{n}$; vi. 32.

Elixir of Life, vili. 11.

Elohim, ii. 21,32 ; iii. 37 ; vi. 5 ; ix. $16,44,45$.

El-Shaddai, ii. 42 ; ix. 5, 42.
Elves, iii. 34 .

Emanations, iii. 6 ; iv. 16, 17.

Embalming, viii. 9.

Embryonic Development, v. I 8 .

Emotion and Intellect, ix. 25.

England and the East, viii. 51, 53 .

Enoch, viii. 53.

Enthusiasm, ix. 29, 31, 33-39.

Environment, v. 29.

Epicurus, ix. 39.

Epiphanius, iv. 13.

Epopt, i, 35.

Esau, ii. 39.

Esdras, vi. 10.

Essenism, App. iii.

Esther, vi. 3 I.

Eternal Death, iii. 11 .

Eternal Life, iv. 31 ; vi. 21 ; viii. 41 ; ix. 53.

Ethiopia, Pref. F.E. ; vi. 6.

Eucharistic Wafer, vi. 34 ; viii. 41.

Euphrates, vi. 6 ; viii. 36, 53 .

Eve, Pref. R.E. lix ; v. 10; vi. 15, 16,

$17,19,20,22,23,31$; vii. 20 ,

21 ; viii. 32, 35, 39, 41 ; ix. 20.

Everard, Dr., Pref. R.E. lvii.

Evil, ii. 9, 23 ; vii. 17.

Spirits, iii. 15.

Evolution, i, 32, 40 ; v. 1, 10, 32, 45 ; vi. 14 ; vii. 37 ; viii. 27,32 ,

37,41 ; ix. 53.

Occult Law of, v. 32.

Post-mortem, iii. 19.

Spiritual, i. 8.

Exile, Pref. R.E. lix ; iv. 31.

Existence, Pref. R.E. liii; ii. 29 ;

vi. 35 ; vii. $7,17,37,49$; viii.

5. 43 ; ix. 9,18 .

Previous, and Ezra, vi. 10. 
Exodus, ix. 2.

Experience, ii. IO; viii. 4.

Ezekiel, iii. 5 ; vi. 3,34 ; viii. 36 ; ix. 2.

Ezra, vi. 10.

Faculty of Anna Kingsford, Pref. $x x x i x-x l i i$.

Fairies, iii. 34 .

Faith, i. $5^{1}$; vi. 27. of Christendom, Pref. R.E. liv; i. 55 .

Fall, Pref. R.E. lix ; i. 52 ; iv. 31 ; vi. $7,10,13,29,31$; vii. 1,51 ; viii. I.

Mosaic Account, Allegorical, vi. 8 . of Angels, viii. 5.

Fate, ii. 25.

Finding Christ, i. II ; ii. 47 ; vi. 19. Fire and Motion, ii. 22.

Spirits, iii. I 7 .

Fish, Occult Significance of, viii. 28 ; ix. Io ; App. iii. See also Food.

Five Wounds, iv, 24.

Fixation of the Volatile, iv. $3 \mathrm{I}$; vi. 20 ; vii. 39 ; viii 22.

Flesh, Diet of, Pref. ii, iii, xli; iii. 60 ; iv. $15,17,18$; vi. 24. See also Food.

Flight, Mystic, viii. 52.

Food, vi. 24 ; viii. I4.

Jesus and, App. iii.

Forbidden Fruit, viii. Io.

Force, v. 4 ; vii. 13, 40 ; ix. 44 ; App. i. 2.

Centripetal and Centrifugal, v. 5 .

Form and Character, iii. 2 I.

Free Love, iii. 30.
Gadarene Demoniacs, iii. I5.

Gautama Buddha, i. 38 ; iv. 15 ; vi. 42 ; viii. 48.

Gehenna, vi. 6.

Gehon, vi. 6.

Genealogy, ix. II.

Genesis, vi. 6, 7 ; vii. 32.

by Ezra, not Moses, vi. 10.

Genii, iii. 37, 44-49, 55 .

Loci, iii. 34 .

Ghost, iii. 19 ; v. 36-38.

of Events, i. 16 ; iii. 7 .

Globe, Igneous, v. 24, 26.

Gnosis, Pref. iii, iv, xxxiii, xli; Pref. R.E. li; vi. 9, 25, 26 ; vii. 48 ; viii. 53 ; ix. $7, \mathrm{n}$.

God, ii. $16,29,32$; v. 25,31 ; ix. I, 8, 40, 4I.

Androgynous, ix. 8, $4 \mathrm{I}$.

As Lord, ix. 2-9.

Blood of, viii. 16.

Duality of, ii. 29, 34 ; ix. 45, 50.

God-consciousness, v. 16, 28, 32 .

Immolation of, viii. $4 \mathrm{I}$.

Kingdom of, Pref. R.E. lvii; ii. 32. Macrocosmic and Microcosmic, App. i. 30, 31.

Names of, ii. 42 of Hosts, ii. 41 .

Personal and Impersonal, v. 9.

Spirits of, see Seven.

Vision of, see Sight.

Works of, ii. 32.

God-Man, viii. II .

Gods and Goddesses, ii. 32, 43 . not limited in number, v. 19.

Personality Indefeasible, v. 42.

Golden Age, ii. I8; vi. 14, 16, 24,

$3^{8}$; vii. $40,50,55$. 
Goliath, ix. I4.

Gorgon, see Medusa.

Gospel of Interpretation, Pref. $v$; vii. 53.

Gospels, viii. 24, 28, 29, 32, 42 ; App. ii. 27, 29 ; App. iii. of Love and Force, i. 55e.

Frand Man, ix. 5.

Gravitation, Spiritual, vii. 18.

Great Work, viii. 23.

Gregory of Nazianzen, vi. 8.

Gregory of Nyssa, vi. 8.

Guardian Angel, iii. 29, 37, 46 58:

Guides, iii. 20.

Gulf, Great, iii. 16.

Hayman, Dr., v. 35, n.

Healing Powers, iii. I8.

Heaven, i. 8 ; iv. 16 ; vi. 19.

Hegel, Pref. R. E. lviii.

Hell, iii. 9 ; vi. 21 ; ix. 7.

Hephaistus, Tongs of, ix. 16.

Hera, vii. 42.

Heracles, v. 35 ; vii. 42 ; viii. 19, 22. Ascension of, i. 49.

Heredity, vii. 17.

Heritage of Elect, iv. 25.

Hermes, Pref. F.E. Ixiii; v. 20, 41 ; viii. 12 ; ix. $11,13,15$, 16,17 .

Hermes Trismegistus, i. 36 ; v. 16 , n. Hermetic Philosophy, Pref. iii; Pref. R.E. lu; vii. 3 .

Herod, viii. 31.

Heroes, viii. 18.

Hestia, ii. 13 ; vi. 31 .

Heterisation, Pref. R.E. lvii, lviii.

Hiddekel, vi. 6.

Hierarch, viii. 19, 22, 23.
Hierarchy of Heaven, iii. 37, 60 ; ix. 49.

Hieroglyph, Pref. R.E. lvi ; ii. 46 ; viii. 26.

Hierophant, iii. 53.

Hindu Myths, vi. 12.

Hindustan, viii. 53.

History, see Religion.

Holy City, vi. 24 ; viii. 19.

Holy Family, viii. 52.

Holy Ghost, or Spirit, Pref. R.E. lix ; ix. 42, 43, 44.

Holy of Holies, viii. 28, 48; ix. 49.

Horus, i. 49.

Host, vi. 34.

Hosts, God of, ii. 41 .

Houris, ix. 28.

Human Kingdom, vi. 4.

Humanity, Pref. F.E. $l x i v$; ii. 32 ; vi. 24 ; vii. $11,13,20,50$; viii. $6,47,51,54$; ix. $8,18,22$.

Hydrogen, ii. 20.

Hygieia, vii. 55 .

Iacchos, i. 44 ; v. 40 ; viii. $28,37$. Ideas, ii. 19 ; iv. 16 ; v. 20 ; viii. 3 , 5 ; ix. 50.

Archetypal, v. 21.

Divine, ii. 14.

Religious, i. 54 .

Idolatry, ii. 8 ; iv. 3,31 ; vi. 25,26 :

vii. 6,52 ; viii. 10,26 ; ix. 10.

Ill Living, iii. 45.

Illumination, Pref.; Pref. R.E. Ixi ;

i. 7,35 ; iii. 52, 53 ; App. iii

Image of God, i. 53 ; ii. 11,44 ; v.

18 ; vi. $2,14,24$; vii. $5,26,39$,

51 ; viii. 4,11 ; ix. $8,9,46$, n.,

53. 
Imitation of God, ii. II.

Immaculate Conception, v. 44, 45.

Mother of God, Pref. R.E. lix.

Immanuel, iv. 32.

Immortality, ii. 26 ; vi. 8.

Incantation, iii. 9 ; iv. 7.

Incarnation, Pref. R.E. lix ; iv. $3 \mathrm{I}$;

vi. 31 ; viii. 40 ; ix. 7, n. ; App.

ii. 27.

India, viii. 51, 52 .

Individual, ii. 15 ; vii. 7 ; viii. 3 ; ix. $46, n$.

Individualism, v. 2.

Individuality, v. 5, 32, 43 .

Influx, Divine, i. 8.

Initiate, Initiation, iii. I8; viii. 3 I. App. ii. 3I-38.

Intellect, ix. 25.

Intuition, Pref. xiv; Pref. R.E. lii, liii; Pref. F.E. ; i. 5, 6, 7 ; ii. 38,41 ; v. 33 ; vii. 13,30 ; ix. 17.

a Mode of Mind, i. 5 .

Method of, i. I2, 15.

Irenæus, vi. 8.

Isaac, viii. 52.

Isaiah, viii. 25 ; ix. 2.

Isha, vi. 15, 23.

Isis, ii. 35 ; iii. 42,51 ; iv. 27 ; vi. 18 ; viii. 52 .

Islam, viii. 53 ; ix. 28.

Israel, Pref. F.E. ; vii. 48, 55 ; viii. $30,47,50,52$.

Issa, iv. 27.

Jacob, viii. 52. See also Iacchos.

Jakshas, iv. I2.

Janus Bifrons, i, 2 I.

Jasper, vi. 4.
Jehovah, ii. 42 ; iii. 28 ; vi. 31 ; ix. $5,7,42$.

Jericho, ix. 13.

Jerome, vi. 3, n., 8.

Jerusalem, Pref. F.E.

New, vii. 30 ; viii. 43 .

Jesse, viii. 52.

Jesus, Pref. R.E. $l v$; ii. 46 ; vi. 3 , 42 ; viii. $12,17,24,49,52$; App. ii. 28 ; App. iii.

and Fish-eating and Flesh-eating, App. iii.

Buddha, and Pythagoras, viii. 4851.

Chrestos, iv. 27, 30.

Liberator, viii. 27.

Name, iv. 27.

versus Paul, ix. 22.

Job, Pref. iii, viii ; viii. 52.

John, viii. I2.

the Divine, viii. 29.

Baptist, viii. 38, 49.

Jordan, viii. 39 .

Joseph, as Mind, viii. 30, 31 ; App. ii. 27.

Joshua, ix. 15.

Judaism, i. $55 b$.

Judas, iv. 9; viii 44 .

Julian the Apostate, iv, 14.

Justice, Divine, viii. 2.

Justin Martyr, vi. 8.

Kaabah, vi. I, 2, 3 ; ix. 18.

Kabbala, Pref. R. E., $l x$, lxi ; v. 20 ;

ix. 9, 18, 19, 20, 24.

Kabbalistic Philosophy, Pref. R.E. li; v. 21.

Kalpa, i. 29 ; iv. 35 ; v. 4 I ; vi. 3 I, 34 . 
Kant, Pref. R. E. lvii.

Karma, v. 14, 41.

Karoub Tree, i. 25.

Kelpis, iii. 34 .

Keys of the Kingdom, i. 21.

Kingdom of Heaven, iii. 3 ; iv. 31 ; vi. 26 ; ix. 22, 40. of God, Pref. R.E. lvii.

King's Chamber, v. 22 ; viii. 28.

Kings of East, viii. 36, 53.

Kingsfurd, Anna, Pref.

Knowledge, Self, ii. 3 ; vii. 10.

Koran, vi. I ; ix. 28.

Krishna, i. $3^{8}, 44,49,56$; ii. 46 ; viii. 12, 50 ; ix. 3, I1, 52 .

Kronia, vi. 35.

Lamb of God, iv. 30 ; viii. $4 \mathrm{I}$. Marriage of, vi. 2 ; viii. 41 .

Lares and Penates, iii. 8, 20.

Larvæ, iii. 20.

Last Supper and Passover, App. iii. Law, App. i. 2. and Gospel, ii. 42.

Lazarus, iii. 16 ; viii. 28.

Leibnitz on Reincarnation, i. $3^{8}$.

Leo, vi. 39.

Leo XIII., v. 44 , n. ; vi. 39.

Lethe, iii. 20.

Levi, Tribe of, viii. 45. See Eliphas.

Lewes, G. H., ix. 17, n., 34, n.

Libra, vi. 37 ; ix. 22.

Life, v. 10 ; ix. 43.

Life-process, v. 18.

Light, latent, iii. 24. of Asia, iv. 15.

Light Invisible, ii. 30 ; ix. 45.

Limbo, Limbic, iii. $4,8$.
Lion, vi. 4 ; viii. 29.

Loaves and Fishes, viii. 28 ; App. ii. 39 .

Logos, v. 20 ; viii. 17, 50 ; ix. 23 ,

$24,44,46,50,53$.

Lord, Our, and the Lord, ix. 7, 8.

Lot's Wife, vi. 20.

Love, Divine, iv. 25, 34 ; vii. 13.

Lucretius, ix. 39.

Luke, viii. 29.

Lunar Months, viii. 44.

Maccabees, vi. 11 .

Macrocosm and Microcosm, Pref. R. E. lviii ; i. 10 ; ii. 19, 22, 36, 37 ; iii. $3,3^{8}, 51$; iv. 15,31 ; v. 25 ; vi. 21 ; vii. 5 ; viii. 5 , $36,43,5^{1}$; ix. $9,44$.

Magdalen, viii. 32, 35 ; ix. 13.

Magi, Magian, vii. 48 ; viii. 22, 36, 53.

Magic Number, iii. 4.

Magical Age, vi. 3 ; viii. 19, 3 I.

Magie, la Haute, El. Levi, iv. 12, n.; v. 39.

Magnetic Atmosphere, i. 54 ; ii. 18 ; iii. 18.

Body, iii. 5 .

Factor, ii. 21.

Force, ii. 13.

Maimonides, i. 25 ; vi. 8.

Maitland, Edward, Pref.

Man, ii. $3^{8}$; vii. $5^{1}$; viii. $49,5^{1}$; ix. 38,53 .

as Microcosm, iv. 31 .

Dematerialisation of, i. 14.

Fourfold Nature of, i. 9, 10; vii. 7, 9-14 ; App. i. 16, 19 ; App. iii. 
Man, his Divine Part, i. I3.

his own Creator, ii. 25.

Natural, iii. 3.

of Sin, i. $55 e$; ix. 23.

Regenerate, ii. 46 ; iv. 24 ; v. 44 ; viii. $25-28,30,31,33,38,41$, $45,48,49$; ix. 12 .

Rudimentary, App. i. I9.

Spiritual, iii. 3 .

Manes, or Shades, iii. 7,8 .

Manetho, vi. I3.

Manhood, ii. 38 ; vii. 39.

Manifestation, viii. 5 ; ix. 42,44 . of God, v. 17, 18.

Mark, viii. 29,

Marriage, iii. 55 ; vii. 12.

Divine, vi. 39 ; vii. 50 ; viii. 4 I, 43.

Mary, or Maria, Pref. R.E. lix ; ii. 34,35 ; vi. 19, 23,37 ; viii. 30 , $32,35,39,40$.

Annunciation of, viii. 39 .

Assumption of, v. 43-46.

Materialism, ii. 6, 7 ; ix. 14, 30, $31,35,37,38,39$.

Materialists and Mystics, Pref. ; ix. 35-39.

Matter, i. 28 ; ii. 8,9 ; v. 8 , I I, I2; vii. $15,16,25$; viii. 5 ; ix. 35 .

Antithesis of Spirit, ii. 4.

Dynamic and Static, i. 29.

Dynamic Condition of Substance, i. 28, 29.

Manifestation of Spirit, ii. 9. not evil, is Spirit, ii. 8. not Soul, ii. 2.

Matthew, viii. 29.

Maudsley, Dr., ix. 34, n.
Maut, vi. I 5 .

Maya, vi. 25, 26, 31, 33.

Mecca, vi. I.

Mediator, The Soul as, i. 18, 21 ; vii. 13.

Medium, iii. 23 ; viii. $15,16,18$.

Medusa, Pref. F.E. lxiii, lxiv.

Memory, Intuitional, i. 7,8 ; vi. I0 ; vii. 40.

Recovery of, iii. 52.

Two Kinds of, iii. 50; v. 2, 3 I.

Merkaba, vi. 2 ; ix. 18.

Meru, Mount, vi. 5 .

Messiah, iv. 8 ; viii. $45,47$.

Metallic Region of Planet, ii. 18.

Metempsychosis, iii. 20.

Microcosm, see Macrocosm.

Migration of Cosmic Souls, v. 42.

Milton, iii. 33 ; ix. 27.

Mind, v. 8, 9, 20.

Joseph as, viii. $30,3 \mathrm{I}$.

Miracles, i. 24, 25 ; viii. 28 ; App. ii. 29,36 ; App. iii.

Mirror, Protoplasmic, iii. 7 ; vii. 7 . Mithras, i. $44,49,56$; ii. 46 ; vi.

37 ; viii. $25,50$.

Mohammed, vi. I ; viii. 52.

Molech, iv. I4.

Molecules, i. 28 ; v. 2, 3, 32.

Monad, v. 32.

Dualism of, ii. 29.

Monstrance, vi. 34 .

Moon, The Genius as, iii. 39-47, $51,52$.

The Apocalyptic, vii. 27.

Mormonism, ix. 28.

Moses, iii. 49 ; iv. 7 ; vi. $10-13,15$; viii. 48, 50 ; ix. 2, 9, 24.

Books of, see Pentateuch. 
Mosheim, vi. 8.

Mother, viii. 30, 32, 35, 39, 40 ; ix. 53.

of God, Pref. R.E. of Sorrows, Joys, ii. $3^{6}$.

Motion, ii. 22 ; v. 3 ; vi. 3 I, 33.

Mount, Celestial, The, vi. 5, 36 ; vii. 43-49.

Mysteries, Pref. ; i. 44 ; iv. 31 ; v. 22,46 ; vi. 2 ; vii. 41 ; viii. 28 , 52 ; Secrecy of, iii. 28.

Not Incomprehensible, ix. Io.

Taught Transmigration, i. 35-4I.

Mystery of Godliness, ix. 9, 18.

Mysticism, Pref. vii-ix; ii. 4 ; vii. 10; ix. 29-36.

Mystics, Defined, Pref. vii-ix; v. 28, 29; viii. 25.

and Materialists, ix. 35-39.

Myths, Parabolic in Hebrew Scriptures, vi. 12.

Naiads, iii. 34 .

Naros, vi. 35 .

Nature, iii. 21 ; vii. 51 ; viii. 3.

Nebuchadnezzar, Dream of, vii. 55. Image of, ix. 14.

Necessity, the Will of God, v. 12.

Negation, Pref. F.E. ; ii. 7 ; iv. 28 ; vi. 22.

Neoplatonists, i. 7 ; ix. 34.

Nephesh, i. 40, n. ; v. 35 .

Neshamah, v. 35, 4 I.

Newman, Cardinal, ix. 10, n.

Nicodemus, v. 45.

Night Time of Soul, iii. 31 .

Nirvâna, Pref. R. E. lix ; i. 29 ; ii. 16 ; iii. 29 ; v. 37,43 , n. ; vi. 31 ; viii. $28,43$.
Noah, Daniel, and Job, viii. 52.

No-God, The, ii. 9 ; iii. 10 ; vii. 17.

Nonentity, ii. 6 ; iii. 14 ; v. 28 .

Not-Being, iii. 11 .

Nothing, viii. 5 .

Nous, iii. 55 ; v. 16 ; ix. II.

Now, vii. 4 ; and Within, ix. 54 .

Nucleolus, iii. 57 ; v. 44 ; viii. 29 , $44,51$.

Nucleus, iii. 57 ; v. 4,44 ; viii. 48 .

Nysa-Nissi, ix. 9.

Obelisk, iii. 37.

Objective, Pref. R.E. $l v$; v. 33 .

Oblation of God, iv. 22, 35, 36.

Occult Science, v. I.

Ocean of Infinitude, ii. 34.

Odic, or Astral, ii. 19, 21.

Odysseus, v. 35 .

Olivet, ix. 9.

Olympus, Pref. F.E. ; iv. 35 ; vi. 5.

Only Begotten, viii. 17 ; ix. 5.

Ordeal, iii. 8 ; viii. 22.

Organism, v. 8.

Original, Divine, ix. 36.

Orthodoxies, Pref. F.E. ; ix. 23

Osiris, i. 44,56 ; ii. 46 ; viii. 25 , 50 ; App. ii. 38.

Ovary, vii. 3 .

Ovid, vi. 14, 24.

Ox, Oxen, vi. 4 ; viii. 29, 37 .

Oxygen, ii. 20.

Pallas or Minerva, ii. 35 .

Papias, vi. 8.

Paracelsus, iv. 12.

Paraclete, i. 7 ; viii. 5 I.

Paradise, vi. 2, 6 ; vii. 51 ; ix. 9.

Lost and Regained, vi. 24. 
Parenchyina, v. 39 .

Passion, iv. $3 \mathrm{I}$; vi. 2 ; viii. 7,8 , $28,39,4$ I.

Passion Week, six Days of Creation, iv. 35 .

I'assover and Last Supper, App. iii. Paul, Pref. R.E. liv; iii. 33 ; iv. 9 ; vi. 19,20 ; viii. 27 ; ix. 9 , 19-24; App. iii.

Pearl, viii. 43.

Penance, iii. 8 ; vi. 3 I.

Pentateuch on Sacrifice, iv. 6.

Not by Moses, iv. 7 ; vi. 1 I.

Perceptive Point, v. 30, 33.

Perfect Man, iv, 27, 29.

Perfect Way, Pref. ; Pref. R.E. ; Pref. F.E. ; i. 7 ; ii. 47 ; vi. 24 ; App. iii.

a Divine Revelation, Pref. iii; App. iii.

or whom written, Pref. $i x, x$; Pref. R.E.

and its Critics, App. iii.

History of, Pref.

not Speculation, Pref. xliii, xliv ;

App. iii.

opposed to Idolatry, App. iii.

Purpose of, Pref. $i i$; Pref. F.E. ; App. iii.

Reception of, Pref. $x x x i-x x x v$. Perfection, iii. 54 ; vi. 6 ; vii. 5 ,

45 ; viii. $4,7,8,11,38$.

Mount of, vii. 45,47 ; ix. 9.

Original, viii. 1 .

System of, i. 2 ; ii. $5,7$.

See Christs.

Perisoul, or Astral Body, i. 9 ; ii.

13, 18 ; iii. $4,5$.

Perseus, I'ref. F.E.
Person of Microcosm, vi. 4 ; ix. II. Person in Godhead, ii. 29 ; v. 17.

in Trinity, v. 4 ; ix. 42.

Persona, v. 9.

Personality, i. 32 ; iii. 32 ; v. 9 , 1 I, 12, I7, 42, 43, n. ; App. i. 32-34.

Personation of Spirits, iii. 25.

Peter, vii. 32.

Catholic Tradition, i. 21.

Confession of, i. 20.

Ship of, Pref. xlvii.

Phantasmagoria, iii. 28.

Phantasms, vii. 13.

Phantoms, v. $27,35,36,37$.

Death of, v. 38 .

Pharaoh, vi. 6.

Pharisees, vi. II.

Phenomena and Substance, ii. 5; App. i. 6-10.

Incapable of Self-cognition, v. 3 I.

Philistines, ix. 14 .

Philo, iii. 33 ; ix. 24.

Philosopher's Stone, viii. II ; ix. 14. Phison, vi. 6, 14.

Pillar of Cloud and Fire, ix. 16.

Pindar, ii. 22 ; v. 35 , n.

Plagiarists, Mystics not, ix. 29, 30.

Planes, Pref. R.E. lvi; i. 30 ; iii. 56,57 .

Planet, Consciousness of, v. 17 . Soul of, v. 17, 39 .

Planet, Memory of, i. 16 ; ii. 18 ; v. 16,17 ; vii. 7 .

Astral Counterpart of, v. 39.

Planisphere, Zodiacal, vi. 36.

Plato, i. 38 ; iii. 33 ; vi. 24 ; vii. $41 ;$ ix. $24,25$. 
Plurality of God, ix. 45.

Poet, ii. 27.

Point of Consciousness, Radiant, v. 23-26, 30.

Polarisation, v. II ; viii. Io, 18, 22 ; ix. 49.

Polarities, v. 33 .

Pontius Pilate, iv. 9.

Pope, see Leo.

Popes, Signet of, v. 16, n.

Poseidon, iii. 16 ; ix. 16.

Positive Doctrine, ii. 5.

Possession, iii. 15.

Postel, Pref. R.E. Ixi.

Potency, Divine, ix. 46.

Potentiality of Man, ii. 1, 28, 29 ; iv. 31 ; vii. 10,39 ; viii. 18.

Poverty, viii, 20.

Powers, Four, v. 4.

Pralaya, v. 40.

Prayer, iii. 49.

Prerogative of Man, Revelation, i. 17.

Present Time a New Era, i. 55.

Presiding Spirits, iii. 34.

Priest and Prophet, iv. 7, 10.

Priesthoods, Error of, i. 22 ; iv. 5 ; vi. 28 ; vii. 19.

Principles, Separability of, v. 35.

Endure, App. i. 33.

Prism, iii. 60 ; iv. 25.

Procession of Spirit, iii. 37 ; ix. 45. of Holy Ghost, ix. 43.

Proclus, ix. 17.

Procrustes, Pref. R.E. lviii.

Prodigal Son, ii. 9.

Prometheus, vi. 19.

Prophet, ii. 43 ; iii. 53 ; iv. 7. 10 ; vii. 49.
Propitiation, iv. 9.

Protestantism and Woman, ix. 27.

Protoplast, v. 19.

Psyche, v. 4. 6, I3, 25, 31 .

Detachinent of, v. 34 .

Purgation, v. 13, 37, 35 .

Purgatory, iii. 4, 8, 20.

Purification, iii. 16 ; ix. 53.

Purity, Condition of, as Means to

Salvation, vii. 18.

Pymander, i. 36 ; ix. 53.

Pyramid, iii. 37 ; vi. 2 ; vii. 55 ;

viii. 28 App. ii. 32-34.

Pythagoras, i. 38 ; ii. 46 ; viii. 48,51

Python, ii. 12 ; vi. 36.

Qualification of Writers, i. 4.

Queen's Chamber, viii. 28.

Rabbi Eliezer, i. 25.

Rabbinical Interpretations, vi. 12.

Race, Correspondence of, with Individual, vii. 7 .

Radiant Point, God as, v. 25.

Rahab, viii. 32 ix 13.

Ram, ix. 13, 15 .

Raphael, ix. II.

Reality, Spiritual only, Pref. R.E. lvii, lix ; vii. 10.

Reason, Pure, Pref. F.E. ; i. 23 ; vi. 27.

Reconciliation, iv. 16, 24.

Reconstruction, i. 56.

Redeemers, vii. 49.

Kedemption, Pref. R.E. lix ; ii. 10;

iv. $3^{1}$; vi. $20,3^{1}, 3^{8}$; vii. 26 ;

viii. $2,5,6,7,41$.

Keflection, iii. 33.

Reflective States, iii. 3 I. 
Reflects, iii. 25 ; ix. 7, n.

Reformation, ix. 27.

Refraction, iii. 33 .

Regeneration, iii. 50, 53 ; v. 30 ; vi. 24 ; viii. I2, 3 I, 43 , ix. 7 , n., 53 .

Religion, Pref. R.E., li, liii, lii ; vii. 49 ; viii. 24 ; App. i. 4.

Degenerate, i. $55 f$; vi. 25.

Historic, i. 43.

Keynote of, iv. 4. not Historical, Pref. R.E. ; App. iii.

Presentation of, Pref. R.E. Real, i. 48 ; ii. 12.

Religious Belief, Plane of, Pref. R.E.

Renunciation, viii. $38,50$.

Representative Men, ii. 5 .

Reservation of Jesus, i. 55d.

Rest, or Static Condition, i. 29.

Resurrection, Pref. R.E. lix ; vi. 2 ;

viii. 8, 9, IO, 40, 52 . of Jesus, App. iii.

Resuscitation, viii. 9.

Revealer, i. 7.

Revelation, Book of, vii. 19. See also Apocalypse.

Proper Prerogative of Man, i. 17 ; ii. 12.

Rivers of Paradise, vi. 6, 7, 14.

Rod, viii. 30; ix. 16.

Rosary, viii. 20, 39.

Rosicrucian, iii. 34.

Round Table, viii. 44.

Ruach, Anima Bruta, v. $35,37,38$, 40.

Rudimentary Men, vi, I4; vii. Io.
Sabbath, iii. 54 ; vi. 2, I4, I6, 31 ; vii. 55 ; viii. 28.

Sacerdotal Interpolations, vi. 12.

Sacerdotalism, i. $55^{b}$; vii. 34,41 ; viii. 26.

Sacrament of Eucharist, iv. 36, 37.

Sacramental Host, vi. 34 .

Sacred Books, i. 43 ; iv. 4.

Mysteries, Fourfold, iv. 2.

Sacrifice in Pentateuch, Isaiah, Jeremiah, iv. 6, 7 .

Doctrine of, iv. 16.

Jesus and, iv. 8, 9.

Salamanders, iii. 34 .

Salt, vi. 20 ; viii. Io.

Salvation, Pref. R.E. lvii ; i. 42 ;

ii. I2; iii. II, 22 ; iv. 27,32 ; vii. $4,5,6,18,28$; viii. 27 ; App. iii.

Captain of, viii. 4.

Sangreal, iv. I9; viii. II.

Sapphire, vi. 4.

Sara, viii. 52, n. ; ix. 20, n.

Satan, iii. I3.

Saturn, v. 37.

Saturnalia, vi. 35 .

Saving Faith, its Nature, i. 19.

Saviour, Pref. F.E. ; ii. 46 ; iv. 27 ; vii. 18 ; viii. 18.

Personal, iv. 27.

Scale, iii. 60.

Scandinavian Theology, v. 4 I.

Scheffler, i. 56 ; viii. 35.

Schelling, Pref. R. E. lvi ; iii. 5.

Schwegler, ix. 34 .

Science, i. 5 I.

Scripture, Mystic Sense of, Pref. R.E. $l v$; vii. $3-8$; ix. $7, \mathrm{n}$.

Sea of Bitterness, viii. 32. 
Seasons in Spiritual Life, vii. 50.

Sects of Persia, iv. I 2.

Segregation, v. 2.

Self, viii. 3 ; ix. 34,5 I.

Self-consciousness, v. 28.

Selfhood, Pref. R.E. lvi, lviii; v. 18,43, n., 44 ; viii. 27.

Self-propagation, iii. 32.

Sensation and Knowledge, i. 54 ; ii. 6 ; ix. $3^{8}$.

Sensitive, iii. 19.

Sensitiveness, v. 29.

Separability of Principles, v. 33, 35 .

Septimianus, vi. 35.

Sepulchre, viii. 26.

Seraph, vi. 15, 31, 34 .

Serpent, ii. 42 ; iv. 17,28 ; vi. I3, $15,22,25,34$; vii. 5,26 ;

viii. 39.

Brazen, vi. 15.

Serpents, ix. 10.

Sesha, i. 29.

Seven Hills, vii. 3 I.

Spirits of God, ii. 32 ; ix. 44.

Sex, ii. 41 ; vii. 11,13 ; ix. 8.

Shades, iii. 5, 19, 25.

Shechina, viii. 44.

Shiloh, vi. 39.

Sideral Body, ii. 21.

Sight of God, i. I8; ix. 1, 40, 41, $48,51$.

Sin, v. 14 ; vi. 19, 20 ; vii. 4, 22, 24,51 ; viii. $1,47$.

Wilderness of, vi. 15 .

Sinai, ix. 9.

Sion, vi. 5 ; ix. 9.

Siva, ix. 52.

Six Crowns, viii. 28, 43.

Socrates, Demon of, iii. 44.
Socrates and Re-incarnation, i. $3^{8}$.

Sodium, ii. 35.

Sodom and Gomorrha, vi. 30.

Solar System, Man a, ix. 48 .

Solemnisation, viii. $34,40$.

Solidarity, Law of, App. iii.

Sun, ix. 42.

and Word, i. 30.

of God, viii. 44 ; ix. 5, 42, 53.

of Man, viii. 4, 26 ; ix. 53 .

Sons of God, vi. 14 ; vii. 48.

Sophia, ii. 34 ; vi. 15 ; ix. 24.

Sorcery, iv. 12.

Soul, Pref. R.E. lix; i. 26 ; ii. ; iii. 1 ; iv. 4 ; v. $5,7,10,11$; vi. 4,6 ; vii. $1,6,13,27$; viii.

$1,3$.

and Spirit, v. 5-11.

Astral, v. 39, 41 .

Breath of, iii. 27.

Church and the, Pref. F.E.

Condemnation of, i. 36 .

Evolution of, i. 40 ; ii. 13, 23.

Immortality of, i. 36 ; ii. 13.

Incarnation of, viii. 6 ; App. i. 25.

in Plants and Animals, ii. 23.

its Reflective Power, ii. 45.

Loss of, iii. 22.

Mediation of, i. 18.

Memory of, i. 6 ; iii. 30.

Migration of, i. 36,37 ; ii. 15 ; v. 41 .

Monad of Divine Substance, $i$. 30.

Nephesh, Lowest Mode of, i. 40, n.

Perceptions and Recollections of, Pref. R.E. liii ; iii. 50 ; ix. $3^{8}$. 
Soul, Perfectibility of, i. 8.

Pre-existence of, i. 8.

Previous Incarnations, i. $37,3^{8}$; ii. 24 ; vi. 10.

Progression of, i. 37.

Rational, iii. 55 .

Reality of, Pref. R.E. liii.

Rebirths of, Pref. R.E. liii ; i. 7 .

Redescends, iii. 2 I.

Re-incarnation of, iii. 19.

Returns to New Bodies, i. 39 .

Substance of, i. 8 .

Universal, i. 40 ; ii. 44.

Souls, passing through of, ix. 54 .

Spectral Companion, iv. 12.

Spectrum, ii. 35 .

Spedalieri, Pref. R.E. $l x$.

Spheres, iii. I, 5 ; vi. 34 ; ix. 48 .

Sphinx, i. 41 ; ix. 19.

Spinoza, vi. II ; App. i. 4, 31 .

Spirals, i. 34 .

Spirit and Matter, i. 28 ; no boundary line between, i. 34 ; v. Io,

II ; App. i. 2, 3 I.

and Soul, Difference between, v. 5-II.

Descent of, i. 7 .

Holy, ii. 18 ; iv. 31 ; vi. 22.

Manifestation of, App. i. 34-37. of God, vii. 5, 15, 25, 26 ; viii. 4,5 .

Spirits, iii. I, 23, 32.

Spiritualism, Astral and Celestial,

iii. 24 ; vii. 54 ; App. iii.

and Materialism, ii. 4-12.

Stable, viii. 37.

Star of East, viii. 37 ; ix. 16.

Stephen, ix. 53.
Stigmata, Five Wounds, iv. 24 ; viii. 19.

Stones, i. 33 ; ix. Io, 14.

Subjective, Pref. R.E. lvi; v. 3I, 33 .

Substance, i. 26, 28 ; ii. 2, 29 ; vii.

5, 10, 37 ; ix. 10, 43; App. i. 2.

Celestial, ii. 17.

Divine, i. 30 ; viii. 5,46 ; ix. 46 .

Monads of, i. 30 ; ii. 29 ; ix. 46. of Soul and Deity, i. 30.

Suffering, viii. 4 .

Sufi, i. 7 ; ix. 28.

Sun, ii. 46 ; iii. 52 ; vi. $2,4,15,34$,

37.

Hieroglyph of God, iv. 27.

Sun of the Soul, iv. 27.

Worship of, i. $55 b$.

Sun-gods, ii. 46 .

Superstition, vi. 27.

Swedenborg, Pref.; ix. 6, 7, n ;

App. i. 4 ; App. iii.

Foremost Herald, ix. 7, n.

Symbol of Deity, ii. 41, 42.

Symbols, iv. 31 .

Synagogue, vi. II.

Synthesis, v. 32.

Tabernacle, vi. 5 ; viii. 44,48 ; ix.

I3.

Talents, Parable of, ii. 26.

Talmud, i. 25 ; vi. 10 ; ix. 20, 24.

Temple, vii. 30 .

Services of, iv. 8.

Veil of, viii. 28.

Temptation vi. 2,13 ; viii. 28.

Tennant, viii. 50, n.

Testament, Old and New, iv. 8 ; vii. 6. 
Theckla, ix. 22, n.

Theocracy, v. 23.

Theologia, i. 47.

Theosophical Society, Pref. xiii, n.

Theosophy, v. 22.

Thirteen, iii. 4 ; viii. 44 .

Thirteenth Personage, viii. 44.

Thoth, v. 20; ix. I1, 12, 13. See also Hermes.

Thought, ix. II.

of God, viii. 5 ; ix. 46.

Tides, vii. 50.

Time, the Present, Pref. F.E.

Time, Times, and a Half, viii. 53 .

Tradition, i. $55^{b}$.

Trainer of the Christs, viii. 12 ; ix.

II.

Transfiguration, viii. 48 .

Transmigration of Souls, i. 36 ; v. 41.

Transmigrations many, viii. 18.

Transmutation, iv. 25,27 ; vi. 21 ; viii. 12, 43.

Tree of Divination of Good and Evil, vi. 33.

of Life and Knowledge, vi. 8, $21,25,27,35,39$; vii. 18.

of the Hesperides, vi. 36 .

Trimurti, ix. 52.

Trinity, i. 30 ; v. 4 ; ix. 41, 42, 43, $45,46, \mathrm{n}$.

Trismegistus, i. 36.

Tablet of, why Emerald, v. 16, n.

Trithemius, Pref. R.E. Ixi.

Truth, l'ref. R.E.; Pref. F.E.

Twelve Apostles, viii. 44.

Gates, viii. 19, 43 .

Houses, viii. 43 .

Typhon,|vi. 22.
Ultimates, iii. 2.

Understanding, Pref. ; Pref. F.E. ; ix. $11,13,16$.

Unit and Cipher, ii. 41 ; ix. 42.

Unity, v. 32.

of Soul and Spirit, viii. 3.

Universal Medicine, viii. II.

Universals, Pref. R.E. lvi.

Universe, Consciousness of, v. 17.

Principle of, i. II ; ii. 29 ; ix. 48.

Procession of, viii. 5 .

Soul of, vi. I6.

Utopia, vii. 40.

Vampires, iii. 28.

Vegetable Diet, Pref. ; vi. 24 : viii.

14. See also Flesh, Diet of; and Food.

Vehicles, Pref. R.E. lvi. ; iii. 32, 56 ; v. 22 ; vi. 2.

Veil, ii. 34 ; viii. 28.

Venus, ii. 35 ; vi. 1,2 ; ix. $27, n$.

Vestal Virgins, vi. 31.

Via Dolorosa, iv. 23 ; viii. 21.

Vibration, Universality of, v. 3 .

Vicarious Bloodshed, ix. 24.

Redemption, viii. 2.

Sacrifice, iii. 30 ; ix. 22, 28.

Victories, Our Lady of, ii. 35 .

Virgil, vii. 55.

Virgin, Celestial, vi. 36, 39 .

Cultus of, v. 45.

Mary, ii. 35, 36 .

Soul, vii. 26 ; ix. $13,53$.

Virgo, v. 45 ; ix. 22.

Vishnu, ix. 52.

Vision of Adonai, ix. 47-52.

of the Astrals, iv. 14.

of,the Three Veils, vii. 42. 
Vital Spirits, iv. 12.

Vivisection, Pref. $i i$, iii; iii. 2I, 30 ; vii. 54 ; ix. 17.

Volatilisation of the Fixed, vi. 20.

Water, v. 14 , 16 ; vii. I3, n. ; viii. 28. and the Spirit, v. 45 ; viii. $4,30$.

Waves, Spiritual, vii. 50.

Weigelius, Pref. R.E. Ivii.

Will, v. 12 ; vii. 40.

Central, viii. I, 3, 4 .

Witches, iv. I 2.

Within and Without, iv. 3I, vii. 8, 44 ; viii. $3,15,49$; ix. 9.

Within, Now and, ix. 54 .

Witnesses, Two Apocalyptic, iv. 23 ; vii. 55 ; ix. 19.

Woman, ii. 34,48 ; iii. 28 ; vi. 18 , $3^{8}$; vii. 12, 19, 30, 51, 53 ; viii. $44,49,5 \mathrm{I}$; ix. $20,25,38$.
Woman of Apocalypse, vi. 37.

Soul or Essential, ii. 44.

Temptation of by Serpent, and of Man by Woman, vi. 13.

Word, v. 4 ; vi. 9.

World, Exemplary, v. 21.

Worlds, One Law for all, v. 15.

Yakuts, iv. I2.

Year I881, viii. 47.

Yes, Jesus as the divine, iv. 27.

Yezidis, iv. 12.

Zachariah, iv. 13.

Zeus, Pref. F.F. ; ii. 21, 42 ; vi. 19; vii. 42.

Zodiac, ii. 46 ; vi. 40,41 ; vii. 26 ; viii. 19, 43 ; App. iii.

Zoroaster, i. 44 ; ii. 46 ; viii. 50. 


\section{Anna Kingsford \& Edward Maitland \\ written jointly or separately}

The Perfect Way; or, The Finding of Christ. By Anna (Bonus) Kingsford and Edward Maitland. Fourth Edition, with Illustrations and Additions, edited by Samuel Hopgood Hart. Cloth Covers, price 6s. net; post free, Inland, 6s. 4d. ; Foreign, 6s. 9d.; United States of America, \$1.62. Popular Edition, Paper Covers, price Is. net; post free, Inland, Is. 4 d. ; Foreign, Is. 5 d.; United States of America, 36 cents.

"Clothed with the Sun": being the Book of the Illuminations of Anna (Bonus) Kingsford. Edited by Edward Maitland. Second Edition, edited by Samuel Hopgood Hart. Cloth Covers, price 5s. net; post free, Inland, 5s. 4d. ; Foreign, 5s. 9d. ; United States of America, \$1.40.

The Life of Anna Kingsford. By Edward Maitland. A Second Edition in preparation.

The Story of Anna Kingsford and Edward Maitland, and of the New Gospel of Interpretation. By Edward Maitland. Third and Enlarged Edition, with Portraits, edited by Samuel Hopgood Hart. Cloth Covers, price 3s. 6d. net; post free, Inland, 3s. rod.; Foreign, 4s. ; United States of America, \$r.

The Bible's Own Account of Itself. By EDward MatTland. Second Edition, with Appendix, edited by Samuel Hopgood Hart. Cloth Covers, price rs. 6d. net; post free, Inland, Is. 8d.; Foreign, Is. IId.; United States of America, 50 cents. Paper Covers, price 6d. net; post free, Inland, 7 d. ; Foreign, 7 d. ; United States of America, 15 cents.

Dreams and Dream-Stories. By ANNA (Bonus) Kingsford. Edited by Edward Maitland. Third Edition, edited by Samuel Hopgood Hart. Cloth Covers, price 3s. 6d. net ; post free, Inland, 3s. Iod. ; Foreign, 4s.; United States of America, \$r.

All the above-mentioned books can be furchased from

John M. Watkins, 2l Cecil Court, Charing Cross Rd., London, England 
32 


\section{PLEASE DO NOT REMOVE CARDS OR SLIPS FROM THIS POCKE}

\section{UNIVERSITY OF TORONTO LIBRAF}


